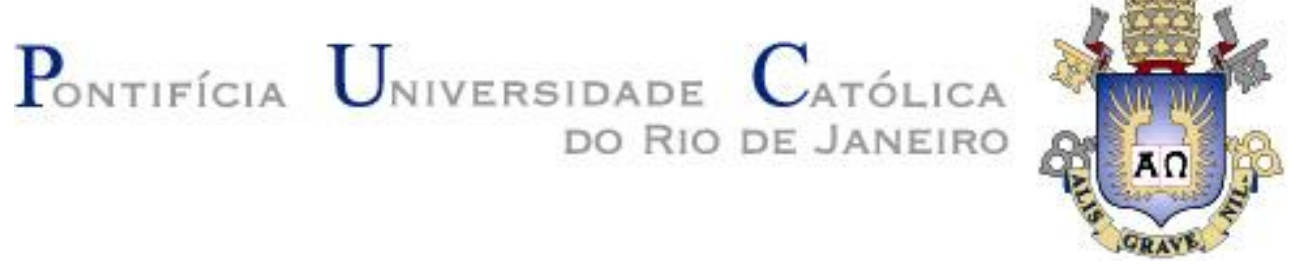

Tânia Maria Couto Maia

\title{
Um discurso e um método \\ Abordagem pragmalinguística do texto de Jo 5,19-47 \\ na perspectiva da unidade de sua comunicação
}

Tese de doutorado

Tese que será apresentada como requisito parcial para obtenção do grau de doutor pelo Programa de Pósgraduação em Teologia da PUC-Rio. Aprovada pela Comissão Examinadora abaixo assinada.

Orientadora: Profa. Maria de Lourdes Correa Lima

Rio de Janeiro

Março de 2014 


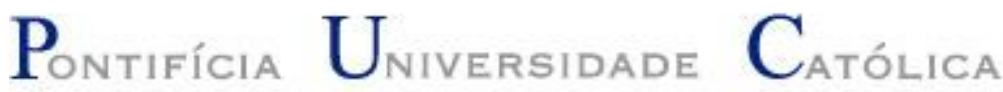

Tânia Maria Couto Maia

Um discurso e um método

Abordagem pragmalinguística do texto de Jo 5,19-47 na perspectiva da unidade de sua comunicação

Tese que será apresentada como requisito parcial para obtenção do grau de doutor pelo Programa de Pósgraduação em Teologia do Departamento de Teologia e Ciências Humanas da PUC-Rio. Aprovada pela Comissão Examinadora abaixo assinada.

\section{Profa. Maria de Lourdes Correa Lima \\ Orientadora \\ Departamento de Teologia - PUC-Rio}

Prof. Isidoro Mazzarolo

Departamento de Teologia - PUC-Rio

Prof. Waldecir Gonzaga

Departamento de Teologia - PUC-Rio

Prof ${ }^{\mathrm{a}}$. Teresa Cristina dos Santos Akil de Oliveira

Faculdade Batista do Rio de Janeiro

Prof. Vicente Artuso

PUCPR

Prof ${ }^{a}$. Denise Berruezo Portinari

Coordenadora Setorial de Pós-Graduação e Pesquisa do Centro

de Teologia e Ciências Humanas - PUC-Rio

Rio de Janeiro, 27 de março de 2014 
Todos os direitos reservados. É proibida a reprodução total ou parcial do trabalho sem autorização da universidade, da autora e do orientador.

Tânia Maria Couto Maia

Bacharelou-se em Teologia no Instituto Teológico-Pastoral do Ceará - ITEP no qual é professora desde 1990. Mestrado em Teologia Biblica na Pontifícia Universidade do Rio de Janeiro em 2009. Participou de vários congressos na área bíblica e escreveu inúmeros artigos em revistas, inclusive na Revista Internacional de Teologia (Concilium 333-2009/5).

Ficha Catalográfica

Maia, Tânia Maria Couto

Um discurso e um método. Abordagem pragmalinguística do texto de Jo 5,19-47 na perspectiva da unidade de sua comunicação / Tânia Maria Couto Maia ; orientadora: Maria de Lourdes Correa Lima. - 2014.

216 f. ; $30 \mathrm{~cm}$

Tese (doutorado)-Pontifícia Universidade Católica do Rio de Janeiro, Departamento de Teologia, 2014.

Inclui bibliografia

1. Teologia - Teses. 2. Pai-Filho. 3. Enviado. 4. Palavra. 5. Crer 6. Testemunho. 6. Julgamento. 7. Vida. 8. Leitor-modelo. 9. Leitor-implícito. I. Lima, Maria de Lourdes Correa. II. Pontifícia Universidade Católica do Rio de Janeiro. Departamento de Teologia. III. Título. 
Em memória do Ronald, filho querido, do mestre-amigo Pe. Luís Gonzaga Uchoa e do saudoso Pastor D. Aloísio Lorscheider que estão na casa do Pai. 


\section{Agradecimentos}

A Deus, que em seu infinito amor enviou seu Filho para que por meio dele recebêssemos "graças sobre graças" (Jo 1,16).

À minha orientadora Professora Maria de Lourdes por sua dedicação, cuidado e seriedade na orientação deste trabalho, especialmente, por ter-me aceito acompanhar em circunstâncias tão exíguas de tempo.

Ao CNPq e à PUC-Rio, pelos auxílios concedidos, de modo especial aos que fazem o Departamento de Teologia Bíblica.

Aos professores da PUC pelos importantes ensinamentos ministrados.

Aos colegas da PUC pelo acolhimento e amizade.

À Faculdade Católica de Fortaleza, todo o meu reconhecimento na pessoa do Pe. Evaristo Marcos pelo apoio e amizade.

A todos os amigos que me estimularam e me ajudaram, entre os quais, o prof. Antonio Brandão.

A minha mãe, aos meus irmãos, e familiares pela força e compreensão.

À minha filha Patrícia pela acolhida generosa e por todo o cuidado que me dedicou durante o meu tempo de estudante no Rio de Janeiro.

À minha querida família sem a qual não teria sido possível realizar esta Tese, especialmente, ao meu muito querido e amado Mairan que, juntamente com meus filhos Mairan Júnior, Cristiane e Gerson, Patrícia, Roger e Alessandra e os diletíssimos netos Luís Henrique, Júlia, Maria Clara e Maria Eduarda, muito contribuíram para que eu me dedicasse com exclusividade a este objetivo. 


\section{Resumo}

Maia, Tânia Maria Couto; Lima, Maria de Lourdes Correa. Um discurso e um método. Abordagem pragmalinguística do texto de Jo 5,19-47 na perspectiva da unidade de sua comunicação. Rio de Janeiro, 2014. 216 p. Tese de Doutorado - Departamento de Teologia. Pontifícia Universidade Católica do Rio de Janeiro.

O trabalho tem como objetivo a compreensão do texto discursivo de Jo 5,147, como uma unidade temática, a partir da perspectiva de seu caráter comunicativo. O texto de Jo 5,19-47 não tem recebido o tratamento requerido no contexto do quarto evangelho. Surge daí a necessidade de ser investigado a partir de uma nova abordagem. A escolha de uma proposta metodológica de aproximação ao texto bíblico como literatura levou a tomar como instrumento de mediação a pragmalinguística em sua vertente comunicativa. O discurso de Jo 5,19-47, com sua afirmação da unidade de ação do Pai e do Filho, testemunhada por sua Palavra de vida eterna (v. 24), é de máxima importância para toda a teologia do Evangelho, não só por oferecer o substrato teológico que sustentará o desenvolvimento progressivo da doutrina da teologia da encarnação, mas também porque é o texto que, em larga escala, oferece ao leitor a chave da compreensão do mistério da filiação divina para sua confissão de fé em Jesus como "Messias e Filho de Deus" (Jo 20,31).

\section{Palavras-chave}

A relação Pai - Filho; enviado; Palavra; crer; obras; testemunho; carne; leitor-modelo; leitor implícito. 


\section{Abstract}

Maia, Tânia Maria Couto; Lima, Maria de Lourdes Correa (Advisor). A discourse and a method. A pragmalinguistic approach to the text of John 5, 19-47 from the perspective of the unity of its communication. Rio de Janeiro, 2014. 216 p. Doctorate Thesis - Departamento de Teologia da Pontifícia Universidade Católica do Rio de Janeiro..

This work aims to attain understanding of the discursive text of John 5, 1947 as a thematic unity from the perspective of its communicative aspect. The text of John 5, 19-47 has not been receiving proper treatment in the context of the Fourth Gospel. Thus the need to investigate it under a new approach. The choice of a methodological proposal to approach the biblical text as literature led to the use of the communicative aspect of the pragmalinguistic method as the instrument of mediation. The discourse in John 5, 19-47, which affirms the unity of action between the Father and the Son, testified by His Word of eternal life (verse 24), is of the utmost importance for the theology of the Gospel. It not only provides the theological substrate that will support the continuous development of the doctrine for the theology of Incarnation, but it also offers the reader the key to broadly understanding the mystery of divine sonship for his/her confession of Jesus as the "Messiah and Son of God" (Jo 20,31).

\section{Keywords}

The Father - Son relation; sent; Word; believe; works; testimony; flesh; judgment; model-reader; implied reader. 


\section{Sumário}

1. Introdução

1.1. A problemática que envolve o texto de Jo 5,19-47 13

$\begin{array}{ll}\text { 1.2. Metodologia } & 15\end{array}$

$\begin{array}{ll}\text { 1.3. Plano do trabalho } & 18\end{array}$

2. Principais questões referentes ao capítulo 5 do Evangelho de João 20

2.1. O capítulo 5 e suas peculiaridades 20

2.2. A posição de Jo 5 no contexto do Evangelho 21

2.3. A identificação da "festa" de Jo 5,1 27

2.4. Questões referentes ao discurso de Jo 5,19-47 33

2.4.1. A estrutura literária do discurso 5,19-47 33

2.4.2. A unidade temática 35

2.5. Conclusão 36

3. Eixo metodológico $\quad 38$

3.1. Pré-compreensão metodológica 38

$\begin{array}{ll}\text { 3.2. Perguntas fundamentais } & 38\end{array}$

3.3. O percurso metodológico 43

3.3.1. A natureza da categoria "discurso" 44

3.3.2. Unidade, completude, coesão e coerência do "discurso" 45

3.3.3. Atividades da ação comunicativa do discurso 5

3.4. Conclusão $\quad 58$

4. O texto de Jo 5,19-47 em seus aspectos formais 60

4.1. Tradução, crítica textual e delimitação do texto 60

4.1.1. Tradução do texto de Jo 5,19-47 60

4.1.2. Notas de crítica textual $\quad 65$

4.1.3. Delimitação do discurso de Jo 5,19-47 67

4.2. A Coesão do texto $\quad 70$

4.2.1. A coesão do vocabulário de Jo 5,19-47 70

4.2.2. Aspectos sintáticos do texto de Jo 5,19-47 75

4.2.3. A coesão remissiva e/ ou referencial 83

4.2.4. A coesão sequencial $\quad 88$

4.3. A coerência textual 91

4.3.1. Fatores de coerência textual $\quad 91$

$\begin{array}{lr}\text { 4.3.2. A coerência pragmática } & 100\end{array}$

$\begin{array}{ll}\text { 4.4. Conclusão } & 107\end{array}$

5. O texto de Jo 5,19-47 e seus motivos 108

$\begin{array}{ll}\text { 5.1. Identificação dos motivos } & 108\end{array}$

5.1.1. A revelação da relação entre o Pai e o Filho na obra da salvação
(vv. 19-23). 
5.1.2. O caráter revelador da Palavra do "Enviado" portadora do dom da vida eterna (v. 24).

5.1.3. As duas dimensões do acontecimento do envio do Filho (vv. 25-29). 113

5.1.4. A autorrevelação da pessoa do "Filho", do "Enviado" e do "Filho do Homem" (v. 30).

5.1.5. A legitimação da reivindicação do Filho (vv. 31-39). 115

$\begin{array}{ll}\text { 5.1.6. Jesus, o Filho, o hermeneuta da Palavra das Escrituras (vv. 40-47). } 116 & 116\end{array}$

5.2. Semântica dos motivos

5.2.1. A semântica do primeiro motivo (vv. 19-23) 117

$\begin{array}{ll}\text { 5.2.2. A semântica do segundo motivo (v. 24) } & 128\end{array}$

5.2.3. A semântica do terceiro motivo (vv. 25-29) 132

5.2.4. A semântica do quarto motivo (v. 30) 136

5.2.5. A semântica do quinto motivo (vv. 31-39) 138

5.2.6. A semântica do sexto motivo (vv. 40-47) 142

5.3. A sequência estratégica dos motivos 146

5.3.1. $1^{\circ}$ Momento (vv. 19-23) 146

$\begin{array}{ll}\text { 5.3.2. } 2^{\circ} \text { Momento (v. 24) } & 147\end{array}$

$\begin{array}{ll}\text { 5.3.3. } 3^{\circ} \text { Momento (vv. 25-29) } & 148\end{array}$

5.3.4. $4^{\circ}$ Momento (v. 30) 149

$\begin{array}{ll}\text { 5.3.5. } 5^{\mathrm{o}} \text { Momento (vv. 31-39) } & 150\end{array}$

$\begin{array}{lr}\text { 5.3.6. } 6^{\circ} \text { Momento (vv. 40-47) } & 150\end{array}$

5.4. Síntese dos motivos 151

6. O tema unificador do discurso de Jo 5,19-47 e sua relevância no contexto $\begin{array}{ll}\text { do Evangelho } & 153\end{array}$

6.1. A função pragmática do discurso 153

6.1.1. A relação locutor/interlocutores $\quad 154$

$\begin{array}{ll}\text { 6.1.2. A relação autor/leitor } & 164\end{array}$

6.2. O tema do discurso de Jo 5,19-47: "A Palavra de Jesus testemunha a $\begin{array}{ll}\text { unidade do Filho com o Pai". } & 167\end{array}$

6.3. Relação do discurso com o texto narrativo (5,1-18) 171

6.3.1. O discurso e o texto narrativo 171

6.3.2. O discurso e as questões do texto narrativo 174

6.4. Relação do capítulo 5 com o contexto próximo do Evangelho 179

6.5. Relação do discurso com o contexto do Livro dos Sinais 182

6.6. A função do discurso no contexto global do Evangelho 187

$\begin{array}{ll}\text { 7. Considerações conclusivas } & 193\end{array}$

$\begin{array}{ll}\text { 8. Referências bibliográficas } & 200\end{array}$

9. Anexo 


\section{Abreviaturas}

\begin{tabular}{|c|c|}
\hline $\mathrm{ABD}$ & Anchor Bible Dictionary \\
\hline AnBib & Analecta Biblica \\
\hline $\mathrm{Bib}$ & Bíblica \\
\hline BAC & Biblioteca de Autores Cristãos \\
\hline $\mathrm{BVC}$ & Bible et Vie Chrétienne \\
\hline CBLA & Comentario Bíblico LatinoAmericano \\
\hline CBI & Comentario Bíblico Internacinal \\
\hline CBQ & Catholic Biblical Quarterly \\
\hline CNT & Commentaire du Nouveau Testament \\
\hline 6QDC & Qumran 6, Documento de Damasco \\
\hline DENT & Diccionario Exegético del Nuevo Testamento \\
\hline DGNT & Dicionário do Grego do Novo Testamento \\
\hline DTNT & Diccionaire Teológico del Nuevo Testamento \\
\hline DITNT & Dicionário Internacional de Teologia do Novo Testamento \\
\hline DTB & Dicionário de Teologia Bíblica \\
\hline $\mathrm{DBU}$ & Dicionário Bíblico Universal \\
\hline DTMAT & Diccionario Teologico Manual del AT \\
\hline ETR & Études Théologiques et Religieuses \\
\hline ExR & Exodus Rabbah (Midrash) \\
\hline GCB & Grande Comentário Bíblico \\
\hline GLNT & Grande Lessico del Nuovo Testamento \\
\hline GenR & Genesis Rabbah (Midrash) \\
\hline JSNT & Journal for the Study of the New Testement \\
\hline
\end{tabular}


JSOT Journal for the Study of the Old Testament

LXX Septuaginta

NCBC New Century Bible Commentary

NTG Novum Testamentum Graece

NGCB Nuovo Grande Comentário Bíblico

$\mathrm{P}^{66} \quad$ Papiro Bodmer II do início do ano 200

$\mathrm{P}^{75} \quad$ Papiro grego do início do século III

PCB Pontifícia Comissão Bíblica

PG Migne Patrologia (série grega)

QpNah Qumran Pesher de Nahum

RB Revue Biblique

RevSR Revue des Sciences Religieuses

RIBLA Revista de Interpretação Bíblica Latino-Americana

RivBib Rivista Bíblica

RHPhR Revue d'Histoire et de Philosophie Religieuses

RThPh Revue de Théologie et de Philosophie

ThWNT Theologisques Wörterbuch zum Neuen Testament

TU Texte und Untersuchungen zur Geschichte der altchristlichen Literatur

VTB Vocabulário de Teologia Bíblica

WCB Word Biblical Commentary

WUNT Wissenschaftliche Untersuchungen zum Neuen Testament 
Ninguém jamais viu a Deus: o Filho unigênito, que está no seio do Pai, este o deu a conhecer. Jo 1,18 


\section{Introdução}

\section{1.}

\section{A problemática que envolve o texto de Jo 5,19-47}

Após abertos diversos caminhos para a aplicação do criticismo literário ao texto bíblico, estudiosos da Bíblia ${ }^{1}$ não cessaram de propor novas leituras que comprovassem, cada vez melhor, sua eficácia interpretativa. Visando a esse objetivo, sugerem métodos que priorizem técnicas literárias de análise dos textos bíblicos, de forma a oferecer a possibilidade de se "ler o texto bíblico como o autor quis que seus leitores o lessem" "2. É dentro desse espírito que se encontra a motivação para o estudo do texto de Jo 5,19-47, objeto desta tese ${ }^{3}$. Esse texto de Jo 5,19-47 tem apresentado problemas quanto à sua interpretação a qual leva a supor que exista um problema de comunicação entre o texto e o leitor, já que está em causa a coerência interna do texto e sua relação com outros textos do Evangelho. Essa suposição merece, portanto, ser investigada.

Pesquisando os grandes comentários exegéticos ${ }^{4}$ sobre o Evangelho de João, constata-se que o capítulo 5 é muito menos frequentado do que as outras páginas

\footnotetext{
${ }^{1}$ Cf. CULPEPPER, A. R., Anatomy of the Fourth Gospel A Study in Literary design, Filadelfia: Fortress Press, 1987. Cf. SKA, J. L., Our Fathers Have Told Us. Introduction to the Analysis of Hebrew Narratives, Subsidia biblica, n. 13, Roma: Pontificio Istituto Biblico, 2000. Cf. MARGUERAT, D.; BOURQUIN, Y., Para ler as narrativas bíblicas, São Paulo: Loyola, 2009.

${ }^{2}$ CULPEPPER, A. R., op. cit., p. ix do Prefácio à obra; DIAS DA SILVA, C. M., Leia a Bíblia como literatura, São Paulo: Loyola, 2007.

${ }^{3}$ Este trabalho não abordará questões introdutórias ao Evangelho de João, nem aos seus complexos problemas redacionais e de autoria. Estes foram tratados em minha dissertação de mestrado: "Ex 33,18-23 e Jo 1,14-18: Um Estudo Intertextual na Perspectiva de um Diálogo Semântico Teológico". Apresentada em março de 2009, na PUC-Rio.

${ }^{4}$ Cf. BULTMANN, R., The Gospel of John. A Commentary, Oxford: [s.n.], 1971, p. 209; SCHNACKENBURG, R., El Evangelio según San Juan, v. 2, Salamanca: Herder, 1980, p. 24; BOISMARD, M.-É.; LAMOUILLE, A., L'Évangile de Jean, v. 3, Paris: Éditions du Cerf, 1978, p. 9; GUILDING, A., The Fourth Gospel and Jewish Worship, Oxford: At The Clarendon Press, 1960, p. 45 et seq; LINDARS, B., The Gospel of John, NCBC, London: Marshall, Morgan \& Scott, 1981, p. 50; BLANK, J., O Evangelho segundo João, v. 4/1b, Petrópolis: Vozes, 1991, p. 62; SCHELKLE, K. H., Teologia do Novo Testamento, v. 2, São Paulo: Loyola, 1977, p. 80; BROWN, R., El Evangelio según San Juan, v. 1, Madrid: Cristiandad, 1979, p. 414; LÉONDUFOUR, X., Leitura do Evangelho segundo João, v. 2, São Paulo: Loyola, 1996, p. 16; ZUMSTEIN, J., O Evangelho segundo João, In MARGUERAT, D. (Org.)., Novo Testamento, história, escritura e teologia, São Paulo: Loyola, 2009, p. 443; CASALEGNO, A., Para que contemplem a minha glória. Introdução à teologia do Evangelho de João, São Paulo: Loyola, 2009,
} 
desse Evangelho ${ }^{5}$. A atenção de renomados estudiosos, desde a mais alta antiguidade até os dias de hoje ${ }^{6}$, tem se concentrado em alguns "problemas pontuais" que, além de se repetirem, ainda divergem, quais sejam: a) o que se refere à posição do capítulo 5,1-47 no Evangelho; b) o da identificação da "festa dos judeus" $(5,1)$; e c) o que se refere à questão da falta de unidade literária e da atribuição de grande diversidade temática ao texto do discurso de Jo 5,19-47.

O que surpreende nos atuais comentários ao texto de Jo 5,1-47, segundo a pesquisa bibliográfica realizada no capítulo II deste estudo, é a considerável diversidade de opiniões ainda existente a respeito desses determinados problemas, o que é indício de que persiste, entre os estudiosos, um desacordo, o qual se reflete, sobremaneira, na forma como o texto é lido. Uma vez que as duas primeiras questões - a do deslocamento do capítulo e a da identificação da festa inominada de Jo 5,1 - têm ocupado considerável espaço nos comentários exegéticos desse capítulo, e pelo fato de não haver uma definição clara quanto ao problema da fragmentação e diversidade temática do texto discursivo de 5,19-47, e de sua importância no Evangelho, há lugar para um estudo que privilegie outra forma de abordar o referido discurso, de modo a elucidar pontos discutidos na história da mencionada pesquisa.

Ao transformar em matéria de investigação de um trabalho científico o texto de Jo 5,19-47, este estudo quer propor uma retomada da questão da unidade literária e temática do discurso, a partir de uma proposta metodológica que privilegie o texto em si, isto é, o que ele quer comunicar. Não pretende apresentar soluções, mas experimentar e explorar novas vias que lancem luz sobre o sentido do texto. Esta investigação deverá ter como instrumento de mediação um método que favoreça um novo olhar sobre o texto. Por conseguinte, essa leitura requer uma nova forma de aproximação ao texto de Jo 5,19-47, objetivando contribuir ou até ampliar os resultados obtidos até agora. Isso induz a ponderar "os problemas clássicos" referentes a esse texto, a partir de um instrumental que priorize o acesso

p. 98; PERKINS, P., Il Vangelo Secondo Giovanni In BROWN, R. E.; FITZMYER, J. A.; MURPHY, R. F., Nuovo Commentario Bíblico, [S.I]: Queriniana, 2002, p. 1235 e outros.

${ }^{5}$ Cf. LÉON-DUFOUR, X., op. cit., p. 17. Esse texto também está ausente do calendário litúrgico nos domingos, anos A-B-C.

${ }^{6}$ Cf. ÉPHREM DE NISIBE, Commentaire de l'Évangile Concordant ou Diatessaron. Tradução de Syriaque et de L'Arménien, Sources Chrétiennes, n. 121, Paris: Les Éditions Du Cerf, 1966, p. 23. 
às estratégias literárias ${ }^{7}$, usadas pelo autor em seu processo comunicativo. Consequentemente, a escolha de uma proposta metodológica de aproximação literária ao texto bíblico comporta necessariamente um mergulho profundo na análise dos mecanismos internos de constituição do sentido do referido texto. Sem dúvida, essa postura supõe que essa busca ofereça elementos para uma consideração do texto em uma situação comunicativa e para uma resposta aos desafios de uma moderna hermenêutica.

\section{2. \\ Metodologia}

Os estudos referentes ao capítulo 5 do Evangelho de João demonstram o predomínio da apreciação histórico-crítica. Diante de tal situação se impõe uma reflexão que não contemple primeiramente as questões particulares, as quais nos últimos decênios absorveram muitos desses estudos ${ }^{8}$, mas, antes, a própria metodologia utilizada na aproximação ao texto bíblico como literatura 9 .

A hipótese de partida é que é possível ler o texto de Jo 5,19-47, não como um documento que dá acesso a uma história passada, que deve ser reconstituída (hipótese do texto-fonte), da qual se possa extrair o suporte teológico, ali veiculado, nem como um conjunto de temas agrupados no capítulo 5, mas como um "discurso", uma obra literária. A linguística textual vem postulando que todo texto constitui uma proposta de sentidos múltiplos e não de um único sentido, e todo e qualquer texto é plurilinear em sua construção ${ }^{10}$. Os textos deixam de ser

\footnotetext{
${ }^{7}$ Por estratégias literárias aqui se entende as engenhosas regras de composição construídas pelo autor, dispostas diretamente nos textos, para orientar a atenção do leitor e guiá-lo na compreensão da história. É a arquitetura oculta dos textos. Do ponto de vista pragmático, Massimo Grilli entende por estratégia textual comunicativa a combinação, a ordem e a hierarquia de todos os elementos linguísticos do enunciado. Cf. GRILLI, M., Comunicação e pragmática. Disponível em: http://www.evangeliumetcultura.org/IT/Comunicazione\%20e\%2 Pragmatica. php. Acessado em 14 de maio de 2012.

${ }^{8}$ Tais como: aspectos redacionais, a composição do texto, sua autoria, suas fontes, glosas, repetições, duplicações, contradições, incompletude etc.

9 A ideia de literatura resiste ao rigor de uma conceituação. Foge ao propósito deste trabalho rastrear tal percurso. Porém, segundo Aristóteles, a "literatura é a arte da palavra". Se a "literatura" é uma "arte", então ela é um meio de comunicação de tipo especial e envolve uma linguagem também especial, portanto, "arte literária". Cf. PROENÇA, D. F., A linguagem literária, São Paulo: Ática, 2007, pp. 8; 41.

${ }^{10}$ Segundo a linguista Ingedore Koch "um texto não envelhece, é um bem precioso, deve sempre ser revisitado, pois sempre tem algo a dizer; é como um 'iceberg', que se encontra para sempre escondido e seu sentido mais profundo está à espera de um caçador de sentidos". [...] "E pergunta: Quais as condições e pressuposições que regulam essa procura? Como, em suma, agimos ou
} 
vistos como produtos acabados, passando a ser considerados elementos constitutivos de uma atividade complexa, como instrumentos de realizações de intenções comunicativas e sociais do falante ${ }^{11}$.

O método histórico-crítico continua, segundo o Documento da Pontifícia Comissão Bíblica ${ }^{12}$, “indispensável para o estudo científico do sentido dos textos antigos" e "contribuiu para a produção de obras de exegese e de teologia bíblica de grande valor"13. No entanto, segundo o mesmo documento, "manifesta limites, pois ele se restringe à procura do sentido do texto bíblico nas circunstâncias históricas de sua produção, e não se interessa pelas outras potencialidades de sentido que se manifestaram no decorrer das épocas posteriores da revelação bíblica e da história da Igreja"14.

Ultimamente muitos estudos bíblicos ${ }^{15}$ utilizam métodos que partem da consideração dos textos sob seu aspecto comunicativo ${ }^{16}$. Isto foi particularmente sistematizado na chamada análise pragmalinguística, uma metodologia utilizada na aproximação ao texto bíblico como literatura. Instala-se, pois, no presente estudo, uma confiança na possibilidade que tem o método da pragmalinguística ${ }^{17}$ de esclarecer algumas das tensões internas do texto em análise.

Sobre a aplicação da metodologia pragmalinguística à Bíblia, assim se manifesta Mora Paz:

Os métodos de linguística textual podem respaldar a exegese histórico-crítica e remeter a aspectos do texto, com frequência, negligenciados, que realmente deviam ter sido observados. [...] Pois bem, também se exige uma consideração mais vigorosa dos modelos linguísticos para conhecer o aspecto funcional de cada parte do texto e de sua totalidade. Não só o "significado", mas também a intenção de

deveríamos agir nessa busca?" Cf. KOCH, I. V., Desvendando os segredos do texto, São Paulo, 2011, pp. 67; 23.

${ }^{11}$ Id., Introdução à linguística textual, São Paulo: Martins Fontes, 2009, p. 14.

${ }^{12}$ Cf. PCB., A interpretação da Bíblia na Igreja, São Paulo: Paulinas, 1994, p. 37.

${ }^{13}$ Cf. Ibid., p. 44.

${ }^{14}$ Cf. Ibid., pp. 44-45.

${ }^{15}$ Cf. ZABATIERO, J-P. T.; LEONEL, J., Bíblia, literatura e linguagem, São Paulo: Paulus, 2011, p. 28 et seq.

${ }^{16}$ NAY, R., Jahweh im Dialog Kommunikationsanalytische Untersuchung von Ez 14,1-11 unter Berücksichtigung des Dialogischen Rahmens in Ez 8-11 und Ez 20, AnBib 141, Roma, 1999, p. 13.

17 "O termo pragmática (em grego pragma ação), segundo Grilli, foi empregado, pela primeira vez, por dois filósofos da linguagem Morris e Peirce, ao fim dos anos trinta e início dos anos quarenta. Mas foi a descoberta da categoria dos "atos linguísticos" que conferiu à pragmática uma importância específica no interior do processo comunicativo. O inglês J. L. Austin junto com Searle e Grice e mais alguns estudiosos deram um maior influxo à pragmática moderna". Cf. GRILLI, M. Comunicação e pragmática. Disponível em: http://www.evangeliu metcultura.org/IT/Comunicazione\%20e\%2Pragmatica. php. Acessado em 14 de maio de 2012. 
conduzir a ação têm que ser explicados exatamente. Do mesmo modo deve-se ficar atento à influência do ouvinte na gênese do texto ${ }^{18}$.

A metodologia pragmalinguística provê o intérprete de uma especial sensibilidade que o ajuda a considerar o texto sob um ponto de vista diverso daquele adotado tradicionalmente no método histórico-crítico, inclusive ao tratar da mesma temática. A aplicação de perspectivas diversas, visando enriquecer a solução interpretativa, encontra aqui seu lugar. Importa indagar o texto em sua totalidade, na base da lógica e da dinâmica, que diferencia todo processo comunicativo. Tal forma de abordar o texto implica naturalmente numa investigação de natureza literária.

O que se busca ao empreender uma análise pragmalinguística é tornar explícitos mecanismos implícitos de estruturação e de interpretação do texto em estudo. Precisam ser consideradas, entre outras, questões como: a concepção de texto que subjaz na definição de sua estrutura e de seus respectivos tipos (macro e micro; superficial e profunda); o modo como o autor estrutura seu texto e realiza seus propósitos comunicativos ${ }^{19}$; a condição e a expectativa do leitor implícito e também do atual, no processo de interpretação. Também sua relação com o texto narrativo $(5,1-18)^{20}$, com o contexto próximo e com o Livro dos Sinais, e a consideração da função discursiva do texto de Jo 5,19-47 no contexto global do Evangelho, ampliarão os resultados da análise.

A análise pragmalinguística se detém no estudo dos elementos de comunicação, pertencentes à esfera do discurso. Trata-se de compreender o sentido de um texto como um sentido da situação na qual ele funciona: na situação de um diálogo, testemunhada no texto considerado em seu conjunto. Portanto, trata-se de entender o acontecimento tal qual aparece no texto. Não se pode,

\footnotetext{
${ }^{18}$ MORA PAZ, C. et al., Lectura pragmalingüística de la Biblia, teoría y aplicación, Estella (Navarra): Verbo Divino, 1999, p. 24.

${ }^{19}$ Sabe-se que o texto joanino (mas não só ele) pode ser lido em vários níveis redacionais: no nível da vida de Jesus, no da vida da comunidade que fez a experiência e nos distintos estratos das redações finais. Mas não é destes níveis que aqui se fala. É de um método de linguística textual que permite descrever a geração, a interpretação e a análise de textos, desde a estrutura prélinguística até sua manifestação superficial. Segundo Fiorin o percurso gerativo de sentidos é uma sucessão de patamares. Os níveis do percurso são o profundo ou o fundamental, o narrativodiscursivo e o nível da manifestação. Cf. FIORIN, J. L., Elementos de análise do discurso, São Paulo: Contexto, 2011, pp. 21; 41; 44.

${ }^{20}$ A partir do capítulo 5, os sinais de Jesus, suas curas, são interpretados pelos discursos ou viceversa (5,1-18; 5,19-47; 6,1-15; 6,16-21 e o discurso do Maná vv. 22-58; o capítulo 9 e o 11). Todos eles ligados às festas mencionadas, com exceção do capítulo 5, que não identifica a festa $(5,1)$.
} 
contudo, estudar a "realidade em si mesma", sem considerar a "realidade no texto": esta é um espelho da "realidade em si mesma" e geralmente o seu único testemunho $^{21}$.

Consoante Reto $\mathrm{Nay}^{22}$, duas importantes vantagens dessa abordagem podem ser apresentadas: a) evita a desintegração do texto, pois ele é considerado dentro de um contexto de diálogo mais amplo, que lhe dá unidade; b) a interpretação do texto passa a considerar como ponto central o seu conteúdo, e só pode ser realizada sendo considerados todos os elementos do texto.

\section{3.}

\section{Plano do trabalho}

O presente trabalho está estruturado em duas partes. A primeira parte, constituída por dois capítulos (II e III), tem por função introduzir tanto a questão na qual se radica o objeto deste estudo, quanto o eixo metodológico que vai orientá-lo e regulá-lo. Os capítulos que constituem essa parte da obra procuram orientar o leitor, no sentido de fazê-lo, em primeiro lugar, apropriar-se da problemática que envolve três das questões mais apontadas - quando se comenta o capítulo 5 do Evangelho de João - e que estão relacionadas, direta ou indiretamente, com o texto discursivo (vv. 19-47), por meio de uma pesquisa bibliográfica apresentada em um capítulo próprio, o segundo. Nesse ponto procura-se, apenas, identificar o tratamento dispensado por eminentes exegetas joaninos a tais questões. E em segundo lugar, traçar no capítulo terceiro, por meio de uma detalhada demonstração da metodologia pragmalinguística, o percurso da perspectiva teórica a ser aplicada na nova proposta de leitura sincrônica do texto em estudo.

A segunda parte, estruturada em três capítulos (IV, V, VI), trata da aplicação da metodologia pragmalinguística ao texto de Jo 5,19-47. O capítulo quarto ocupa-se da abordagem do texto em seus aspectos formais, os quais permitem analisar os elementos linguísticos essenciais que, segundo a pragamalinguística, constroem e sustentam a arquitetura unitária do texto, tais como a coesão e a coerência, materializando, assim, a perspectiva teórica apresentada no capítulo terceiro. Ao quinto capítulo está reservada a reflexão sobre o sentido do discurso,

\footnotetext{
${ }^{21}$ NAY, R., Jahweh im Dialog, pp. 14-15.

${ }^{22}$ Ibid., p. 13.
} 
que procurará apresentar e analisar os elementos constituintes dos motivos que tecem a temática central do texto - e que só será possível graças aos momentos anteriores que concentram aspectos particulares do discurso, bem como às possibilidades de leituras instigadas pelas diversas etapas metodológicas.

No capítulo sexto, procura-se identificar a tese principal sobre a qual versa o texto, que é o "tema" unificador do discurso e, consequentemente, seu verdadeiro tema. Nessa fase, uma vez que tenha sido confirmada a unidade temática do discurso, proceder-se-á à análise das relações do texto discursivo (vv. 19-47) com a parte narrativa do capítulo quinto (vv. 1-18). No primeiro versículo $(5,1)$ há os elementos que deram origem a duas das mencionadas questões, as quais também são objeto da pesquisa realizada no capítulo II (cf. item 2.4). A conclusão da referida pesquisa deverá ser retomada e confrontada com os resultados obtidos por meio da análise textual pragmalinguística. Em seguida, serão apresentadas as outras relações do texto com os contextos próximo e remoto do Evangelho, finalizando numa apreciação da função do referido texto no Evangelho de João.

A partir dessa trajetória, será possível considerar com mais ampla fundamentação as contribuições da análise pragmalinguística ao sentido do discurso de Jo 5,19-47, de modo a melhor evidenciar seu aspecto de novidade para uma moderna hermenêutica. 


\section{2 \\ Principais questões referentes ao capítulo 5 do Evangelho de João}

\section{1. \\ O capítulo 5 e suas peculiaridades}

A menção à problemática da localização do capítulo quinto no contexto do Evangelho de João é um assunto que está sempre presente nos comentários a esse Evangelho. Literariamente Jo 5,1-47 é um texto no qual se distinguem duas seções literárias distintas: uma narrativa (5,1-18) e outra discursiva (5,19-47); ambas apresentam características peculiares. A seção narrativa $(5,1-18)$ chama a atenção pelos detalhes: a ação se passa em Jerusalém (cf. 5,1), onde Jesus cura um paralítico $(5,8)$; o lugar no qual se realiza a cura é um espaço público que, apesar de fazer parte dos arredores do Templo, permite práticas que não estão sob a Lei (como a da piscina com sua água curativa ao ser movimentada); a especificação do nome da piscina e de seus detalhes (5,2s); essa cura não é chamada "sinal"; o tempo é o de uma "festa dos judeus" $(5,1)$; o autor, que em todo o Evangelho está sempre atento aos detalhes, neste texto, não identifica a "festa"; a inesperada relação entre pecado e cura fora do contexto no qual se deu a cura $(5,14)$; a resposta de Jesus sobre seu agir no sábado $(5,17)$ difere de todas dadas nos Evangelhos Sinóticos (cf. Mc 2,23; 3,2 e // Lc 14,1-6).

A segunda seção, o texto discursivo (vv. 19-47), segundo bons comentários ao Evangelho de João, aponta problemas quanto a sua estrutura e unidades literária e temática, além de ser tido, por alguns exegetas ${ }^{23}$, como incompleto. Não raras vezes o capítulo 5 é citado, principalmente, como início da seção dos "conflitos com os judeus" (cap. 5-10), no qual predominam controvérsias com os judeus sobre o sábado ${ }^{24}$ e a defesa de Jesus diante das acusações, ou como apresentando oscilações na maneira de falar de um mesmo tema (a título de

\footnotetext{
${ }^{23}$ Os nomes dos referidos exegetas que defendem essa hipótese, são citados, juntamente com suas obras, no item 2.3 .

${ }^{24}$ Reduzem o conteúdo do discurso às discussões provocadas pelo sábado, e as numerosas tensões que aparecem no corpo do longo discurso são tidas como controvérsias de Jesus com os judeus. Dentre eles: Raymond Brown. Cf. BROWN, R., El Evangelio segun Juan, v. 2, Madrid: Cristiandad, 1979, p. 410. Cf. também KÖNINGS, J., Evangelho segundo João amor e fidelidade, Petrópolis: Vozes/Sinodal, 2005, p. 133.
} 
exemplo: cf. 5,19-25 escatologia realizada e 5,26-30 escatologia futura) ${ }^{25}$. Percebe-se que essa maneira de conceber o texto traz sérios prejuízos à própria cristologia do Evangelho. No entanto, Jo 5,19-47 é um texto que parece ser muito original e realmente instigante!

\section{2.}

\section{A posição de Jo 5 no contexto do Evangelho}

A questão da posição do capítulo de Jo 5 no contexto do Evangelho tem, desde a antiguidade, merecido a atenção dos estudiosos. A problemática, portanto, não é nova. O mais antigo testemunho questionando a posição desse capítulo no Evangelho se encontra em Taciano que, já na segunda metade do século II, inverteu a ordem dos capítulos 5 e 6 em sua obra de harmonização dos Evangelhos, o Diatéssaron ${ }^{26}$. Na época moderna, foi o inglês N. Mann (1733) que retomou o assunto sendo seguido por muitos exegetas na Inglaterra ${ }^{27}$. Em 1928, John Bernard ${ }^{28}$ supôs um deslocamento casual de folhas, ocorrido na redação definitiva por obra de um secretário do evangelista, devido a causas difíceis de serem determinadas. Nos meados do século XX (1950), N. Uricchio ${ }^{29}$ apresentou uma visão panorâmica da história do problema e mencionou 24 autores, católicos e não católicos que, entre 1909 e 1949, defenderam a transposição de capítulos, embora pessoalmente ele tenha se posicionado contra todas as transposições textuais. Lagrange $(1925)^{30}$ também suspeita da troca de capítulos e até admite esta transposição do texto do Evangelho, cuja ordem, diz, é inversa (capítulo 6 antes do capítulo 5). A seguir R. Bultmann" que, ao tratar da "Teoria dos Deslocamentos" ${ }^{, 32}$ no Evangelho de João, transpôs o capítulo 5 para depois do

\footnotetext{
${ }^{25}$ BROWN, R., op. cit., pp. 421 e 433.

${ }^{26}$ Cf. ÉPHREM DE NISIBE, Commentaire de l'Évangile Concordant ou Diatessaron. Tradução de Syriaque et de L'Arménien, Sources Chrétiennes, n. 121, Paris: Les Éditions Du Cerf, 1966, p. 23.

${ }^{27}$ MARTIN, L.; SMITH, D. A.; BERNARD, J.; DODD, C. H.; BARRET, C. K. (estes dois últimos estiveram de acordo só a princípio, depois eles mudaram de opinião); Cf. SCHNACKENBURG, R., El Evangelio según San Juan, v. 2, Salamanca: Herder, 1980, p. 24.

${ }^{28}$ Cf. CASALEGNO, A., Para que contemplem a minha glória, 2009, p. 98.

${ }^{29}$ Cf. URICCHIO, N. La Teoria delle Transposizioni nel Vangelo di S. Giovanni In Biblica, n. 31, 1950, pp. 133-139.

${ }^{30}$ LAGRANGE, M.-J., Évangile selon Saint Jean, 5 a Ed. Paris: Lecoffre, 1966, p. 131-132.

${ }^{31}$ BULTMANN, R., The Gospel of John. A commentary, Oxford: [s.n.], 1971, p. 209.

${ }^{32}$ A teoria dos deslocamentos acidentais se distingue das teorias redacionais que explicam o estado atual do Evangelho, mediante a hipótese de um redator que foi o responsével pela deteriorização do original, ou pela desafortunada combinação de documentos. Cf. BARRET, C. K., El Evangelio según san Juan, Madrid: Cristiandad, 2003, p. 52.
} 
capítulo 6. Na Alemanha, esta teoria de que os capítulos 5 e 6 estariam trocados encontrou inúmeros defensores, entre eles, um dos mais ardorosos foi R. Schnackenburg que, em seu comentário de quatro volumes ao Evangelho de João, impõe a seguinte ordem: o capítulo 4 seguido do capítulo 6; e logo após o capítulo 5, seguido de 7,15-24; 7,1-14. 25-52; 7,53-8,11; 8,12-59; 9 e seguintes. E justifica essa transposição dizendo:

As operações crítico-literárias e as mudanças na disposição do texto atual, só podem acontecer, de acordo com nossos princípios metodológicos, na medida em que o texto apresente força a tais reflexões e existem poderosas razões para a mudança proposta. De há muito se têm sentido as tensões internas, que resultam do ordenamento dos capítulos $5^{\circ}$ e $6^{\circ}$, e que se prolongam até o $7^{\circ}$. Também os intentos de trocar a ordem dos capítulos remontam desde muito tempo atrás ${ }^{33}$.

Schnackenburg ${ }^{34}$ reforça, com muitos argumentos, a "teoria do deslocamento", e é seguido por outros expoentes da exegese joanina ${ }^{35}$. Eis os argumentos que Schnackenburg e outros apresentam a favor da transposição:

- O capítulo 6,1 se articula mal com o capítulo 5. O início do capítulo 6 se encaixa melhor com 4,43-54, uma vez que Jesus já se encontra na Galileia e aí é dito apenas que ele passou para a outra margem do lago da Galileia; e no fim do capítulo 4 (vv. 51-53) se alude uma vez mais ao regresso de Jesus de Jerusalém a Galileia.

- Também o fim do capítulo 6 não se articula bem com o início do capítulo 7 , porém o sentido deste se encaixa melhor com o fim do capítulo 5. Se Jesus já estava na Galileia, no capítulo 6 é estranha a advertência de 7,1: "e depois disto, andava Jesus pela Galileia; pois não queria andar pela Judeia, porque os judeus tramavam matá-lo". Ela é uma referência a 5,18 e se encaixava melhor se não houvesse a interrupção do capítulo 6.

- Não só o capítulo 6 se situa melhor após o capítulo 4, mas também o capítulo 5 flui sem dificuldades, após o capítulo 6. Uma vez que o leitor conhece a deserção dos discípulos (v. 66) e a confissão de Pedro (vv. 68-69), o autor faz saber que

\footnotetext{
${ }^{33}$ Cf. SCHNACKENBURG, R., El Evangelio según San Juan, p. 17.

${ }^{34} \mathrm{Cf}$. Ibid., p. 24 passim.

${ }^{35}$ Cf. GUILDING, A., The Fourth Gospel and Jewish Worship, Oxford: At The Clarendon Press, 1960, p. 45 et seq; LINDARS, B., The Gospel of John, NCBC, London: Marshall, Morgan \& Scott, 1981, p. 50; BLANK, J., O Evangelho segundo João, v. 4/1b, Petrópolis: Vozes, 1991, p. 62; SCHELKLE, K. H., Teologia do Novo Testamento, v. 2, São Paulo: Loyola, 1977, p. 80; SLOYAN, G., Giovanni, Torino: Claudiana, 2008, p. 105.
} 
Jesus vai a Jerusalém para uma festa. Tal crise da Galileia põe ponto final na atividade de Jesus naquela região.

- Além disso, no capítulo 7 após a mencionada alusão ao ódio mortal dos judeus, surpreende a referência a "uma obra" em 7,21, com a qual se indica de maneira inequívoca, de acordo como os versículos imediatos, a cura do paralítico da piscina de Betzata. O problema que é recordado aqui se soluciona supondo que a passagem 7,15-24 estaria originalmente no final do capítulo 5. Seném Vidal e J. Ashton argumentam ${ }^{36}$ que, além do deslocamento do capítulo, o texto de 7,15-24, que originalmente concluía o capítulo 5, após o v. 47, fora deslocado para o capítulo 7. Indícios de crítica redacional lhes fornecem argumentos: nos vv. 15-24 do capítulo 7 continua a discussão sobre a cura no sábado, a ameaça de morte feita a Jesus, a acusação da violação do sábado, o tema da glória, do julgamento, do enviado, de Moisés; além da evidente alusão em 7,23 ao milagre do capítulo 5; enfim, o vocabulário está (cf. v. 21-23) em clara referência ao relato e à discussão do capítulo 5, e não se enquadra com a situação e a temática de 7,1-14. 25-52. Por uma parte, 7,15-24 corta a sequência entre 7,14 e 7,25; e por outra parte, 7,1-14 interrompe a sequência entre 5,47 e 7,15. A indicação de uma festa em 5,1 se compreenderia então melhor.

- O evangelista até agora só havia falado de uma festa pascal $(2,13.23 ; 4,45)$. Uma segunda páscoa é mencionada em 6,4. Parece que nesta páscoa ele não subiu a Jerusalém, pois se encontrava nas margens do lago da Galileia $(6,4)$. É pouco provável que entre estas duas festas Jesus houvesse ido a Jerusalém participar de outra festa menos importante. Entender esta festa inominada como uma segunda festa pascal é difícil por vários motivos. Mais compreensível é a hipótese de que Jesus, após retirar-se da Judeia para a Galileia, evitou ir a Jerusalém, atuando somente pela Galileia. Com a inversão dos capítulos persiste certamente o problema de qual é a festa.

- O resultado é uma coincidência surpreendente com a exposição dos Sinóticos: os três primeiros Evangelhos supõem uma atividade maior de Jesus na Galileia; segundo o quadro de Marcos, depois da multiplicação dos pães começa um período no qual Jesus se afasta mais do povo da Galileia ("peregrinações

${ }^{36}$ Cf. VIDAL, S., Los Escritos Originales de la Comunidad del Discípulo Amigo de Jesus, Salamanca: Sigueme, 1997, pp. 34-36; Cf. ASHTON, J., Compreendere il Quarto Vangelo, Città del Vaticano: Ed. Vaticana, 2000, p. 196. 
errantes"). Sem atribuir a esse feito (como tão pouco ao relato de viagem lucano) uma maior importância, parece que a comida milagrosa dos pães marca o ponto mais alto da atividade galilaica de Jesus. Todo esse período, o supõe o Quarto Evangelho (cf. 6,2), porém não o descreve; o quarto evangelista conduz de imediato ao auge (e ao movimento decisivo) da atuação de Jesus na Galileia. O impulso até Jerusalém só pode ser seguido com o calendário das festas dos capítulos 5-7-10-11s. Porém este argumento tem mais um caráter de apoio.

- Supõe-se que o autor, de idade avançada, teria morrido antes da conclusão de sua obra ${ }^{37}$.

Mais recentemente, a teoria do deslocamento teve também novos defensores $^{38}$, dentre os quais, J. Zumstein ${ }^{39}$. Segundo esse exegeta, a indicação topográfica de 6,1 (Jesus passou para a outra margem do mar da Galileia) cabe mal no contexto, porque o conjunto do capítulo 5 se desenrola em Jerusalém. Pelo contrário, invertendo-se a ordem dos capítulos 5 e 6, recupera-se a coerência do quadro topográfico. Além disso, segundo ele, o discurso proferido pelo Cristo joanino, por ocasião da festa das Tendas, em 7,15-24, evoca a intenção dos judeus de suprimir Jesus, acusado de transgredir o sábado. Por isso, essa passagem parece fazer eco à cena de 5,1-18 e constituir a continuação lógica de 5,19-47. Combinando-se essas duas observações, chega-se à reconstrução da ordem inicial desses capítulos, que parece ter sido subvertida, da seguinte maneira: $4 ; 6 ; 5 ; 7,15$ 24. $1-14.25 \mathrm{ss}$.

Apesar de ser defendida ainda hoje, porém, já na segunda metade do século passado exegetas como, N. Uricchio ${ }^{40}$ (1950), C. H. Dodd ${ }^{41}$ (1950) e C. K. Barret $^{42}$ (1955) colocaram em dúvida essa teoria, preferindo renunciar a qualquer

\footnotetext{
${ }^{37}$ Assinala Kümmel: "A tese de que o autor teria deixado incompleta sua obra, antes de falecer, do ponto de vista metodológico não há objeção contra essa tese, embora não possamos entender por que o autor não teria eliminado as dificuldades mais óbvias $(6,1$ !). Se não existisse uma tradição da Igreja primitiva, segundo a qual o apóstolo João teria escrito este evangelho numa idade bem avançada, é muito duvidoso que alguém levantasse esta hipótese baseado no exame do próprio evangelho". Cf. KÜMMEL, G., Introdução ao Novo Testamento, São Paulo: Paulinas, 2009, p. 275.

${ }^{38}$ Cf. GRASSO, S., Il Vangelo di Giovanni, Commento exegético e teológico, Roma: Città Nuova, 2008, p. 234, nota 5; SLOYAN, G., Giovanni, Torino: Claudiana, 2008, p. 105; Cf. ASHTON, J., Comprendere il Quarto Vangelo, p. 196; Cf. VIDAL, S., Los Escritos Originales de la Comunidad del Discípulo Amigo de Jesús, p. 34 e outros.

39 Cf. ZUMSTEIN, J., O Evangelho segundo João, In MARGUERAT, D. (Org.)., Novo Testamento - História, Escritura e Teologia, São Paulo: Loyola, 2009, p. 443.

${ }^{40}$ URICCHIO, N., La Teoria delle Transposizioni nel Vangelo di S. Giovanni In Biblica, n. 31, 1950, pp. 129-163.

${ }^{41}$ Cf. DODD, C. H., Interpretación del Cuarto Evangelio, Madrid: Cristiandad, 2004, p. 421.

${ }^{42}$ Cf. BARRET, C. K., El Evangelio según San Juan, p. 50.
} 
troca, visto que ela não oferecia nenhuma solução totalmente satisfatória ao problema. A seguir, estudiosos da teoria redacional do Quarto Evangelho, cujos expoentes foram E. Boismard ${ }^{43}$ no início, e R. Brown ${ }^{44}$ em seguida, não apoiaram a teoria do deslocamento, por considerarem as dificuldades apresentadas uma questão de crítica textual e redacional. Assim também G. Kümmel atribui a troca ao progresso redacional do Evangelho. E argumenta:

Se fosse simplesmente um deslocamento de folhas inteiras, então o conteúdo das folhas deslocadas deveria ter a mesma extensão. Mas as tentativas para provar isso esbarram contra o fato de que em nenhum caso os intervalos entre as alegadas folhas deslocadas têm a mesma extensão ou um múltiplo equivalente ${ }^{45}$.

Atualmente, com eles, muitos outros estudiosos comungam desta opinião ${ }^{46}$. Uma terceira hipótese, apresentada pelo exegeta B. Lindars ${ }^{47}$, atribui a inserção do capítulo 6 entre os capítulos 5 e 7. Para ele o capítulo 6 constitui uma inserção posterior e foi posto aqui, porque fornece uma boa explanação sobre a afirmação de Jesus na qual ele diz que Moisés escreveu sobre ele: "sobre mim ele escreveu" $(5,46)$. Reforçando essa tese, J. Ashton diz: “A solução de Lindars, elegante e conveniente, oferece uma saída ao impasse, pois Jesus, no capítulo 6, ainda se encontrava na Galileia, só passando para a outra margem do lago"48.

As diversas hipóteses suscitadas sobre a questão de que o texto de João 5,147 não nos teria sido transmitido na sequência pretendida pelo autor, podem ser assim sintetizadas:

a) A hipótese literária mais explícita se baseia nas indicações topográficas que iniciam os capítulos 4; 5; 6; em 4,6 Jesus havia deixado a Judeia, dirigindo-se para a Galileia; e já em 5,1 ele está novamente em Jerusalém. Logo a seguir em 6,1 está de volta à Galileia.

\footnotetext{
${ }^{43}$ Cf. BOISMARD, M.-É.; LAMOUILLE, A., L'Évangile de Jean, v. 3, Paris: Éditions du Cerf, 1977, p. 152 et seq.

${ }^{44}$ BROWN, R., El Evangelio según San Juan, p. 414.

${ }^{45}$ Cf. KÜMMEL, G., Introdução ao Novo Testamento, p. 260 et seq.

${ }^{46}$ Cf. BARRET, C. K., op. cit., p. 54; SIMOENS, Y., Selon Jean une Traduction, une Interpretation, v. 1, Bruxelles: Institut d'Études Théologiques, 1997, p. 237; CARSON, D., $O$ Comentário de João, São Paulo: Shedd Publicações, 2007, p. 268; CABA, J., Cristo, Pan de Vida, Teología eucarística del IV Evangelio, Madrid: BAC, 1993, p. 33; BEASLEY-MURRAY, G., John, WBC, v. 36, 1999, p. 43; MATEOS, J.; BARRETO, J., O Evangelho de São João, São Paulo: Paulinas, 1989, p. 285.

${ }^{47}$ Cf. LINDARS, B., The Gospel of John, NCBC, London: Marshall, Morgan \& Scott, 1981, p. 49; ASHTON, J., Comprendere il Quarto Vangelo, p. 196.

${ }^{48}$ Cf. ASHTON, J., op. cit., p. 196.
} 
b) Outras duas hipóteses se fundamentam em indicações cronológicas $^{49}$ : uma baseada na omissão $(5,1)$ da indicação do nome da "festa dos judeus". (Essa ausência se justificaria se ao capítulo 5 seguissem imediatamente os capítulos 7-8$9 \mathrm{ss})^{50}$. E a outra na sucessão das festas do calendário do Templo. Este argumento deriva da hipótese de que o evangelista contextualizou as ações de Jesus em Jerusalém a partir do calendário das festas judaicas (cf. 2,13. 23; 7,2. 14; 10,22; 12,1. 12).

c) Há ainda outra hipótese que supõe que o capítulo 6 não fazia parte do evangelho original, mas teria sido acrescentado posteriormente, de modo que a sequência ficou distorcida. A inserção do capítulo 6 entre os capítulos 5 e 7 - e não a transposição do capítulo 5 - teria originado o problema. Assim também pensam exegetas mais modernos.

d) Por fim as que são fundamentadas em critérios literários ${ }^{51}$, nas tensões temáticas provocadas pelo próprio texto ${ }^{52}$, e a da suposição de que o autor, de idade avançada, teria morrido antes da conclusão de sua obra ${ }^{53}$.

Segundo as referidas teorias, a atual posição deste capítulo 5 constitui uma dificuldade bem característica, não só por causa das circunstâncias topográficas e cronológicas, como também pela inconclusão ${ }^{54}$ do texto discursivo (vv. 19-47) e sua relação com o capítulo 7,15-24. No entanto, nenhuma dessas teorias é suficiente para explicar o estado atual do Evangelho ${ }^{55}$. Acrescente-se o fato de que

\footnotetext{
49 Guilding acrescenta: "Se por um lado a teoria do deslocamento fala a favor de uma ordem geográfica, por outro é exatamente um indício de uma estrutura a partir de uma missão de Jesus em Samaria e Galileia (cap. 4 e 6), e de outra alicerçada no calendário das festas (cf. ciclos das festas: caps. 5-7-10-11s) e nos conflitos em Jerusalém (5-10)”. Cf. GUILDING, A., The Fourth Gospel and Jewish Worship, p. 45 et seq.

${ }^{50}$ Segundo Vidal, se o lugar do capítulo 5 fosse atrás do capítulo 6, os indícios de que a festa seria a da Páscoa seriam claros, pois em 6,4 se diz que estava próxima a festa da Páscoa. Cf. VIDAL, S., Los escritos Originales de la Comunidad del Discípulo Amigo de Jesús, p. 34 et seq.

${ }^{51}$ Cf. Ibid., pp. 34-36; Cf. ASHTON, J., op. cit., 2000, p. 196.

52 Por exemplo, segundo Brown, as duas escatologias (5,24; 5,25-29). Cf. BROWN, R., El Evangelio según San Juan, p. 414.

${ }^{53}$ Assinala Kümmel: "A tese de que o autor teria deixado incompleta sua obra, antes de falecer, do ponto de vista metodológico não há objeção contra essa tese, embora não possamos entender por que o autor não teria eliminado as dificuldades mais óbvias $(6,1$ !). Se não existisse uma tradição da Igreja primitiva, segundo a qual o apóstolo João teria escrito este evangelho numa idade bem avançada, é muito duvidoso que alguém levantasse esta hipótese baseado no exame do próprio evangelho". Cf. KÜMMEL, G., Introdução ao Novo Testamento, 2009, p. 275.

${ }^{54}$ Sobre a questão da inconclusão do discurso tratar-se-á dela quando da análise da delimitação do texto no capítulo 4.1.3.

${ }^{55}$ Simoens observa que, mesmo sem negar o caráter abrupto da passagem a Jerusalém, nem a dificuldade que consiste em voltar, em seguida à Galileia, é preciso reconhecer que a "teoria dos deslocamentos" põe finalmente mais problemas que os resolve. (...) "Trata-se de procurar
} 
não há nenhum manuscrito que apresente outra ordem ao Evangelho ${ }^{56}$ e também que ninguém ainda conseguiu demonstrar de maneira convincente que o Evangelho foi baralhado ${ }^{57} \mathrm{e}$, por isso, a hipótese de uma transposição secundária não pode resolver o problema literário de João ${ }^{58}$. Quem publicou o Evangelho sabia o que fazia ${ }^{59}$. A exegese tem que explicar o texto completo. Não seria o caso de perguntar se a intenção do autor não oferece outra possibilidade de explicação?

\section{3.}

\section{A identificação da "festa" de Jo 5,1}

Na introdução ao capítulo 5 (cf. 5,1) se lê que Jesus subiu a Jerusalém por ocasião de uma "festa dos judeus" (èrth. twh Voudai wn) ambientando, portanto, a cena que vai ser narrada, no contexto de uma festa judaica. O termo grego eòrth, não vem precedido pelo artigo definido 60 “ o'”, o que dificulta ainda mais sua especificação; pois se viesse antecedido pelo artigo “ 0 ”, poderia se identificar a festa com "a festa dos judeus" ${ }^{61}$, que designava em geral a festa da Páscoa ou a festa das Tendas. Essa é a única festa no Evangelho de João que não é nomeada com mais precisão e também a única vez em que a expressão "festa dos judeus" não vem antecedida pelo artigo. $\mathrm{Na}$ exegese do capítulo 5 ela tem sido identificada com "a festa da Páscoa", de "Pentecostes", "dos Tabernáculos", "Purim", "Rosh Hashanah", e, além dessas, com o "Sábado". Esclarecer de que "festa" se trata tornou-se um desafio para muitos estudiosos do Evangelho de

compreender o relato tal qual se apresenta, em que pesem as dificuldades". Cf. SIMOENS, Y. Selon Jean, v. 1, p. 237.

${ }_{56}$ Os Papyros: $\mathrm{P}^{66}, \mathrm{P}^{75}$, e as versões siríacas trazem o Evangelho na ordem atual. Cf. LUZARRAGA, J., El Evangelio de Juan en las versiones siríacas., Subsídia Bíblica, n. 33, Roma: Pontificio Istituto Biblico, 2008.

${ }^{57}$ Keener observa que enquanto a transposição é concebível para páginas em códice, é difícil conceber um acidente nas primeiras versões em rolos, pois nenhum manuscrito atesta essa transposição. Cf. KEENER, C., The Gospel of John. A Commentary, v. 1, Massachussetts: Hendrickson Publishers, 2005, p. 634.

${ }_{58}^{58}$ KÜMMEL, G., op. cit., p. 265 et seq.

${ }^{59}$ Cf. BARRET, C. K., El Evangelio según San Juan, p. 55.

${ }^{60}$ A leitura sem artigo é melhor atestada: cf. $\mathrm{P}^{66}, \mathrm{P}^{75}, \mathrm{~A}, \mathrm{~B}, \mathrm{D}, \mathrm{N}, \mathrm{W} \mathrm{Q}$ e outros. Alguns manuscritos na tentativa de identificar a festa trazem o artigo diante do substantivo festa "a festa": a, C, I, K, D, P, além de Taciano e Orígenes.

${ }^{61}$ A expressão "festa dos judeus" reaparece no Evangelho em 6,4 e 7,2, sempre identificando a festa. Indica uma festa judaica oficial e tem a função de contrapor o tempo de Jesus com o do calendário judaico do Templo. Segundo Grasso trata-se de uma técnica do evangelista que coloca muitas passagens do evangelho no contexto das festas hebraicas oficiais (cf. 2,13. 23; 6,4; 7,2; 10,22; 12,1; 13,1). Cf. GRASSO, S., Il Vangelo di Giovanni, p. 234, nota 5. 
João. Há várias hipóteses propondo determinar a natureza da "festa dos judeus" de Jo 5,1:

A festa seria a da Páscoa

- Justificar-se-ia, se o capítulo 5 viesse atrás do capítulo 6 , onde há indícios claros de uma próxima festa da Páscoa ${ }^{62}(6,4)$, pois, assim como a Páscoa de 2,13, a festa qualifica-se de "festa dos judeus" 63 .

- Pela omissão do nome da festa, pois conforme o evangelista "a festa" (considerando-se a palavra festa antecedida pelo artigo) significava a festa da Páscoa ${ }^{64}$.

- O fato de a menção da "festa dos judeus" vir acompanhada pelo verbo "subir" (anebe் $h$ ), que em João designa a subida de Jesus a Jerusalém, sinaliza para uma das três festas de peregrinação: Páscoa, Pentecostes e Tendas $(2,13 ; 7,10){ }^{65}$.

- Também a temática do discurso (vv. 19-47) reforçaria esta opinião: A proximidade de Deus com seu povo por meio de Moisés, o profeta, que falou com Deus e ouviu dele a ordem para escrever as Escrituras, evocava os acontecimentos do Sinai, tema da liturgia da festa da Páscoa judaica ${ }^{66}$.

- Pressupõe para os cristãos a "Páscoa" da morte de Jesus ${ }^{67}$, que naquele ano caiu em dia de sábado: "Como era a Preparação, os judeus, para que os corpos não ficassem na cruz durante o sábado, porque esse sábado era grande dia!...” (cf. Jo 19,31). O autor cristão tinha em mente o pensamento da cruz e da ressurreição de Jesus, tema do discurso, no qual estaria desenvolvendo a sua cristologia e escatologia do presente ${ }^{68}$.

\footnotetext{
${ }^{62}$ Cf. VIDAL, S., Los Escritos Originales de la Comunidad del Discípulo Amigo de Jesús, p. 34 et seq.

${ }^{63}$ Conforme Brown, 'Testemunhas da Patrística' como Taciano e Ireneu de Lyon (Adv. Haer 2,22. 3-4) concluem que a festa é a da Páscoa. Cf. BROWN, R., El Evangelio según Juan, p. 413. Lagrange também os acompanha. Cf. LAGRANGE, M.-J., Évangile selon Saint Jean, pp. 131132.

${ }^{64}$ A Páscoa é citada no Evangelho em: 2,13. 23; 6,4; 11,55. 55; 12,1; 13,1; 18,28. 39; 19,14. Cf. 11,56: "Virá ele à festa?"; 12,1: "a grande multidão que viera para a festa"; 12,20: "durante $a$ festa" referindo-se à Páscoa (cf. v. 55).

${ }^{65}$ Cf. MANNS, F., L'Évangile de Jean et la Sagesse, Studium Biblicum Franciscanum, Analecta, n. 62, 2003, p. 131. Esta informação exclui as festas de Purim e a de Rosh Hashanah.

${ }^{66}$ Cf. INFANTI, R., Le feste di Israele nel Vangelo Secondo Giovanni, Milano: Edizioni San Paolo, 2010, p. 79.

${ }^{67}$ O Evangelho faz cinco menções da Páscoa em relação com Cristo: 12,1; 13,1; 18,28. 39; $19,14$.

${ }^{68}$ BLANK, J., O Evangelho segundo João, p. 11.
} 
A festa seria a de "Pentecostes" ou "festa das semanas" Inúmeros exegetas ${ }^{69}$ respaldam essa hipótese, baseando-se nos seguintes pontos:

- A sucessão cronológica das festas no Evangelho: a Páscoa de 2,13, Pentecostes no 5,1, e a Páscoa do 6,4; a festa dos Tabernáculos ou das Tendas no 7,2 e da Dedicação no 10,22 e a última Páscoa no 12,1. O capítulo 5 se insere no arco das quatro festas que determinam o programa cronológico e teológico iniciado em 5,1 até $10,42(5,1 ; 6,4 ; 7,2 ; 10,22)^{70}$.

- A festa de 5,1 está relacionada com a situação de Jo 4,35-38 que menciona o provérbio: "Ainda quatro meses e chegará a colheita". A importância do contexto seria evidente, pois fala da aproximação da "Festa das colheitas"

- Pentecostes era a celebração da entrega da Lei a Moisés no Monte Sinai, na qual se fazia a memória do dom da Lei ${ }^{72}$. Faz sintonia com o discurso de Jo 5 (vv. 21. 26) que fala do "dom" e de Moisés, mencionado nos vv. 46-47. A temática da festa era o Dom da Torá com a renovação da Aliança, tema do discurso ${ }^{73}(5,19$ 47). "Se a festa é Pentecostes, o tema do julgamento se deve à relação existente entre esta festa e a entrega das tábuas da Lei do Sinai" ${ }^{74}$.

- O capítulo 5 não estaria deslocado, segundo Boismard e Lamouille. Assim o evangelho comportava uma sequência perfeita das festas oficiais de peregrinação: Pentecostes 5,1, que se situava entre a festa da Páscoa de 2,13, e a festa das Tendas de $7,2^{75}$.

\footnotetext{
${ }^{69}$ Testemunhas da Patrística: JOÃO CRISÓSTOMO, Le Omelie su S. Giovanni Evangeliste. parte II, 1947, p. 290; CIRILO DE ALEXANDRIA (PG 73, 337-338); INFANTI, R., op. cit., p. 79; SCHNACKENBURG, R., El Evangelio según San Juan, p. 27 e 130; BOISMARD, M.-E. ; LAMOUILLE, A., L'Évangile de Jean, p. 160; SIMOENS, Y., Selon Jean, v.1, p. 237; RIGATO, M.-L., Giovanni: L'Enigma, Il Presbitero, Il Culto, Il Tempio, la Cristologia. Bolonha: EDB, 2007, p. 122; GHIBERT, G., Opera Giovannea, Torino: Elledici, 2003, pp. 35 e 41; WENGST, K., Il vangelo di Giovanni, Brescia: Queriniana, 2005, p. 196; BAUCKHAM, R.; MOSSER, C., The Gospel of John and Christian Theology, Cambridge: Eerdmans Publishing, 2008, p. 296.

${ }^{70}$ Cf. RIGATO, M.-L., Giovanni, p. 210.

${ }^{71}$ Cf. MANNS, F., L'Évangile de Jean et la Sagesse, p. 130.

${ }^{72}$ Esta festa se relaciona com o dom da Lei no Sinai. Cf. BOISMARD, M.-É. ; LAMOUILLE, A., L'Évangile de Jean, v. 3, Paris: Éditions du Cerf, p. 160.

${ }^{73}$ Conforme Rigato, no Novo Testamento o relato de Pentecostes do livro dos Atos (At 2,1 passim) faz referência à festa judaica de peregrinação, cinquenta dias depois da Páscoa. Cf. RIGATO, M.-L., op. cit., p. 210.

${ }^{74}$ Cf. BROWN, R., op. cit., p. 414.

${ }^{75}$ Cf. BOISMARD, M.-É.; LAMOUILLE, A., op. cit., p. 160 et seq. Neste seu argumento ele ignora a festa da Páscoa de 6,4.
} 
- Para Schnackenburg ${ }^{76}$, após a Páscoa de 6,4, com o deslocamento do capítulo 5 para depois do capítulo 6, a festa inominada seria Pentecostes, cuja indicação cronológica coincide com o restante do evangelho e começa aqui em 5,1, um calendário de festas, que continua com a festividade dos Tabernáculos (cap. 7), a dedicação do Templo (cap. 10) e a última Páscoa (cap. 11-12). No entanto, ele acrescenta que o evangelista não se interessa pelo curso cronológico, e sim, por cada acontecimento importante para Jesus e sua revelação. Segundo ele, aqui a indicação só serve como marco para uma história que o evangelista encontrou em sua fonte.

A festa seria a dos Tabernáculos ou Tendas

- Os defensores ${ }^{77}$ dessa opinião recorrem a argumentos de crítica textual, apoiando-se nos manuscritos que apresentam o artigo diante da palavra "festa" e também na "Tradição" dos Pais da Igreja ${ }^{78}$. Geralmente a festa dos Tabernáculos ou das Tendas vem indicada somente como "a festa" (cf. 1 Rs 8,2; Ez 45,25; 2 Cr 7,8; Ne 8,14), ou uma "festa do Senhor" (cf. Lv 23,39; Nm 29,12), a última das três festas de peregrinação, chamada em Jz 21,19 de "a festa anual do Senhor" 79 .

- A festa de 5,1 está em paralelo com a festa das Tendas. A alusão feita ao dia de sábado em 7,21 sugere que o autor quer indicar um paralelismo com o capítulo 7 (5,19-47 // 7,1-8,58), justificando-se a omissão do nome da festa, que, portanto, seria a dos Tabernáculos ou das Tendas. E isso favorecia o calendário das festas judaicas $^{80}$.

- A festa era associada ao Êxodo, especificamente à caminhada do povo no deserto (Ex 34,22), à proclamação pública da Torá (Dt 31,10-13), à reminiscência da proteção divina (cf. Is 32,18). Está em consonância com a temática do discurso que relaciona Moisés com a Torá ${ }^{81}$. É a mais frequentada e a mais alegre das festas.

\footnotetext{
${ }^{76}$ Cf. SCHNACKENBURG, R., op. cit., p. 130.

${ }^{77}$ Cf. MANNS, F., op. cit., p. 130.

78 Testemunhas da Patrística: Orígenes, Taciano e Cipriano defendiam tratar-se da festa dos Tabernáculos e são de acordo com os manuscritos que trazem a presença do artigo diante do nome festa em a, C, L, K, D, P, Y, 33; também o minúsculo 131 (séc. IX) fala da festa das Tendas. Cf. MANNS, F., L'Évangile de Jean et la Sagesse, 2003, p. 130.

${ }^{79}$ Ibid., p. 122 passim.

${ }^{80}$ Cf. VAN DEN BUSSCHE, H., Guérison d'un paralytique a Jérusalém. Le jour du sabbat. Jean 5,1-18, In Bible et Vie Chrétienne, v. 61, 1966, pp. 18-28.

${ }^{81}$ Cf. MANNS, F., op. cit., 2003, p. 131.
} 
- O Lv 23,43 acrescenta a motivação de caráter histórico salvífico. A festa inteira assume um simbolismo escatológico com significado messiânico, em relação à espera messiânica (Zacarias 14) ${ }^{82}$. A habitação em Tendas por sete dias relembrava a presença do Senhor no meio deles, tema do discurso de 5,19-47. É o primeiro dia da Festa em que o Senhor pousará seus pés sobre o Monte das Oliveiras. A "peregrinação de Deus" é o tema principal que engloba todos os outros $^{83}$.

- No capítulo 7 a temática da "festa dos Tabernáculos" está relacionada especialmente com o discurso de 5,19-47 que, para alguns, se prolonga no texto de 7,15-24, continuando a discussão sobre a cura no sábado, a ameaça de morte feita a Jesus, a acusação da violação da Lei, o tema da glória, do julgamento, do enviado, de Moisés; enfim, o vocabulário estaria (cf. vv. 21-23) em clara referência ao relato e ao discurso de 5,1-47.

$>$ A festa seria a do Purim

- A hipótese de que a festa seria a festa do Purim deve-se à comparação entre o texto de Jo 4,35 e 6,4. A temática do discurso estaria ligada ao julgamento do povo e à benevolência de Deus. Nessa festa, que antecedia à Páscoa, se celebrava a salvação do povo judeu ${ }^{84}$.

\section{A festa seria a do Rosh Hashanah}

- A hipótese de que a festa seria a de Rosh Hashanah, a festa do Ano Novo, duas semanas antes da festa de peregrinação dos Tabernáculos ou Tendas, encontra um grande defensor em A. Guilding, cujos argumentos supõem a inversão da ordem dos capítulos que seria 4, 6, 5, 7. O tema do discurso está em consonância com o seguimento do lecionário das Sinagogas, o qual estava cheio de temas de julgamento naquela época do ano. Menciona ainda a evidência da Mishnah e dos escritos rabínicos sobre a ressurreição futura e o julgamento (cf. 5,22. 27. 29), temas centrais da festa de Rosh Hashanah, paralelos a João $5,19 \mathrm{ss}^{85}$. Também o

\footnotetext{
${ }^{82}$ Cf. INFANTI, R., Le feste di Israele nel Vangelo secondo Giovanni, Milano: San Paolo, 2010, p. 117.

${ }^{83}$ Cf. Ibid., p. 120.

${ }^{84}$ Segundo Keener há poucos argumentos para sustentar esta hipótese e entre os exegetas somente Bowman, Watkins. Cf. KEENER, C., The Gospel of John, p. 635.

${ }^{85}$ Cf. GUILDING, A., The Fourth Gospel and Jewish Worship, p. 70 et seq.
} 
contexto poderia favorecer a festa de Ano Novo, festa da criação do mundo (cf. $5,17)^{86}$.

Não é nenhuma das cinco festas

- A omissão de João em não especificar a festa seria deliberada ${ }^{87}$. A festa de 5,1 não se relaciona com nenhuma festa e João introduz aqui $(5,1)$ uma festa simplesmente para dar razão da presença de Jesus em Jerusalém. Se outras festas são mencionadas é porque o contexto em cada caso acha Jesus fazendo ou dizendo algo relacionado a ela. Por implicação, se a festa em João 5 não é identificada, seria provavelmente porque o material em João 5 não pretenderia ser tematicamente relacionado a ela ${ }^{88}$.

A festa seria o sábado ${ }^{89}$

A hipótese de que a festa seria o "Sábado" baseia-se em:

- O sábado é mencionado explicitamente no próprio capítulo ${ }^{90}$ (5,9c. $10 \mathrm{~b}$. 16b. 18c). Segundo Brown "o sábado seria o centro da narrativa (5,1-47); sem dúvida a única interpretação que João dá é que "aquele dia era um sábado" $(5,9 \mathrm{c})$, e que outras indicações possuem valor secundário"91.

- Segundo Mlakuzhyil, exceto para o sábado, as festas são explicitamente mencionadas. No livro do Levítico $(23,3)$ o ritual das festas começa com o sábado, que é chamado de solenidade ${ }^{92}$.

- Para Keener a questão real do calendário no capítulo não é uma festa anual, mas o sábado no qual Jesus afirma sua divina autoridade, como enviado de Deus tema do discurso - para adaptar a regra sabática ${ }^{93}$.

\footnotetext{
${ }^{86}$ ROLLAND, P., Présentation du Nouveau Testament selon l'ordre chronologique et la structure littéraire des écrits apostoliques, [S.n.]: Éditions Ode Paris, 1995, p. 559, nota 2.

${ }^{87}$ Cf. CARSON, D., O comentário de João, p. 241; FABRIS, R.; MAGGIONE, B., Os Evangelhos, v. 2, São Paulo: Loyola, 2006, p. 330 et seq.

${ }^{88}$ Grasso não defende nenhuma festa. Porém acrescenta que da notícia sobre a chegada à Cidade Santa se pode deduzir que o evangelista refere-se a uma das três festas de peregrinação às quais o hebreu era convidado a subir a Jerusalém: Páscoa, Tendas e Pentecostes. Cf. GRASSO, S., Il Vangelo di Giovanni, p. 234.

${ }^{89}$ No Quarto Evangelho o sábado aparece em 5,9. 10. 16. 18; 7,22. 23; 9,14. 16; $19,31$.

${ }^{90}$ Cf. MOLLONEY, F., Il Vangelo di Giovanni, Sacra Pagina, Torino: Elledici, 2007, p. 146.

${ }^{91}$ Cf. BROWN, R., El Evangelio según Juan, p. 414.

${ }^{2}$ Cf. MLAKUZHYIL, G., The Christocentric Literary Structure of the Fourth Gospel, Roma: Pontificio Istituto Biblico, AnBib, n.117, 1987, p. 103.

${ }^{93}$ Cf. KEENER, C., The Gospel of John, p. 635.
} 
Concluindo:

Para tentar especificar a festa de 5,1, os argumentos, muitos e variados, se fundamentaram: ora na topografia do Evangelho, ora na cronologia do calendário litúrgico judaico, ora na crítica textual e redacional, ora na ligação com a temática do discurso; porém não há nenhuma hipótese, com argumentos de peso, que realmente identifique a festa. Entretanto, se o sábado é considerado uma festa, essa teoria teria que ser respaldada pelo contexto de 5,17: "Meu Pai trabalha até agora, e eu também trabalho"; pois esse "sábado" $(5,9)$ deve ter um alcance semântico relativo à criação, haja vista que o sábado da cura do cego (cf. 9,14. 16) não está referido a nenhum acontecimento festivo. A verdade é que essa "festa" de João em 5,1 continua anônima.

\section{4 . \\ Questões referentes ao discurso de Jo 5,19-47}

O texto de Jo 5,19-47 é comumente conhecido como "Discurso de revelação". As principais dificuldades referentes a este discurso aparecem quando se confronta, nos comentários exegéticos do capítulo 5 do Evangelho de João, a forma de considerar a estrutura literária e temática do texto em questão e, consequentemente, sua interpretação.

\subsection{1.}

\section{A estrutura literária do discurso 5,19-47}

O critério para definir a estrutura do discurso de 5,19-47 apresenta-se, nesses comentários, de modo muito diversificado, dependendo do princípio que se $\operatorname{adote}^{94}$. Podem-se discernir quatro diferentes grupos de estrutura literária:

1. A que divide o discurso em duas partes: 5,19-30; 31-47;

2. A que o divide em três partes: 5,19-30; 31-40; 41-47;

3. A que considera o discurso inconcluso tendo sua conclusão lógica o texto de 7,15-24. A estrutura seria: 5,19-30; 31-47; 7,15-24.

4. A que considera o discurso uma unidade literária: 5,1-47.

\footnotetext{
${ }^{94}$ Léon-Dufour apresenta em um quadro as subdivisões do capítulo 5, propostas desde Wescott até Haenchen. As divergências recaem principalmente sobre a divisão entre os vv. 9 e 10, 15 e 16, 3839, 40 e 41. Cf. LÉON-DUFOUR, X., Leitura do Evangelho segundo João, v. 2, São Paulo: Loyola, 1998, p. 17.
} 
1. A divisão mais comum é a que considera o discurso estruturado em duas partes e iniciando-se no v. 19. Para essa divisão, seus defensores se fundamentam em critérios literários e temáticos ${ }^{95}$. Um argumento de crítica literária é o que considera que os vv. 19-30, que constituem a primeira parte do discurso, estariam delimitados por uma inclusão. Para Schnackenburg ${ }^{96}$ o v. 30a coincide literalmente com a frase inicial do discurso no v. 19, com a diferença de que no v. 30 Jesus fala em primeira pessoa. Léon-Dufour vê um quiasmo elaborado no interior da inclusão, com o v. 24 no centro do quiasmo ${ }^{97}$. Já Brown vê um paralelismo entre os vv. 19-25 e vv. 26-30, os quais apresentam duas escatologias - presente e futura, com a intenção de criar uma inclusão que unifique toda a passagem $^{98}$. O v. 30 constituiria o arremate do grande texto escatológico ${ }^{99}$. Porém os argumentos mais numerosos são temáticos ${ }^{100}$. Alguns autores divergem quanto ao início do discurso que se iniciaria a partir do v. 16 (16-30; 31-40) ou a partir do v. 17 (17-30; 31-40) ${ }^{101}$. Estes entendem que os vv. 16-18 seriam a introdução do discurso.

2. O discurso divide-se em três partes ${ }^{102}: 5,19-30 ; 31-40 ; 41-47$. Em geral o critério é temático.

\footnotetext{
${ }^{95}$ Há correspondências verbais e temáticas muito estreitas entre o v. 19 e o v. 30 , v. 20 e vv. 28 , 29, v. 21 e 26, v. 22 e 27, e v. 24 e 25. Cf. CARSON, D. A., O Comentário de João, p. 251.

${ }^{96}$ Cf. SCHNACKENBURG, R., El Evangelio según San Juan, p. 156.

${ }^{97}$ LÉON-DUFOUR, X., op. cit., p. 35.

${ }^{98}$ BROWN, R., El Evangelio según Juan, pp. 421 e 433.

${ }^{99}$ BLANK, J., O Evangelho segundo João, p. 28.

${ }^{100}$ Autores que estão neste grupo: MOLLONEY, F., Il Vangelo di Giovanni, pp. 153-161; BOISMARD, M.-É.; LAMOUILLE, A., L'Évangile de Jean., pp. 165 e 171; CASALEGNO, A. Para que contemplem a minha glória., p. 159 et seq.; BEASLEY- MURRAY, G. R., John, WBC: v. 36., 1999, p. 75 et seq.; DODD, C. H., Interpretación del Cuarto Evangelio, pp. 424 e 434. LÉON-DUFOUR, X., op. cit., p. 34; GARCIA-VIANA L. F., El Quarto Evangelio: Historia, Teología y Relato, Madrid: San Pablo, 1997, p. 129 passim; GHEZZI, E., Come abbiamo ascoltato Giovanni, Bolonha: Digigraf, 2006, pp. 346; 373; FABRIS, R.; MAGGIONE, B., Os Evangelhos, p. 330 et seq.; CARREIRA DAS NEVES, J., Escritos de São João, Lisboa: UCE, 2004, p. 159; KÖNINGS, J., Evangelho segundo João, pp. 136-148. Para este exegeta o episódio chega a um fim abrupto no v. 47; MANNS, F., L'Évangile de Jean et la Sagesse, p. 144; FAUSTI, S., Una comunità legge il Vangelo di Giovanni, Bologna-Milano: EDB-Äncora, 2008, pp. 114123; Cf. MUÑOZ LEÓN, D., Evangelio segun san Juan. In LEVORATTI, A. (Dir.), Comentario Bíblico LatinoAmericano, Nuevo Testamento, Estella (Navarra): Verbo Divino, 2003, p. 620.

${ }^{101}$ Entre os quais: BLANK, J., O Evangelho segundo João, pp. 17 e 44; MARCHADOUR, A., L'Évangile de Jean, Commentaire pastoral, [S.n.]: Centurion, 1992, p. 93; KEENER, C., The Gospel of John, pp. 645-655.

102 Assim pensam os exegetas: GRASSO, S., Il Vangelo di Giovanni, p. 232; PANIMOLLE, S., L'evangelista Giovanni, Roma: Borla, 1985, pp. 53; 164; SIMOENS, Y., Selon Jean, v. 1, p. 245;
} 
3. Os exegetas que consideram o discurso de 5,1-47 inconcluso e sua continuação lógica o texto de 7,15-24 (5,19-30; 31-47; 7,15-24) se fundamentam em critérios temáticos (R. Schnackenburg, J. Caba, J. Zumstein, B. Lindars e S. Vidal). Além do problema da continuidade, eles apresentam variações na estrutura interna do discurso 5,19-47, especialmente na delimitação anterior: para R. Schnackenburg ${ }^{103}$, o discurso inicia-se a partir do v. 16 ou do v. 17.

4. E os exegetas que consideram o discurso de 5,19-47 uma unidade literária, fundamentando-a em critérios temáticos ${ }^{104}$.

\subsection{2.}

\section{A unidade temática}

Uma pluralidade de temas ${ }^{105}$ é indicada pelos estudiosos como desenvolvidos no discurso do capítulo 5. Alguns consideram certos temas relacionados ou mesmo interdependentes.

- Alguns veem o discurso como um processo (rib) e atribuem-lhe temas associados às controvérsias com os judeus, à apologia sobre a atuação de Jesus no sábado, à rejeição dos seus interlocutores e à perseguição por parte dos judeus, ao testemunho e acusação, e à defesa da comunidade diante das acusações com os devidos testemunhos em favor de Jesus". ${ }^{106}$

- Outros autores defendem que o discurso trabalha diversos temas relacionados ao Pai e ao Filho: O relacionamento de Jesus com seu Pai que faz sua vontade, a

WENGST, K., Il Vangelo di Giovanni, Brescia: Queriniana, 2005, pp. 209; 214; 221. Este último apresenta variação tanto na estrutura quanto na delimitação anterior (5,17-20; 21-30; 31-47).

${ }^{103}$ Entre eles: SCHNACKENBURG, R., El Evangelio según San Juan, v. 2, pp. 127-194; CABA, J., Cristo, Pan de Vida, p. 36. Este diz que o discurso interrompe o tema, sem aludir à reação dos ouvintes. Não comenta qual seja o tema. ZUMSTEIN, J., O Evangelho de João In MARGUERAT, D. (Org.)., Novo Testamento, p. 441; LINDARS, B., The Gospel of John. NCBC, pp. 218-233; VIDAL, S., Los Escritos Originales de la Comunidad del Discípulo Amigo de Jesus, 1997, p. 498. Para estes dois últimos o início seria partir do v. 19. Porém este último, além do acréscimo de $7,15-24$, o divide em três partes $5,19-24 ; 25-29$; 30-47; e S. Vidal ${ }^{103}$ considera-o incompleto (+ 7,15-24); no entanto, diz que a estrutura de 5,19-47 não apresenta divisão.

${ }^{104}$ BARRET, C. K., El Evangelio según San Juan, p. 389; BLANCHARD, Y-M., São João, São Paulo: Paulinas, 2004, p. 48; GHIBERT, G., Opera Giovannea, Torino: Elledici, 2003, pp. 35 e 41; GUILDING, A., The Fourth Gospel and Jewish Worship, p. 70; KÜMMEL, G., Introdução ao Novo Testamento, pp. 275-276; MLAKUZHYL, G., The Christocentric Literary Structure of the Fourth Gospel, pp. 217 e 104, muito embora este apresente variação no versículo da delimitação anterior: 5,14-47.

${ }^{105}$ Para melhor clareza, verificar o anexo I (tabela n. 1), que contém todos os temas e seus autores individualizados.

${ }^{106}$ MATEOS, J.; BARRETO, J., O Evangelho de São João, pp. 243; 267; GHEZZI, G., op. cit., pp. 346 e 373; SLOYAN, G., Giovanni, 2008, pp. 109-112; KÖNINGS, J., op. cit., pp. 139-148; GARCIA-VIANA., op. cit., pp. 129-131. 
obra conjunta do Filho e do Pai, o testemunho do Pai em favor de Jesus" ${ }^{107}$; a reivindicação de Jesus e sua legitimidade ${ }^{108}$.

- Há os que defendem que a temática do discurso estaria relacionada à escatologia e apresentam temas que enfatizam o Filho como juiz escatológico que tem poder de vivificar e julgar ${ }^{109}$. Portanto, em Jesus se realiza o evento escatológico do dom da vida e do juízo, para o qual foi enviado com a autoridade do emissário celeste ${ }^{110}$.

- Há ainda os que atribuem temas referidos à revelação: $\mathrm{O}$ apelo à autorrevelação de Jesus com seu testemunho e prova de sua divindade seria a ênfase do tema que poderia ser sintetizado na revelação do mistério do Filho ${ }^{111}$.

\section{5 .}

\section{Conclusão}

Os argumentos que fundamentam a "teoria dos deslocamentos" mostram que esta questão está conectada com algumas hipóteses de identificação da "festa de 5,1 "; essas duas questões, por sua vez, apresentam elementos diretamente relacionados com a problemática da "diversidade temática do discurso de 5,19-47".

A pesquisa bibliográfica identificou o surgimento de um elemento bastante significativo que se configura como um dado novo: a existência de uma interdependência entre as três referidas questões. Porém, ela ainda aponta para mais além, quando constata que somente a problemática relativa à temática do texto de 5,19-47, está subjacente a todas elas. Sendo, portanto, determinante para a averiguação da raiz da questão que envolve o referido capítulo.

- Não seria o caso de investigar se as questões acima referidas estão realmente na dependência da unidade temática de Jo 5,19-47?

Se o primeiro versículo do capítulo 5: Meta. tauka hq eòrth. twh Voudai un kai . araegh Whsoi' ejj terosol una condensa duas informações que catalizaram a atenção de inúmeros e bons exegetas para este capítulo e estas demonstraram

\footnotetext{
${ }^{107}$ PANIMOLLE, S., op. cit., p. 53; LINDARS, B., op. cit., p. 227.

${ }^{108}$ WENGST, K., op. cit., p. 207-221; GRASSO, S., op. cit., p. 232; KÜMMEL, G., op. cit., p. 276.

${ }^{109}$ MOLONEY, F., op. cit., p. 153-161; BOISMARD, M.-É.; LAMOUILLE, A., op. cit., p. 165 e 171; BEASLEY-MURRAY, G., op. cit., p. 75-77; BLANK, J., op. cit., p. 44; WENGST, K. op. cit., pp. 207-221; LINDARS, B., op. cit., 224; SCHNACKENBURG, R., op. cit., p. 135.

${ }^{110}$ VIDAL, S., op. cit., p. 498; MLAKUZHYIL, G., op. cit., p. 217.

${ }^{111}$ PANIMOLLE, S., op. cit., p. 164; LÉON-DUFOUR, X., op. cit., pp. 34; 50.
} 
algumas formas de relação com o texto discursivo (vv. 19-47), não seria interessante buscar ler o versículo em questão $(5,1)$ como sinalizador de todo o capítulo? Não estaria o autor a pontuar "MÆa. tauła" para a necessidade de se ler o capítulo a partir do lugar (terosd una) para o qual Jesus subiu (amedh) e nas circunstâncias (è̀rth. twh Voudainn) nas quais ele irá apresentar seu projeto literário para este capítulo, ao invés de se procurar identificar isoladamente a festa ou debater sobre a geografia do capítulo sem relacioná-la com o texto em sua totalidade?

Por conseguinte, a disposição para este estudo se centrará na questão referente à unidade temática do discurso de Jo 5,19-47 que está imbricado com as outras questões. É nesse campo que se insere a presente pesquisa, a fim de oferecer uma leitura nova dos problemas antigos, a qual será indicada no próximo capítulo que tomará o método da pragamalinguística como uma chave interpretativa nova. 


\section{3 \\ Eixo metodológico}

\section{1.}

Pré-compreensão metodológica

O pressuposto básico da abordagem a ser aqui aplicada é que o texto ${ }^{112}$ objeto deste estudo seja considerado uma obra literária. A pragmalinguística é a parte da linguística que se ocupa com os sinais linguísticos como elementos da comunicação $^{113}$. As categorias da análise pragmalinguística se focalizam em primeiro lugar sobre a investigação do "mundo do texto", momento considerado essencial no processo de compreensão, para que finalmente aconteça uma apropriação do texto. Essa apropriação, que pode se efetuar de maneira individual ou comunitária e toma forma em diferentes domínios, contribui para fazer compreender melhor o texto em si. "Colocar-se em presença do texto e de seus leitores suscita uma dinâmica, pois o texto exerce irradiação e provoca reações" diz a Pontifícia Comissão Bíblica ${ }^{114}$. Segundo Simian-Yofre, o texto não é simplesmente um sistema fechado de sinais que funcionam quase independentemente de seu produtor e de seu destinatário, mas o ponto de contato entre ambos, o núcleo que libera a energia comunicativa ${ }^{115}$.

\section{2.}

\section{Perguntas fundamentais}

O que interessa ao estudo propriamente pragmalinguístico do texto é verificar como o autor estrutura e realiza sua atividade comunicativa. Uma vez

\footnotetext{
${ }^{112} \mathrm{O}$ texto literário veicula uma forma específica de comunicação que evidencia um uso especial do discurso, colocado a serviço da criação artística reveladora. (...) O fenômeno literário se efetiva na interrelação autor-texto-leitor. Cf. PROENÇA, D. F., A linguagem literária, São Paulo: Ática, 2009 , p. 30 e passim.

${ }^{113}$ Segundo Armengaud, a pragmática textual tenta decifrar por que e para que um texto foi redigido. Nessa busca ela considera interdependentes o conteúdo (ato locutório), a utilização (ato ilocutório) e o efeito do texto (ato perlocutório). Há três graus de pragmática: o primeiro corresponde ao estudo dos símbolos indexicais; o segundo, ao sentido literal e sentido comunicado; e o terceiro, à teoria dos atos de fala. Cf. ARMENGAUD, F., A pragmática, São Paulo: Parábola, 2006, p. 64 et seq.

${ }^{114}$ Cf. PCB., A interpretação da Bíblia na Igreja, 1994, p. 65.

${ }^{115}$ Cf. SIMIAN-YOFRE, H., Anacronia e sincronia: hermenêutica e pragmática In Id. (Org.). Metodologia do Antigo Testamento, São Paulo: Loyola, 2000, p. 159.
} 
que um texto resulta de um tipo específico de atividade verbal, constituída de elementos linguísticos de diversas ordens, para a consecução de determinado resultado, que é, ao mesmo tempo, o motivo dessa atividade, pode-se dispor do próprio texto para compreender sua motivação, finalidade e realização ${ }^{116}$. No interior do percurso do método pragmalinguístico, a análise do conteúdo global do texto consiste em estabelecer a rede de relações entre os elementos, em seus diferentes níveis, a partir da qual o sentido do texto se constrói. Questões como a da unidade temática, das intenções do autor, do estabelecimento de um plano literário prefixado, do processo estratégico de sua construção textual, de sua situação comunicativa, dos condicionamentos e expectativas do leitor e de sua relevância, devem alcançar resultados, por meio de diferentes ações, a partir do próprio texto.

\section{a) Qual o princípio de unidade a ser buscado?}

No processo metodológico da pragmalinguística o critério decisivo para se estabelecer a unidade de um determinado texto, enquanto unidade comunicativa, é a constatação da presença simultânea da pessoa de um único autor e do desenvolvimento de um tema de fundo, de maneira orgânica e completa ${ }^{117}$. O tema não está fora do texto: ele existe na consciência do autor; é uma concepção daquilo que o autor deseja exprimir. A questão temática está associada à unidade do texto.

Conforme I. Wolfgang, o autor, o texto e o leitor são intimamente interconectados em uma relação a ser concebida como um processo em andamento, que produz algo antes inexistente. Ao leitor cabe perguntar: que nos dizem essas palavras? De que modo o texto está articulado em unidade $?^{118}$. Ao enfrentar a questão da unidade, a aproximação comunicativa desloca então o acento dos elementos externos ao texto, quais sejam a identidade do autor real, as

\footnotetext{
${ }^{116}$ Cf. MORA PAZ, C. et al., Lectura pragmalingüística de la Biblia teoría y aplicación, Estella (Navarra): Verbo Divino, 1999, p. 27.

${ }^{117}$ Cf. ECO, U., Lector in fabula, São Paulo: Perspectiva, 2011, p. 46.

${ }^{118}$ Cf. WOLFGANG, I., O Jogo do texto, In LIMA, L. C. (Org.)., A Literatura e o leitor, Textos de Estética da recepção, Rio de Janeiro: Paz e Terra, 2011, p. 105.
} 
referências históricas e o processo redacional, para elementos internos ao texto atual $^{119}$.

\section{b) De que autor/leitor se fala?}

Os elementos essenciais de um texto pertencem à categoria de autor e de leitor. A questão da autoria do Quarto Evangelho é muito complexa. Durante várias décadas tornou-se o grande desafio dos estudiosos deste Evangelho. A crítica histórica e redacional se ocupou principalmente do autor empírico, obtendo resposta a respeito de um possível processo redacional anterior ao Evangelho ${ }^{120}$. Porém, no método pragmalinguístico, o termo autor não se refere ao autor do Evangelho, mas ao do texto em causa, ao qual U. Eco ${ }^{121}$ chama de autor-modelo, isto é, o sujeito da enunciação textual. Ao se considerar o texto de Jo 5,19-47 como um evento comunicativo, o problema se desloca do autor concebido em sua estrutura física e histórica para o autor entendido como "estratégia textual". Um dos recursos do método de análise da pragmalinguística, segundo Mora Paz ${ }^{122}$ é a interpretação do texto em seu contexto, a partir do texto mesmo, considerando-o como uma obra conjunta do autor e do leitor que o escritor tem em mente.

Por ser o texto obra de escritor e leitor, se podem reconstruir, através do próprio texto, as intenções do autor e os condicionamentos e expectativas do leitor, assim como também sua situação comunicativa. Daí que se fale do 'leitor implícito' e do 'autor implícito" ${ }^{123}$ no texto. Isto quer dizer que o tipo de leitura que se supõe neste método é do tipo "crítico-literário ${ }^{124}$.

Segundo a pragmalinguística, a "estratégia textual" identifica o autor do discurso com o sujeito da enunciação, assumindo a característica do emitente da mensagem aos leitores ${ }^{125}$ ou do autor-modelo ${ }^{126}$. Sua função de autor-modelo

\footnotetext{
119 Cf. OBARA, M. E., Le strategie di Dio. Dinamiche Comunicative nei Discorse Divini del Trito-Isaia, Roma: Pontificio Istituto Biblico, AnBib, n. 188, 2010, p. 17.

${ }^{120}$ Cf. BROWN, R., El Evangelio según Juan, v. 2, Madrid: Cristiandad, 1979, p. 36. Id. A comunidade do Discípulo Amado, São Paulo: Paulinas, 1984, p. 61.

${ }^{121}$ Cf. ECO, U., Lector in fabula, p. 45.

122 MORA PAZ, C. et al., Lectura pragmalingüística de la Biblia, p. 25.

123 Por "autor implícito" é designada a imagem do autor que o texto produz progressivamente no decorrer da leitura. Por "leitor implícito" entende-se aquele que o texto pressupõe e produz, aquele que é capaz de efetuar as operações mentais e afetivas, exigidas para entrar no mundo do relato e assim responder a ele da maneira visada pelo autor real, através do autor implícito. Por autor real se entende a pessoa que compôs o discurso. Cf. PCB., A interpretação da Bíblia na Igreja, p. 51.

${ }^{124}$ MORA PAZ, C., op. cit., p. 27.

${ }^{125}$ Como sugere Umberto Eco, neste estudo se falará em leitor em vez de destinatário e usar-se-á, indiferentemente, emitente e autor, para definir o produtor do texto. Cf. ECO, U., op. cit., p. 46-47.
} 
relativiza o interesse pelo autor real ou empírico. Exatamente esta reconstrução do autor-modelo constitui o princípio que legitima a operação interpretativa dos textos. O autor-modelo ${ }^{127}$ é o único que pode oferecer ao leitor a chave interpretativa do texto.

- Mas que leitor?

Assim responde U. Eco:

Para organizar a própria estratégia textual, o autor deve referir-se a uma série de competências $^{128}$ (expressão mais vasta que conhecimento de códigos) que confiram conteúdo às expressões que usa. Ele deve aceitar que o conjunto de competências a que se refere é o mesmo a que se refere o próprio leitor. Por conseguinte, preverá um leitor-modelo, capaz de cooperar para atualização textual, como ele, o autor, pensava, e de movimentar-se interpretativamente conforme ele se movimentou gerativamente $^{129}$.

Os teóricos da literatura distinguem entre autor e leitor "empírico" ou "real", e autor e leitor implícito ${ }^{130}$. Esta distinção é importante para a própria compreensão do processo comunicativo que se estabelece no texto. Na realidade o autor e o leitor, com os quais entra em contato um leitor empírico que lê o texto, não são aqueles reais, mas, antes de tudo, o autor e o leitor presentes no relato; são figuras literárias, inseridas no texto ${ }^{131}$. É ainda U. Eco que ajuda a esclarecer:

Fica claro, portanto, que, doravante, toda vez que usamos termos como autor e leitor-modelo, sempre entenderemos, em ambos os casos, tipos de estratégia textual. O leitor-modelo constitui um conjunto de condições de êxito ${ }^{132}$,

\footnotetext{
${ }^{126}$ Cf. Ibid., p. 46 et seq.

${ }^{127} \mathrm{O}$ termo "autor-modelo" foi assumido por Umberto Eco quando, ao analisar as estratégias textuais do processo comunicativo, referiu-se ao emitente da mensagem - ao sujeito empírico do ato de enunciação em questão -, como autor, ou seja, para ele o autor é aquele que é textualmente manifestado como o emitente da mensagem, o que assume o papel actancial de emitente (eu $=\mathrm{o}$ sujeito deste enunciado). Cf. ECO, U., op. cit., p. 44 et seq.

${ }^{128}$ Segundo Oliveira, M., "Competência linguística" é a capacidade de um falante ideal de dominar um sistema abstrato de regras gerativas de linguagem. Parte-se do fato de que falante e ouvinte usam sentenças, em seus proferimentos, para entrar em entendimento a respeito de estados de coisa. A própria estrutura das unidades elementares da sentença, isto é, dos atos de fala, revela isso (...). OLIVEIRA, M. A., Reviravolta linguístico-pragmática na filosofia contemporânea, São Paulo: Loyola, 2006, p. 296 et seq.

${ }^{129}$ Cf. ECO, U., Lector in fabula, p. 39.

${ }^{130}$ Cf. Ibid., p. 44 et seq.

131 Cf. GRILLI, M. Pragmatica $e$ analisi del texto. Disponível em: http://www.evangeliumetcultura.org/IT/Pragmatica\%20e\%20analisi\%20del\%2Otesto.php. Aces sado em 14 de maio de 2012.

${ }^{132}$ As condições de êxito se referem a uma série de competências que prevê no leitor-modelo capacidades de cooperar para a atualização do texto; significa esperar que ele seja capaz de mover o texto, de modo a reconstruí-lo. Toda obra prevê o seu leitor ideal.
} 
textualmente estabelecidas, que devem ser satisfeitas para que um texto seja plenamente atualizado no seu conteúdo potencial" ${ }^{\prime 33}$.

Se o autor espera contar, não com qualquer tipo de leitor, mas com um leitor que disponha de muito tempo, que não seja apressado nem livre para criar o sentido que lhe convém, que tenha perspicácia associativa, ele está construindo o próprio leitor-modelo, com condições de possibilidades de se interessar pela obra a ele dirigida ${ }^{134}$. Nesta perspectiva, o texto resulta de uma série de escolhas de ordem literárias e teológicas, uma vez que o autor-modelo, pressupondo o leitorimplícito, partilha com ele conhecimentos e valores, cuja intenção poderá ser encontrada nos caminhos através dos quais o autor-modelo conduz o leitor no interior do texto.

\section{c) Como definir uma organização?}

A questão da "estrutura" de um texto, isto é, de sua organização, pressupõe princípios organizatórios que confiram singularidade ao conjunto. A análise da estrutura do texto sob a ótica do plano de sua comunicação requer um procedimento próprio do seu campo metodológico ${ }^{135}$. Conforme a pragmalinguística, a categoria que orienta e organiza o texto é o tema, ou seja, o tema classifica e ordena a realidade significante, estabelecendo relações e dependências. O tema é um investimento semântico, de natureza puramente conceptual. Consequentemente, o tema é circundado por seu horizonte ${ }^{136}$.

$\mathrm{Na}$ abordagem comunicativa parte-se da observação de como o discurso está desenvolvendo progressivamente seu tema de fundo ${ }^{137}$. A progressão textual diz respeito aos procedimentos linguísticos por meio dos quais se estabelecem, entre segmentos do texto (enunciados, partes de enunciados, parágrafos e mesmo sequências textuais), diversos tipos de relações semânticas e/ ou pragmáticodiscursivas, à medida que faz o texto progredir ${ }^{138}$. O autor estrutura o seu texto de forma seletiva. Por isso, na seletividade do processamento textual, o tema desempenha papel relevante na escolha do gênero, do meio, da perspectiva, da modalidade, bem como no emprego de recursos estilísticos etc.; todos os aspectos

\footnotetext{
${ }^{133}$ Cf. ECO, U., op. cit., 2011, p. 45.

${ }^{134}$ Cf. Ibid., p. 43.

${ }^{135}$ Cf. LIMA, L. C. (Org.)., A literatura e o leitor, p. 169.

${ }^{136}$ Cf. Id., Ibid.

${ }^{137}$ Cf. OBARA, E., Le strategie di Dio, p. 23.

${ }^{138}$ Cf. KOCH, I. V., Desvendando os segredos do texto, São Paulo: Cortez, 2011, p. 121.
} 
interrelacionam-se com a arquitetura textual, a serviço do que é comunicado ${ }^{139}$. A aparente descontinuidade ou incongruência textual nada mais é que o resultado de uma mudança de estratégia de convencimento, posta em ação pelo autor. Em síntese, a organização de um texto tem o seu próprio princípio de significação, não no simples levantamento de dados - esse de natureza lexical, redacional ou outro - mas na sua dinâmica e função comunicativa ${ }^{140}$.

\section{3. \\ O percurso metodológico}

Traçar o percurso a ser empreendido nesta nova forma de aproximação ao texto, neste momento, é fundamental. Ao se aplicar o método da pragmalinguística ao presente estudo, deve-se apresentar o esquema metodológico, que corresponda ao processo analítico tal como ele se realiza no texto, e descrevê-lo através de um número limitado de elementos que constantemente reaparecem em novas combinações. Segundo M. Grilli ${ }^{141}$, a pragmática intervém fundamentalmente no processo de compreensão de um texto. Este método se move preferentemente no campo da sincronia, mas está também aberto à diacronia ${ }^{142}$.

Para dar uma resposta adequada à questão como isso ocorre, deve-se refletir sobre a noção de "texto" e de "processo comunicativo". Assim sendo, na primeira fase, deve-se partir do princípio homogêneo da análise que é a definição do próprio termo "discurso" e da identificação de suas principais características, bem como dos outros elementos que determinam a metodologia e a sua estrutura ${ }^{143}$.

\footnotetext{
${ }^{139}$ Cf. Id. Introdução à linguística textual, São Paulo: Martins Fontes, 2009, p. 172 et seq.

${ }^{140}$ Cf. OBARA, E., op. cit., p. 19.

${ }^{141}$ Cf. GRILLI, M. artigo Pragmatica $e$ analisi del texto. Disponível em: http://www.evangeliumetcultura.org/IT/Pragmatica\%20e\%20analisi\%20del\%2Otesto.php. Aces sado em 14 de maio de 2012.

${ }^{142}$ Em especial aos métodos histórico-críticos; pode-se assimilá-los e aperfeiçoá-los com uma concepção mais ampla da comunicação textual. Cf. MORA PAZ, C. et al., Lectura pragmalingüística de la Biblia, teoría y aplicación, p. 24.

${ }^{143}$ Para desenvolvê-lo, por um lado, seguiremos o esquema metodológico da pragmalinguística aplicado à Bíblia, utilizado por Elzbieta Obara; e por outro, a teoria da análise de linguística textual de Ingedore Koch. Cf. OBARA, E., op. cit., p. 19; Cf. KOCH, I. V., Introdução à linguística textual, e outras obras da mesma autora citadas no percurso da análise textual.
} 


\subsection{1.}

\section{A natureza da categoria "discurso"}

$\mathrm{Na}$ linguística textual o conceito de texto/discurso ${ }^{144}$ varia conforme a orientação teórica adotada, dependendo da ciência que o utiliza, mesmo no interior das ciências da linguagem. Há definições mais genéricas ${ }^{145}$ e outras mais complexas ${ }^{146}$. Há textos singulares e hipertextos ${ }^{147}$. O texto bíblico é por natureza e essência intertextual ${ }^{148}$. Os gramáticos consideram o texto um enunciado, verbal ou não, produzido em uma situação comunicativa, que apresenta unidade de sentido e intencionalidade discursiva ${ }^{149}$. Nesta concepção, a unidade superior chamada texto está composta por um conjunto de frases que têm em comum o mesmo tema e a mesma situação comunicativa, capaz de construir sentido. Porém, quando se considera no enunciado, não apenas o que é dito, mas também os diversos elementos da situação - quem são os interlocutores, em que momento e lugar ocorre a interação, com que finalidade, o que o locutor pensa do ouvinte/leitor e vice-versa, etc, - tem-se "o discurso" ${ }^{150}$. O texto/discurso é uma atividade interacional, visto que os interactantes, de maneiras diversas, se acham envolvidos na atividade de produção textual. O texto é, portanto, a realização de um processo comunicativo entre o autor e o que o recebe.

Por conseguinte, quando se trabalha sobre um texto, antes de tudo deve-se tomar em consideração o tecido constitutivo, porque nele se baseia a

\footnotetext{
${ }^{144} \mathrm{~A}$ distinção entre as duas categorias texto/discurso é devida frequentemente à particular exigência de um determinado ramo das diversas ciências e ao seu método. O próprio conceito de texto depende das concepções que se tenha de língua e de sujeito da enunciação. Cf. KOCH, I. V., O texto e a construção de sentidos, São Paulo: Contexto, 2011, p. 25.

${ }^{145}$ Tais como: "O discurso é um ato de comunicação completo". Esta definição, segundo Koch, é muito genérica para ser satisfatória. Não explica, por exemplo, a que unidade linguística corresponde, nem qual a sua situação comunicativa. Esse termo em sua acepção corrente não é suscetível de uma definição geral. Cf. KOCH, I. V., op. cit., 2011, p. 27. Ou ainda segundo Alonso Schökel: "O texto é uma obra literária, um sistema preciso de palavras, ordenado e significativo, uma estrutura ou um sistema de estruturas, um ato realizado no tempo, é uma potencialidade que pede para ser atualizada". Cf. SCHÖKEL, A., A Palavra inspirada, 1992, p. 171.

${ }^{146} \mathrm{O}$ texto da literatura para Proença "é um objeto de linguagem ao qual se associa uma representação de realidades físicas, sociais e emocionais mediatizadas pelas palavras da língua na configuração de um objeto estético. O discurso literário traz, em certa medida, a marca da opacidade: abre-se a um tipo específico de descodificação ligado à capacidade e ao universo cultural do autor". Cf. PROENÇA, D. F., A linguagem literária, São Paulo: Loyola, 2009, p. 7 et seq.

${ }_{147}$ Cf. KOCH, I. V., Desvendando os segredos do texto, p. 67.

${ }^{148}$ MANNS, F., L'Évangile de Jean et la Sagesse, Studium Biblicum Franciscanum, Analecta, n. 62,2003 , p. 6 et seq.

${ }^{149}$ CEREJA, W. R.; MAGALHÃES, T. C., Gramática, texto, reflexão e uso, São Paulo: Atual, 2012, p. 21.

${ }^{150}$ Id., Ibid.
} 
comunicação, o discurso ${ }^{151}$. A distinção entre os dois termos acontece, portanto, em um contexto de análise do processo comunicativo do enunciado, tendo em vista a rede de relações em ordem a uma comunicação, à relação interagente entre falantes. Pode-se compreender o texto/discurso em sua natureza pragmática como uma sequência de atos de fala ${ }^{152}$ que potencia uma situação comunicativa.

Constata-se que nas concepções do termo "discurso", acima referidas, há a presença de elementos constantes e interdependentes, tais como a de que o discurso é um enunciado unitário com função comunicativa, com a presença de um único locutor (emitente), tematicamente orientado e com potencial ilocucionário $^{153}$. A definição do discurso através de sua índole e função comunicativa exige um ulterior esclarecimento dos conceitos e do procedimento metodológico que concerne à própria comunicação. Por conseguinte a definição e índole comunicativa do discurso implicam características fundamentais: unidade, completude, coesão e coerência ${ }^{154}$.

\subsection{2.}

\section{Unidade, completude, coesão e coerência do "discurso"}

\section{a) Unidade}

A unidade de um discurso é, fundamentalmente, determinada pela existência de um único autor e de um único tema de fundo articulado por meio dos diversos componenetes temáticos que emergem no texto ${ }^{155}$. É o tema que estabelece a unidade textual, sendo, por isso mesmo, seu elemento mais abrangente. Na análise da unidade de um discurso deve-se partir de seu principal elemento de coesão que é o tema. O tema central ou de fundo é o assunto principal sobre o qual versa o

\footnotetext{
${ }^{151}$ No presente escrito se adotará só em sentido técnico o termo "discurso" (o discurso de João) segundo as características a serem evidenciadas, considerando que possam ser usados, quer seja "discurso", quer seja "texto", em uma acepção mais ampla, por compreender que do ponto de vista linguístico, todo texto é um grande enunciado unitário, um discurso.

${ }^{152}$ Este assunto será aprofundado ocasionalmente. Segundo Armengaud, o ponto de partida da teoria clássica dos "atos de fala" é a seguinte convicção: a unidade mínima da comunicação humana não é nem a frase nem qualquer outra expressão. É a realização (performance) de alguns tipos de ato. A teoria dos atos de fala é um estudo sistemático da relação entre os signos e seus intérpretes. Trata-se de saber o que fazem os intérpretes-usuários, que atos eles realizam pelo uso de certos signos. O pioneiro nessa convicção foi o filósofo de Oxford, John L. Austin. Cf. ARMENGAUD, F., A pragmática, p. 99.

${ }^{153}$ Cf. SIMIAN-YOFRE, H. (Org.), Anacronia e sincronia: hermenêutica e pragmática In Id. Metodologia do Antigo Testamento, São Paulo: Loyola, 2000, p. 159.

${ }^{154}$ Cf. OBARA, E., Le strategie di Dio, p. 22.

${ }^{155}$ Cf. Id., Ibid.
} 
discurso. A seguir o tema de fundo da obra vai se espargindo através de certo número de temas secundários, ou seja, de motivos. Do ponto de vista do conteúdo, é importante distinguir os motivos do tema central. Por isto é necessário falar do "tema de fundo" e do "tema particular", que correspondem respectivamente, aos termos: "tema" e "motivo" 156 . Os motivos apresentam aspectos particulares relacionados com o tema central e, mesmo que eles sejam bem desenvolvidos, cada um deles não esgota o tema central. Este é o fruto da interrelação entre os diversos motivos presentes no discurso. Os motivos podem adquirir, no curso da comunicação, um desenvolvimento amplo e complexo. Estes se manifestam, de fato, de maneira mais evidente, na superfície do discurso - graças, por exemplo, à evocação dos elementos recorrentes, de referência a certas realidades, objetos, pessoas, determinados termos ou imagens.

A reiteração do "motivo" não tem então uma função ornamental, mas contribui a construir uma linha dos significados. O motivo, de fato, de uma parte permanece reconhecível ao leitor ou ouvinte em cada uma das suas aparições e, por outra, modificando-se e articulando-se no curso da comunicação, aumenta a sua potencialidade informativa e persuasiva. A este propósito nota-se também a função da ordem de comparação dos motivos, que não deve ser sempre igual no suceder dos discursos; ou melhor, antes, lhe modifica em nova combinação revelando diversas perspectivas e facetas renovadas da mensagem.

No conjunto, a finalidade do recurso aos conceitos dos "temas" e "motivos" é a de sublinhar a relevância e interdependência de ambas as categorias, no modo de tratar o discurso. O tema de um discurso não se desenvolve senão através da articulação de todos os motivos que o compõem: não é, portanto, possível determinar o tema sem individuar os motivos e sem analisar quer individualmente quer na sua articulação recíproca. A disposição da matéria temática de um discurso em um número limitado de motivos torna mais clara e orgânica a exposição do argumento e aumenta a sua receptividade. Esta é a razão pela qual o discurso deve ser considerado como unidade textual na qual se devem descobrir todos os motivos constitutivos do tema.

${ }^{156}$ Cf. Ibid., p. 23. 


\title{
b) Completude
}

A análise do tema do discurso atravessa a articulação dos motivos que o compõem e permite, enfim, a verificabilidade de sua completude, porque um texto é completo quando contém aquilo que serve para compreender o tema de fundo. Todavia, tal verificação pode ser completa somente ao fim da análise que compreende o conteúdo do discurso e a sua função pragmática em sua etapa particular e no seu conjunto ${ }^{157}$. Um texto atinge sua completude quando apresenta todos os motivos necessários a esclarecer seu tema central. Chega-se a verificar se o texto é completo quando, no final da análise dos diversos motivos que o compõem, alcança-se a compreensão da totalidade do discurso e a função de cada um dos motivos apresentados em relação ao todo ${ }^{158}$.

A delimitação de um texto diz respeito à sua unidade temática e coesão, que constituem duas de suas características fundamentais. Por conseguinte, para delimitar um texto deve-se partir da determinação da extensão de sua comunicação - onde começa e onde termina. Sobre este aspecto é útil considerar o que diz Obara:

\begin{abstract}
$\mathrm{Na}$ exegese bíblica, segundo o tipo de texto e da metodologia utilizada, existem diversos critérios para a delimitação de cada unidade. No presente estudo a delimitação do discurso dependerá dos dados formais comumente reconhecidos, mas, sobretudo daquelas indicações específicas que determinam o texto na qualidade estritamente comunicativa. Em particular, a presença de uma nova unidade comunicativa pode ser marcada de uma nova faceta temática em relação à outra trazida no fim do discurso precedente, pela utilização de uma estratégia comunicativa, de uma particular finalidade persuasiva, da focalização de um específico grupo dos referentes, das mudanças do papel do locutor ${ }^{159}$.
\end{abstract}

A seguir, o texto deverá ser submetido à análise de sua coesão, que requer analisar a articulação interna do discurso, a sua construção e, conforme a pragmalinguística, é prioritário que essa análise parta da consideração do texto em sua qualidade comunicativa. A unidade e a completude do texto têm, então, um nexo inseparável com a coesão e a coerência ${ }^{160}$.

\footnotetext{
${ }^{157}$ Cf. OBARA, E., Le strategie di Dio, p. 23.

${ }^{158}$ NAY, R. Jahweh im Dialog. Kommunikationsanalytische Untersuchung von Ez 14,1-11, unter Berücksichtigung des Dialogischen Rahmens in Ez 8-11 und Ez 20. Roma: Pontificio Istituto Biblico, 1999, p. 14.

${ }^{159}$ OBARA, E., op. cit., p. 21

${ }^{160}$ Cf. NAY, R., op. cit., p. 20.
} 


\section{c) Coesão}

A coesão é o fenômeno que diz respeito ao modo como os elementos linguísticos presentes na superfície textual se encontram interligados entre si, por meio de recursos também linguísticos, formando sequências veiculadoras de sentidos $^{161}$. Os fatores de coesão são aqueles que dão conta da sequencialidade superficial do texto, isto é, os mecanismos formais de uma língua que permitem estabelecer, entre os elementos linguísticos do texto, relações de sentido. Não se refere ao significado do discurso, mas a sua construção ${ }^{162}$. É por meio de mecanismos, os quais têm por função precípua estabelecer relações textuais, que se vai tecendo o texto.

Os recursos coesivos são classificados em dois grandes grupos, responsáveis pelos dois grandes movimentos de construção do texto: a coesão remissiva e/ou referencial (remissão/referência a elementos anteriores - correferência de caráter anafórico $^{163}$ e catafórico), e a coesão sequencial. Esta diz respeito aos procedimentos linguísticos por meio dos quais se estabelecem, entre segmentos do texto (enunciados, partes de enunciados, parágrafos e mesmo sequências textuais), diversos tipos de relações semânticas e /ou pragmático-discursivas, à medida que faz o texto progredir de forma a garantir a continuidade do sentido. Esta interdependência é garantida, em parte, pelo uso de diversos mecanismos de sequenciação existentes na língua e, em parte, pelo que se denomina progressão tópica.

Concluindo, pode-se afirmar que o conceito de coesão textual diz respeito a todos os processos de sequencialização que asseguram (ou tornam recuperável) uma ligação linguística significativa entre os elementos que ocorrem na superfície textual.

\footnotetext{
${ }^{161}$ Cf. KOCH, I. V., O texto e a construção de sentidos, 2011, p. 45.

${ }^{162}$ Cf. Id., A coesão textual, São Paulo: Contexto, 2010, pp. 11. 15.

${ }^{163} \mathrm{Nem}$ sempre o referente de uma forma coesiva vem expresso no texto, trata-se, em primeiro lugar das anáforas ditas associativas semânticas ou profundas (baseadas em relações léxicoestereotípicas, de ingrediência, representadas na memória em forma de modelos cognitivos) e anáforas indiretas, que exigem um grau de inferenciação mais complexo. Cf. $\mathrm{KOCH}$, I. V., Introdução à linguística textual, p. 38 et seq.
} 


\section{d) Coerência}

A coerência é outra característica do discurso e concerne ao modo como os elementos subjacentes à superfície textual vêm a constituir, na mente dos interlocutores, uma configuração veiculadora de sentidos. A ligação lógica entre as partes, ou seja, a conexão entre os conteúdos presentes no texto é resultado de uma construção feita pelos interlocutores, numa situação de interação dada, pela atuação conjunta de uma série de fatores de ordem cognitiva, sócio cultural e interacional $^{164}$. A coerência está diretamente ligada à possibilidade de se estabelecer um sentido para o texto, ou seja, ela é o que faz com que o texto faça sentido para os leitores, devendo, portanto, ser entendida como um princípio de interpretabilidade, ligada à inteligibilidade do texto numa situação de comunicação e à capacidade que o receptor tem para calcular o sentido deste texto. Este sentido deve ser do todo, pois a coerência é global ${ }^{165}$.

A coerência textual decorrre de uma multiplicidade de fatores das mais diversas ordens: linguísticos, discursivos, cognitivos, culturais e interacionais ${ }^{166}$. A relação que tem de ser estabelecida pode ser não só semântica (entre conteúdos), mas também pragmática, entre os atos de fala, ou seja, entre as ações que realizamos ao falar (por exemplo: jurar, ordenar, advertir, asseverar, pedir, ameaçar, prometer). A coerência se daria entre os atos de fala que as proposições realizam $^{167}$. Na aproximação comunicativa, a coerência pragmática condiciona fortemente a consideração de outros componentes do discurso, porque é o princípio último de coerência do próprio discurso ${ }^{168}$.

A distinção entre coesão e coerência, diz Ingedore $\operatorname{Koch}^{169}$, não deve ser estabelecida de maneira radical, consideradas como dois fenômenos independentes, pois nem sempre a coesão se estabelece de forma unívoca entre os elementos presentes na superfície textual. Desta maneira, sempre que se faz necessário um cálculo do sentido, com recurso a elementos contextuais - em

\footnotetext{
${ }^{164}$ Cf. KOCH, I. V., O texto e a construção de sentidos, p. 52.

${ }^{165}$ Cf. Id; TRAVAGLIA, L. C., A coerência textual, São Paulo: Contexto, 2011, p. 21.

${ }^{166}$ Cf. Ibid., p. 71.

167 Segundo Koch uma proposição é definida como a representação linguística de um estado de coisas por meio de um ato de referência e um ato de predicação, daí a expressão conteúdo proposicional. Cf. Ibid., p. 21.

${ }_{168}$ Cf. OBARA, E., Le strategie di Dio, p. 26.

${ }^{169} \mathrm{Cf}$. KOCH, I. V., Introdução à linguística textual, p. 46.
} 
particular os de ordem sociocognitiva e interacional - já nos encontramos no domínio da coerência.

\subsection{3.}

\section{Atividades da ação comunicativa do discurso}

A atividade comunicativa tem como finalidade produzir um efeito: transmitir concepções e induzir reações emocionais ou motoras. Mais precisamente, o emissor da comunicação (o produtor atual do texto) busca atrair o destinatário a suas próprias concepções, convicções e finalidades. A atividade comunicativa não se identifica com a finalidade, mas é o meio para alcançar uma finalidade.

No texto, quem fala/escreve se encontra com quem escuta/lê; porém o texto não apenas contém significados, mas é um agente operativo. Comunicar uma informação é somente uma das funções da linguagem e, às vezes, se revela como insuficiente para explicar um enunciado. Há diversas funções da linguagem e todas devem ser consideradas ${ }^{170}$.

A força do método da pragmalinguística, conforme comenta Mora Paz, está exatamente na consideração das diversas funções da linguagem.

\section{a. A comunicação}

Por ser uma unidade linguística em ordem a uma comunicação, na mente do emitente, o texto corresponde a uma determinada intenção comunicativa e se instala no interior de uma estratégia de comunicação. O processamento textual é estratégico. Em estreita relação com a estratégia se coloca o aspecto funcional, isto é, a finalidade própria da comunicação. A comunicação, segundo E. Obara ${ }^{171}$ é um processo complexo, no qual diversos elementos interagem entre si; a modalidade segundo a qual acontece tal interação é descrita pelos estudiosos através dos modelos da comunicação. Um modelo já consagrado é o esquema

\footnotetext{
${ }^{170}$ Cf. MORA PAZ, C., et al., Lectura pragmalingüística de la Biblia, p. 27.

${ }^{171}$ Cf. OBARA, E., op. cit., p. 29.
} 
linguístico de Roman Jakobson ${ }^{172}$ que considera a comunicação o resultado da interação de seis elementos ${ }^{173}$ :

O remetente envia uma mensagem ao destinatário. Para ser operante, a mensagem requer em primeiro lugar o referimento a um contexto (...), contexto que possa ser compreendido pelo destinatário e que seja verbal, ou susceptível de verbalização; em segundo lugar exige um código inteiramente, ou ao menos parcialmente, comum ao remetente e ao destinatário (ou em outros termos, à codificação e decodificação da mensagem); enfim um contato, um canal físico e uma conexão psicológica entre o remetente e o destinatário, que permite estabelecer e manter a comunicação. Estes diversos fatores que não se pode suprimir da comunicação verbal podem ser representados esquematicamente como segue:

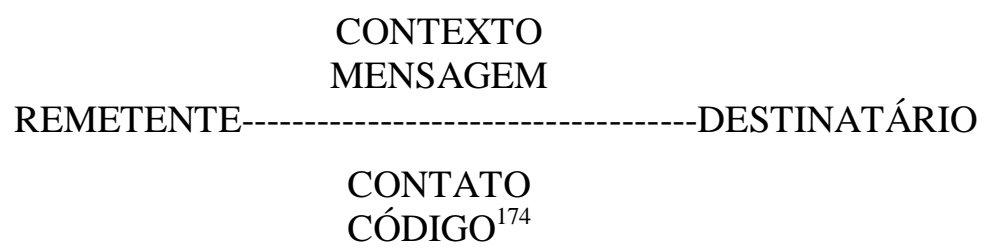

O mérito deste modelo consiste, sobretudo, em atribuir um papel fundamental aos participantes, os quais entram em um processo comunicativo complexo distinto dos já vivenciados: conhecimento, expectativa, atos de vontade, junto a outros elementos contextuais e situacionais que são características da comunicação $^{175}$. Reforçando esse aspecto participativo diz Simian-Yofre:

Se o texto é constitutivo do processo de comunicação, o que requer a presença cooperante do destinatário, convertido então em receptor, segue que não existe verdadeiramente texto sem comunicação, nem comunicação sem receptor ${ }^{176}$.

Para a consideração do texto em uma situação comunicativa e para responder aos desafios de uma moderna hermenêutica, a leitura do texto deve refletir a tensão e respeitar a intenção com referência às quais nasceu o texto, isto é, se a leitura atual do texto cria tensão análoga à criada pela resposta do texto em sua situação original, aceitando continuar o processo comunicativo sem interrompê-lo definitivamente ${ }^{177}$. O problema se põe, sobretudo, para os textos antigos. Em todo caso, como entrar em um processo comunicativo, que reduz a

${ }^{172}$ DUBOIS, J., Verbete "comunicação" In DUBOIS, J. (Org.)., Dicionário de Linguística, São Paulo: Cultrix, 1993, pp. 129-132.

${ }^{173}$ Estes termos do modelo de comunicação de R. Jakobson hoje já foram substituídos por outros como locutor/locutário; enunciador/enunciatário.

${ }^{174}$ Cf. OBARA, E., Le strategie di Dio, p. 30.

${ }_{175}^{175}$ Cf. Ibid., p. 30.

176 SIMIAN-YOFRE, H. (Org.). Anacronia e sincronia: hermenêutica e pragmática In Id. Metodologia do Antigo Testamento, p. 166.

${ }^{177}$ Cf. Ibid., p. 167. 
distância e permite ao leitor entrar no horizonte do outro, é o problema de toda autêntica comunicação ${ }^{178}$. Para M. Grilli, a autêntica leitura de um texto é, de qualquer maneira, intrigante.

Se o mundo que eu desejo conhecer é afim ao meu, a compreensão é imediata; se aquele mundo é distante, o texto que o descreve para mim deve ser analisado e tornado transparente mediante a análise das pressuposições e do seu sentido oculto. Sobretudo, neste segundo caso, a comunicação é um processo laborioso, porque significa abolir a distância e criar afinidade ${ }^{179}$.

Conforme Alonso Schökel ${ }^{180}$, a leitura de um texto como obra literária deixa perceber o intuito de proclamar a mensagem, de influenciar os leitores, já que a finalidade de sua atividade literária é a comunicação.

\section{b. A intencionalidade}

$\mathrm{O}$ autor de um texto tem, necessariamente, determinados objetivos ou propósitos que vão desde a simples intenção de estabelecer ou manter o contato com o receptor até a de levá-lo a partilhar de suas opiniões ou a agir ou comportar-se de determinada maneira. Assim, a intencionalidade refere-se ao modo como os emissores usam textos para perseguir e realizar suas intenções, produzindo, para tanto, textos adequados à obtenção dos efeitos desejados ${ }^{181}$. Por conseguinte, deve-se, também, considerar a influência do ouvinte na geração do texto. Para isso, o locutor usa recursos para atrair ou afastar o destinatário de uma ideia, um comportamento etc; ou para ensiná-lo sobre o que deve ou não ser feito ou pensado; ou para indicar-lhe o que lhe é ou não favorável.

Assim diz I. Koch:

Se aceitamos como verdade que não existem textos neutros, que há sempre alguma intenção ou objetivo da parte de quem produz um texto, e que este não é jamais uma cópia do mundo real, pois o mundo é recriado no texto através de nossas crenças, convicções, perspectivas e propósitos, então somos obrigados a admitir que existe sempre uma argumentatividade subjacente ao uso da linguagem. A intencionalidade tem relação estreita com o que se tem chamado de argumentatividade ${ }^{182}$.

178 Cf. GRILLI, M. Comunicação e pragmática. Disponível em: http://www. Evange liumetcultura.org/IT/Comunicazione\%20e\%2Pragmática. php. Acessado em 14 de maio de 2012.

${ }^{179}$ Cf. Ibid.

${ }^{180}$ Cf. SCHÖKEL, A., A Palavra inspirada, p. 169.

${ }^{181}$ Cf. KOCH, I. V.; TRAVAGLIA, L. C., A coerência textual, p. 97.

${ }^{182}$ Cf. Ibid., p. 98. 
A argumentatividade, ainda segundo Koch, manifesta-se nos textos por meio de uma série de marcas ou pistas que vão orientar os seus enunciados no sentido de determinadas conclusões, isto é, que vão determinar-lhes a orientação argumentativa, segundo uma perspectiva dada ${ }^{183}$. Com base nos estudos sobre a análise de discursos e narrativas, identificam-se as influências que o locutor pretende exercer sobre os locutários. Podem-se individualizar quatro tipos de intervenção potencialmente realizável de um locutor em confronto com o locutário: incitar, impedir, estimular reações ambivalentes (incitações e inibições ao mesmo tempo) e neutralizar, isto é, levar à indiferença ${ }^{184}$. Por seu lado, no exercício da influência, o locutor se baseia sobre a exploração das principais causas que possam ter caráter hedonístico, ético ou pragmático. Sob esse ponto de vista diz E. Obara:

A influência de obrigação e proibição explora as causas éticas, porque agem respectivamente, inculcando o sentido da obrigação, a cuja execução equivale a adequar-se, ou ao sentido da proibição, a cuja violação equivale a achar-se em erro. A influência conselheira e a dissuasiva se fundam sobre a razão pragmática, despertando a consciência de vantagens ou desvantagens que resultariam no momento em que um determinado acontecimento viesse ou não a realizar-se ${ }^{185}$.

O esforço da pragmalinguística consistiria então em adaptar as estruturas linguísticas às exigências da situação comunicativa. Sem dúvida, deve-se perscrutar se não existem no texto elementos linguísticos que provoquem nos ouvintes, também sob outras considerações contextuais, um determinado efeito. Tal compreensão da pragmática se interessa, sobretudo, pelo autor e por sua competência comunicativa ${ }^{186}$.

\section{c. A força persuasiva da pragmática: os atos linguísticos}

A abordagem comunicativa pretende analisar a força persuasiva de um texto, particularmente de um discurso, por meio de uma análise que vise reconstruir a estratégia que o texto apresenta para atingir sua finalidade. Para o aprofundamento do aspecto estratégico e funcional do uso da linguagem e,

\footnotetext{
${ }^{183}$ Cf. Id., Ibid.

${ }^{184}$ Cf. Ibid., p. 97.

${ }^{185}$ Cf. OBARA, E., Le strategie di Dio, p. 31.

${ }^{186}$ DILMANN, R., Consideraciones en torno a la pragmática In MORA PAZ, C. et al., Lectura pragmalingüística de la Biblia, pp. 60-63.
} 
portanto, da comunicação, segundo Manfredo Oliveira ${ }^{187}$, tem contribuído grandemente a teoria pragmática de J. L. Austin para quem o objeto da pragmática são "os atos linguísticos”. Consoante essa teoria, um ato de fala qualquer, mesmo o mais simples, é uma realidade complexa, contém muitas dimensões, e levanta a pergunta sobre o que se pode fazer com uma expressão linguística, ou seja, que é um ato de fala ${ }^{188}$. Para Armengaud ${ }^{189}$ a pragmática estuda os atos de fala e os contextos nos quais eles se realizam. Por conseguinte, a pragmática é o setor da ciência da comunicação que se concentra sobre os signos linguísticos do agir e estuda, portanto, "a ação" posta mediante a linguagem ${ }^{190}$.

O conceito de ato linguístico como ação completa do locutor no curso da enunciação e o exercício de sua função possibilita captar a ação linguística em sua totalidade e conduz a uma conclusão importante: em um determinado contexto, a comunicação é sujeita a variações de graus, que não dependem unicamente da atitude do emitente, mas da força persuasiva dos atos linguísticos emitidos. Isto, segundo M. Grilli,

Significa reconhecer que uma determinada comunicação verbal tem não só uma função descritiva do objeto em questão (nível locutório), mas igualmente - por exemplo - uma função conativa ou imperativa (nível ilocutório) ${ }^{191}$.

A teoria dos atos linguísticos de J. L. Austin ${ }^{192}$ parte da distinção entre ato locutório, ilocutório e perlocutório.

$\mathrm{O}$ ato locutório corresponde à proferição de um enunciado e compreende os elementos puramente linguísticos, ou seja, os gramaticais e lexicais. É o sentido do que é dito. A análise do ato locutório conduz à recuperação do significado de um enunciado ${ }^{193}$.

O ato ilocutório é a ação que o locutor exercita em relação ao locutário no momento da proferição do enunciado, isto é, como o locutor age sobre ele ao pronunciar algo. A forma expressiva mais evidente do aspecto ilocutório são os verbos performativos que podem caracterizar um ato linguístico como

\footnotetext{
${ }^{187}$ Cf. OLIVEIRA, M. A., Reviravolta linguístico-pragmática na filosofia contemporânea, p. 157.

${ }^{188}$ Cf. Id., Ibid.

${ }^{189}$ Cf. ARMENGAUD, F., A pragmática, p. 61.

190 Cf. GRILLI, M. Comunicação e pragmática. Disponível em: http://www. evangeliumetcultura.org/IT/Comunicazione\%20e\%2Pragmática. php. Acessado em 14 de maio de 2012.

${ }^{191}$ Cf. Id., Ibid.

${ }^{192}$ Cf. OLIVEIRA, M. A., op.cit., p. 157.

${ }^{193}$ OBARA, E., Le strategie di Dio, p. 32 et seq.
} 
asseveração, ordem, pedido, augúrio, promessa etc., verbos que não esgotam, todavia, o valor ilocutório do enunciado determinado, em última análise pelo contexto $^{194}$.

O ato perlocutório, que dificilmente encontra expressão sobre o plano linguístico, representa o efeito que a ação do emitente provoca sobre o ouvinte ou outras pessoas $^{195}$.

A análise dos atos locutórios é fundamental não só na abordagem comunicativa, mas em toda leitura de textos, pois fornece o nível fundamental de entendimento de um texto. Mas não é suficiente.

Porquanto toca ao ato locutório se tratará agora de conseguir encontrar o significado complexo, baseando-se sobre os aspectos puramente linguísticos quais sejam: a morfologia, a sintaxe, a semântica. $O$ valor ilocutótrio do ato linguístico se identificará analisando o uso dos tempos e dos modos verbais, dos advérbios, dos gêneros, etc., segundo o contexto. Enfim, a análise das sucessivas fases da troca comunicativa pode resultar útil por deduzir que efeitos perlocutorios obtêm do emitente da mensagem ${ }^{196}$.

$\mathrm{Na}$ abordagem comunicativa, por isso, ganha grande destaque o exame dos atos ilocutórios. Os atos ilocutórios são classificados em cinco categorias ${ }^{197}$ :

1. Atos representativos ou assertivos - o falante é levado, em graus diversos, a sustentar a verdade de uma proposição, por exemplo, asseverar, crer, concluir, negar, referir.

2. Atos diretivos - o falante expressa o desejo que o ouvinte faça ou não alguma coisa, por exemplo: aconselhar, desafiar, provocar, ordenar, insistir, pedir.

3. Atos comissivos - quando o locutor se empenha, em graus diversos, em algo futuro, por exemplo: promete, jura, compromete-se a comportar-se de certo modo.

4. Atos expressivos - o falante demonstra sentimentos, isto é, exprime uma certa atitude psicológica em referência a um determinado estado das coisas, por

\footnotetext{
${ }^{194}$ Segundo Armengaud, o ato ilocutório consiste em executar ou fazer algo dizendo algo (ordena, pede, deseja, promete). Pode ser ulteriormente classificado isolando cinco diversos subtipos segundo a modalidade de apropriação (adaptação) que se estabelece entre a linguagem e o mundo. Através de um enunciado pode-se, de fato, adaptar a linguagem à realidade, ao mundo; ou então procurar modificar a realidade e, portanto, fazer com que o mundo se adapte à linguagem. Mais precisamente os critérios de classificação adotados por Searle são três: A mencionada direção à adaptação (direção de entrosamento), a intenção, escopo ou razão de ser (propósito, objetivo) e o estado psicológico expresso. Cf. ARMENGAUD, F., op. cit., p. 99.

${ }^{195}$ Segundo Armengaud, os atos perlocutórios correspondem aos "efeitos produzidos por nossas sentenças em nossos alocutários; Entendemos por isso os efeitos diversos da simples compreensão dessas mesmas sentenças. Depende da compreensão de todo o contexto onde tal pronuncimento se localiza”. Cf. Ibid., p. 100.

${ }^{196}$ OBARA, E., op. cit., p. 34 et seq.

${ }^{197}$ Cf. ARMENGAUD, F., A pragmática, p. 111 et seq.
} 
exemplo, sugere, desculpa, lamenta, deplora, congratula-se, agradece, alegra-se, dar boas vindas, rejeita algo.

5. Atos declarativos - quando o falante pronuncia algo que altera o estado de um objeto ou implica uma mudança de situação pelo fato de proferir um enunciado, por exemplo: demite alguém, batiza, absolve, salva, condena, declara guerra.

Naturalmente, vários destes subtipos vêm unidos num mesmo pronunciamento. Não obstante o esforço de atribuir aos diversos atos ilocutórios características particulares e distintas, o enunciado assume habitualmente mais de uma direção da ação, que vem examinada segundo o contexto do processo comunicativo em curso. O texto escrito exige uma análise cuidadosa para se poder de algum modo compreender sua força comunicativa. Isto é feito através da atenção aos elementos gramaticais e aos procedimentos usados ${ }^{198}$.

\section{d. Características do processo comunicativo escrito}

Fala e escrita constituem duas modalidades de uso da língua. Embora se utilizem, evidentemente, do mesmo sistema linguístico, elas possuem características próprias. Essa descrição põe em evidência que escrita e fala não apenas devem ser consideradas duas variedades funcionais de uma única linguagem, como também não devem ser vistas na relação dicotômica de dois polos opostos. As diferenças entre fala e escrita, segundo I. Koch se dão dentro do continuum tipológico das práticas sociais ${ }^{199}$.

Sobre a comunicação escrita diz Alonso Schökel

Aquele que escreve quer falar e dizer, ou seja, quer comunicar e em sua atividade literária começa a criar utilizando o que recebeu de sua comunidade, pois emprega com frequência materiais literários preexistentes e, quando é escutado, o povo o reconhece como o seu intérprete. (...) Toda sua razão de falar ou escrever é o seu povo, a sua comunidade ${ }^{200}$.

Um confronto entre o sistema oral e escrito permite melhor compreender o processo de comunicação entre autor de um texto escrito e leitor. Massimo

\footnotetext{
${ }^{198}$ Cf. OBARA, E. M., op. cit., p. 22.

${ }^{199}$ Cf. KOCH, I. V., O texto e a construção de sentidos, p. 77.

${ }^{200}$ Cf. SCHÖKEL, A., A Palavra inspirada, p. 152 et seq.
} 
Grilli $^{201}$ apresenta três critérios para este confronto - o meio, o contexto e a função.

1. O critério do meio: O texto oral é um texto vivo, fragmentado, com enunciado mais breve e sujeito a contínuos ajustamentos de formulações, explicitações, repetições etc. O discurso oral, sob este aspecto, se apresenta como um evento efêmero que, todavia, é causado por uma interação direta, permite esclarecimento de eventuais incompreensões da mensagem. $\mathrm{O}$ texto falado possui maior complexidade sintática. O texto escrito, ao invés, é estratificado, permanente, conciso, e ao mesmo tempo dotado de uma maior complexidade lexical.

2. O critério do contexto: o problema da proximidade/distância. Um texto oral apresenta características contingentes, que o ligam a um interlocutor preciso (mesmo grupo) e a um preciso contexto espaço-temporal. O texto escrito, ao contrário do oral, pode prever leitores e contextos situacionais diversos do "aqui e agora", e ter que admitir certa "distância comunicativa" de vários tipos: social, cultural etc. $\mathrm{Na}$ análise do discurso escrito se assiste a uma mais ou menos pronunciada solução de continuidade; falta a interação direta, sendo possível usufruir de uma compensação por meio de incessantes releituras, movimentos transversais, para frente e para trás no interior do texto, reelaborações de vários gêneros que possam facilitar a compreensão. Esse procedimento, por um lado, permite encontrar os elementos de pertença e continuidade cultural e literária, juntos àqueles de descontinuidade e originalidade da outra. $\mathrm{O}$ contexto espaçotemporal da troca dialógica, em parte, é o mesmo para os dois, e é provável que seja compartilhado, em certa medida, também a bagagem do conhecimento e as práticas sociais (costumes). É um contexto de informações e de crenças partilhadas, um contexto traduzido em termos de mundos possíveis ${ }^{202}$. Compreender o código/sistema dos sinais que transmitem o significado constituise a chave da comunicação ${ }^{203}$. Em alguns casos pode-se tentar uma reconstrução

201 Cf. GRILLI, M. artigo Pragmatica $e$ analisi del texto. Disponível em: http://www.evangeliumetcultura.org/IT/Pragmatica\%20e\%20analisi\%20del\%2Otesto.php Aces sado em 14 de maio de 2012.

${ }^{202}$ Cf. ARMENGAUD, F., A pragmática, p. 65.

203 "O conjunto dos processos que constitui a transmissão do código, da codificação à descodificação constitui o processo da comunicação. Os sinais que formam um código são em número restrito; o próprio número desses sinais é, na maioria das vezes, convencional e só varia de acordo com os usuários do código. O código é, pois, um sistema convencional explícito. O código específico do texto é definido como o sistema de signos por meio dos quais a mensagem vem 
atingindo outra fonte de informação, mas dificilmente tais reconstruções poderão superar os níveis de uma suposição ${ }^{204}$.

3. O critério da função. Quanto à função, um texto oral e um texto escrito possuem proporcionalmente os mesmos objetivos. Textos narrativos ou descritivos ou argumentativos ou regulativos podem perseguir os mesmos escopos, seja em um contexto oral, seja escrito. Destas considerações se conclui que um texto escrito - na qual a história foi consignada em forma expressiva fixa - apresenta maior dificuldade de interpretação que um texto oral. Em uma comunicação verbal de tipo oral, o tom da voz, a expressão da face, os gestos são indícios que ajudam a discernir consideravelmente as funções de um determinado texto; enquanto que em um texto escrito o processo se apresenta mais articulado e certamente mais trabalhoso.

E. Obara ${ }^{205}$ acrescenta que, com a fixação da mensagem em forma escrita, se põe a questão da exteriorização do potencial comunicativo do ato do discurso.

Estas considerações têm um peso particular no campo dos estudos bíblicos onde, para superar a distância, se faz necessário o recurso ao estudo comparado quer seja no interior da obra, quer seja em outras obras da Sagrada Escritura. Não se deve esquecer que os elementos dos sistemas comunicativos interagindo dinamicamente entre eles, se compenetram e se influenciam alternadamente. A análise pede ainda que se entre neste dinamismo descobrindo, no texto particular, a estratégia adotada para a produção de sentido ${ }^{206}$.

\section{4 \\ Conclusão}

O fato de que o texto seja uma unidade em ordem a uma comunicação corresponde, na mente do emitente, a uma determinada intenção comunicativa, que se põe no interior de uma estratégia de comunicação. Ao texto o emitente reconhece seja a função de comunicar uma mensagem seja as características de unidade e completude, próprias de toda mensagem, sejam os requisitos necessários para que uma mensagem seja realmente efetiva e alcance o objetivo

transmitida". Cf. DUBOIS, J. et al., verbete "código", DUBOIS, J. (Org.)., Dicionário de Linguística, São Paulo: Cultrix, 1993, p. 114.

${ }^{204}$ Cf. OBARA, E., Le strategie di Dio, pp. 34-35.

${ }^{205}$ Cf. Ibid., p. 34 et seq.

${ }^{206}$ Cf. Ibid., p. 35. 
previsto $^{207}$. O importante é que haja uma organização interna, seja por coesão sintática, seja por coerência semântica e pragmática. Todo texto, se lido em chave comunicativa, tem muita potencialidade, mas tem necessidade que o leitor colabore na sua atualização. Para verificar essa organização interna faz-se necessário iniciar o procedimento metodológico pela análise dos aspectos formais do texto.

${ }^{207}$ GRILLI, M., Pragmatica e analisi del texto, Disponível em: http://www. evangeliumetcultura.org/IT/Pragmatica\%20e\%20analisi\%20del\%2Otesto.php Aces sado em 14 de maio de 2012. 
O texto de Jo 5,19-47 em seus aspectos formais

\section{1.}

Tradução, crítica textual e delimitação do texto

\subsection{1.}

Tradução do texto de Jo 5,19-47

19a Apekri nato oufo' 'Vhsoul'

Respondeu $^{208}$, pois, Jesus

19b kai. el egen autoi $\bigwedge$

e disse-lhes:

19c anhn anhnn I egw uǹnh'

"amém, amém, digo-vos:

19d an dunatai o’ uiòj poièn afV o Filho, por si mesmo, nada pode èutour ouden

fazer,

19e $₫$ nh, ti bl eph| ton patera senão aquilo que vê o Pai fazendo; poi ountal

19f a]gar ah ekeinoj poi hl

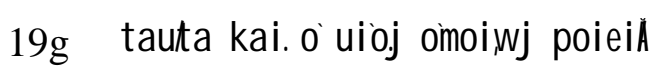

Portanto, tudo que Ele faz, isto também o Filho da mesma forma faz.

$20 \mathrm{a}$

o’gar pathr filej/ton uiòn

Portanto, o Pai ama o Filho

20b kai . panta de knusi n autwy

e lhe mostra tudo

20c a]autroj poi $\dot{\ell} \ell$

o que Ele faz;

20d kai. neizona toutwn dexei autw/ e lhe mostrará obras maiores do que ergal

estas

\footnotetext{
${ }^{208}$ Segundo Rusconi o verbo apokri nonai denota reação verbal a uma interpelação por palavra ou fato. Tem o sentido de defender, justiçar, de responder a uma pergunta, a alguém, a uma acusação, ordem ou prece; ou de tomar a palavra. Cf. RUSCONI, C., Dicionário do grego do Novo Testamento, 2003, p. 67. A opção na tradução por "responder" deveu-se ao fato de que a esta forma verbal segue-se a expressão anhn anhn I @gw ù̀nh Para Joachim Jeremias o "amém" vem sempre como uma resposta, para confirmar ou reforçar uma declaração. Cf. JEREMIAS, J., Abba, Jésus et son Pére, 1972, p. 100. Além disso, o verbo I egw (a LXX traduz a fórmula hebraica rnatow por kai. . ege ) ao contrário do que ocorre na frase do narrador em 5,18 ao responder a acusação proferida, conserva o seu sentido de 'reagir' (cf. Mt 12,25; 26,25). Para Zerwick esta introdução é equivalente à fórmula hebraica de introduzir uma palavra de Deus: huhyornałurespondeu e disse. Cf. ZERWICK, M., Biblical Greek, Roma: Pontificio Istituto Biblico, 2005, p. 128.
} 
20e i ha uṅi'l' qaunazhte

21a WEper gar o` pathr egéré touj Como o Pai levanta os mortos nekrouj

21b kai. zuppoi e $\ell$

21c oufwj kai.o ui òj zuppoiè)

21d oull qd $\mathrm{e}$

22a aude gar o’ pathr kriné oudenal

22b all a. thn krissin pasan deduken twiuivi

23a i ha pantej ti nowsi ton ui òn

23b kaquj tinowsi ton paterar

$23 \mathrm{c}$ o’nh. ti nowh ton ui òn

23d anti nay/ton patera

$23 \mathrm{e}$ ton penyanta autron

24a Anhnn anhnn I egw uninht

24b ofi o'ton I ogon nou akoumn

$24 \mathrm{c}$ kai.pisteumn

24d tw/penyanti, ne

$24 \mathrm{e}$ ece zwhn ai wrion

24f kai .ejk krissin ouk ercetai (

$24 \mathrm{~g}$ all a. netabęhken ${ }^{<\perp}$ ek toul mas passou da morte à vida. canatou ejj thn zwhn̊ e faz viver,

assim também o Filho faz viver

aqueles que quer.

Pois o Pai a ninguém julga,

mas deu ao Filho todo julgamento,

a fim de que todos honrem o Filho,

assim como honram o Pai.

Quem não honra o Filho

não honra o Pai

que o enviou ${ }^{209}$.

Amém, amém, digo-vos:

quem escuta a minha palavra ${ }^{210}$

e crê

naquele que me enviou ${ }^{211}$

tem vida eterna,

e não vem a julgamento,

\footnotetext{
${ }^{209}$ Neste versículo o uso do verbo penpw sugere a missão, a obra a ser realizada pelo Filho (cf. 24d). Quando o autor usa o verbo apostel I w insiste sobre o fato de que ele estava lá, sobre o envio-vinda do Filho. No texto de 5,19-47 o ato de enviar aparece alternado em duas formas verbais: com o verbo penpw aparecendo nos versículos 23e, 24d, 30e, 37a, (sempre no particípio aoristo - ação concluída, definitiva - 4 vezes) e, na forma verbal aposte I w nos versículos 33a, 36f, 38b (só no indicativo -3 vezes). Mas qualquer que sejam as nuances significativas, o emprego por João dos dois verbos, não quer senão ilustrar e confirmar suas perspectivas teologicas da missão. Mais detalhes nos itens que tratam da Coesão Vocabular (4.2.1) e no da Semântica dos motivos (5.2). Cf. JONGE, M., Les verbes apostel I w e penpw dans le vocabulaire théologique de saint Jean. In Id. L'Évangile de Jean sources, rédaction, théologie, 1977, pp. 385-388.

${ }^{210}$ O léxico "Palavra" vem expresso, no texto, por meio de dois termos: I ogoj (v. 24b, 38a) e rhna (47b). O evangelista alterna o uso de I ogoj como "palavra" com rhna. Aqui o termo I ogon está traduzido por "palavra" como em 4,39. 41. 50; 8,31. 43. 51. 52; 12,22. 24. 47; 15,20 (2 vezes); 17,14. 20. Porém em 5,47 o termo para designar palavra é rhna como em 3,$34 ; 12,48 ; 14,10 ; 15,7$. A LXX traduz por I ogoj 90 por cento das vezes a palavra hebraica rbD Os outros 10 por cento ela traduz por rhna. Cf. Verbete I ogoj In FREEDMAN, D. N.; TOBIN, T. H., The Anchor Bible Dictionar, New York: Bantam Doubleday Dell Publishing Group, 1992, p. 349.

${ }^{211}$ É significativo que neste texto esse léxico só apareça em formas verbais e nunca como substantivo. Cf. SCHNACKENBURG, R., El Evangelio según San Juan, v. 2, Salamanca: Herder, 1980, p. 146.
} 
25a anhn anhn I egw ù̀mh

25b ofi ercetai wra

$25 \mathrm{c}$ kai.nuh etir

25d ofe oi nekroi. akousousin thi f unhil tou/ui ò/toulgeoul

25e kai. d $^{<1 s}$ akousanté

25f zhsousin

26a w\$sper gar o’ pathr ecé zwhn ea èutw

26b oufwj kai . tw/ ui ì/ ed/ken zwhn ecei n ea eàutwÂ

27a kai. exousian eolkken autw/ krissin poi eith

27b ofi uiòj anqrupou esti w

28a nh. caunazete toukd

28b ofi ${ }^{<14}$ ercetai wra

$28 \mathrm{c}$

$28 \mathrm{~d}$

$29 \mathrm{a}$

$29 b$

29c a ‘ de ta. faula praxanté

30a oun dunanai egw. poi ein
$30 \mathrm{~b}$

ea h|pantej à ‘a toij' mmnei oij

akousousin thi' f unhl autrou

kai . expor eusontai

ta. agaca. poi hsanté amastasi n zwhill amastasin krisevj $\AA$ exautou/ oudenl

kaqnj akoun krinml
Amém, amém, digo-vos:

vem a hora

e é agora

em que os mortos ouvirão a voz do Filho de Deus,

e os que ouvirem

viverão.

Assim como o Pai tem vida em si mesmo,

Assim também deu ao Filho ter vida em si mesmo,

e lhe deu autoridade de fazer julgamento,

porque é Filho do Homem.

Não vos admireis com isto:

vem a hora

na qual todos os que estão nos sepulcros

ouvirão a sua voz

e sairão:

eij os que tiverem feito o bem, para uma ressurreição de vida;

ej $\mathrm{j}$ os que tiverem praticado o mal, para uma ressurreição de julgamento.

$\mathrm{ap} \mathrm{V} \mathrm{Eu}$, por mim mesmo, nada posso fazer:

conforme ouço, julgo

\footnotetext{
${ }^{212}$ A tradução desse verbo está no tempo perfeito, por se encontrar ligado ao sentido da preposição dk conforme explicado no item 4.2.2, referente aos aspectos sintáticos do texto, ao analisar o v. 24g.

${ }^{213}$ Boismard seguindo os textos do Papyro 66, $S$ l Tertuliano, faz suprimir, no v. 25e, o artigo diante do particípio, traduzindo: e ouvindo, viverão. Cf. BOISMARD, M.-E.; LAMOUILLE, A. L'Évangile de Jean, v. 3, Paris: Éditions du Cerf, 1977, p. 165.

${ }^{214}$ V. 28b: A ambiguidade da conexão đđi que pode ser causal ou declarativa. O problema da tradução de ofi ercetai wła pode referir-se ao que precede (uso anafórico) ou ao que segue (uso catafórico). Cf. ZERWICK, M., Biblical Greek, Roma, 2005, p. 142. A tradução aqui optou pela uso catafórico da conjunção đđi como um cólon porque os verbos akousousin (v. 28d) e ekpor eusontai (v. 29a) além de estarem no futuro, veem antecedidos do termo "hora".
} 
30c kai.h`krissij h`eah. dikai a extin e meu julgamento é justo,

30d ofi ounzhtw/to. qd hma to. exon porque não procuro minha vontade,

30e all a. to. od hma tou/penyantoj n Mas a vontade do que me enviou.

31a Ean egw. Mar turw/peri. exautak Se eu dou testemunho de mim mesmo,

31b h'narturia nou ouk estin alhohi\o meu testemunho não é verdadeiro $^{215}$;

all loj estin o’ narturwh peri. outro é que testemunha sobre mim,

32a enouk

32b kai.oi

32c ofi alkhohi etin h'marturia

e sei

32d hin narturei/peri. enow

que verdadeiro é o testemunho

33a unei'l' apestal kate proj Vwannhn( que testemunha sobre mim.

33b kai . nemarturhken th/aluhoj al Vós enviastes (emissários) a João,

34a egw. de an para. angrupou thn narturian I anbanw o qual deu testemunho da verdade.

34b all a. tauka I egw testemunho de um homem;

$34 \mathrm{c}$ i ha unieil' swohted mas falo essas coisas

35a dkei hoj hao'l unnoj o' kai onenoj para que vos salveis.

35 b kai . f ai nunx Ele era a lâmpada acesa

$35 \mathrm{c}$ uñel' de hod hsate agal I i achnai e brilhante, proj wran en tw/f wti . autrouA vós, porém, vos alegrastes, por algum tempo, com sua luz.

36a $\mathbb{E g w}$. de ecw thn marturian neizw Eu, porém, tenho um testemunho tou/ Vwannoul maior que o de João:

36b ta. gar erga a] dedkken nøi o’ as obras que o Pai me deu pathr

36c i ha tel ei wsw autral

36d auta. ta. erga a]poi w/

36e marturei/peri. exou

36f ofi o’ pathr ne apestal keri para que as leve a termo; estas obras que faço, testemunham sobre mim que o Pai me enviou ${ }^{216}$.

${ }^{215} \mathrm{O}$ adjetivo alkhohi reúne neste texto (vv. $31 \mathrm{~b}$ e $32 \mathrm{c}$ ) dois dos diversos matizes do espectro de significados de alhaei a: "verdadeiro" no sentido de ser crível, acreditado, fiável, veraz, justo, reto. É um termo significativo da teologia Joanina porque Deus no Filho se revela como a Verdade (3,3; $7,28 ; 8,26)$ e aqui aparece junto a narturia. Cf. HÜBNER, H., verbete alhhaia In BALZ, H.; SCHNEIDER, G., DENT, v. 3, Salamanca: Sigueme, 1998, pp. 175-174. 
37a kai. o’ penyaj ne pathr

37b dkeinoj nemarturhken peri. exouA

37c oute funhn autrol pupote Nunca ouvistes a sua voz, akchkoate

37d oute ei ebj autrou/èr akated

38a kai . ton I ogon autroul ouk ecete en e não tendes sua palavra, ùìn nenontal

$38 \mathrm{~b}$

38c toutw/ ùnei' ampi stente

39a evaunat $\epsilon^{<10}$ taj graf aj (

39b ofi uǹil' dokéte en autail' zwhn Porque pensais ter nelas vida eterna; ai wnion eceinl

39c kai . Ekè hai, é si n ai

39d narturabai peri.eacul

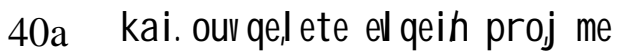

40b i fra zwhn echte

41 Doxan para. anarwpun oun Glória, não recebo dos homens. I anbanny

Aliás, vos conheço: ${ }^{219}$

42b ođi thn agaphn tou/ qeav auk ecete não tendes em vós o amor de Deus. en èutoij $j^{220 \AA}$

43a egw. Ehhl uga en tw/ ononati tol Eu vim em nome de meu Pai, patroj noul

43b kai . oul anbanete, nel

Mas não me recebeis;

$43 c$ can al l oj el ohl en tw/ anonati tW" se um outro viesse em seu próprio idim nome,

\footnotetext{
${ }^{216}$ Aqui no v. 36f o Pai aparece como sujeito do verbo apostel I w porque quer destacar a origem do enviado.

${ }^{217}$ Neste versículo é usado o particípio aoristo òpenyaj neque é a forma mais usada: 17 vezes.

${ }^{218} \mathrm{O}$ verbo está traduzido no indicativo e não no imperativo, pois Jesus não está dizendo aos destinatários coisas que devem fazer, mas reprovando o uso incorreto que eles fazem das Escrituras. Cf. MOLLONEY, F., Il Vangelo di Giovanni, Sacra Pagina, v. 4, Torino: Editrice Elledici, 2007, p. 167.

${ }^{219}$ A tradução aqui optou pelo uso catafórico da conjunção đđ̣i como um cólon por ser a frase explicativa.

${ }^{220} \mathrm{O}$ pronome ėutoij' que pertence à terceira pessoa do plural no dativo foi usado por analogia à forma contrata do mesmo pronome (autoi j'). A forma €̇utoi $j^{\prime}$ usada no texto seria uma contração de uǹnh aukoij. Na verdade os pronomes presentes nessa seção (vv. 40-47) são apenas dois: o de primeira pessoa do singular e o de segunda pessoa do plural.
} 
43d edke hon I hnyesqe

44a pw'j dunasqe uñei'l' pi steubai

44b doxan para. all hl wn I anbanontej ( vós que recebeis glória um dos outros,

44c kai.thn dbxan thn para. tay nonou e não procurais a glória que vem do qeou/ounzhteitei

45a nh. dokètte Deus único?

$45 \mathrm{~b}$ ofi egw. kathgorhsw uǹwh proj que eu vos acusarei diante do Pai: ton pateral

45c estin o'kathgorwh uñwh MmBhi'l É Moisés o vosso acusador,

$45 \mathrm{~d}$ ejj oh uniej' hipi kate

46a eivgar eqi stente Mmsel

46b goistente ah exoi ।

46c peri.gar enou/dke hoj egrayen pois a meu respeito ele escreveu.

47a eivde toij' ekeinou granmasin oun mas se não acreditais em seus pistentel

$47 \mathrm{~b}$ pwi' toij'

exoil rhnasi ${ }^{\ll 1}$ pisteusete $\mathbb{2 2}^{22}$ no qual pusestes vossa esperança. Se, pois, crêsseis em Moisés, creríeis em mim; escritos, como crereis em minhas palavras?

\subsection{2.}

\section{Notas de crítica textual}

O aparato crítico do texto de Jo 5,19-47, segundo o Novum Testamentum Graece $^{223}$ não apresenta variantes dignas de nota, porém pequenas omissões ou substituições que devem ser consideradas:

v. 19a: As seguintes testemunhas $\mathbf{P}^{75} \mathrm{~B} p c$ omitem o` Whsaj'. Jesus é o sujeito do verbo responder (Apkrinato). O nome Jesus é mencionado no texto anterior (5,1-18) 7 vezes, e neste, apenas essa única vez.

v. 19b: As testemunhas $\mathrm{A} D \mathrm{~W} Q \mathrm{Y} f^{13} 33 \mathrm{M}$ trazem a substituição do imperfeito e egen pelo aoristo ou presente histórico èpen Como está muito bem

\footnotetext{
${ }^{221}$ Sobre a tradução do vocábulo rhñ como "palavra" conferir nota 210.

${ }^{222}$ Esta forma pisteusetepertence ao tempo aoristo no conjuntivo, usado com o mesmo valor do futuro indicativo.

${ }^{223}$ NESTLE-ALAND, Novum Testamentum Graece, Editione vicesima septima revisa, Deutsche Bibelgesellschaft, 1993, pp. 261-263.
} 
testemunhado por dois Papyros: $\mathbf{P}^{66}$ e $\mathbf{P}^{75}$ e os códices B e Sinaítico, o imperfeito é suficientemente atestado.

v. 25c: A omissão de kai nuh estin no Sinaítico, nos manuscritos latinos $a$ e $b$ e em Tertuliano. O texto abreviado provavelmente se explica como tentativa do copista de eliminar a diferença com o v. 28.

v. 27a: As testemunhas D Q $f^{1.13} \mathrm{M}$ lat. Syr. trazem a inserção de um kai .(com o sentido de também). Esta inserção põe a função de julgamento de Jesus ao lado do Pai. Sem o kai .a autoridade de exercer o julgamento é somente de Jesus.

v. 32b: a substituição de oi (sujeito egn) por oi Evangelho (cf. 1,$48 ; 2,24 ; 6,6.15 ; 7,29$ etc) e no próprio texto de Jo 5 Jesus é apresentado como aquele que conhece as coisas, que tudo sabe (cf. 5,6).

v. 44c: A mais importante variante é a que traz a omissão da palavra qeou/neste versículo $44 \mathrm{c}$ pelas testemunhas $\mathbf{P}^{66.75} \mathrm{~B} \mathrm{~W}$ a b as $\mathrm{ac}^{2}$ pbo $b o^{p t}$. Embora o peso externo dos manuscritos seja muito forte, a omissão parece ser o resultado de um descuido na transcrição das letras QU (usadas na contração da palavra qeouß que foi acidentalmente omitido de TOUMONOUQU. No entanto a omissão pode também representar a qualidade por excelência de Deus: O Único ${ }^{224}$.

v. 45b: A variante propõe o pronome uǹaj ao invés de uǹowh devido à dupla regência do verbo kathgoren: ou o acusativo (nesse caso com a forma uñaj') ou o genitivo (aqui com a forma uǹowh). Isto acontece de forma análoga com o verbo akoum que apresenta também essas mesmas regências.

v. 47b: Esta forma verbal pisteuseteaparece na variante pisteushte esta última pertence ao tempo aoristo no conjuntivo, usado com o mesmo valor do futuro indicativo.

Este estudo não adotará nenhuma destas variantes. Seguirá o texto conforme se encontra em Nestle - Aland.

\footnotetext{
${ }^{224}$ A insistência sobre a unicidade de Deus (tar nonou qeoü põe o acento sobre o fato de que o Senhor do sábado é o único verdadeiro Deus de Israel. Cf. VARGHESE, J., The imagery of love in the Gospel of John, Roma: Pontificio Istituto Biblico, AnBib, n. 177, 2009, p. 312.
} 


\subsection{3. \\ Delimitação do discurso de Jo 5,19-47}

O capítulo 5,1-47 apresenta dificuldades em precisar-lhe as subdividisões ${ }^{225}$ e até mesmo quanto à sua conclusão ${ }^{226}$. Também para a delimitação anterior do texto de Jo 5,19-47, há diversas propostas ${ }^{227}$ : a problemática central está na divisão entre as duas seções que compõem o capítulo (5,1-18 e 19-47) ${ }^{228}$. O texto que vem imediatamente anterior a 5,19-47 está caracterizado, neste trabalho, como um texto narrativo $(5,1-18)^{229}$. O texto de 5,19-47 apresenta elementos literários externos e internos que oferecem fortes argumentos para considerá-lo uma perícope com seu início no v. 19, apesar de não estar claro o limite literário posterior do texto precedente de 5,1-18. Na delimitação deste discurso consideram-se os seguintes elementos:

a) Dados formais comumente reconhecidos:

- O fato de os vv. 1-18 e os vv. 19-47, serem explicitamente caracterizados por seus gêneros literários é um forte indício de que são unidades literárias distintas.

- O problema da delimitação entre as duas unidades literárias não é simples: o final dialogado do texto narrativo (v. 18) parece se estender aos vv. 19ss; porém o diálogo articulado anteriormente chega a seu termo natural por uma espécie de sumário. Este pode ser considerado, em si mesmo, uma breve perícope (vv. 1618), no qual o autor interrompe a narrativa para apresentar, de modo resumido,

\footnotetext{
${ }^{225}$ Léon-Dufour apresenta em um quadro as subdivisões do capítulo 5 propostas desde Wescott até Haenchen de Menken. As divergências recaem principalmente sobre a divisão entre os vv. 9 e 10, 15 e 16, 38-39, 40 e 41. Cf. LÉON-DUFOUR, X., Leitura do Evangelho segundo João, v. 2, São Paulo: Loyola, 1998, p. 17.

${ }^{226}$ Como foi exposto (cf. 2.3.1) há, entre alguns estudiosos joaninos, quem defenda sua incompletude e até aponte o texto de Jo 7,15-25 para sua conclusão. Cf. SCHNACKENBURG, R., El Evangelio según San Juan, pp. 126-194; CABA, J., Cristo, Pan de Vida, Madrid: BAC, 1993, p. 36; ZUMSTEIN, J., O Evangelho de João In MARGUERAT, D. (Org.)., Novo Testamento, São Paulo: Loyola, 2009, pp. 437-468; VIDAL, S., Los escritos Originales de la Comunidad del Discípulo Amigo de Jesus, Salamanca: Sigueme, 1997, p. 498; LINDARS, B., The Gospel of John, NCBC, London: Marshall, Morgan \& Scott, 1981, pp. 218-233.

${ }^{227}$ Cf. nesse trabalho o Cap. 2.3, p. 23.

${ }^{228}$ Cf. nesse trabalho o Cap. 2.4.1, p. 30.

${ }^{229}$ Segundo Soares, a noção de gênero literário inclui um conjunto de expectativas e de seleção de elementos da realidade: "É impossível estabelecer classificação lógica ou fechada dos gêneros, porque sua dimensão sempre é histórica. [...] Além dos traços de linguagem, era necessário que se levassem em conta as expectativas do receptor, bem como a obra literária capta a realidade". Cf. SOARES, A., Gêneros literários, São Paulo: Ática, 2007, p. 17. Sobre esta questão Proença acrescenta: "A teoria moderna dos gêneros literários, do linguista Roman Jakobson, se vale de critério aberto, admitindo os gêneros como realidades dinâmicas que possibilitam mudanças, variações e imbricações". Cf. PROENÇA, D. F., A linguagem literária, São Paulo: Ática, 2007, p. 73.
} 
aquilo que acabou de expor ou para, ao término de sua argumentação, introduzir ou antecipar o assunto de que tratará a seguir e que tem um caráter claramente conclusivo. Portanto, os vv. 16-18 teriam a função de um sumário ${ }^{230}$. A colocação dos vv. 16-18 entre os dois textos redimensiona o que foi narrado e o que será dito, iniciando-se, assim, no v. 19 um novo texto discursivo ${ }^{231}$.

- Quanto à hipótese de que a delimitação anterior do segundo texto (vv. 19-47) seja a partir do v. 14, defendida por alguns exegetas ${ }^{232}$, considera-se que os versículos da seção 14-18 teriam a função de passagens-ponte ${ }^{233}$, além de ser ao mesmo tempo limite para o texto anterior e contexto para dar início a um novo texto anunciado e preparado por estes versículos. Os termos utilizados neste anúncio não se confundem com os do discurso ${ }^{234}$ : a forma verbal evgazonai (v. 17) não aparece no discurso que emprega o termo poi ėh, igualmente a dupla “o' pathr nou kai. egW', (meu Pai e eu) não se encontra no discurso e nem, também,

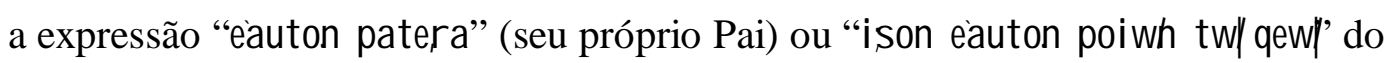
v. 18 (fazendo-se igual a Deus). Assim o discurso, convenientemente introduzido, se distingue notadamente do texto que o precede. Em suma, também, segundo esta hipótese, o v. 18 é limite posterior para a unidade narrativa ${ }^{235}$.

- Em relação ao texto imediatamente posterior a Jo 5,19-47 não há dúvidas quanto à sua delimitação. O início deste novo texto (Jo 6,1ss) é formalmente bastante sinalizado, não apresentando nenhuma dificuldade: nem temática, nem literária, nem semântica. Há presença de novo gênero literário; de novos elementos que se podem constatar, desde o início da perícope, pela riqueza de detalhes: mudanças de situação e de local, de destinatários, personagens, de assunto; além de o vocabulário se distanciar muito da fala anterior (cf. 6, 6. 14).

\footnotetext{
${ }^{230}$ Cf. DIAS DA SILVA, C. M., et al., Metodologia da exegese bíblica, São Paulo: Paulinas, 2000 , p. 73.

${ }^{231}$ Segundo Michele Morgen, a dificuldade em se delimitar um texto joanino provém do processo de charneira, habitual nesses escritos: uma passagem serve, ao mesmo tempo para encerrar uma seção e abrir outra. Cf. MORGEN, M., As Epístolas de João, São Paulo: Paulinas, 1991, p. 31.

${ }_{232}^{23}$ Cf. nesse trabalho o Cap. 2.4.1, p. 30.

${ }^{233}$ As passagens ponte, segundo Mlakuzhyil, são justamente aquelas que servem de "ponte" ou conectam duas unidades sucessivas, concluindo a primeira e introduzindo a segunda; não é uma mera transição. Cf. MLAKUZHYIL, G., The Christocentric Literary Structure of the Fourth Gospel, Roma: Pontificio Istituto Biblico, AnaBib, n. 117, 1987, pp. 104-106.

${ }^{234}$ Cf. VANHOYE, A., La composicion de Jn 5,19-30 In DESCHAMPS, A.; HALLEUX, A., (Ed.), Mélanges Bibliques, en hommage au R. Béda Riguax, Gembloux: Duculot, 1970, p. 260.

${ }^{235}$ Cf. MLAKUZHYIL, G., op. cit., p. 105.
} 
b) Indicações específicas que determinam o texto na qualidade estritamente comunicativa:

1) Uma introdução em dois momentos assinala a presença de uma nova unidade comunicativa: no primeiro momento um narrador introduz, em fala indireta, o futuro locutor (vv. 19a-b); no segundo momento, acontece a introdução do discurso pelo locutor, em fala direta, e com solene autoridade (v. 19c);

2) Um único locutor. Com exceção dos dois versículos introdutórios ao discurso (vv. 19a-b), o conjunto dos vv. 19c-47b não contém nenhum indício de outro locutor;

3) Nova estratégia comunicativa: tom exortativo. A recorrência à fórmula anhnn anhn I egw ù̀mh nos vv. 19a; 24a; 25a caracteriza uma particular finalidade persuasiva;

4) $\mathrm{O}$ locutor dirige-se ao interlocutor durante todo o discurso sempre em $2^{\mathrm{a}}$ pessoa do plural;

5) A focalização de um específico grupo dos referentes. Os ouvintes/leitores são pessoas que conhecem a Lei de Moisés (cf. o v. 47); o verbo Eraunałv (investigar, indagar) refere-se aqui ao estudo minuncioso, próprio dos rabinos (cf. v. 39: evaunate);

6) A temática é própria: a da cristologia filial. A vinculação entre o Pai e o Filho, de modo explícito, não se descobre antes do v. 19d, que põe em uma luz mais clara as relações de Jesus com seu Pai. A autodesignação de Jesus como "o Filho" se explica a partir de suas relações com o "Pai".

7) A mensagem teológica demonstra mudança no nível da comunicação: Jesus eleva muito alto o olhar dos ouvintes. A perspectiva da qual Jesus fala é totalmente diversa do texto anterior: aqui quem fala é "o Filho".

Quanto à problemática da incompletude do texto, cujo final seria 7,15-25 levantada no capítulo $2(2.3 .1)^{236}$, ela tem que ser considerada em sua dimensão comunicativa. Um texto literário se caracterizaria por um começo, um meio e um fim. Seria, portanto, marcado por um fecho. A questão, porém, é outra, longe de ser pacífica. Um texto pode não se fechar, ficando aberta à imaginação do leitor ou ouvinte a solução ou as soluções para as tensões ou os conflitos nele

\footnotetext{
${ }^{236} \mathrm{O}$ argumento de que o texto se estende ao capítulo 7 , versículos $15-25$, por fazer referências à situação relatada em 5,18 é insuficiente, uma vez que o eco desta problemática se encontra também em outros textos (cf. 8,31-33; 11,53).
} 
apresentados. Em termos estruturais, a partir do entendimento de que um texto literário se constitui de relações recíprocas entre o autor e o leitor pode haver abertura ou fechamento. Nos textos em que a ação da última sequência admite o prosseguimento para além do discurso acabado, ele permanece aberto ${ }^{237}$, donde se conclui que a problemática da completude do texto está relacionada com a coerência temática (cf. 4.3).

Portanto, o texto de Jo 5,19-47 constitui uma perícope delimitada, tanto literária quanto tematicamente, com um elevado grau de coesão interna, seja do ponto de vista lexical, seja do ponto de vista sintático. O exame aprofundado destes dois aspectos permitirá detectar a trajetória mais adequada para a análise de sua coesão e de sua coerência, pois o conhecimento da tessitura do texto é condição para que seja compreendido em profundidade.

\section{2.}

\section{A Coesão do texto}

A coesão se efetuará ao analisar o modo como os componentes da superfície do discurso de 5,19-47 se encontram conectados entre si, numa sequência linear, por meio de dependências de ordem lexical e gramatical.

\subsection{1.}

\section{A coesão do vocabulário de Jo 5,19-47}

O léxico do texto de Jo 5,19-47 apresenta um número muito reduzido de vocábulos que se repetem com uma frequência incomum ${ }^{238}$, criando uma forte coesão interna que, por sua vez, constrói a textualidade a qual exprime os motivos formadores do tema do texto.

- O vocábulo pathr se repete nos vv. 19e; 20a; 21a; 22a; 23b; 23d; 26a; 36b; 36f; 37a; 43a; 45b e aparece, neste texto, sempre determinado na forma de um sintagma nominal "o’ pathr". Além dessas repetições este vocábulo se acha substituído: a) pelas formas pronominais ekei hoj (vv. 19f; 37b; 38b), autroj (vv.

${ }^{237}$ Cf. PROENÇA, D. F., A linguagem literária, p. 78 et seq.

${ }^{238}$ Além dos substantivos, os adjetivos também são escassos: nđi zW, neizona (maior, maiores v. 36a, 20d), nekrouj (mortos v. 21a), ai uni on (eterna v. 24e), nonou (único v. 44c), aluhohi (verdadeiro 23c, 31b). 
20c; 37c; 37d, 37e), no v. 32a o pronome-adjetivo indefinido nominativo al I oj se refere ao que presta o testemunho verdadeiro do v. 32c; b) pelo particípio aoristo ativo penyanti (dativo) e tor/penyantoj (genitivo) nos versículos vv. 24d e 30e; c) é o sujeito oculto: do verbo déknusin nos vv. 20b e 20c; sujeito de zuppoi è / no v. 21 b( o sujeito de dedhken no v. 22 b, e no v. 27 a de eqhken

- O vocábulo o’ ui òj aparece também, neste texto, oito vezes, sempre determinado na forma de um sintagma nominal ò uiòj nos vv.19g; 20a; 21c; 22b; $23 \mathrm{a} ; 23 \mathrm{c} ; 25 \mathrm{c} ; 26 \mathrm{~d}$; afora as duas vezes nas quais ele vem determinado nos vv.

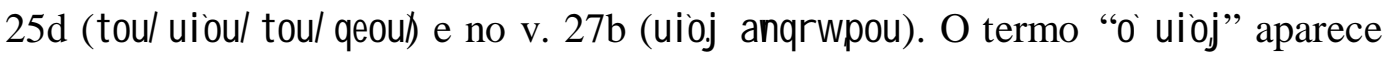
ainda substituído pelo pronome autrod nos versículos 20b, 20d, 27a, 28d e pelo pronome aqui em João. Esta repetição do sintagama nominal o ui òj indica tratar-se de uma das reivindicações fundamentais que o autor atribui a Jesus ${ }^{239}$.

- Outro vocábulo que é muito recorrente no texto (onze vezes) e vem sempre relacionado ao par "Pai-Filho" é o verbo poi êN. O sujeito de poi ené com especial frequência o Pai ou o Filho e está sempre na voz ativa. Referindo-se ao fazer do Pai e/ou ao do Filho, isto é, à sua obra, esse mesmo verbo aparece nos versículos 19d; 19e; 19f, 19g, 20c; 21b; 21c; 27a; 29b; 30a; 36d, apresentando-se nos vv. $21 \mathrm{~b}$ e $21 \mathrm{c}$ em sua forma composta zuppoiej/(fazer viver, dar a vida) ${ }^{240}$. A presença da expressão krișin poieih (v. 27a) surpreende, uma vez que João conhecia o verbo krinw(cf. vv. 22a; 30b). O verbo poi eN está em estreita ligação com outros temas como ZWh, (vida vv. 21b e 21c), penpw (envio 23e), krisij (julgamento v. 27a, 30a), pisteum(crer v. 44a).

- Em relação com o verbo poien no texto, se encontram as formas verbais dunanai que condiciona o ato do "fazer" do Filho à autoridade do Pai (vv. 27a; 30a) e o limita ao enviado (vv. 19d e 19e): o poder de fazer é só para quem vê (b epé) o Pai fazer e Jesus tem visto a atividade do Pai (cf. 8,38), porque o Pai ama (fil é/ v. 20a) o Filho (5,20; cf. 3,35; 10,17; 15,9; 17,23-24), e lhe mostra

\footnotetext{
${ }^{239}$ No aspecto formal o Evangelho de João é o que mais põe em relevo a relação Pai-Filho e, sobretudo, isto ocorre neste texto $(5,19-47)$.

${ }^{240}$ No texto aparece 11 vezes incluindo a forma composta zuppoi $\dot{e} /$ No Evangelho aparece 110 vezes.
} 
(deiknusi n) $)^{241}$ o que faz $(5,20)$. Também associado ao mesmo sentido está o verbo dar (d dwni, vv. 22b; 26b; 27a; 36b).

- Os termos zwh, e krișij, objetos do "fazer" do Pai, aparecem formando uma nova dupla que se opõem. O léxico ZWh,(vida) se repete nos vv. 24e, 24g, 26a, 26b, 29b, 40b, e no v. 39b na expressão zwhn ai wni on (vida eterna). Além do substantivo, o verbo zaw aparece em sua forma verbal zhsousin (v. 25f) e seu composto zuppoi $\Theta$ /(vv. 21b, 21c).

- No outro polo do paralelo antitético estão o termo krișij (vv. 22b, 24f, 27a, 29c, 30c), e a forma verbal kriné (vv. 22a. 30b) que se repetem aos pares: "vivificar-julgar e vida-julgamento": cf. vv. 21 b e 21c com 22a e 22b; 24c e 24f; e $26 a-26 b$ e 27 a ; 29b e 29c. Este contraste "vida-julgamento" interfere com um outro par: nekraij (os mortos) e zuppoi ej/(vivificados)( nos vv. 21a e v. 21b; no v. 24g: qanatoj - zwh,(morte-vida) e no v. 25d nekroi, (os mortos) e zhsousin do v. $25 \mathrm{f}$ (viverão) e no v. 28c (os que jazem nos sepulcros) e no v. $29 \mathrm{~b}$ amastasin ZWhi' (ressurreição de vida). Apesar de aparecer somente uma vez, a forma verbal egèrè (v. 21a) também é um termo chave neste contexto.

- Em correlação com o tema do julgamento está o verbo ti nay $w^{242}$ que aparece 6 vezes no texto (ocorrendo quatro vezes consecutivas: vv. 23a, 23b, 23c, 23d) com o sentido de que se reconheça a autoridade especificamente divina do Filho conferida pelo Pai ao delegar-lhe a atividade de julgar: "oude gar o' pathr kri né oudena( all a. thn krissin pasan dedwken tw/ ui wi" $(5,22)$.

- O par "pathr - ui òj" se encontra relacionado nos v. 24 e 30 com outro par que lhe equivalem: "nou - tw/ penyanti, në'. O verbo penpw no sentido de enviar aparece, no texto nos vv. 23e, 24d, 30e, 37a, e tem a função de indicar que a iniciativa da missão procede do Pai e permanece presente na obra do Filho ${ }^{243}$, mediante a fórmula o` penyaj ne (em $24 \mathrm{~d}, 30 \mathrm{e}, 37 \mathrm{a})$, expressando a realidade

\footnotetext{
${ }^{241} \mathrm{O}$ uso do indicativo presente deknusin (v. 20b) contrastando com o futuro dèxej (v. 20d), é provavelmente deliberado, indicando uma continuidade no relacionamento $(10,15 ; 8,55)$ e não simplesmente uma visão ocasional. Cf. KEENER, C., The Gospel of John, a Commentary, v. 2, Massachussetts: Hendrickson Publishers, 2005, p. 648.

${ }^{242}$ Cf. HÜBNER, H., verbete ti naw In BALZ, H.; SCHNEIDER, G., DENT, p. 1751.

${ }^{243} \mathrm{O}$ verbo penpw (enviar - 4 vezes) só no particípio aoristo. Cf. RITT, H., Verbete penpw In BALZ, H.; SCHNEIDER, G., DENT, p. 872 et seq.
} 
histórica do envio do Filho pelo Pai. Quando se fala da finalidade que persegue o envio de Jesus, em se tratando de sua função como revelador e redentor, o autor prefere o termo apostel I ein(vv. 33a, 36f, 38b) ${ }^{244}$.

- Estreitamente ligado ao envio está o termo đgon (obra) que neste texto só aparece no plural ๔ga (vv. 20d, 36b; 36d) e sempre em relação direta com o Pai: é o Pai quem mostra "as obras" ao Filho (v. 20d), quem lhe dá a tarefa de concluí-las (36c) e, por isso, ao "fazê-las", elas testemunham sobre a "identidade" do Filho manifestando, assim, sua glória.

- Referindo-se à manifestação das obras aparece o termo doxa. No texto de Jo 5,19-47 o termo doxa (Glória) aparece no contexto em que Jesus fala do testemunho das Escrituras (vv. 41; 44b; 44c), estando seu sentido carregado da ambiguidade da linguagem joanina (cf. v. 44b). Nos vv. 41 e 44b, dbxa porta o sentido do grego clássico e helenista, que significa normalmente "opinião", "reputação", valor, honra ${ }^{245}$; no v. 44c no sentido bíblico judaico de "Glória de Deus": esplendor do poder divino, entendendo-se como a revelação do poder de Deus, ou como uma intervenção na história, feita pelo poder de Deus e por iniciativa dele ${ }^{246}$. Pertencente ao contexto de glória, no Evangelho está associado o termo wFa (hora) que neste texto tem implicações com a chegada da "hora messiânica" (v. 25b) e com o cumprimento do julgamento (v. 28b).

- A ideia do "testemunho" aparece por meio do substantivo narturia e do verbo narturen (testemunhar) ${ }^{247}$ que têm no texto uma forte presença, especialmente entre os vv. 31-39. Isto é evidente nas frequentes recorrências: narturia aparece nos vv. 31b, 32c, 34a, 36a, e o verbo narturen nos vv. 31a, 32a, 33b, 36e, 37b,

\footnotetext{
${ }^{244}$ Cf. No Evangelho aparece ao todo 15 vezes. Conferir especialmente 6,29; 8,42; 10,36; 17,3.

${ }^{245}$ No v. 23 o termo para honra é ti nowis, ti nh,no sentido de prestígio.

${ }^{246}$ Verbete doxa, Dicionário Internacional de Teologia do Novo Testamento, 2000, p. 902.

${ }^{247} \mathrm{O}$ verbo martureN aparece com maior frequência no Ev. de João (33 vezes das 76 no NT afora dez vezes nas cartas dele). Usado em sentido absoluto marture $\mathrm{N}$ significa dar testemunho (1 Jo $5,6 \mathrm{~s}$ ) ou também afirmar solenemente (Jo 12,17; 13,21). Com acusativo de coisa significa atestar, e o mesmo sentido tem com ofi $(4,44)$. Com dativo de pessoa e oti, o verbo narturen significa confirmar/ testificar alguma coisa a alguém (Jo 3,28s) Se se fala de dativo de coisa, então significa "dar testemunho em favor de algo" (unicamente no Evangelho de João, 3 Jo, At 14,3). A construção narturen peri.ti noj que aparece dezenove vezes em João e que fora deste evangelho não se encontra no NT, a não ser na $1 \mathrm{Jo}$, por certo refere-se sempre a Jesus. Em todo o Evangelho a "Fé" joanina está sempre referida a testemunhos. Cf. BEUTLER, J., verbete nartureNIn BALZ, H.; SCHNEIDER, G., DENT, p. 168 et seq.
} 
39d. Também a ideia de cumprimento, que pertence ao mesmo campo semântico, vem expressa pelo verbo qd $\mathbf{w}$ (plenificar, levar a termo - quatro vezes).

- O léxico "Palavra" vem expresso, no texto, por meio de dois termos I ogoj (v. 24b, 38a) e rhha (47b) ${ }^{248}$. No Evangelho de João o termo I ogoj no Prólogo $(1,1)$, afirma a preexistência da Palavra de Deus que assumiu uma realidade histórica na pessoa de Jesus $(1,14)^{249}$. No v. 24b o termo I ogg (o mesmo usado no Prólogo) no texto implica uma revelação, trata não tanto de uma ideia divina, quanto de uma comunicação do Filho: ofi o’ ton I ogon nou akoumn kai . pi steumn tw/ penyanti, ne (v. $24 \mathrm{~b}$ cf. v. $25 \mathrm{~d})^{250}$. Os termos que, neste texto, se referem a "I ogoj" (vv. 24b, 38a) ${ }^{251}$, e rhnasin (v. 47b) ${ }^{252}$ como Palavra, apesar de não serem muito recorrentes, estão respaldados por outros termos e formas verbais que pertencem ao campo semântico da "revelação de Deus por sua Palavra dita no e pelo Filho" a qual permeia todo o discurso de Jo 5,19-47. São eles: o verbo akoum que aparece seis vezes (vv. 24b; 25d; 25e; 28d; 30b; 37c), pi stean (vv. 24c; 38c; 44a; 46a; 46b; 47a; 47b, sete vezes), I anbanw (vv. 41, 43b, 43d, 44b, quatro vezes), I egw (34b), evaunaw (v. 39a), graf w (vv. 46c; 47a); os substantivos: f whh,(v. 25d; 28d; 37c), taj graf aj (v. 39a) ${ }^{253}$.

Concluindo: no vocabulário destacam-se os substantivos pathr e uiòj. A frequente repetição destes termos "pathr - ui òj" permite considerar este par linguístico como a chave para entender o discurso, uma vez que o evangelista preparou sua introdução no v. 18: "Ele chamava Deus seu próprio Pai”. No

\footnotetext{
${ }^{248}$ A LXX traduz por I ogoj 90 por cento das vezes a palavra hebraica rbd"' Os outros 10 por cento ela traduz por ritha. Cf. Verbete I ogoj In FREEDMAN, D. N. (ed.), The Anchor Bible Dictionary, New York: Bantam Doubleday Dell Publishing Group, 1992, p. 349.

${ }^{249}$ Cf. KITTEL, G., verbete I ogoj In Id. FRIEDRICH, G.; KITTEL, G. (Orgs.)., Grande Lessico del Nuovo Testamento, v. III, Brescia: Paideia, 1967, p. 366.

${ }^{250}$ Cf. SCHNACKENBURG, R., El Evangelio según San Juan, pp. 241-242.

${ }^{251}$ A Palavra de que fala o Prólogo de João se caracteriza por ter uma existência pessoal, conservando seu profundo sentido de revelação. Cf. GARCIA-MORENO, A., Temas teológicos del Evangelio de San Juan, I. Madrid: Ediciones RIALP, 2007, p. 144.

${ }^{252} \mathrm{O}$ termo rhnasin (47b) no texto está situado no âmbito da palavra escrita, portanto, das Escrituras.

${ }^{253}$ Constata-se, a predominância das formas verbais relacionadas com o campo semântico de textos de revelação: deiknuni (mostrar v. 20b e 20d), caunazw (admirar v. 20e, 28a), doken (pensar v. 39b v. 45a), kategoren (45b, 45c ), zhteN (procurar, v. 30d e v. 44c), além das quinze formas verbais que só aparecem uma vez e que pertencem ao mesmo contexto. São elas: apokri nonai (v. 19a), d epw (v. 19e), f il en (v. 20a), prassw (v. 29b), sukw (v. 34c), agal I i aw (v. 35c), f ai nw (v. 35b), kai w (v. 35c), ờaw (v. 37d), nenw (v. 38a), (v. 39a), gi nuskkw (v. 42a).
} 
contexto geral do texto, a apresentação dos principais léxicos evidenciou a predominância de termos e formas verbais pertencentes aos campos semânticos da revelação de Jesus como "Filho de Deus", com características notadamente da literatura joanina, que constituem "o mundo textual" pelo qual o autor intenta explicar a relação Pai - Filho. Quem interpreta o que lê percebe a finalidade prática dos recursos linguísticos expressos por meio dos vocábulos no conjunto do texto e, também, que houve uma deliberada seleção de vocabulário no sentido de exercer influências sobre o leitor. Em outras palavras, o vocabulário do texto em análise afirma a missão e a necessidade de reconhecer Jesus como "enviado" na unidade de ser e de ação com Deus que o enviou ${ }^{254}$. Do que é dito e depreendido do léxico considera-se, segundo a pragmalinguística, a função do ato locutório da linguagem. Configura-se, desse modo, o sentido pragmático do texto que se expressa na estratégia da coesão de seu conjunto lexical.

\subsection{2. \\ Aspectos sintáticos do texto de Jo 5,19-47}

A compreensão dos aspectos sintáticos parte não só do estudo das relações no interior da oração, mas principalmente das relações que se estabelecem no interior de unidades linguísticas mais complexas, compostas de diversas orações ou proposições - como, por exemplo, as sequências -, chegando-se à evidência de que, para as macroestruturas, valem os mesmos critérios que regulam as microestruturas ${ }^{255}$.

Esta etapa diz respeito à forma como os elementos linguísticos presentes na superfície textual $^{256}$ do discurso de Jo 5,19-47 se interconectam, por meio de recursos coesivos lexicais e sintáticos. $\mathrm{Na}$ análise dos aspectos sintáticos do texto, o interesse se concentra sobre os elementos linguísticos que configuram os enunciados enquanto estes constituem um fator importante para determinar a organização formal e o conteúdo comunicativo do discurso.

\footnotetext{
${ }^{254}$ JONGE, M., Les verbes apostel I w e penpw dans le vocabulaire théologique de saint Jean In Id. L'Évangile de Jean sources, rédaction, théologie, Belgique: Leuven, University Press, 1977, p. 389.

${ }^{255}$ MORA PAZ, C. et al., Lectura pragmalingüística de la Biblia, Estella (Navarra): Verbo Divino, 1999, p. 34 et seq.

${ }^{256} \mathrm{O}$ valor da palavra é mais importante que sua significação externa, pois ambas dependem do contexto no discurso para significarem. O valor da palavra é inseparável da sua função. Cf. BIDERMEN, M.-T. C., Teoria linguística, São Paulo: Martins Fontes, 2001, p. 322.
} 
O versículo introdutório ao texto (v. 19) concentra elementos sintáticos que orientam sua configuração: a forma verbal łapekrinato que, seguindo-se das conjunções oufe kai, do pronome autoil' (v. 19a-b), e da expressão adverbial anhnn anhn I egw ù̀nh (v. 19c), define o tipo discursivo do texto, a sua situação comunicativa e ainda indica quem são seus ouvintes ${ }^{257}$. A primeira enunciação (v. 19d) é introduzida pela partícula adverbial negativa ouque, juntamente com o pronome indefinido aden, forma uma proposição apofática, que serve para acentuar o feito extraordinário do sujeito da declaração, identificado pelo sintagma nominal o’ ui òj. Na expressão afN eàutou/a preposição apo, (19d) é usada para iniciar o agente da passiva; ela não tem ideia de finalidade, pois sua função é destacar o agente da ação verbal, que por meio de uma exceção, indicada pela conjunção subordinativa seguida da partícula $n h,(v .19 \mathrm{e})^{258}$, recebe uma concessão: $\mathrm{nh}$, ti $\mathrm{b}$ eph| ton patera poi ounta. O "aquilo" expresso pelo pronome indefinido ti é esclarecido pela expressão “a] gar an’” (v. 19f) ${ }^{259}$. O pronome demonstrativo ekè hoj no v.19f, usado como pronome pessoal (ele), é o sujeito da frase em referência a o` Pathr e põe o acento na distinção de outra pessoa divina, uma vez que a gramática requereria o pronome pessoal outoj (ele).

Quatro conjunções coordenativas gar ${ }^{260}$ estruturam o texto dos versículos 19f-23e. O primeiro gar (pois) introduz a oração do v. 19f, que explica a impossibilidade de o Filho operar independentemente, e a baseia na perfeita filiação de Jesus (19g). O desenvolvimento da ideia é assegurado pelas conjunções aditivas kai. (vv. 19g e 20b). O segundo gar (v. 20a) também é explicativo: explica a causa de o Filho poder fazer o que o Pai faz. A conjunção

\footnotetext{
${ }^{257}$ A conjunção coordenativa conclusiva ouf (porque) é o elemento que conecta a resposta de Jesus à situação de produção do texto; a conjunção coordenativa aditiva kai,(19b - porque) indica o sujeito do verbo el egen bem como o pronome pessoal autroij, que confirma os mesmos destinatários. A expressão adverbial anhn anhn I egw ù̀nhh" (v. 19c), enfatizando a fala do locutor e o pronome pessoal ùñn, identificando a quem ela se dirige, marcam o início do discurso em fala direta.

${ }^{258}$ Cf. ZERWICK, M., Biblical Greek, p. 158.

${ }^{259}$ A partícula ah no v. 19f (em frase subordinada) exprime eventualidade ou possibilidade. Cf. Ibid., p. 109.

${ }^{260} \mathrm{O}$ pensamento do texto grego dos versículos 19 a 23 que se estrutura ao redor de quatro declarações explicativas gar (19f; 20a; 21a; 22a) segue esta linha de raciocínio: é impossível para o Filho realizar uma ação independente e determinada por si mesmo, algo que o colocaria contra o Pai como outro Deus, pois tudo o que o Filho faz coincide com tudo que o Pai faz e é coextensivo a ele. Cf. CARSON, D. A., O comentário de João, São Paulo: Shedd Publicações, 2007, p. 252. Também Léon-Dufour considera o gar do v. 20 explicativo, um esclarecimento como em 3,19; 4,37. 44. Ele o traduz por sim: "Sim o Pai ama o Filho...". Trata-se, portanto, para ele de uma confirmação. Cf. LÉON-DUFOUR, X., Leitura do Evangelho segundo João, p. 38.
} 
i ha no v. 20e, com o sentido de subordinada adverbial final tem a função de esclarecer a finalidade da iniciativa do Pai. O terceiro gar (v. 21a) introduz uma exemplificação da principal verdade articulada nos vv. 19 e 20: pois da mesma forma que o Pai ... As conjunções W\$̣per (v. 21a) e oufwj (21c), formando a expressão comparativa como ... também, têm a função de exemplificar por comparação em que consiste esse "mostrar tudo o que ele (Pai) faz" e que concedeu ao Filho também fazer (vv. 21a-21c). O quarto gar (v. 22a) apresenta mais uma razão e base para as afirmações do v. 21: pois o Pai...

No v. 22a, a partícula negativa oude, em construção com oudena ${ }^{261}$, quer mostrar que há distinção de função no fazer do Pai e do Filho: "O Pai a ninguém julga". A atenção para a novidade atribuída pelo Pai ao Filho é despertada pela conjunção adversativa $a \mathrm{al}$ a, (v. 22b), que significa, propriamente, de maneira distinta: "Mas confiou ao Filho todo julgamento", com a finalidade expressa pela conjunção i hă de que o Filho receba as mesmas honras do Pai. A conjunção subordinativa comparativa kaquj (assim como), no v. 23b, inicia o fechamento do argumento desenvolvido a partir do v. 19d, e, com um reforço retórico com base de um paralelismo, conclui: "Quem não honra o Filho não honra o Pai que o enviou".

Nesta sequência (vv. 19d-23e) chama a atenção a brusca mudança da fala em primeira pessoa (19c) no início do discurso para a terceira pessoa no resto da sequência e a concentração do uso dos termos o ui òj e o’ pathr, que se repetem alternadamente $^{262}$ em cada membro dos paralelismos ${ }^{263}$. Estes termos, além das repetições já mencionadas, estão substituídos por pronomes de terceira pessoa nos seguintes versículos: no v. 19f o pronome demonstrativo ekè hoj subtitui o termo o` pathr; nos vv. 20b e 20d o pronome oblíquo autw/substitui o termo ò ui òj; no v. 20c o pronome pessoal autroj substitui o’ pathr; no v. 23e o pronome auton substitui ò ui g̀j.

A expressão adverbial Anhn anhn l egw ù̀nh se repete no v. 24a (cf. v. 19c) e tem a função de dar destaque a uma nova declaração solene: đđi o ton I ogon

\footnotetext{
${ }^{261}$ Usada geralmente quando a resposta negativa é esperada.

${ }^{262} \mathrm{O}$ termo o' pathr (Pai) se repete nos vv. 19e; 20a; 21a; 22a; 23b; 23d; e o termo o` uiòj (o Filho), nos vv. 19d; 19g; 20a; 21c; 22b; 23a; 23c.

${ }^{263} \mathrm{O}$ autor se utiliza, neste discurso, dos diversos procedimentos do paralelismo bíblico. Para um aprofundamento desta estrutura literária no presente discurso conferir o texto de VANHOYE, A., La composicion de Jo 5,19-30, In Mélanges Bibliques, 1970, pp. 250-274.
} 
nou iniciada pela conjunção subordinativa integrante of̣i (v. 24b), em fala direta e em primeira pessoa: cujo pronome possessivo nou (24b) e o oblíquo ne (24d) associados aos termos I ogoj (palavra) e penpw (enviar) servem à personalização do "Enviado". Nos vv. 24b e 24c a ausência do artigo sinaliza que o sujeito dos dois particípios (akounn e pi steann) é o mesmo: o que escuta é o mesmo que crê. A conjunção adversativa all a, no v. 24g quer expressar ênfase na antítese, acentuando o poder salvífico do "Enviado" do Pai. A preposição \&k no v. 24g (Ek toul canatou) após o verbo nđabai nw no perfeito do indicativo (nđabedhken) tem o sentido de fazer sair; isto é, mudar de uma má situação para uma melhor, concluindo, assim, a declaração asseverativa.

Nova proposição declarativa, em primeira pessoa, no versículo 25a, usando a mesma expressão adverbial łhnn anhn I egw ù̀nh (já utilizada nos vv. 19c e 24a) tem a função de chamar a atenção para o cumprimento da "hora" da realização da promessa (vv. 24b-c-d-e-f-g) de passar da morte para a vida: "Vem a hora e é agora" (vv. 25b e 25c). A partir do v. 25b novamente a fala acontece em terceira pessoa até o v. 29c. A conjunção subordinativa integrante đfi (v. 25b) exprime a certeza do momento, a aditiva kai ,faz a reiteração da hora do momento, e a conjunção ơe no v. 25d, que é subordinativa temporal, tem a função de reforçar a chegada do momento "é agora" (v. 25c).

A explicitação nos versículos 25d, 25e, 25f, da consequência da novidade trazida pela "hora", está direcionada ao futuro: akousantė (ouvirão) e zhsousin (viverão); no entanto, a enunciação dos vv. 26b-27a já é acontecida: "O Pai deu (elWken) ao Filho... deu-lhe autoridade..." (exousi an edhken autw). A combinação das conjunções W\$per e oufwj nos vv. 26a (W\$per) e 26b (oufwj), repetindo a mesma estrutura sintática dos vv. 21a e 21c, indica a razão deste acontecimento que tem " o’ pater" como sujeito da comparação (explícito no v. 26a e oculto no v. 26b). A oração subordinativa causal (v. 27b ) iniciada pela conjunção ợi tem como sujeito o ù ùj, substituído no v. 27a pelo pronome demonstrativo autw/e tem como predicativo do sujeito a expressão "Filho do Homem"; por isso não está antecedida do $\operatorname{artigo~}^{264}$. A declaração anunciada a seguir no v. 28a, em construção com a partícula negativa nh, vem introduzida por outra conjunção subordinativa

\footnotetext{
${ }^{264}$ A expressão "Filho do Homem" sem ser antecedida do artigo acontece somente aqui e em Dn 7,13 .
} 
ofi funcionando como um cólon explicativo da enunciação. No v. $28 \mathrm{c}$ a

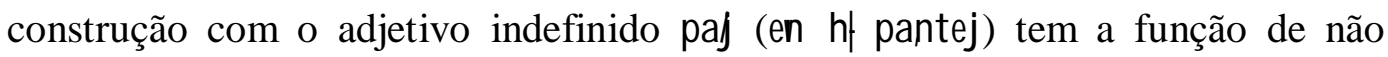
apresentar nenhuma restrição (como acontece no v. 25d) à promessa de outra "hora" que futuramente virá, relacionada a uma ressurreição de vida e uma ressurreição de julgamento (as formas verbais dos vv. 28d e 29a estão no futuro), para os que jazem no sepulcro.

No v. 30a, uma proposição formulada em primeira pessoa e em linguagem direta retoma a questão do julgamento que o Pai confiou ao Filho (cf. v. 22b) e que, por estar em paralelismo com a mesma enunciação do v. 19d, "ouvdunatai egw.poi ėh af/Vènautou/ adden", quer indicar que o julgamento é uma das funções do Filho. Aqui o pronome pessoal de primeira pessoa do singular egw, substitui “o” ui g̀j" do v. 19d, apresentado na terceira pessoa do singular. O uso enfático do pronome egw, (v. 30b), da expressão afVenautou/(v. 30a) e do possessivo eahn, (v. 30c), juntamente com as formas verbais dos vv. $30 \mathrm{~b}$ e $30 \mathrm{~d}$ em primeira pessoa, tem, pois, a função de identificar o falante do pronome egw, com "o Filho". À declaração feita sobre o julgamento (v. 30b) é acrescentada, por meio da conjunção kai , sua qualidade (justo), que identifica sua origem; e a explicação da razão de seu agir é introduzida pela conjunção subordinativa causal ofii, sendo a ideia reforçada por contraste pela partícula adversativa ałla, (v. 30e). Esta proposição do v. 30 em paralelismo com o v. 19d fecha, portanto, o pensamento que sustentou os argumentos sobre a declaração "andunatai ò uiòj poi eih affV èutoulouden".

Uma proposição condicional expressa pela conjunção subordinativa Æn, com o verbo marturen no subjuntivo (v. 31a) $)^{265}$, vem introduzir a ideia do "testemunho" que será desenvolvida até o v. 39d, sempre em primeira pessoa. No v. 32a o pronome al I oj (outro) ${ }^{266}$ será identificado nos vv. 37a e 37b com o Pai, que testemunha em favor de Jesus. Esta identificação é enfatizada pelo kai , inicial (v. 32b), que corresponde a um "sim". A origem e a direção do "receber

\footnotetext{
${ }^{265}$ Essa construção sintática empregada pelo evangelista, frequentemente é usada para designar aquilo que se espera que suceda em determinadas circunstâncias. O presente do subjuntivo na oração subordinada condicional se refere quase sempre a supostos que se dão habitualmente (cf. 8,16). Cf. BALZ, H., verbete In BALZ, H.; SCHNEIDER, G., DENT, p. 1111.

${ }^{266} \mathrm{O}$ pronome al I oj (outro) usado quando se nega a existência ou inclusive a possibilidade de que se possa pensar em "outro" da mesma índole, em algo semelhante ou algo equivalente: se se nega a existência de um, então tem que excluir a outro. Cf. WEIB, K., Verbete al I oj In BALZ, H.; SCHNEIDER, G., op. cit., p. 188.
} 
testemunho" são reforçadas pela preposição para, (v. 34a) ${ }^{267}$. O pronome demonstrativo ekei hoj é o sujeito do v. 35a referindo-se ao acusativo (Wwannhn), objeto direto do v. 33a. Porém, nos versículos 37b e 38b, o pronome demonstrativo ekè hoj refere-se ao Pai que foi citado anteriormente (v. 37a). No v. $37 \mathrm{c}$ o advérbio oute (nunca), como conjunção copulativa, se repete no v. $37 \mathrm{~d}$ continuando a negação anterior numa construção em paralelismo.

Nova ideia estruturada de forma negativa com o advérbio ouk(v. 40a) sobre a causa da rejeição é desenvolvida por meio de uma enfática contraposição com a conjunção aM a,(v. 42a), ensejando a conclusão do pensamento (v. 42b) com a conjunção subordinativa ợi, funcionando como um cólon. A proposição positiva do v. 43a com o enfático egw, enseja, pela conjunção adversativa kai ,(v. 43b), uma confissão de contrários, que abre a possibilidade de prosseguir com numa oração subordinada condicional (v. 43c) a ideia da rejeição iniciada no v. 40a.

Com o advérbio pwj no v. 44a se inicia uma nova estrutura frasal com o verbo pisteum (pisteubai) que se fecha, como numa inclusão, com o mesmo advérbio no v. 47b, e com a mesma ideia de rejeição. A partícula negativa nh, que inicia o v. 45a tem a função de manifestar a simples intenção de quem fala. A conjunção subordinativa integrante ođi no v. $45 \mathrm{~b}$ depois da forma verbal dokėte indica percepção, através da mente, ${ }^{268}$ da situação dada. O sujeito da frase do v. 45 c é o particípio kathgorwh e não Moisés, que é o predicativo do sujeito. A preposição ejj com acusativo no v. $45 \mathrm{~d}$, usada com pessoas (o pronome relativo on refere-se a Moisés), serve para caracterizar o centro da esperança dos interlocutores $^{269}$. Nova oração condicional (v. 46a), aqui com a conjunção ė,vtem a função de expressar a possibilidade da enunciação, reforçada pela partícula an (v. 46b), que, depois do verbo no imperfeito, tem a função de formação do futuro do pretérito, exprimindo possibilidade ou irrealidade no passado ${ }^{270}$; já no v. $47 \mathrm{a}$, a mesma conjunção subordinativa condicional ė,vseguida da partícula de, introduz

\footnotetext{
${ }^{267}$ De modo enfático no v. 34a e em v. 43a é sublinhado o pronome pessoal egw, é um "eu" cristológico, é uma palavra para indicar a identidade reveladora de Jesus. Geralmente em seu uso, no Evangelho de João, subjaz uma ideia cristológica de revelação: "Eu próprio", o que fala, testifica. Cf. JAUBERT, A., Leitura do Evangelho segundo João, São Paulo: Paulinas, 1982, p. 75.

${ }^{268} \mathrm{~A}$ conjunção subordinativa integrante $\mathfrak{a} \mathrm{i}$, no sentido de "que", indica o conteúdo ou objeto, depois de verbos que significam percepção através da mente ou dos sentidos, o ato de crer, pensar, julgar, esperar. Cf. KLEINE, H., Verbete ofi In BALZ, H.; SCHNEIDER, G., DENT, p. 617.

${ }^{269}$ Cf. ELLIGER, W., Verbete eij In BALZ, H.; SCHNEIDER, G., op. cit., p. 1211.

${ }^{270}$ Esta partícula, em certas construções, é indicativa de contingências. Cf. RUSCONI, C., Dicionário do grego do Novo Testamento, São Paulo: Paulus, 2003, p. 38.
} 
uma oração interrogativa indireta. A preposição peri, no v. 46c seguida da conjunção gar tem o sentido de "referente a" e, neste sentido, peri,segue a forma verbal egrayen (escrever), que, com genitivo, designa o objeto ou a pessoa à qual se dirige uma atividade, portanto, aos referentes do pronome eadj'. Os vv. 44a47b constituem a conclusão dos argumentos da sequência dos vv. 31a-47b.

Destaca-se claramente nos vv. 31-47 a alternância das formas pronominais de segunda pessoa do plural $^{271}$ com o pronome pessoal de primeira pessoa do singular egw, (vv. 34a, 36a, 43a) e outras formas pronominais também de primeira pessoa, além das formas verbais que lhe são correspondentes. Na sequência que começa no v. 44a até o v. 47b há uma excessiva presença de formas verbais em segunda pessoa do plural $^{272}$ indicando, além da fala direta, a insistência no acolhimento do que é dito. Corrobora essa insistência as orações subordinadas adverbiais finais com a conjunção i ha (vv. 34c, 36c, 40b).

A conclusão disto é que os aspectos sintáticos sinalizaram para uma estrutura linguística na qual as ideias que compõem o discurso são expressas em blocos de sequências que se desdobram passo a passo, por meios de conectores, no ritmo do paralelismo ${ }^{273}$, nas quais elas são ancoradas literariamente.

Os sinalizadores sintáticos dividem o texto em três partes conectadas entre si: 1) vv. 19a-19c; 2) vv. 19d-30e; 3) vv. 31-47.

1) Uma introdução em dois momentos distintos marcados pela forma verbal apokrinato (vv. 19a-b), que apresenta o locutor, e a expressão adverbial anhn anhn I egw ù̀nh (v. 19c), que inicia a fala do locutor do texto.

2) Uma seção construída na base do paralelismo (vv. 19d-30e) responde pelo alto índice de recorrências, notadamente, dos sintagmas nominais ${ }^{274}$ o`Pathr e o ui ùg e pelo repetido uso dos pronomes indefinidos na sequência que vai do v. $19 \mathrm{~d}$ ao v.

\footnotetext{
${ }^{271}$ Segunda pessoa: vv. 34c, 35c, 38c, 39b, 43d, 44a, 45b, 45c, 45d, 47b. De primeira pessoa: vv. 31a, 31b, 32a, 32d, 36b, 36e, 36f, 37a, 37b, 39d, 40a, 43a, 43b,46b, 46c, 47b.

${ }_{272}$ Oito formas verbais: vv. 44b, 44c, 45a, 45d, 46a, 46b e 47a, 47b.

${ }^{273}$ Sobre a estrutura de paralelismo pode-se consultar o artigo de VANHOYE, A., La composicion de Jo 5,19-30, In Mélanges Bibliques, 1970, pp. 250-274; Conferir também FERRARO, G., Il Paraclito, Cristo, Il Padre nel Quarto Vangelo, Cidade do Vaticano: Editrice Vaticana, 1996, p. 142.

${ }^{274}$ Os sujeitos em todo o texto, quando não explicitados pelos sintagmas nominais "o`Pathr " e "o" uiòj”, apresentam-se através de pronomes pessoais, oblíquos, reflexivos, demonstrativos, relativos e indefinidos à exceção dos versículos 19a cujo sujeito é Jesus e $45 \mathrm{c}$ que tem como sujeito okathgor wh O pronome demonstrativo ekei hoj se repete nos vv. 19f, 35a, 37b, 38b, 39c, 43d, 46c, $47 \mathrm{a}$, porém nos vv. 19f, 37b, 38b se refere ao Pai tendo, portanto, a função do pronome pessoal de terceira pessoa.
} 
30a e que estão em correlação direta com o Pai e o Filho ${ }^{275}$. No v. 30e, fecha-se o pensamento iniciado no v. 19d, no qual se enfatiza que a filiação perfeita envolve perfeita identidade de vontade e ação com o Pai e em cujo momento foram reveladas características especificamente relacionadas à relação Pai-Filho.

3) Os vv. 31-47 formam nova seção, também toda estruturada em paralelismo, que se constitui de duas sequências (vv. 31a-39d e vv. 40a-47b), nas quais se destaca a dimensão da relação pessoal histórica do Filho com os homens, e que agora se apresenta em primeira pessoa com o enfático pronome egw, $w^{276}$.

a) $\mathrm{Na}$ sequência compreendida nos vv. 31a-39d a ideia apresentada tem como elemento sintático básico a forma verbal narturw/ e o substantivo correlato narturia. Nessa sequência, a relação é feita por meio da alternância entre os pronomes pessoais de primeira pessoa do singular e os de segunda pessoa do plural $^{277}$, além das conexões com as conjunções kai, all a, i ha, gar, oute ofi .

b) A sequência textual entre os vv. 40-47 desenvolve a ideia da recepção da palavra do falante. Os elementos sintáticos responsáveis por esta sequencialidade, além dos pronomes pessoais de primeira pessoa do singular e segunda pessoa do plural, são as conjunções kai, aMla, ė,yo advérbio pwj' e os verbos I anbanw, pi steun, er conai .

\footnotetext{
${ }^{275}$ Os pronomes indefinidos: nada (auden vv. 19d; 30a), tudo (tauka 19f), todo (pałan 22b), todos (pantej vv. 23a, 28c), ninguém (andena v. 22a). O pronome ouden (vv. 19d e 30a) está em paralelismo com panta (vv. 20b e 30a); no v. 19d na qual o pronome ouden (v. 30a) está em paralelismo com panta (vv. 20b e 30a). Outro aspecto do texto que chama a atenção é a grande incidência de frases negativas, com o advérbio "ầ, ou com a partícula de negação nh, ou também o pronome indefinido ouden ou ainda a conjunção oute vv. 19d; 23c, 23d; 24f; 28a; 30a; 30d; 31b; 34a; 37c; 37d; 38a; 38c; 40a; 41; 42b; 43b; 44c; 45a; 47a.

${ }^{276} \mathrm{O}$ uso enfático do pronome pessoal de primeira pessoa egw, a partir do v. 30a. As outras passagens do uso enfático do pronome pessoal de primeira pessoa egw, encontram-se nos vv. 30a, 31a, 34a, 36a, 43a. Outros pronomes de primeira pessoa aparecem 22 vezes: nou (vv. 24b, 31b, 43a), ne(vv. 24d, 30e, 36f, 37a, 40a, 43b), exautou/(vv. 30a, 31a ), eah,,(v. 30c), exon (v. 30d), exouv (vv. 32a, 32d, 36e, 37b, 39d, 46c), noi (v. 36b), exoi , (v. 46b), e90i' (v. 47b).

${ }^{277} \mathrm{O}$ elevado número de pronomes, de segunda pessoa do plural nesta sequência merece destaque: vv. 33a, 34c, 35c, 38a, 38c, 39b, 42a, 44a, 44, 45b, 45d; bem como, chama atenção a abundância do tempo verbal em segunda do plural no texto que está entre os vv. 33a, 34c, 35c, 37c, 37d, 38a, 38c, 39a, 39b, 40a, 40b, 42b, 43b, 43d, 44b, 44c, 45a, 45d, 46a, 46b e 47a, 47b.
} 


\subsection{3.}

\section{A coesão remissiva e/ ou referencial}

A Coesão remissiva ou referencial ${ }^{278}$ desempenha quer a função de (re)ativação de referentes (remetem ou permitem recuperar), quer a de "sinalização" textual (cuja função é de organizar o texto fornecendo ao interlocutor "apoios" para o processamento textual). O discurso é todo estruturado, tanto no detalhamento das frases, quanto no todo de sua composição, segundo o procedimento do paralelismo bíblico, o que justifica a grande ocorrência de repetições com variações significativas na mesma sequência. A reativação de referentes no texto é realizada por meio da referenciação ${ }^{279}$ anafórica ou catafórica, formando-se, deste modo, cadeias coesivas mais ou menos longas. O discurso de Jo 5,19-47, em seu versículo introdutório (v. 19), apresenta alto índice de referências ao texto antecedente (5,1-18), além de sinalizações que presidem o processamento textual.

\section{Introdução ao discurso: vv. 19a - 19c:}

No texto que se inicia no v. 19a uma fala indireta e em terceira pessoa apresenta Jesus respondendo a uma interpelação exofórica (v. 19a): Apekrinato ouf o' Vhsail. O uso da forma verbal apekrinato, reforçada pela conjunção ouf que faz a ligação com o contexto antecedente, denota reação verbal à interpelação de 5,16 e 18, permitindo recuperar o referente que motivou a resposta. A identificação de Jesus como aquele que realiza o ato de responder faz remissão à situação comunicativa do contexto de 5,17 (Jesus respondeu...). O pronome pessoal de terceira pessoa do plural ${ }^{280}$ autroil (v. 19b) tem como referente os

\footnotetext{
${ }^{278}$ A referenciação consiste na construção e reconstrução do objeto do discurso; diz respeito, sobretudo, às operações efetuadas pelos sujeitos à medida que o discurso se desenvolve. São elementos de referência os itens da língua que não podem ser interpretados semanticamente por si mesmos, mas remetem a outros itens do discurso necessários à sua interpretação. Como formas de remissão a elementos anteriormente apresentados no texto ou sugeridos pelo co-texto precedente, as referências possibilitam a sua (re) ativação na memória do interlocutor, ou seja, a alocação ou focalização na memória ativa (ou operacional). Cf. KOCH, I. V., Introdução à linguística textual, São Paulo: Martins Fontes, 2009, p. 58 seq.

${ }^{279}$ A referência pode ser pessoal, demonstrativa, comparativa (os elementos de ordem gramatical como os pronomes de terceira pesssoa - retos e oblíquos -, demonstrativos, indefinidos, relativos, interrogativos; os numerais, o artigo e alguns advérbios); a substituição (nominal, verbal, frasal; quando um elemento linguístico substitui uma expressão precedente); e a elipse (nominal, verbal, frasal); e parte da coesão lexical: a reiteração (que se realiza por meio de repetição de um referente textual pelo uso dos mesmos itens lexicais: sinônimos, hiperônimos, uso de nomes genéricos e expressões nominais). Cf. Ibid., p. 36.

${ }^{280}$ A referenciação pode realizar-se por intermédio de formas gramaticais que exercem a "função pronome". A função dos pronomes é mostrativa (não têm a função de nomear), sendo eles os
} 
interlocutores de 5,18 identificados pelo sintagama nominal oi Voudai $\boldsymbol{b i}^{281}$, realizando, assim, uma referência remissiva anafórica por substituição. Somente, no versículo 19c, Jesus inicia, com uma expressão solene em primeira pessoa do singular ( $\mathrm{eg} \mathrm{w}$ ), sua fala, dirigindo-se aos ouvintes pelo pronome pessoal uǹnh (v. 19c). O uso deste pronome em fala direta sinaliza para uma nova situação comunicativa, que tem como referente os mesmos interlocutores de 5,18: $\mathbf{a}^{\backslash}$ Voudai $\not \dot{d}^{282}$. A conjunção coordenativa kai,(v. 19b) ao estabelecer que o sujeito do verbo el egen (kai . el egen autroi j’) é o mesmo da oração anterior (v. 19a) realiza uma remissão por elipse a fim de dar sequência à fala. O pronome indefinido ouden no v. 19d que tem como referente anafórico o termo evgazetai de 5,17, bem como o pronome indefinido ti (v. 19e) que faz referência ao trabalho mencionado em 5,17 , reforçam a coesão remissiva. Da mesma forma os sintagmas nominais o’ uioj (v. 19d) e o’ pathr (v. 19e) fazem referências remissivas anafóricas a 5,17.

\section{a) Primeira sequência: vv 19d-30e}

Vv. 19d-23e

A preposição apo, (v. 19d) na expressão poi eih aflV eàutoul ouden (nada fazer por si mesmo) tem como referente anafórico a expressão ison èuton poi wh tW/ qew/' de 5,18. Também o uso do advérbio oǹi wi (v. 19g) em relação com o adjetivo ison de 5,18 constitui-se numa estratégia de referenciação pela

instrumentos básicos da situação do diálogo e da comunicação entre emissor e receptor. Situam os seres e as coisas (elementos centrais da comunicação) em relação ao espaço (universo externo), ou com relação ao tempo. Nessa classe dêitica estão incluídos os pronomes pessoais, os pronomes demonstrativos, relativos e alguns advérbios de lugar e de tempo. O seu valor linguístico é duplo: tanto tem a função gramatical, como significado espacial. Cf. BIDERMEN, M.-T. C., Teoria linguística, p. 322.

${ }^{281}$ O referente é fabricado pela prática social. Interpretamos e construimos nossos mundos através da interação com o entorno físico, social e cultural. Aqui os atores são categorizados como "os judeus". Ingedore diz: "no quadro etnometodológico, se propõe estudar a categorização como um problema de decisão que se coloca nos atores sociais, de forma que a questão não seria avaliar a adequação de um rótulo "correto" para um objeto de mundo, mas descrever os procedimentos linguísticos e cognitivos por meio dos quais os atores sociais se referem uns aos outros, por exemplo, categorizando alguém como "um velho", "um banqueiro", "um judeu”. Tais variações no discurso poderiam ser interpretadas como dependendo muito mais da pragmática da enunciação que da semântica dos objetos. As categorias para descrever o mundo alteram-se, tanto sincrônica quanto diacronicamente: quer nos discursos ordinários quer nos discursos científicos, elas são plurais e mutáveis, antes de serem fixadas normativa ou historicamente. Cf. KOCH, I. V., Desvendando os segredos do texto, São Paulo: Cortez, 2011, p. 42.

${ }^{282}$ A intervenção dos judeus (v. 18) está sob a forma de discurso indireto. 
reativação da memória imediata operacional do elemento objeto-da-resposta. Também o pronome indefinido taưa(v. 19f) realiza uma referência remissiva por substituição a 5,16 (đđi tauka €øoi è).

A coesão remissiva por reiteração está patente pela repetição da mesma forma verbal poien no v. 19 (vv. 19d, 19e, 19f, 19g) ${ }^{283}$, que faz referências anafóricas às formas verbais de 5,16 (eqoi é ea sabbatw) com o sentido de fazer as obras do sábado e de 5,18 (ison eàuton poi wh tw/ qew/ com o sentido de fazerse igual a Deus. Também o pronome demonstrativo đkè hoj (v. 19f) faz referência anafórica por substituição ao sintagma nominal o` pathr (v. 19e) e catafórica ao sintagma nominal ò uì̀ (v. 19g).

Portanto, constata-se que no versículo $19 \mathrm{~d}$ a reativação de referentes no texto, realizada por meio das referenciações anafóricas e catafóricas, construiu “cadeias coesivas" e sinalizou para a criação de novos "campos lexicais". Aquelas que retomam referentes principais ou temáticos (o motivo da resposta, os interlocutores, a situação comunicativa) que percorrem o texto inteiro e estes que respondem pelo alto nível de informatividade textual (o acontecer da relação filial de Jesus, o Filho, com Deus, o Pai).

As marcas linguísticas coesivas deste conjunto de frases (vv. 19d-23e) assinalam a ampliação da ideia central por meio de novas relações de sentido. A conjunção gar do v. 20a (porque ou pois) em função anafórica faz a relação com os vv. 19f e19g. Na nova situação comunicativa, também o pronome indefinido panta (tudo v. 20b) tem a função de remeter ao taưa (tudo) do v. 19f reforçado pela reiteração da forma verbal poi ė/(do v. 20c).

O pronome pessoal de terceira pessoa autroj (v. 20c) que é o sujeito de poiej/ (a; autroj poi eił faz referência a o’ pathr (v. 20a). O "fazer" do Pai na memória dos interlocutores é apresentado como "obras". Porém o termo erga (v. 20d) na expressão kai. neizona toutun dexi autw/ erga faz referência remissiva anafórica ao agir de Jesus e se refere "às tais coisas" que Jesus fazia no sábado de 5,16 (đi taưa €øoi बi) porque se encontra em estreita relação remissiva anafórica com as formas verbais exgazeai e exgazonai de 5,17b. O pronome pessoal de segunda pessoa do plural uǹđil' no v. 20e tem a mesma função que tem no v. 19c

\footnotetext{
${ }^{283} \mathrm{O}$ verbo poi en é usado neste texto 10 vezes incluindo sua forma composta zuppoiei/no versículo $21 \mathrm{~b}$ e $21 \mathrm{~d}$. O uso de poi en no infinitivo presente ativo tem o sentido de fazer criativo, criar, tirar do nada, produzir.
} 
(ù̀nh): dá continuidade à linguagem direta. A presença da forma verbal egè ré (levanta), no v. 21a, realiza uma coesão remissiva por reiteração ao versículo 8 do texto antecedente: I ege autw/ o' Vhsail egeire afon ton krabatton sou kai . peri pate $(5,8)$.

\section{24}

A coesão remissiva no v. 24a se dá por meio da reiteração da fórmula introdutória da fala de Jesus do v. 19c: anhnn anhn I egw uǹnh realizando também uma remissão catafórica ao sinalizar para uma nova comunicação. Os termos “ZWh"' (vv. 24e e 24g) e "krișij” (v. 24f) constituem elementos parafrásticos dos vv. 21a-22b. O sintagma nominal o’ pathr é o referente da forma remissiva pronominal da frase tw/ penyanti, n巴(v. 24d). Os pronomes pessoais de primeira pessoa do singular nou(v. 24b) e ne(v. 24d) fazem referência por substituição ao autor da asseveração do v. 19c que continua falando no v. 24a.

Vv. 25-30:

A reiteração no v. 25a da expressão anhnn anhn I egw ù̀nh dos vv. 19c e 24a a caracteriza como uma fórmula introdutória que sinaliza para nova comunicação. A relação remissiva com a sequência anterior acontece por meio das conjunções W\$sper (no v. 26a) e oufwj (v. 26b) que formam a expressão comparativa como... assim também, reiterando a comparação W\$̣per e oufwj dos vv. 21a e 21c. Novas reiterações acontecem com os sintagmas o’ pathr (v. 26a com o v. 21a) e ò uiò (v. 26b e 27a no qual o pronome autw/ substitui 'o Filho' do v. 21c), zwh,(v. 26a com o v. 21c), krișij (v. 26a com 22b), oi 'nekrai, (v. 25c com 21a), poièn(v. 27a com 21b) além das formas verbais akousousin (vv. 25d, 25e) e zhsousin (25f) que fazem referência anafórica respectivamente com os vv. 24b, e 21 b.

A relação remissiva no v. 30a se realiza pelo pronome pessoal em primeira pessoa egw, que tem como referente o sintagma nominal o’ uiòj do v. 19d. A coesão remissiva acontece também pela reativação no v. 30a em primeira pessoa, das expressões, "por mim mesmo" e "nada posso fazer": Ouvdunanai egw. poi ei h apl exautou/ ouden que fazem referência ao versículo 19d. Outra referenciação vem da forma verbal penyantoj (30e) que remete anaforicamente aos vv. 23e, e 
24d e cataforicamente aos vv. 36f e 37a, 38b. A forma verbal krinw do v. 30c faz referência anafórica aos vv. 22a, 22b, 24f, 27a, 29c.

\section{b) Segunda sequência: vv. 31-39d; 40-47}

Vv. 31-39d:

O pronome pessoal de primeira pessoa egw, (v. 31a) tem como referente o mesmo falante do v. 30a, mas por vir seguido da expressão peri. exautou/(v. 31a, aqui em primeira pessoa) faz remissão à mesma expressão ea ęutw/(vv. 19d, 26a, 26b) em terceira pessoa, e principalmente ao sintagma nominal o’ uiòj dos versículos 19d e 26b. Também o pronome oblíquo em primeira pessoa nou que segue a h’ narturia, reforça esta remissão. O pronome all oj do v. 32a faz remissão catafórica ao sujeito do v. 37b, que é o pronome ekei hoj, o qual substitui o sujeito o’pathr do v. 37a. O sintagma nominal o` pathr (vv. 36b, 36f, 37a; 38a; 38b) remete aos vv. 19e, 20a, 21a, 22a, 23d, e é o referente das formas remissivas pronominais em terceira pessoa dos vv: 24d; 27a; 32a; 37b; 38b. Nos vv. 36b e 36d o léxico erga faz referência anafórica ao v. 20d. O termo alkhohi (v. 31b) também faz remissão catafórica aos vv. 32c e 33b (alhqeia). A expressão o’ penyaj ne do v. 37a faz referência anafórica aos vv. 23e, 24d, 30e, 36f (aqui, no v. 36f a forma é apestal ken) e catafórica ao v. 38b (cuja forma verbal usada é apestė I en). A expressão Zwhn ai wni on (vida eterna) do v. 39b está em referência anafórica com o v. 24c.

Vv. $40 a-47 b$

No v. 40b zWh,(vida) faz remissão anfórica aos vv. 21c, 24g, 26a, 29b. O termo doxa do v. 41 faz remissão anafórica à forma verbal ti naw do v. 23 e catafórica ao v. 44b. A forma verbal gnw\$kw (v. 42a) faz remissão à forma verbal oi do v. 32b e a expressão agaphn tou/ geou/(amor de Deus) remete ao v. 20a: pathr fil ė/ton ui òn (o Pai ama o Filho). O verbo erconai (v. 43a) faz remissão ao verbo penpw do v. 23e e 24d. O verbo pistean (v. 44a, 46b, 47a, 47b) faz referência ao versículo $24 \mathrm{c}$. 


\subsection{4. A coesão sequencial}

A análise do progresso textual ou sequenciação se realiza por meio de recursos linguísticos e de atividades formulativas que o locutor opta por introduzir no texto, de diversas ordens, e que podem ser constatadas entre segmentos do texto $^{284}$. A coesão sequencial se faz através de dois procedimentos: a recorrência e a progressão ${ }^{285}$.

- Análise dos vv. 19-23:

O locutor, ao introduzir o texto com a forma verbal apekrinato (v. 19a), quis destacar o elemento coesivo responsável pela sequenciação e progressão da comunicação a ser feita: ler o texto como uma justificativa da declaração feita por Jesus no v. 17 do texto antecedente. A forma solene e pessoal da expressão adverbial anhn anhn I egw uǹnhh (v. 19c) destaca a função da proposição inicial do discurso (v. 19d) que é apresentar um conteúdo que permita explicitá-lo. Em seu desenvolvimento, os marcadores linguísticos, como as conjunções gar (vv. 19f; 20a), kai , (vv. 20b; 20d), wșper (v. 21a), oufwj (v. 21c), aM a, (v. 22b) i ha (v. 23a), vão estabelecendo entre os vários segmentos textuais diversos tipos de relações semânticas e/ou pragmático-discursivas, que explicitam por causalidade, comparação ou finalidade a enunciação do v. 19d fazendo, assim, o texto progredir. Também há recorrências de itens lexicais como o` ui òj (vv. 19d;19g; 20a, 21c; 22b; 23a, 23c), o pathr (vv. 19e; 20a, 21a, 22a, 23b; 23d) e de formas verbais recorrentes como poien (vv. 19d; 19e; 19f, 19g, 20c; 21b; 21c; apresentando-se nos vv. 21b e 21c em sua forma composta zuppoi ėy, ti naww (vv. 23a, 23b, 23c, 23d). Pode-se constatar também recorrência de estruturas sintáticas, tais como o paralelismo (vv. 19f-19g; 21a,- 21b-21c; 23a-23b; 23c-23d), a paráfrase (vv. 19d-19e) ${ }^{286}$. A expressão verbal "que o enviou" vai proporcionar a

\footnotetext{
${ }^{284}$ A progressão textual diz respeito aos procedimentos linguísticos por meio dos quais se estabelecem, entre segmentos do texto (enunciados, partes de enunciados, parágrafos e mesmo sequências), diversos tipos de relações semânticas e/ou pragmático-discursivas, à medida que fazem o texto progredir.

${ }^{285}$ KOCH, I. V., A coesão textual, São Paulo: Contexto, 2010, p. 48.

${ }^{286}$ A recorrência tem por efeito trazer ao enunciado um acréscimo de sentido, que ele não teria se o item lexical fosse usado somente uma vez. A presença de elementos de recorrência no texto produz um efeito de intensificação, de ênfase. Ressalte-se que não existe jamais uma identidade de sentido entre os elementos recorrentes, cada um deles traz consigo novas instruções de sentido que se acrescentam às do termo anterior. Cf. KOCH, I. V., Desvendando os segredos do texto, p. 122.
} 
sequenciação textual por meio da relação semântica com o v. 24d que fará o texto progredir.

- Análise do v. 24

No enunciado do v. 24, cuja proposição é feita em primeira pessoa, a continuidade de sentido com o segmento anterior é garantida pela expressão "aquele que me enviou", e com o texto pela expressão anhn anhn I egw uǹnh (v. 24a), que tem forte relação semântica com o v. 19c, assinalando que este segmento do texto é parte integrante da resposta (v. 19a), estando, portanto a serviço da progressão da ideia do v. 19d. Há ainda outros elementos sintáticos (os léxicos vida/morte e julgamento dos vv. 24c, 24f, 24g) e semânticos (escutar minha palavra, crer no que me enviou, passar da morte à vida vv. 24b, 24d, 24e, $24 \mathrm{~g}$ ) neste versículo que fazem o texto progredir.

- Análise do v. 25

Pela terceira vez o locutor opta por realizar a sequencialização do texto por meio da expressão anhn anhnn I egw ừnh (v. 25a) ao trazer no enunciado que compreende os vv. 25-29, em dois momentos distintos, uma comunicação absolutamente original (vv. 25a-27b) e reativar uma outra comunicação já conhecida dos ouvintes (vv. 28a-29c). Nesta parte do texto que se prolonga até o v. 30e o sequenciamento por conexão é feito por meio das conjunções que permitem a explicitação do enunciado ofi (vv. 25b; 27b; 28b), kai ,(vv. 25c; 25e; 27e; 29a), W\$per (no v. 26a) e oufwj (v. 26b), que formam a expressão

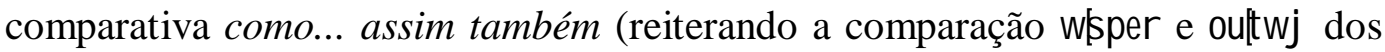
versículos 21a e 21c) e da preposição ejj que costuram o desenvolvimento da ideia, alcançando seu fim nos paralelismos sintáticos dos vv. 30b-30c e 30d-30e. A forma enfática como aparece, pela primeira vez no texto, o uso do pronome pessoal de primeira pessoa do singular egw, (v. 30b) além de ser indício de uma nova enunciação, sinaliza para a relação de sentido com o início do discurso (v. 19d), no qual a proposição igualmente apófática é enunciada em terceira pessoa. Pela estrutura de paralelismo entre as duas proposições e pelo uso da expressão verbal "do que me enviou" pode-se constatar a insistência do falante (egw) na 
identificação dos dois em uma só pessoa: a do Filho com a do atual falante ${ }^{287}$. A conectividade da progressão textual se realiza por meio das conjunções causal of̣i e da adversativa all a, que fecha o pensamento. A frase na qual o autor usa duas vezes o pronome possessivo constitui-se a conclusão da perícope: kai . h krișij h` eah. dikaia estink ofi ouvzhtw/ to. qel hma to. exon alla. to. qel hma tow penyantoj ne (vv. 30c-30e) $\AA$

- Análise dos vv. 31a- 39d

Os vv. 31a-39d apresentam uma sequência cuja conectividade acontece por meio de estruturas sintáticas recorrentes (paráfrases e paralelismos) nas quais a ideia apresentada tem como elemento coesivo básico o item lexical marturia (recorrente nos versículos: 31b, 32c, 34a, 36a) e a forma verbal narturen recorrente nos versículos (vv. 31a, 32a, 32d, 33b, 36e, 37b, 39d). Nesta sequência a relação é feita por meio da alternância entre os pronomes pessoais de primeira pessoa do singular e os de segunda pessoa do plural.

- Análise dos vv. 40a-47b

A sequência textual que está compreendida entre os vv. 40a-47b desenvolve a ideia da recepção da palavra do falante, tendo como elementos sintáticos responsáveis por esta sequencialidade as formas verbais erconai (vir) I anbanw (receber) e pisteun (crer), além dos pronomes pessoais de primeira pessoa do singular e segunda pessoa do plural, conectados pelas conjunções kai , all a, ė,ve o advérvio pwj' que em forma de inclusão dá fechamento ao discurso.

Conclusão

Pode-se, pelos critérios acima demonstrados, assegurar que os padrões léxicos e sintáticos se repetem no contexto coesivamente estabelecendo uma base maior de significado e que as relações estabelecidas pelos procedimentos linguísticos do texto não apenas permitem sua coesão, mas também constroem sua continuidade de sentidos.

\footnotetext{
${ }^{287}$ Outra construção paralela: no v. 30b o verbo akoum faz paralelo com o verbo bl epw do v. 19e. Já nos vv. 30d-30e o paralelismo acontece por meio da expressão "não procuro minha vontade" com "tudo que este faz, o Filho faz de modo semelhante" dos vv. 19f-19g.
} 


\section{3.}

\section{A coerência textual}

A coerência está no processo que coloca texto e usuários em relação numa situação comunicativa. $\mathrm{O}$ que é dito deve ser considerado dentro do conjunto do diálogo, como algo que é pensado, isto é, que é parte de um processo comunicativo que comporta um horizonte maior do que o texto em $\mathrm{si}^{288}$. Se há uma unidade de sentido no todo do texto quando este é coerente, então a base da coerência textual é a continuidade de sentidos entre os conhecimentos ativados pelas expressões do texto.

\subsection{1.}

\section{Fatores de coerência textual}

O texto de Jo 5,19-47 será examinado a partir dos principais fatores de coerência $^{289}$ com recurso a elementos linguísticos ${ }^{290}$ e contextuais $^{291}$ - em particular os de ordem sociocognitiva e interacional.

Os elementos linguísticos da enunciação que inicia o discurso, tais como a forma verbal, a conjunção e a designação do nome, são fundamentais para situar a comunicação a ser proferida, sobretudo porque a conjunção ouf relaciona a resposta de Jesus com a situação que gerou tal necessidade $(5,17)$. Portanto, a frase introdutória apekrinato ouf o’ Vhsoil (v. 19a) é fundamental para a construção da coerência porque determina o sentido da sequência, constituindo-a em texto, e além disso, é indicativa do tipo de texto. No desenvolvimento do discurso encontramos outros elementos linguísticos ${ }^{292}$, entre eles as formas de tratamento, que servem como pistas importantes para a captação do sentido pretendido pelo autor (os pronomes pessoais: uǹं j', egw; o demonstrativo eké hoj e os indefinidos aden, tauka e panta); as conjunções, que exploram uma larga

\footnotetext{
${ }^{288}$ NAY, R. Jahweh im Dialog, Kommunukationsanalytische Untersuchung von Ez 14,1-11 unter Berücksichtigung des Dialogischen Rahmens in Ez 8-11 und Ez 20, Roma: Pontificio Istituto Biblico, AnBib, n.141, 1999, p. 13.

${ }^{289}$ Cf. KOCH, I. V.; TRAVAGLIA, L. C., A coerência textual, São Paulo: Contexto, 2011, p. 71.

${ }^{290}$ O conhecimento dos elementos linguísticos e sua relação com o contexto de situação também é importante para o cálculo do sentido e a percepção de um texto como coerente e podem ser constatados no item 4.2.1.

${ }^{291}$ Tais como: os elementos de conhecimento de mundo, conhecimento compartilhado, inferências, fatores de contextualização, situacionalidade, informatividade, focalização, intertextualidade, intencionalidade e aceitabilidade, consistência e relevância.

${ }^{292}$ Os elementos linguísticos do texto foram exaustivamente demonstrados nos itens anteriores: aspectos léxicos, sintáticos e da coesão.
} 
escala de recursos para contextualizar o que é dito; as preposições, que identificam a origem e direção; os advérbios, que ajudam na ordenação temporal. Além dessas, temos as recorrências de itens lexicais (o` pathr, o’ uiòj), o uso de expressões para distinguir tipos de conteúdo (anhn anhn l egw uǹnhh) e as formas verbais, especialmente poi ėh e narturw/ A mudança de forma literária no v. 24 e na sequência do texto a partir do versículo 30, bem como, a alta incidência de pronomes de segunda pessoa do plural na seção composta pelos vv. 31a-47b, ajudam a captar a continuidade de sentido dos enunciados, permitindo ao leitor/ouvinte seguir as marcas da orientação argumentativa da justificativa para compreendê-la.

O fato de a análise da coesão textual ter identificado um grande número de remissões exofóricas e endofóricas (quer anafóricas, quer catafóricas), recorrências de itens lexicais (o Pai, o Filho, obras, vida, Escrituras), estruturas sintáticas ou esquemas literários (paralelismos, paráfrases, inclusões, quiasmos), fórmulas prontas e frases condensadas (amém, amém, digo-vos; quem escuta minha palavra e crê naquele que me enviou; faz levantar os mortos) ${ }^{293}$; de nomes de pessoas conhecidas (João Batista, Moisés), deixa claro que o material linguístico operado pelo autor permite que haja uma interação verbal com o leitor, uma vez que o universo textual foi construído a partir do "conhecimento de mundo"294, comum ao autor do texto e aos seus ouvintes/leitores ${ }^{295}$. A continuidade de sentido pela reativação do conhecimento de mundo armazenado

\footnotetext{
${ }^{293}$ Segundo Wengst "Ressuscita e vivifica os mortos" é uma fórmula judaica (cf. 1 Sm 2,6). WENGST, K., Il Vangelo di Giovanni, Brescia: Queriniana, 2005, p. 214.

${ }^{294}$ Conhecimento de mundo é o enciclopédico. Adquire-se esse conhecimento à medida que se vive tomando contato com o mundo que nos cerca e experienciando uma série de fatos. Esse conhecimento não é arquivado na memória de maneira caótica, mas em blocos cognitivos tais como: os esquemas (conjunto de conhecimentos arquivados em sequência temporal ou causal: A saída do Egito, a conquista da terra), os frames (conhecimentos armazenados na memória sob um rótulo sem que haja qualquer ordenação entre eles: o exílio, o êxodo), os scripts (conjunto de conhecimentos sobre modos de agir altamente esteriotipados em dada cultura, inclusive em termos de linguagem: rituais religiosos, fórmulas de envio, práxis jurídicas), as superestruturas ou esquemas textuais (conjunto de conhecimentos sobre os diversos tipos de textos: gêneros literários, paralelismos, quiasmos, inclusões). As palavras do texto vão ativar tal esquema que será posto em funcionamento para permitir a compreensão. Cf. KOCH, I. V.; TRAVAGLIA, L. C., A coerência textual, p. 75.

${ }^{295}$ A continuidade de sentidos depende dos processos cognitivos que operam entre si os usuários (produtor e receptor) do texto e não só de tipo lógico, mas também dependem de fatores socioculturais diversos e de fatores interpesssoais. Essa continuidade diz respeito ao modo como os componentes do mundo textual, ou seja, o conjunto dos conceitos e relações subjacentes à superfície linguística do texto são, mutuamente, acessíveis e relevantes, influindo umas na construção das outras, e se entremeando em sua expressão pela linguagem. A continuidade dos conhecimentos ativados pelas expressões linguísticas, "tópico discursivo" estabelece uma coesão conceitual cognitiva através de processos cognitivos. Cf. Ibid., p. 26.
} 
na memória do leitor/ouvinte exerce um papel decisivo para o estabelecimento da coerência desse texto.

A constatação da existência e da importância do "conhecimento partilhado" para o cálculo da construção da coerência é indispensável para a interlocução com os receptores, e isso está demonstrado nesse texto ${ }^{296}$. As proposições indicadas a seguir mostram haver entre o autor e o receptor do texto uma boa parcela de conhecimentos comuns entre os quais se destacam: a) as intenções comunicativas dos participantes da ocorrência comunicativa de que o texto é o instrumento (acusação $\mathrm{x}$ resposta); b) a função de cada um dos interlocutores: falante $\mathrm{x}$ ouvinte; c) as regras de convivência sócio-cultural-religiosa: Pai/filho - "Quem não honra o Pai...” (v. 23), “o testemunho de si mesmo não é válido" (v. 31a), "receber glória (v. 44; cf. 2 Cor 10-17), "perscrutar as Escrituras" (v. 39a; cf. 2 Cor 3,14s); d) o conteúdo semântico dos argumentos: "O Pai levanta os mortos e os faz viver..." (v. 21a) ${ }^{297}$, "O Pai tem a vida em si mesmo" (v. 26a), "Deu autoridade de fazer..." (v. 27a), "Vem a hora em que os que jazem nos sepulcros ouvirão a sua voz" (v. 28c), "Os que tiverem feito o mal"... (v. 29b), "Os que tiverem feito o bem..." (v. 29c), "Filho do Homem" (v. 27b), "julgamento justo" (v. 30c), "dar testemunho de si mesmo" (v. 31a), "vós enviastes emissários a João" (v. 33a), "a lâmpada acesa" (v. 35a), "exultar de alegria com sua luz" (v. 35c), "fazer as obras" (v. 36b), "nunca ouvistes sua voz" (v. 37c), "nem contemplastes sua face" (v. 37d), " perscrutais as Escrituras" (v. 39a), "receber glória" (vv. 41; 44b), "vir em nome de" (v. 43a), "a glória que vem do Deus único" (v. 44c), "vosso acusador" (v. 45c); e) as formas de influência do falante na situação de fala: "Eu vos digo...” (vv. 19c; 42a; 25a); "Eu sei ...” (v. 32b); "Mas eu vos conheço..." (v. 42a).

\footnotetext{
${ }^{296}$ Os elementos textuais que remetem ao conhecimento partilhado entre os interlocutores constituem a informação velha ou dada, ao passo que tudo aquilo que for introduzido a partir dela constituirá uma informação nova trazida pelo texto. Cada pessoa armazena conhecimentos na memória a partir de suas experiências pessoais; é impossível que duas pessoas partilhem o mesmo conhecimento de mundo. Para que um texto seja coerente é preciso haver um equilíbrio entre informação dada e informação nova. Consideram-se entidades conhecidas ou dadas aquelas que: a) constituem o cotexto, isto é, são recuperáveis a partir do próprio texto; b) fazem parte do contexto situacional, isto é, da situação em que se realiza o ato de comunicação ; c) são de conhecimento geral de determinada cultura; as que remetem ao conhecimento comum do produtor e do receptor. Cf. Ibid., p. 77.

${ }^{297}$ Remete a 1 Sm 2,6. Ver também Paulo em Rm 4,17.
} 
A densidade do texto exige a existência de estratégias cognitivas como as "inferências" ${ }^{298}$, que permitem ao ouvinte/leitor, utilizando seu conhecimento de mundo, estabelecer uma relação não explícita entre dois elementos ou entre segmentos do texto, a fim de compreendê-lo e/ou interpretá-lo. Eis algumas dessas inferências: a) partindo da informação veiculada pelo texto "O Filho, por si mesmo nada pode fazer" (v. 19d) e levando em conta o contexto, a inferência "mas só aquilo que vê o Pai fazer" (v. 19e) estabelece uma ponte entre a informação explícita do v. 19d e a que só será explicitada (aquilo) depois que se conhece a sequência do texto; b) no v. $27 \mathrm{~b}$ a inferência "porque é Filho do Homem" (v. 27b) reativa novas representações mentais, trazendo, ao mesmo tempo, para a superfície do texto, a alusão à escatologia judaica - a qual se referia a um acontecimento escatológico -, e ao acontecimento da paixão e morte de Jesus. Isto permitirá ao receptor atingir os diversos níveis de implícito da sequência dos vv. 25a-27a, se quiser alcançar uma compreensão mais profunda do texto que lê ou ouve; c) a inferência dos versículos 35a, 35b, 35c que traz à tona o fragmento: "Ele era a lâmpada acesa e a brilhar, vós quisestes exultar de alegria, por um momento, com sua luz" ${ }^{299}$, remete a uma experiência do ouvinte/leitor, levando-o a ser, também ele, testemunha do que está sendo afirmado; d) a inferência retroativa e exofórica a 5,18, e a endofórica da pessoa de Moisés (vv. 45c e 46a), têm a intenção de interferir na atitude do leitor diante da situação apresentada no texto, recuperando na memória o v. 18 do texto anterior: enquanto lá os acusadores de Jesus são os judeus, aqui o "acusador" dos acusadores de Jesus é Moisés. As inferências permitem a argumentatividade do texto numa continuidade de sentidos.

Uma das estratégias do autor é pressupor sempre determinados conhecimentos contextuais, situacionais, ou enciclopédicos por parte do interlocutor, os quais podem ser listados como "fatores de contextualização". Eis alguns: a) a localização do texto 5,19-47 no capítulo quinto constitui-se em um dos fatores fundamentais de contextualização. A temática desenvolvida é originada de uma situação comunicativa do texto precedente $(5,1-18)$; b) a forma

\footnotetext{
${ }^{298}$ É a operação pela qual, utilizando seu conhecimento de mundo, o receptor (leitor/ouvinte) de um texto estabelece uma relação não explícita entre dois elementos (normalmente frases ou trechos) deste texto que ele busca compreender e interpretar ou, entre segmentos de texto e os conhecimentos para sua compreensão. Cf. KOCH, I. V., Desvendando os segredos do texto, p. 50.

${ }^{299}$ O Evangelho de João em vários momentos se reporta à relação de João Batista com a luz e o testemunho: 1,7-8. 19s; 10,41. Também relaciona Jesus com os temas luz e testemunho: 8,12-14; 9,5.
} 
literária discursiva traz informações sobre o tipo de texto, permitindo ver sobre o que o texto fala quanto ao conteúdo ou sobre o próprio assunto; c) o início do texto (v. 19) ajuda a situá-lo no contexto, a avançar expectativas sobre o conteúdo, além de permitir formular hipótese sobre o conteúdo do texto, que pode se confirmar ou não; d) a disposição do capítulo 5 no Evangelho também é outro fator de contextualização, porque ajuda a ancorar o texto em uma situação comunicativa determinada: O capítulo quinto está inserido entre a narrativa do "dom da vida", concedido por Jesus ao filho moribundo do funcionário real (4,4654), e o dom da vida eterna dada pelo "pão vivo descido do céu" (6,1-71). Em ambas as seções, a revelação de Jesus vai se desenvolvendo por palavras e por sinais $(4,50 ; 6,48)$. Aqui, no capítulo 5, está explicitamente revelado o mistério do agir da "Palavra de Jesus" que dá vida como "obra de Deus" (v. 32): No Filho enviado, o Pai trabalha "até agora", realizando sua grande obra de amor pelo mundo $(5,17$; cf. 3,16$)$. E no conjunto do Evangelho é o texto fundamental no desenvolvimento da cristologia da filiação, uma vez que expressa uma intensa personalização cristológica. A coerência do texto com o Evangelho é total.

O papel da situação ${ }^{300}$ de produção na construção do sentido dos enunciados pode ser visto atuando em duas direções: a) da situação para o texto (contexto imediato) e b) do texto para a situação.

a) da situação para o texto: o lugar é Jerusalém (primeiro cenário); o momento da comunicação: uma festa dos judeus $(5,1)$; c); data: um sábado; a cena da cura: à beira de uma piscina, junto à qual uma multidão de enfermos, cegos, coxos e aleijados aguardava uma cura pela água $(5,3)$; personagens: Jesus e o paralítico. Novo cenário no qual acontece a cena do diálogo: o Templo; os interlocutores (em três momentos distintos): o homem curado e os judeus (5,1011 ); Jesus e o homem curado $(5,14)$; Jesus e os judeus os quais o acusavam de ter violado o sábado $(5,16)$. O modo como o texto de Jo 5,1-18 é narrado, bem como as imagens recíprocas que os interlocutores fazem uns dos outros, seus pontos de vista, o objetivo da comunicação, enfim todos os dados situacionais vão influir tanto na produção do texto de 5,19-47 quanto na sua compreensão.

\footnotetext{
300 A situação deve ser aqui entendida quer em sentido estrito - a situação comunicativa propriamente dita, isto é, o contexto imediato da interação - quer em sentido amplo, ou seja, o contexto sócio-religioso-cultural em que a interação está inserida. Sabe-se que a situação comunicativa interfere diretamente na maneira como o texto é construído, sendo responsável, portanto, pelas variações linguísticas. Há sempre uma mediação entre o mundo real e o mundo textual. Cf. KOCH, I. V.; TRAVAGLIA, L. C., A coerência textual, p. 85.
} 
b) Do texto para a situação: o texto de Jo 5,19-47 tem reflexos importantes sobre a situação comunicativa: o autor procura adequar o texto de acordo com determinadas intenções. A relação de referência textual exofórica com 5,17 é construída no interior do texto: "O Filho, por si mesmo, nada pode fazer" (v. 19d). É a partir dessa perspectiva que o autor vai determinar a recriação do discurso (seu mundo textual) de acordo com seus propósitos, convicções e crenças. O receptor, por sua vez, que é ouvinte da afirmação de Jesus: "Meu Pai trabalha até agora, e eu também trabalho" $(5,17)$, realiza seu ato de leitura como parceiro da comunicação, interpretando o texto de acordo com sua ótica, os seus propósitos, as suas convicções. Ao autor cabe esperar que os argumentos apresentados tenham propiciado uma situação que favoreça a comunicação prevista, porquanto encerra seu discurso, acreditando nessa possibilidade com uma oração condicional: "Se crêsseis..." (vv. 46a- 47b). Estes elementos situacionais interferem de modo determinante na produção/recepção do texto e, portanto, no estabelecimento de sua coerência.

O autor utilizou-se de diversas estratégias literárias para garantir o alto grau de informatividade ${ }^{301}$, mantendo sempre a coerência. $O$ texto distribui sua comunicação em arranjos que se alternam, ora com esse grau de informatividade, ora com a informatividade em baixa. O início do texto (v. 19d) causa surpresa pelo alto grau de informatividade. Porém, no desdobramento da sequência, a comunicação vai se estabilizando passo a passo (vv. 20-23), até ocorrer outra inesperada comunicação (v. 24). A seguir, e na linguagem metafórica, mais um pico informativo (v. 25) com nova estabilização (vv. 28-29). Ao se prosseguir na leitura constata-se mais um grande salto informativo: o falante assume, de modo surpreendente, a identidade do "Filho" (v. 30b). Tendo alcançado tão alto grau de informatividade, daí em diante, na comunicação da sequência dos versículos 3147, acontece uma desaceleração do ritmo, como se o autor pretendesse dar um tempo maior para o processamento do que foi dito, com acréscimos de argumentos, a fim de facilitar a compreensão e adesão do ouvinte/leitor.

\footnotetext{
${ }^{301}$ A informatividade diz respeito ao grau de previsibilidade ou expectabilidade da informação contida no texto. Se for previsível, será menos informativo. É a informatividade que vai determinar a seleção e o arranjo das alternativas de distribuição da informação no texto, de modo que o receptor possa calcular-lhe o sentido com maior ou menor facilidade. Cf. Ibid., p. 86.
} 
Outra estratégia para garantir a coerência, bastante utilizada, foi a focalização $^{302}$. O texto está organizado para conduzir o leitor/ouvinte à aceitação da verdade sobre a relação filial de Jesus com Deus (cf. 5,17); portanto, àquela situação específica que é a relação Filho - Pai. A introdução do texto (v. 19d) tem papel preponderante nessa focalização, porque condensa o conteúdo a ser exposto no texto. Na sequência do texto, esse conteúdo é estrategicamente desenvolvido, buscando a continuidade de sentido em torno da proposição inicial, por meio do uso selecionado de itens lexicais, poucos e recorrentes, como os sintagmas nominais o’ pathr e o’ uiòj, de um excessivo uso de certos elementos linguísticos referenciais, como os pronomes pessoais e os advérbios, de grupos verbais pertencentes a um mesmo campo semântico e de expressões definidas. Todos estes recursos linguísticos e semânticos, ativando conhecimentos de mundo arquivados na memória, avançando expectativas sobre o conteúdo da relação Filho - Pai são meios de evidenciar a focalização e, portanto, construir a coerência temática.

O recurso à intertextualidade é muito marcante no texto. $\mathrm{O}$ discurso de João 5,19-47 foi construído através de um-já-dito $(5,17)$ em relação ao qual o autor tomou uma posição (v. 19a). Assim, o processo discursivo, de direito, não tem um início: o discurso se estabelece sobre um discurso prévio $(5,16-18)$. Na sequência do texto se verifica que as operações produtoras de sentido são sempre intertextuais (a relação Pai - Filho; a escuta e a crença na Palavra do enviado; o julgamento divino; a necessidade de testemunho do representante qualificado daquele que o enviou, as Escrituras e sua relação com Moisés). Há uma relação de intertextualidade com outros discursos relativamente autônomos do próprio Evangelho (o Prólogo 1,18; os capítulos: 3,16-18. 27-28. 35-36; 7,21-23; 8,14-19; 8,26-29. 40. 42.47; 10,10. 25. 32-38; 11,25; e especialmente o capítulo 14 etc.). Além destes, o autor recorre ao conhecimento prévio de outros textos narrativos dos Evangelhos Sinóticos, como o repouso sabático, as seções sobre João Batista, os testemunhos, o julgamento e o Filho do Homem, e a outros textos - do Novo Testamento (cf. Mt 11,26; Lc 10,22; Mc 2,6-12), bem como do Antigo Testamento (cf. vv. 28b-29c com o texto de Dn 12,2; os vv. 44-47 com Ex 33,18-

\footnotetext{
${ }^{302}$ Seria com uma câmara que acompanhasse tanto o autor como o receptor no momento em que o texto é processado. Diferenças de focalização podem causar problemas sérios de compreensão, impedindo, por vezes, o estabelecimento da coerência. Verifica-se que a focalização tem relação direta com a questão do conhecimento de mundo, e de conhecimento compartilhado. Cf. Ibid., p. 88.
} 
20 - Moisés não pode ver a glória, a face de Deus; o v. 43a com Ex 33,19 - o nome de YHWH; Ex 34,29: as tábuas do testemunho - equivalentes às Escrituras - que fazem parte de um repertório selecionado). O texto faz uso ainda de fragmentos de textos do próprio Evangelho, como se fosse um mosaico de citações absorvidas e transformadas: O Pai ama o Filho; obras maiores; honrar o Pai; quem escuta minha palavra; tem a vida eterna; autoridade de fazer o julgamento; dar testemunho etc. A análise dos aspectos léxicos (cf. item 4.2.1) constatou uma familiaridade dos itens lexicais com outros textos bíblicos e com as formas de expressões literárias: paráfrases, paralelismos, quiasmos, inclusões etc.

O autor, ao organizar sua própria estratégia textual, referiu-se a uma série de competências - que devem ser também as competências do leitor implícito ${ }^{303}$ conferindo conteúdo às expressões, usadas de forma a manifestar sua intencionalidade $^{304}$. Os meios utilizados são muitos: o tipo de texto, as marcas linguísticas ${ }^{305}$ que orientam os seus enunciados no sentido de determinadas conclusões, a escolha do patrimônio lexical, os operadores e conectores argumentativos, as inferências. A estratégia da objetivação do assunto, na qual o autor apresenta (vv. 19f-23e; 25a-29c) seus argumentos em terceira pessoa, é uma maneira de abordar o assunto com certo distanciamento. Pelo alto índice de argumentatividade subjacente, não somente no uso da linguagem, mas também na distribuição do texto, pode-se admitir a intenção do autor, seu mundo textual.

No ato de leitura do texto 5,19-47, a relação de interação entre cada um dos parceiros (texto-leitor) é ressaltada, deixando perceber que a própria organização textual contribui para produzir essa cooperação; é o que se chama de fator de aceitabilidade $^{306}$. Assim, por exemplo, no enunciado que abre o discurso: "o

\footnotetext{
${ }^{303} \mathrm{O}$ texto não apenas repousa numa competência, mas também contribui para produzi-la. Cf. ECO, U., Lector in fabula, São Paulo: Perspectiva, 2011, p. 40.

${ }^{304} \mathrm{~A}$ intencionalidade constitui-se no esforço que o autor realiza para fazer-se compreendido. A intencionalidade refere-se ao modo como os emissores usam textos para perseguir e realizar suas intenções, produzindo textos adequados à obtenção dos efeitos desejados. A intencionalidade tem relação estreita com o que se tem chamado de argumentatividade. Pela argumentatividade subjacente ao uso da linguagem pode-se admitir a intenção do autor. Ela se manifesta nos textos através de pistas ou de uma série de marcas que vão orientar os seus enunciados no sentido de determinadas conclusões, isto é vão determinar-lhes a orientação argumentativa segundo uma perspectiva dada. Entre essas marcas encontram-se os tempos verbais, os operadores e conectores argumentativos (aliás, até, enfim, mesmo, como, mas) os modalizadores das inferências. Cf. KOCH, I. V.; TRAVAGLIA, L. C., A coerência textual, p. 97.

305 Entre essas marcas encontram-se os tempos verbais (78 verbos no modo indicativo) e os pronomes que desempenham a função de reativação de referentes (86 pronomes),

${ }^{306} \mathrm{O}$ texto é organizado de forma que seja apropriado pelo leitor. Quem produziu a sequência tem a intenção de que ela seja um texto e pretende realizar com ela uma intenção comunicativa. Há um
} 
Filho, por si mesmo, nada pode fazer”, há uma pretensão de que esta declaração desencadeie no receptor a lembrança da polêmica declaração de Jesus do texto imediatamente anterior $(5,17)$, que resultou em uma dupla acusação: Jesus é acusado de, além de violar o sábado, dizer que Deus é seu Pai, fazendo-se, assim, igual a Deus $(5,18)$. Este elemento de contextualização lhe permitirá agir cooperativamente, procurando determinar-lhe o sentido. Ao construir a sua leitura ele vai, de imediato, diferençar seus vários passos, possibilitados pelo próprio texto, e apreender sua construção hierárquica entre as marcas linguísticas, as inferências, argumentos, e demais elementos construtores da textualidade que o texto, pela maneira como se encontra linguisticamente estruturado, permite.

A consistência e a relevância de um texto acontecem quando não se observa nenhum argumento contraditório entre os enunciados do mesmo texto. Não havendo contradição entre eles, pode-se afirmar que todos são verdadeiros, e, portanto, o texto apresenta muita consistência em seus enunciados. A asseveração inicial de Jesus: "O Filho, por si mesmo, nada pode fazer" (v. 19d) dá consistência ao texto porque, em cada sequência, o autor desenvolve em seus enunciados motivos que visam elucidar e aprofundar esta proposição assertiva. O conjunto dos enunciados que compõem o texto é relevante para um mesmo tópico discursivo subjacente, isto é, os enunciados são interpretáveis como falando sobre um mesmo tema, e este é um dos principais requisitos exigido pela relevância.

A análise dos múltiplos fatores de coerência textual do discurso de Jo 5,1947, considerado dentro do conjunto do diálogo, constatou haver entre texto e usuários uma relação de situação comunicativa que the assegura a continuidade de sentidos, e, portanto, uma unidade no todo do texto, concluindo-se por sua coerência textual. O autor amarrou as informações, de modo a permitir que os leitores extraiam delas um conhecimento real e conclusões relativamente seguras, "soldando" as peças de forma coerente, combinando adequadamente "as pedras do mosaico". Está em perfeita harmonia com o pensamento desenvolvido em todo o discurso. A temática Pai/Filho reaparece em outras partes do Evangelho e tem

plano de pressupostos para a produção do texto que inclui, além das possibilidades que o próprio texto fornece, as condições sócio-históricas mediadoras das diversas formações de sentido que poderão ser realizadas pelos leitores na recepção do texto. Cada comunicação enunciada, ao utilizar elementos afins do mundo textual do receptor, vai ativar o conhecimento de mundo arquivado em sua memória, trazendo à tona conhecimentos que vão fazer com que ele procure, não só determinar-lhe o sentido, mas até recuperar as diversidades das reações por ela provocadas. Cf. ECO, U., op. cit., p. 40. 
coerência com outros aspectos deste tema tratado por João: o amor do Pai pelo Filho $(3,16)$, o envio do Filho $(3,17)$, a revelação do Pai no Filho $(14,9)$ etc.

\subsection{2. \\ A coerência pragmática}

A coerência pragmática tem a ver com o texto, visto como uma sequência de atos de fala. Estes são relacionados de modo que, para a sequência de atos ser percebida como apropriada, os atos de fala que a constituem devem satisfazer as mesmas condições presentes em uma dada situação comunicativa ${ }^{307}$. Esse texto só será coerente, ou seja, só fará sentido, se considerados os atos de fala que cada enunciado realiza. Portanto, a relação a ser estabelecida pode ser não somente semântica (entre conteúdos), mas também pragmática, entre atos de fala ${ }^{308}$.

A situação comunicativa ativada pela expressão "O Pai trabalha até agora, e eu também trabalho" $(5,17)$ motivou não só a reação dos judeus $(5,18)$, mas também uma contrarreação de Jesus à interpelação daqueles (5,16 e 18). No contexto do discurso ${ }^{309}$, condiciona o evento semântico, estabelecendo uma relação com algum tipo de informação presente na memória discursiva de seus interlocutores $^{310}$. Tem-se, portanto, em apekri nato ouf o 'Vhsai' uma referência anafórica relativa ao conteúdo desses versículos, cujo contexto deu origem à necessidade de Jesus apresentar sua justificativa.

\footnotetext{
${ }^{307}$ Cf. KOCH, I. V.; TRAVAGLIA, L. C., A coerência textual, p. 45.

${ }^{308}$ A coerência seria entre os atos de fala que as proposições realizam. Uma proposição é definida como a representação linguística de um estado de coisas por meio de um ato de referência ou predicação; daí a expressão "conteúdo proposicional". Cf. Ibid., p. 61.

${ }^{309} \mathrm{O}$ contexto do qual dependem as frases é o mesmo que serve para analisar os atos de fala. Cf. ARMENGAUD, F., A pragmática, São Paulo: Parábola, 2006, p. 82.

${ }^{310} \mathrm{Na}$ constituição da memória discursiva, estão envolvidas, como operações básicas, as seguintes estratégias de referenciação: 1. Construção/ativação: a expressão linguística que o representa é posta em foco na memória de trabalho, de tal forma que o "objeto" textual, até então não introduzido, passa a preencher um nódulo na rede conceitual do modelo de mundo textual, de tal forma que esse objeto fica saliente no modelo; 2 . Reconstrução/reativação: um nódulo já presente na memória discursiva é reintroduzido na memória operacional, por meio de uma forma referencial, de modo que o objeto-de-discurso permanece saliente; 3. Desfocalização/desativação: ocorre quando um novo objeto-de-discurso é introduzido, passando a ocupar a posição focal. O objeto retirado de foco, contudo, permance em estado de ativação parcial, podendo voltar à posição focal a qualquer momento, ou seja, ele continua disponível para utilização imediata na memória dos interlocutores. Cf. KOCH, I. V., Introdução à linguística textual, p. 62.
} 


\begin{tabular}{|c|c|c|}
\hline $19 \mathrm{a}$ & 'Apekri nato ouf o 'Whai' & Respondeu, pois, Jesus \\
\hline $19 \mathrm{~b}$ & kai . el egen autroi $\lambda$ & e disse-lhes: \\
\hline $19 \mathrm{c}$ & anhn andinn l egw uñnht & "amém, amém, digo-vos: \\
\hline $19 \mathrm{~d}$ & oudunatai o uioj poi éh af/Veautou/ouden & o Filho, por si mesmo, nada pode fazer, \\
\hline $19 \mathrm{e}$ & ean nh, ti d eph|ton patera poi ountal & senão aquilo que vê o Pai fazer; \\
\hline $19 \mathrm{f}$ & a]gar ah dkeinoj poin & portanto, tudo que Ele faz, \\
\hline $19 \mathrm{~g}$ & tauka kai . o uioj ondi my poi él & $\begin{array}{l}\text { isto também o Filho da mesma forma } \\
\text { faz. }\end{array}$ \\
\hline
\end{tabular}

O discurso se inicia com um ato de fala assertivo: "Respondeu". É evidente o aspecto ilocutório da forma verbal performativa apekrinato que toma a iniciativa da reação (v. 19a) ${ }^{311}$. A situação de fala está duplamente demonstrada: na apresentação do falante (v. 19a) e na solene introdução anhn anhn l egw ừnhh (v. 19c). Este anłnn anhn típico do Jesus joanino é um ato linguístico que compromete o falante com a verdade da proposição ${ }^{312}$. Por ele Jesus reclama a autoridade da verdade divina ${ }^{313}$. É também um ato de fala assertivo em primeira pessoa: "digo-vos" (l egw ùninh), que inicia o que vai ser dito em terceira pessoa:

"O Filho por si mesmo nada pode fazer, senão aquilo que vê o Pai fazendo; porque tudo que Ele faz, o Filho igualmente faz" (vv. 19d-e-f-g). O que o falante aí assevera será esclarecido na sequência dos versículos 20a-23e nos quais se encadeiam atos de fala com função discursivo-justificativa, articulados pelas conjunções: gar, iha, wșper, aMl a, oufwj, kai, kaquj.

\begin{tabular}{|c|c|c|}
\hline $20 \mathrm{a}$ & o'gar pathr fil é/ton uiòn & O Pai, portanto, ama o Filho \\
\hline $20 \mathrm{~b}$ & kai . panta deiknusi n autw" & e lhe mostra tudo \\
\hline $20 \mathrm{c}$ & a]autroj poi $\dot{\theta} \ell$ & o que Ele faz; \\
\hline $20 \mathrm{~d}$ & kai . neizona toutwn de xé autw/ergal & e lhe mostrará obras maiores do que estas \\
\hline $20 \mathrm{e}$ & i ha uñej' qaunazhte & para que vós vos admireis. \\
\hline $21 \mathrm{a}$ & WÉper gar o pathr egere touj nekrouj & Como o Pai levanta os mortos \\
\hline $21 \mathrm{~b}$ & kai .zuppoi बi & e faz viver, \\
\hline $21 \mathrm{c}$ & oufwj kai.o uiòj zwppoi $\dot{\theta} /$ & assim também o Filho faz viver \\
\hline $21 \mathrm{~d}$ & oul qबi & Aqueles que quer. \\
\hline $22 \mathrm{a}$ & oude gar o pathr kri né oudenal & Pois o Pai a ninguém julga, \\
\hline $22 \mathrm{~b}$ & aMl a. thn krișin pasan dephken tw/ui wh & mas deu ao Filho todo julgamento, \\
\hline $23 \mathrm{a}$ & ina pantej ti nowi ton uión & a fim de que todos honrem o Filho, \\
\hline $23 \mathrm{~b}$ & kaquy ti nowsi ton paterar & assim como honram o Pai. \\
\hline
\end{tabular}

311 A forma verbal apekrinato no indicativo aoristo $1^{\mathrm{o}}$ médio, $3^{\mathrm{a}}$ pessoa do singular, ao invés do ordinário médio-passivo apekri gh é muito pouco usada. Aqui dá importância à réplica de Jesus. No Evangelho de João aparece, exclusivamente, no capítulo 5, nos versículos 17 e 19. Segundo M. Zerwick este uso parece confirmar a observação de Moulton-Millings de que a forma verbal apokri nasqai era especialmente solene no uso helenístico. É encontrado apenas 4 vezes nos evangelhos sinóticos, sendo três vezes em passagens não paralelas (Mt 27,12; Mc 14,61; Lc 23,9) e Lc 3,16. Nas outras passagens é usado o aoristo ordinário médio-passivo apekri gh (195 vezes no NT, inclusive em Jo 5,7. 11). Cf. ZERWICK, M., Biblical Greek, p. 74.

312 ARMENGAUD, F., A pragmática, p. 111.

${ }^{313}$ Cf. HÜBNER, H. O., verbete alkhqe a In BALZ, H.; SCHNEIDER, G., DENT, p. 175. 


\begin{tabular}{|l|l|l|}
\hline $23 \mathrm{c}$ & O nnh. ti nowh ton uiờn & Quem não honra o Filho \\
\hline $23 \mathrm{~d}$ & ounti na/ton patera & não honra o Pai \\
\hline $23 \mathrm{e}$ & ton penyanta autón & que o enviou. \\
\hline
\end{tabular}

Essa sequência de proposições, nas quais se podem notar fórmulas prontas (o que Ele faz, obras maiores, levanta os mortos, faz viver, a ninguém julga, todo $o$ julgamento), desempenha um papel importante na ativação do esquema cognitivo que será posto em funcionamento para permitir a compreensão do texto $^{314}$. Nesses atos de fala diretivos, o falante deseja ativar nos ouvintes conhecimentos que se referem ao fazer do Pai. Eles devem ser relevantes na compreensão da revelação da relação Pai - Filho, pois se referem à unidade de ação existente entre o Pai e o Filho, a qual inclui a vivificação, o julgamento e, consequentemente, a mesma honra que se deve ao Pai. Assim, nos versículos 19d23 e "a situação comunicativa" do ato linguístico ilocutório da resposta de Jesus (19a) insiste em que os interlocutores aceitem a identidade que há entre o Filho e o Pai, mediante as obras de dar vida e fazer julgamento confiadas ao Filho pelo Pai.

Novo ato de fala (v. 24a) realiza uma segunda asseveração: “Amém, amém, Digo-vos":

\begin{tabular}{|c|c|c|}
\hline $24 \mathrm{a}$ & Anthn anthn l egw uñinh & Amém, amém, digo-vos: \\
\hline $24 \mathrm{~b}$ & ofi o ton l ogon nou akoumn & quem escuta a minha palavra \\
\hline $24 \mathrm{c}$ & kai. pi steumn & e crê \\
\hline $24 \mathrm{~d}$ & tw/penyanti , ne & naquele que me enviou \\
\hline $24 \mathrm{e}$ & ece $z w h$ ai wni on & tem vida eterna, \\
\hline $24 \mathrm{f}$ & kai.ejk krisin alk ercetai ( & e não vem a julgamento, \\
\hline $24 \mathrm{~g}$ & aM a. netabedken ed toul qanatou ej j thn zwhn & mas passou da morte à vida. \\
\hline
\end{tabular}

No versículo $24 \mathrm{~b}$ uma nova enunciação, expressa positivamente, e com novo sujeito falante, agora em primeira pessoa do singular, sublinha o caráter revelador da "palavra" do Enviado. Essa asseveração, ampliando a que foi proferida anteriormente, assinala a novidade da íntima relação que existe entre a palavra do "Enviado" e a de "Quem" o enviou. O falante, agora, realiza um ato de fala comissivo, prometendo algo futuro a quem acolher sua proposição: "Quem escuta a minha palavra e crê naquele que me enviou tem vida eterna, e não vem a julgamento, mas passou da morte à vida”. $\mathrm{O}$ ato de fala iniciado com a conjunção ofi (v. 24b) solicita ao ouvinte/leitor uma abertura para escutar o que o enviado

${ }^{314}$ Cf. KOCH, I. V., Introdução à linguística textual, p. 72. 
tem a dizer, e conclui (vv. 24f-24g) com uma promessa para quem acreditar no que foi asseverado: "Tem vida eterna e não vem a julgamento". A situação comunicativa já apresenta sinais de melhoria, uma vez que o falante tem esperança de que possa não só ser ouvido, como também ser crido.

A continuidade de sentidos, na sequência seguinte, versículos 25b-30e, se dá por um novo ato de fala, iniciando-se com mais uma asseveração (v. 25a) que vem também iniciada pela mesma expressão anhn anhn l egw ù̀mh em primeira pessoa, e insiste no aspecto revelador do que vai ser dito.

\begin{tabular}{|c|c|c|}
\hline $25 \mathrm{a}$ & anhnn anhn l egw uñ̀n & Amém, amém, digo-vos: \\
\hline $25 b$ & ofti ercetai wra & vem a hora \\
\hline $25 \mathrm{c}$ & kai . nuh estin & e é agora \\
\hline $25 \mathrm{~d}$ & $\begin{array}{l}\text { ofe oi nekroi . alkousousin th' f whi' toul } \\
\text { ui oultoul qear }\end{array}$ & $\begin{array}{l}\text { em que os mortos ouvirão a voz do Filho } \\
\text { de Deus, }\end{array}$ \\
\hline $25 \mathrm{e}$ & kai.oi akousanté & e os que ouvirem \\
\hline $25 \mathrm{f}$ & zhsousin & viverão. \\
\hline $26 \mathrm{a}$ & WEsper gar o pathr ecé zwhn eq éutw & Assim como o Pai tem vida em si mesmo, \\
\hline $26 \mathrm{~b}$ & $\begin{array}{l}\text { atwi kai . tw/ ui w/ edMken zwhn ecén en } \\
\text { eautwA }\end{array}$ & $\begin{array}{l}\text { Assim também concedeu ao Filho ter vida } \\
\text { em si mesmo, }\end{array}$ \\
\hline $27 \mathrm{a}$ & kai . exousi an edkken autm/krisin poi éh & e lhe deu autoridade de fazer julgamento, \\
\hline $27 \mathrm{~b}$ & ofti ưö anqrupou estin & porque é Filho do Homem. \\
\hline $28 \mathrm{a}$ & nh. qaunazete toukd & Não vos admireis com isto: \\
\hline $28 \mathrm{~b}$ & ofi ercetai wra & vem a hora \\
\hline $28 \mathrm{c}$ & 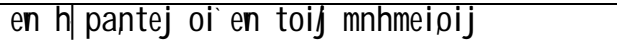 & na qual todos os que estão nos sepulcros \\
\hline $28 \mathrm{~d}$ & akousousin th' f wnh' autrou & ouvirão a sua voz \\
\hline $29 \mathrm{a}$ & kai . expor eusontai & e sairão: \\
\hline $29 \mathrm{~b}$ & $\begin{array}{l}\text { oi ta. agaca. poi hsantej ej amastasin } \\
\text { zwhil( }\end{array}$ & $\begin{array}{l}\text { os que tiverem feito o bem, para uma } \\
\text { ressurreição de vida; }\end{array}$ \\
\hline $29 \mathrm{c}$ & $\begin{array}{l}\text { oi de ta. faula praxantej ej amastasin } \\
\text { krisenj } \AA\end{array}$ & $\begin{array}{l}\text { os que tiverem praticado o mal, para uma } \\
\text { ressurreição de julgamento. }\end{array}$ \\
\hline $30 \mathrm{a}$ & $\begin{array}{l}\text { Oun dananai egw. poi eih apl exautoul } \\
\text { oudenl }\end{array}$ & Eu, por mim mesmo, nada posso fazer: \\
\hline $30 \mathrm{~b}$ & kaquj akoun kring & julgo conforme o que ouço, \\
\hline $30 \mathrm{c}$ & kai. h krișij heah. d kai a estin & e meu julgamento é justo, \\
\hline $30 \mathrm{~d}$ & ofi ounzhtw/to. qa hna to. exon & porque não procuro minha vontade, \\
\hline $30 \mathrm{e}$ & all a. to. qe hra tou penyantoj n & Mas a vontade do que me enviou. \\
\hline
\end{tabular}

Após essa terceira asseveração, com nova revelação, em terceira pessoa, o falante pronuncia um ato de fala ilocutório declarativo, o qual implica numa mudança de situação e altera o estado dos ouvintes não apenas mortos, como também dos já sepultados: "Vem a hora e é agora em que os mortos ouvirão a voz do Filho de Deus, e os que a ouvirem viverão" (v. 25) e "os que estão no sepulcro ouvirão a voz e sairão; os que tiverem praticado o mal; os que tiverem praticado o bem; ressurreição de vida/de julgamento" (vv. 28-29). Aqui, não apenas retoma as novas revelações de como ter a "vida eterna e não vir a julgamento" (v. 24), 
mostrando como as ideias escatológicas novas se entrelaçam e são mutuamente dependentes das antigas, influindo na construção de sentido umas das outras. O simples cotejo das ideias das expressões linguísticas que as ativam ( o Pai tem a vida em si mesmo, concedeu ao Filho ter a vida em si mesmo, fazer julgamento, Filho do Homem) e suas posições no texto ativam processos cognitivos operantes entre os leitores/ouvintes pelas relações entre as ideias relevantes que se ligam à sua organização superficial, linguística, embora esta dependa daquela e sirva de pista para sua determinação ${ }^{315}$.

$\mathrm{O}$ versículo $30 \mathrm{a}$ apresenta um ato de fala ilocutório assertivo que se refere à primeira asseveração: o leitor do texto deve estar querendo saber quem é este Filho (v. 19d), quem é o "enviado" (v. 24e) e "Filho do Homem" (v. 27b). A função do ato de linguagem aqui (v. 30a) é expressiva, quer apresentar a pessoa do Filho: " $\mathrm{Eu}$, (o Filho), por mim mesmo, nada posso fazer". O pronome egw, funciona como focalizador de atenção ${ }^{316}$. Ao enfatizar com o pronome pessoal egw,o que foi asseverado no v. 19d em terceira pessoa sobre o Filho, o falante se assume, ele próprio, como "o Filho".

Agora Jesus, manifestando-se como "o Filho", reivindica credibilidade em sua identidade de Filho. Postas as asseverações que garantiram a "coerência local" nos textos dos versículos $19-23 ; 24 ; 25-30$ a continuidade de sentido se faz aqui por meio da forte presença da expressão verbal negativa "nada posso fazer" (v. 19d // 30a), que cria condições para que os elementos da "comprovação" da identidade de Jesus como "o Filho" possam ser estabelecidos. Esta identidade pode ser percebida numa comparação entre as características reveladas do Filho e a atividade de Jesus. Toda a atividade de Jesus é um testemunho, uma revelação: suas palavras, suas obras, seus ensinamentos, seus gestos ${ }^{317}$. Assim, a estratégia para a "comprovação" é recorrer aos "testemunhos". Desse modo, o binômio

\footnotetext{
${ }^{315}$ A coerência é subjacente, tentacular, reticulada, não linear e se relaciona com a linearidade do texto. Cf. KOCH, I. V., O texto e a construção de sentidos, São Paulo: Contexto, 2011, p. 47.

${ }^{316}$ Segundo Koch, os dêiticos discursivos, os pronomes com função dêitica monitoram o leitor no sentido da seleção de focos de conteúdo, e são táticas discursivas que permitem cercar determinado problema por todos os possíveis ângulos e perspectivas. Cf. Ibid., p. 65.

${ }^{317}$ Os atos de fala devem satisfazer as mesmas condições presentes em uma dada situação comunicativa. Caso contrário, tem-se incoerência. Assim, se há uma sequência de "asseverações" e "declarações", seria de se esperar que tivesse uma sequência de atos que "comprovassem" as "asseverações" realizadas.
} 
linguístico asserção/comprovação (31a-39d) responde pela continuidade de sentidos.

\begin{tabular}{|c|c|c|}
\hline $31 \mathrm{a}$ & Ean egw. narturw/peri. exautouk & Se eu dou testemunho de mim mesmo, \\
\hline $31 \mathrm{~b}$ & h marturia nou ouk estin alwhiji & o meu testemunho não é verdadeiro; \\
\hline $32 \mathrm{a}$ & alloj estin o narturwh peri. exoul & outro é que testemunha sobre mim, \\
\hline $32 \mathrm{~b}$ & kai. oi ta & e sei \\
\hline $32 \mathrm{c}$ & ofi awhodi estin hinarturia & que verdadeiro é o testemunho \\
\hline $32 \mathrm{~d}$ & hih narturé/peri. enour & que testemunha sobre mim. \\
\hline $33 \mathrm{a}$ & uneil' apestal kate proj Vwannhn' & Vós enviastes (emissários) a João, \\
\hline $33 \mathrm{~b}$ & kai . nenarturhken th/akhajal & o qual deu testemunho da verdade. \\
\hline $34 \mathrm{a}$ & $\begin{array}{l}\text { egw. de oun para. augr upou thn narturian } \\
\text { I anbanw }\end{array}$ & $\begin{array}{l}\text { Eu, no entanto, não recebo testemunho } \\
\text { de um homem; }\end{array}$ \\
\hline $34 \mathrm{~b}$ & aM a. tauka legw & mas falo essas coisas \\
\hline $34 \mathrm{c}$ & ifa uneil' swohke & para que vos salveis. \\
\hline $35 \mathrm{a}$ & eke hoj ha ol ucnoj o kai onenoj & Ele era a lâmpada acesa \\
\hline $35 \mathrm{~b}$ & kai .f ai nwn( & e brilhante, \\
\hline $35 \mathrm{c}$ & $\begin{array}{l}\text { uneil' de hod hsate agal l i aqhnai proj wtan } \\
\text { en tw/f wti . autouA }\end{array}$ & $\begin{array}{l}\text { vós, porém, vos alegrastes, por algum } \\
\text { tempo, com sua luz. }\end{array}$ \\
\hline $36 \mathrm{a}$ & $\begin{array}{l}\text { Egw. de ecw thn narturian neizw toul } \\
\text { Wwannoul }\end{array}$ & $\begin{array}{l}\text { Eu, porém, tenho um testemunho } \\
\text { maior que o de João: }\end{array}$ \\
\hline $36 \mathrm{~b}$ & ta. gar erga a]dephken noi o pathr & as obras que o Pai me deu \\
\hline $36 \mathrm{c}$ & i ha te e $\mathrm{s}$ sw autal & para que as leve a termo; \\
\hline $36 \mathrm{~d}$ & auta. ta. ধ ga a]poi w/ & estas obras que faço, \\
\hline $36 \mathrm{e}$ & narturé/peri. enou & testemunham sobre mim \\
\hline $36 \mathrm{f}$ & ofti o pathr ne apestal kev & que o Pai me enviou. \\
\hline $37 \mathrm{a}$ & kai .o penyaj ne pathr & E o Pai que me enviou, \\
\hline $37 \mathrm{~b}$ & eke hoj nenarturhken peri. enowA & Ele testemunhou sobre mim. \\
\hline $37 \mathrm{c}$ & oute f wnhn autrou/pwpote alkhkoate & Nunca ouvistes a sua voz, \\
\hline $37 \mathrm{~d}$ & oute eiejoj autou/ ewrakate & nem contemplastes a sua face, \\
\hline $38 \mathrm{a}$ & $\begin{array}{l}\text { kai. ton l ogon autow ouk ecete en unimh } \\
\text { nenontal }\end{array}$ & $\begin{array}{l}\text { e não tendes sua palavra, } \\
\text { permanecendo em vós, }\end{array}$ \\
\hline $38 \mathrm{~b}$ & ofi oh apestél en dké hoj ( & porque naquele que ele enviou \\
\hline $38 \mathrm{c}$ & toutw/ uneil' oumpi stente & vós não credes. \\
\hline $39 \mathrm{a}$ & evaunate taj graf aj ( & Perscrutais as Escrituras, \\
\hline $39 \mathrm{~b}$ & $\begin{array}{l}\text { ofi uneil' doke the en autail' zwhn ai wnion } \\
\text { eceinl }\end{array}$ & Porque julgais ter nelas vida eterna; \\
\hline $39 \mathrm{c}$ & kai . eke hai, e esin ai & E são elas que \\
\hline $39 \mathrm{~d}$ & narturoubai peri.enoul & testemunham sobre mim; \\
\hline
\end{tabular}

Assim, o falante é levado a sustentar a verdade de sua proposição agora no grau comprobatório. A relevância da legitimação se confirma ao encadear atos de fala distintos, introduzindo relações discursivo-argumentativas de condicionalidade, justificativa, explicação, especificação, mediação, finalidade e contraste. Observe-se que é relevante, porque interage, de certa forma, sobre o mundo textual, em relação não somente ao discurso, mas também ao contexto; ou seja, em relação a um conjunto de proposições ou hipóteses derivadas não apenas do texto precedente $(5,1-18)$, mas também da memória, da percepção do entorno, 
enfim, de todo o contexto, por intermédio de inferências (a João Batista, à lâmpada, à face, à voz etc.).

A reação à afirmação da identidade de Jesus como Filho pode ser demonstrada pela linguagem que encena a atitude psicológica com que o falante se representa diante dos eventos de que fala (vv. 40a-47b): É um ato ilocutório expressivo $^{318}$ que pretende recorrer, mais uma vez, à adesão pessoal.

\begin{tabular}{|c|c|c|}
\hline $40 \mathrm{a}$ & kai . ounqd ete dväh proj ne & Porém, não quereis vir a mim \\
\hline $40 \mathrm{~b}$ & ina zwh echte & para que tenhais vida. \\
\hline 41 & Doxan par a. aldir wpwn oum anbanm & Glória, não recebo dos homens. \\
\hline $42 \mathrm{a}$ & aMl a. egnwka unal' & Aliás, vos conheço: \\
\hline $42 \mathrm{~b}$ & $\begin{array}{l}\text { ofi thn agaphn toul qeoul alk ecete en } \\
\text { eautoi } j \AA\end{array}$ & não tendes em vós o amor de Deus. \\
\hline $43 \mathrm{a}$ & egw. evh/ uqa en tw/ononati tou/patroj nou & Eu vim em nome de meu Pai, \\
\hline $43 \mathrm{~b}$ & kai . oum anbanete, nel & Mas não me recebeis; \\
\hline $43 \mathrm{c}$ & ean alloj eq on ea tw/anonati tw/ia m & $\begin{array}{l}\text { se um outro viesse em seu próprio } \\
\text { nome, }\end{array}$ \\
\hline $43 \mathrm{~d}$ & dxei hon I hyyesqe & vós o receberíeis. \\
\hline $44 \mathrm{a}$ & pw' dunasqe unieil' pi steúai & Como podereis crer \\
\hline $44 \mathrm{~b}$ & doxan para. all hI wn I anbanontej( & vós que recebeis glória um dos outros, \\
\hline $44 \mathrm{c}$ & $\begin{array}{l}\text { kai. thn doxan thn para. tour nonou qeoul oun } \\
\text { zhte } t \in E\end{array}$ & $\begin{array}{l}\text { e não procurais a glória que vem do } \\
\text { Deus único? }\end{array}$ \\
\hline $45 \mathrm{a}$ & nh. dokéte & Não julgueis \\
\hline $45 \mathrm{~b}$ & ofi egw. kathgorhsw inowh proj ton pateral & que eu vos acusarei diante do Pai: \\
\hline $45 \mathrm{c}$ & estin o kathgor wh iñwh MmBhy'( & É Moisés o vosso acusador, \\
\hline $45 \mathrm{~d}$ & ejv oh unei h hpikate & no qual pusestes vossa esperança. \\
\hline $46 \mathrm{a}$ & 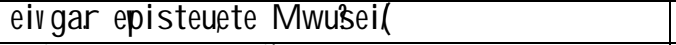 & Se, pois, crêsseis em Moisés, \\
\hline $46 \mathrm{~b}$ & eqisteute ah exoil & creríeis em mim; \\
\hline $46 \mathrm{c}$ & peri.gar enou/ dké hoj egrayen & pois a meu respeito ele escreveu. \\
\hline $47 \mathrm{a}$ & e vde toil d ede nou gramasi n oumpi stente & mas se não acreditais em seus escritos, \\
\hline $47 \mathrm{~b}$ & pw' toi /' exoij/ rhnasi in pisteused & como crereis em minhas palavras? \\
\hline
\end{tabular}

Examinando-se as ações linguísticas - os atos de palavra: não recebo, aliás vos conheço, não tendes, mas não me recebeis, se um outro... vós..., como ... como - , vê-se que o contexto e as situações de palavra nas quais são colocados os elementos de coesão, visam a uma interação face a face, com o objetivo de detectar as pressuposições em que se devem basear o autor para manter o

\footnotetext{
${ }^{318}$ A mensagem centrada no falante sugere uma atitude emocional que expressa sentimentos de que não há vontade nos ouvintes em acolher o que ele quer comunicar. Conforme a análise dos aspectos sintáticos (cf. 4.2.2), os elementos expressivos da mensagem são (subordinada condicional v. 43c); o advérbio pw' (v. 44a); a partícula negativa $\mathrm{nh}$, que inicia o v. 45a, cuja função é manifestar a simples intenção de quem fala. A conjunção subordinativa integrante đđi no v. 45b depois da forma verbal dokẻłe indica percepção, através da mente, da situação dada. Nova oração condicional (v. 46a) aqui com a conjunção ėytem a função de expressar a possibilidade; já no v. 47a a conjunção subordinativa condicional ė vseguida da partícula de introduz uma oração interrogativa indireta. A partícula ah no v. 46b depois do verbo no imperfeito, tem a função de formação do futuro do pretérito, exprimindo possibilidade ou irrealidade no passado.
} 
envolvimento conversacional, e ter acesso ao sentido pretendido. Pois, apesar de todas as asseverações reveladoras (vv. 19d, 24a, 25a) de que o Deus único vivifica e julga "até agora" por meio do Filho, ainda não há uma adesão ou um "ato de fé" que os leve a interpretar as Escrituras como devem: a partir do Filho que se fez carne. As enunciações comunicativas finais do discurso persistem em interpelar os ouvintes cujas esperanças, continuam sendo postas, somente nas Escrituras Mosaicas. A falta de um ponto final na última enunciação acentua o dinamismo do texto, conferindo-lhe um sentido duradouro, algo para além do universo textual.

\section{4.}

\section{Conclusão}

As análises da coerência do texto de Jo 5,19-47, submetidas aos principais fatores de construção de coerência textual, e da coerência pragmática sob a ótica dos atos linguísticos, permitiram constatar relações (sintático-gramaticais, semânticas e pragmáticas) entre os elementos das sequências, de modo a perceber a textualidade responsável pela continuidade de sentido, portanto, por sua unidade textual. 


\section{5 \\ O texto de Jo 5,19-47 e seus motivos}

\section{1.}

\section{Identificação dos motivos}

A análise textual constatou o desenvolvimento do discurso através de vários temas secundários ou motivos, abordados detalhadamente, em grupos de tópicos, constituídos pelos argumentos que fazem acontecer a temática central. Com base nas características formais do texto é possível individuar seis motivos essenciais. Os critérios que permitem estabelecer esses motivos se distinguem, não só pelas marcas linguísticas literárias, mas também pelo lugar, pela pessoa que os pronuncia e pelo conteúdo temático.

Os três primeiros motivos apresentam semelhanças: nos critérios literários, pois são iniciados pela expressão "anhnn anhn I €gw uǹnhh" (vv. 19d; 24a; 25a); na situação espacial, repete-se o mesmo ambiente da esfera celeste; na pessoa do Filho que anuncia cada uma das divinas verdades reveladas nesses motivos.

O critério determinante do $4^{\circ}$ motivo (v. 30) é a apresentação do sujeito falante por meio do enfático pronome pessoal egw, Outro critério é a substituição da pessoa do Filho pelo egw,que assume sua identidade histórica na repetição do mesmo enunciado que abre o discurso no v. 19d. O conteúdo também é novo: aqui se apresenta a realização da verdade revelada pelo Filho no 'egw,' como vontade "daquele que o enviou". A delimitação com o quinto motivo é muito sutil. O critério é o termo chave "testemunho" requerido para a comprovação da realidade revelada. Porém no sexto motivo o critério linguístico mais forte são os pronomes pessoais de segunda pessoa do plural, e no nível do conteúdo o apelo à fé no enviado como a "Palavra do Pai". 


\subsection{1.}

A revelação da relação entre o Pai e o Filho na obra da salvação (vv. 19-23).

A revelação da relação Filho - Pai na obra da salvação constitui o pano de fundo do discurso. Um exame aprofundado permite destacar os principais argumentos que fundamentam a revelação dessa relação filial.

\section{a) A impossibilidade de "o Filho" agir independentemente do Pai}

A primeira enunciação do discurso: "O Filho, por si mesmo, nada pode fazer, senão aquilo que vê o Pai fazendo" (vv. 19d-19e), concerne à impossibilidade de "o Filho" agir independentemente do Pai, contrapondo-se, assim, ao preceito negativo "não é lícito/não é permitido. Declarando que não há ouden ( nada) que o Filho possa realizar sem manter o olhar fixo no Pai, o autor quer deixar claro que o Filho está em condições de fazer exatamente o que o Pai faz, em virtude da exclusividade de sua relação filial (cf. "Meu Pai”, 5,17). A visão do agir do Pai pelo Filho (v. 19e) condiciona a ação do Filho, de tal modo que não há senão unidade de ação entre os dois: "tauka (tudo) ${ }^{319}$ que este faz, o Filho faz de modo semelhante" (vv. 19f-19g). Esta relação filial tem como base a comunicação intensa existente entre os dois. O pronome substantivo panta (tudo) não permite nenhuma exceção, nem mesmo a de deixar de "fazer tais coisas em dia sábado" $(5,16)$.

O autor deixa transparecer, no modo como formula o discurso, uma clara intenção: quer evitar que Jesus dê a impressão de se colocar acima de Deus e ponha em perigo a sua unicidade e unidade; e ao mesmo tempo quer exprimir-se de maneira a afirmar que o único Deus está presente na ação do "homem" Jesus (cf. 5,8-9). O agir dos dois, significado em 5,17 com a forma verbal evgazeai (trabalhar) e nos vv. 21a-21b com o verbo poi eih (fazer), está especificado na dupla atividade de "dar vida e julgar" (vv. 21c-22a); atividades, até então, tidas e conhecidas como exclusivas do Pai. É esta a reivindicação de Jesus ao fazer uso da forma verbal exgażai em 5,17. O Filho está em total dependência do Pai ${ }^{320}$.

\footnotetext{
${ }^{319}$ O pronome demonstrativo neutro plural tauta foi usado como indefinido porque se refere a todas as coisas. Cf. FREIRE, A., Gramática grega, São Paulo: Livraria Amaral, 1982, p. 64.

${ }^{320}$ Cf. MUÑ̃Z LEÓN, D., Evangelio segun san Juan, In LEVORATTI, A. (Dir.)., Comentario Bíblico LatinoAmericano, Nuevo Testamento, Estella (Navarra): Verbo Divino, 2003, p. 620.
} 


\section{b) A autoridade que o Pai confere ao Filho se manifesta nas obras}

A autoridade do Filho é manifesta por suas obras; sua raiz não é outra, senão o amor do Pai pelo Filho que lhe revela panta(tudo): "porque o Pai ama o Filho e lhe mostra tudo que o que ele faz" (vv. 20a-20c). O verbo $\mathrm{fil}$ è/que aparece esta única vez no texto, quer sublinhar o privilégio da intimidade que confere autoridade ao Filho: numa relação de amor não existem segredos (cf. 10,17). O pronome tauka (v. 19f) expressa a totalidade da relação entre Pai e Filho, isto é, entre eles não há restrição de nada.

O verbo mostrar (dejknumi), no v. 20b no presente (déknusin) e no v. $20 \mathrm{~d}$ no futuro do modo indicativo (de xé), indica a constante atualidade desse mostrar - Elyj arti - e está em paralelismo com o bl epw (ver) do Filho (v. 19e). "O Pai lhe mostra tudo o que faz e lhe mostrará obras maiores para que vos admireis" (vv. 20b-20e). Com o indefinido panta fica excluída qualquer limitação no agir do Filho. O aspecto revelador do verbo "mostrar" junto à expressão "obras maiores" serve para expressar a manifestação do Filho por meio de seu agir, isto é, de suas obras.

Levantar os mortos e fazer viver (egeirein - zwopoièn vv. 21b-21c) é a primeira característica de Deus, que se manifesta nas obras de Jesus (egè rèn cf. 5,8). Realizar as obras que o Pai lhe deu para que ele as leve a termo (te é wsw) é o elemento mais característico de tal afinidade entre eles (cf. vv. 36b-c) ${ }^{321}$. A obra do Pai significa a comunhão de vida entre o Filho e o Pai. Fazer a vontade do Pai significa para o Filho o mandamento de dar a vida com a morte e de retomá-la com a ressurreição. Para isto serve sua exousi a (autoridade), não para o domínio, mas para o serviço do homem: o direito e a capacidade de comunicar-lhes a vida.

\section{c) $O$ agir do Filho concomitante ao do Pai. O Pai age na ação do Filho}

Para justificar-se perante a acusação dos judeus de transgredir o mandamento do repouso sabático (cf. Ex 31,12-17; 35,1ss), Jesus afirma: "Meu Pai trabalha até agora, e eu também trabalho" $(5,17)$. A afirmação de Jesus põe-se em desacordo com as prescrições judaicas que regem a lei do repouso sabático (cf.

${ }^{321}$ Cf. FERRARO, G., Il Paraclito, Cristo, Il Padre nel Quarto Vangelo, 1996, p. 30. 
Ex 31,12-17; 35,1s), geralmente, seguidas por todos os judeus ${ }^{322}$. A teologia hebraica tardia havia desenvolvido a doutrina do repouso sabático nesta síntese: "No sétimo dia Deus descansou do trabalho da criação do mundo, mas continua agindo no governo moral do universo, operando a salvação" ${ }^{323}$. Em sua declaração Jesus assume esta doutrina e põe ao lado do agir de Deus o próprio agir, colocando-se, ele mesmo, no mesmo plano do Pai. Tal afirmação soava a blasfêmia, como um atentado à unicidade de Deus: "Por isso, os judeus com mais empenho procuravam matá-lo, pois, além de violar o sábado, ele dizia ser Deus seu próprio Pai, fazendo-se, assim, igual a Deus" (cf. 5,18).

O agir do Filho não sucede ao do Pai, é-lhe concomitante. Seu agir próprio, derivado do agir do Pai, nada mais é do que este mesmo ${ }^{324}$. Esta enunciação traz presente "as obras" do Pai e, portanto, também, "as obras" do Filho, que são os atos divinos de dar vida e fazer julgamento, as duas atividades primordiais de Deus que não cessavam, nem podiam cessar no sábado. A ação criadora, dinâmica e eficaz do Pai se revela na história pelas obras do Filho. A presença da ação do Pai no Filho é diretamente expressa no v. 22: "O Pai, com efeito, não julga ninguém, mas concedeu (dedhken) todo julgamento ao Filho". O verbo didwnin é um termo expressivo para falar da relação do Filho com o Pai ${ }^{325}$. O Pai se revela como aquele que dá. É sua atitude fundamental. A vinculação do Filho com o Pai, a partir da mesma obra, é afirmada desde o início (vv. 19f e 19g): "Tudo que o Pai faz, o Filho igualmente faz" (vv. 19f e 19g).

\section{d) A finalidade da missão do "Enviado" e a exigência do reconhecimento da divindade do Filho}

O Filho é enviado pelo Pai para realizar uma missão divina (v. 22b; 23e). É tão completa a identidade de função e autoridade entre o Pai e o Filho, que é impossível prestar honra ao Pai, se se despreza o Filho: "Como o Pai levanta

${ }^{322}$ Segundo Manns e Ferraro, no que concerne ao repouso sabático, os testemunhos de que observam, escrupulosamente, as leis são numerosos: Rabi Hanina ben Dosa $(\operatorname{GenR} 10,84)$ e outros rabinos (T. Sab 13,9; Yoma 8,5; Sab 121a). Cf. MANNS, F., L'Évangile de Jean et la Sagesse, Studium Biblicum Franciscanum, Analecta 62, 2003, p. 44. Cf. também FERRARO, G., op. cit., p. 142.

${ }^{323}$ Para compreender essa resposta não se deve olhar somente para as prescrições judaicas. É importante considerar as exegeses judaicas que interpretam o repouso de Deus de Gn 2,2. Cf. WENGST, K., Il Vangello di Giovanni, Brescia: Queriniana, 2005, p. 209.

${ }^{324}$ Cf. LÉON-DUFOUR, X., Leitura do Evangelho segundo João, v. 2. São Paulo: Loyola, 1998, p. 38.

325 VANHOYE, A., Le Don du Christ, Lecture Spirituelle, Paris: Les Compagnons Philosophiques, 2005, p. 50. 
(egèr ) os mortos... assim também o Filho dá a vida (zwppoi ėł a quem quer" (v. 21a-21c). Por conseguinte, o Pai e o Filho são os doadores da vida divina, são vivificantes $^{326}$. O texto destaca as duas ideias fundamentais de vida e julgamento (zWh,e krișij), porque são os sinais da potência que levarão os homens a honrar o Filho como se honra o Pai, ou de rejeitar o Filho e, em consequência, rejeitar o Pai. Segundo o v. 21, a finalidade de o Filho exercer a função escatológica de "julgar" é para que todos honrem o Filho como honram o Pai (v. 23), isto é, que se reconheça a autoridade especificamente divina do Filho conferida pelo Pai ao delegar-lhe as atividades de dar vida e de julgar: "Pois o Pai a ninguém julga, mas confiou-lhe todo o julgamento" (vv. 22a-22b). Qualquer que seja a subordinação funcional que possa ser enfatizada nessa sequência, ela garante, conforme os vv. 19-20, que "o Filho faz tudo que o Pai faz", e que, portanto, o Filho possa ser um com o Pai não só em atividade, mas também em honra ${ }^{327}$. Não só a relação filial, mas também, a missão divina o distingue de outros filhos e enviados.

O texto, ao admitir que o propósito do Pai é que todos honrem o Filho, conclui: "Quem não honra o Filho, também não honra o Pai que o enviou" (vv. 23c-d-e). Agora que o Filho veio como "enviado", porquanto representa e revela o Pai, a pessoa que nega a honra devida ao Filho desonra da mesma forma o Pai.

\subsection{2. \\ O caráter revelador da Palavra do Enviado, portadora do dom da vida eterna ( $v .24)$}

O caráter revelador da "Palavra do Enviado" está assinalado por sua íntima relação com quem o enviou. Ele fala a palavra de quem o enviou: "Quem escuta (akoue n) a minha palavra e crê naquele que me enviou tem vida eterna, e não vem a julgamento, mas passou da morte à vida" (v. 24). É esse paralelismo entre "escutar a palavra do Enviado" e "crer Naquele que o enviou" que permite captar a identidade da "palavra" como autorrevelação divina e doadora de vida eterna. O sentido da palavra passa para o primeiro plano. Ela é o veículo da vontade criadora e salvadora de Deus. Deus age falando. O fato de o verbo akoum no v. $24 \mathrm{~b}$ aparecer em sentido absoluto sinaliza para o seu sentido revelatório: o ato de

\footnotetext{
${ }^{326}$ FERRARO, G., Il Paraclito, Cristo, Il Padre nel Quarto Vangelo, p. 145.

${ }^{327}$ CARSON, D. A., O comentário do Evangelho de João, São Paulo: Shedd Publicações, 2007, p. 256.
} 
escutar a palavra do "Enviado" realiza o ato de crer "Naquele" que o enviou. A palavra do Enviado do Pai é sua autoexpressão, seu próprio Filho ("Quem crê em mim, não é em mim que crê, mas naquele que me enviou". cf. 12,44).

A promessa de "passar da morte à vida sem vir a julgamento", que vem a seguir (vv. 24e, 24f, 24g), confirma a importância da recepção dessa "Palavra", que, por ser equivalente à "Palavra" do Pai ("Aquele que Deus enviou fala as palavras de Deus", cf. 3,34$)^{328}$, é portadora da grande revelação de que "o dom da vida eterna" já pode ser recebido, no presente, por aqueles que escutam a palavra vivificadora do "Enviado". A Fé no Filho que o Pai enviou e que fala as palavras de Deus é a condição para se atingir a Vida Eterna. A obra de vivificação torna-se efetiva quando se ouve a palavra (v. 24 ; cf. 5,8 ), porque é a própria palavra de quem o enviou. O poder de viver é dado na Palavra do "Enviado", pois nele a morte não é mais aquilo que era.

O crente é descrito como aquele que ouve a palavra do enviado e crê no que o enviou. Por conseguinte, se estabelece entre o enviado e o crente uma relação de causa e efeito: tal crente não vem a juízo. A palavra do enviado é uma realidade ativa, uma realidade que julga, que dá vida; suas palavras são "espírito e vida" $(6,63)$, são palavras de "vida eterna" $(6,68)$. A fé em tal revelação oferece a vida eterna aos crentes, sem negar que o ato de fé nasce de uma opção (Quem escuta minha palavra...). É pelo poder da "Palavra" que o Filho, enviado do Pai, comunica a vida (v. 24) e faz Deus presente. Para o autor, a verdadeira morte é aquela que separa o homem de Deus, fonte da vida.

\subsection{3.}

As duas dimensões do acontecimento do envio do Filho (vv. 25-29)

Segue-se, à promessa do dom da vida eterna aos que escutam a palavra e creem na missão escatológica do Enviado, o anúncio da w[a (hora) de sua chegada. Esse é feito em termos de tempo presente: nuh estin (é agora, v. 25c) e em termos de futuro erceai wra (vem a hora, v. 28b). Com o envio do Filho que fala as palavras do Pai, os "nekra'," (os mortos) "ouvirão a voz do Filho de Deus e os que a ouvirem viverão".

${ }^{328}$ Cf. Também 14,24a: "e a palavra que ouvistes de mim não é minha, mas do Pai que me enviou"; cf. 6,63; 7,17; 8,28; 8,38. 40; 14,10; 18,37. 
Nos versículos 25-27, os conceitos de vida e julgamento adquirem um desenvolvimento peculiar como realidades presentes com uma projeção futura (os mortos ouvirão... viverão). A autoridade de juiz (v. 27a) corresponde à honra atribuída ao Filho no v. 23. O termo exousia (v. 27a) designa um poder exercido com plena autoridade. O Filho é apresentado no papel de "Filho do Homem" (27b), portanto, com um enunciado de uma função escatológica: é o papel de juiz que aparece confirmado pelo título "Filho do Homem". A alternativa vida/julgamento (vv. 29b-29c), retomada aqui em uma dimensão futura, com traços da literatura apocalíptica, expressa o absoluto do dom oferecido por meio da "palavra" do Filho, cuja voz, ressoando nos sepulcros, abrange todos os tempos e situações.

A revelação da chegada da "obra" escatológica do Pai realiza-se por meio da voz do Filho que chama todos a ressuscitar (v. 28d-29b). Ela é uma realização divina. Ressuscitar mortos era uma característica do próprio Deus ${ }^{329}$. Assim Deus cumpre sua obra escatológica, consistente no vivificar e ressuscitar os mortos, no Filho e por meio do Filho: "o’ pathr egeirè touj nekraij kai. zuppoiej" (vv. 21a-21b).

\subsection{4. \\ A autorrevelação da pessoa do "Filho", do "Enviado" e do "Filho do Homem" (v. 30)}

Agora a pessoa do "Filho", também manifestado por sua missão como "Enviado" (v. 24) e como mediador do julgamento - "Filho do Homem"- (v. 27b), assume sua identidade histórica se autorrevelando por meio do pronome pessoal "Egw", que substitui o nome "Jesus" do v. 19a e o de Filho do v. 19d. Aqui está afirmada a identificação entre o Enviado, o Filho de Deus, o Filho do Homem e Jesus; uma pessoa individual com a função de julgar e salvar (vv. 25d; 26b-27b; $30 b)$.

A ideia da unidade com o Pai é retomada no v. 30a juntamente com o tema do julgamento confiado à missão do Filho (v. 22b) e que está acima de sua própria vontade: "porque não procuro a minha vontade, mas a vontade do que me enviou". O Pai, única fonte de uma vida autêntica e de um juízo justo, confiou ao

${ }^{329}$ Cf. 1 Sm 2,6; 2 Rs 5,7; Ez 37,13. 
Filho a comunicação desta vida e a responsabilidade desse juízo (vv. 30a-b). O discurso continua a insistir que, o que o Pai faz, o Filho também faz, e que exerce a missão de fazer julgamento a qual the foi confiada conforme a vontade de quem o enviou (v. 30e), destacando novamente a humilde obediência à vontade do Pai (v. 30d), agora, segundo o que ele "ouve" (akoum v. 30b) ${ }^{330}$.

A expressão mais característica na personalização que Jesus faz de si mesmo está demonstrada, não só pelo pronome pessoal egw, (v. 30a), mas também pelos possessivos "exh. krișij" (meu julgamento, v. 30c) e "exon tel ena" (minha vontade, v. 30d) e o pronome oblíquo de primeira pessoa ne(v. 30e). A vontade do Filho é dar a vida e no relato do texto 5,1-18 está expressa na pergunta de Jesus ao paralítico: "queres ficar curado?" (cf. 5,6).

\subsection{5.}

A legitimação da reivindicação do Filho (vv. 31-39)

A identificação da pessoa do Filho (v. 19d), enviado para dar vida e fazer julgamento, com a pessoa de Jesus (v. 30a) exige legitimação. Fé em Jesus enviado pelo Pai. O tema do testemunho que domina a sequência dos vv. 31-39 apresenta uma pluralidade de testemunhos, que tem por escopo mostrar que o Filho é Jesus e que nele age o $\mathrm{Pai}^{331}$. $\mathrm{O}$ autor recorre à fórmula judaica da terminologia testemunhal para a averiguação da verdade explicitada (cf. 8,13s). O testemunho de João Batista é definido como um testemunho dado à verdade (v. 33b). Uma vez que estão em discussão as pretensões divinas de Jesus, testemunhos humanos não podem ser válidos. Jesus apela para as obras que faz, para o Pai e para as Escrituras ${ }^{332}$.

Deve-se constatar em primeiro lugar que o testemunho não é plural: o do Pai é dado através de João Batista ${ }^{333}$. O testemunho do Pai se dá também através das Escrituras (vv. 38-39), e mediante "as obras", pois são propriamente as obras do Pai que Jesus realiza (v. 36b). Jesus sempre se refere à sua atuação, empregando o termo "obra" (v. 36b; cf. 4,34; 7,21; 14,10-12; 17,4) ${ }^{334}$. As obras de Deus

\footnotetext{
${ }^{330}$ No v. 19e o verbo "ver" ocupa o lugar do verbo "ouvir" no v. 30a.

${ }^{331}$ Cf. TUÑI VANCELS, O. J., O testemunho do Evangelho de João, Petrópolis: Vozes, 1989, p. 90.

${ }^{332}$ MANNS, F., L'Évangile de Jean à la Lumière du Judaïsme, Studium Biblicum Franciscanum, Analecta 33, 1991, p. 64.

${ }^{333}$ É o Pai quem fala através dele: "Quem me enviou para batizar..." (cf. 1,33).

${ }^{334}$ Cf. TUÑI VANCELS, O. J., op. cit., p. 90.
} 
realizadas por Jesus revelam-no como Filho. A autoridade desses testemunhos é real, porém, secundária. É o Pai que dá testemunho segundo seu desígnio. Esse é o único testemunho plenamente satisfatório, porque só aí se pode evitar a tentação de ficar no puramente testemunhal, sem considerar o conteúdo testificado. Devese estar atento ao conteúdo do que se atesta: a justificação divina da missão de Jesus aos que o haviam aceitado ${ }^{335}$.

Talvez, portanto, essa lista de testemunhos tenha também o sentido revelador que tem o testemunho de Jesus que ouviu a voz de Deus e contemplou a sua face (vv. 37c- 37d). Toda atividade de Jesus caracteriza-se como uma revelação idêntica ao seu testemunhar, definindo, assim, sua atuação no mundo: a identidade entre o seu falar e o seu testemunho. "As obras que eu faço testemunham sobre mim” (vv. 36d-36e). A palavra é inseparável dos seus atos e explica o sentido e o alcance deles. Eis o fundo da revelação: a unidade de ação e unidade de ser entre o Pai e o Filho manifestada pela Palavra. O falar de Jesus é uma revelação, pois o Evangelho já tem afirmado que ele é a Palavra do Pai que se fez carne $(1,14)$.

Por conseguinte, o testemunho desta pluralidade de testemunhos se reduz, ao de Jesus. Toda a atividade de Jesus é, portanto, uma obra que o Pai lhe deu a fim de realizá-la e levá-la à perfeição (v. 36c; cf. 19,30); portanto, toda a missão do "Enviado" se realiza no cumprimento da vontade do Pai e em total dependência ao seu plano salvífico (vv. 36b-36c; cf. 4,34).

\subsection{6.}

\section{Jesus, o Filho, o hermeneuta da Palavra das Escrituras (vv. 40-47)}

As Escrituras não só testemunham a ação de Deus em Jesus, mas, exclusivamente, são por ele interpretadas. Apesar dos testemunhos, não houve aceitação (I anbanny) da reivindicação de Jesus (v. 43b). Observa-se nos interlocutores uma atitude de fechamento (v. 40a). De fato, a rejeição de Jesus, de suas obras e de suas palavras ocupa um lugar central nesse texto (vv. 38a-38b), especialmente nos vv. 40-47, nos quais se aprofundam as raízes dessa rejeição. A incredulidade é apresentada como uma rejeição à vida (vv. 40a-40b), como o não reconhecimento da glória devida ao "Enviado" (v. 41), como a ausência do amor

${ }^{335}$ Cf. TUÑI VANCELS, O. J., O testemunho do Evangelho de João, p. 91. 
de Deus (v. 42b), como uma recusa a acolher aquele que vem "em nome do Pai" (vv. 43a-43b), como falta de vontade em crer e reconhecer a manifestação da glória que vem do "Deus único" (v. 44).

Essa rejeição é apresentada num duplo momento: a rejeição histórica de Jesus e a rejeição de suas palavras, de sua doutrina e de seu ensinamento. A palavra de Jesus é critério para a fé e, portanto, também para a incredulidade, pois essa palavra quer abrir passagem entre os interlocutores e eles não permitem: "Não tendes a Palavra do Pai permanecendo em vós" (v. 38a; cf. 8,37. 43). Há aqui uma chamada de Jesus para a aceitação de uma realidade palpável e concreta. Crer, finalmente, é possuir a palavra (vv. 38b-38c). Portanto, a incredulidade é fechar-se a Jesus, o que ficará evidente no fechar-se às suas palavras (minhas palavras, v. 47) e às suas obras. Para poder acolher a palavra, é preciso que, antes, se esteja aberto e disponível. O ato de fé em Jesus que fala a Palavra do Pai é dom e obra de Deus (cf. 6,28-29); portanto, a fé em Jesus é a obra de Deus (cf. 6,44). Se a incredulidade é apresentada como uma rejeição da Palavra de Deus (cf. 14,10-11), então as Escrituras estão sendo rejeitadas e, por conseguinte, Moisés é quem os acusará (v. 45c), pois foi a respeito de Jesus, a "Palavra encarnada" que revela o Pai, que ele escreveu (v. 46c).

A sequência dos vv. 44a-47b, em forma de inclusão, inicia-se e é concluída com o advérbio pw', como elemento de finalização. Falta aqui no "pw్'”" (como) a força da identidade entre a relação Pai - Filho e a relação Filho - crentes/ouvintes. O comportamento do ouvinte precisa passar para o nível do crer, pois o como da relação Pai - Filho, não é imitável, vem do alto, é dom e não mandamento. O próprio Filho comunica, porque o recebe de experiência vivida conjuntamente pelo Pai e pelo Filho, e na qual o Filho introduz os que o recebem. Uma verdadeira hermenêutica das Escrituras abrirá a possibilidade de acolhê-lo (v. 47).

\section{2.}

\section{A semântica dos motivos}

\subsection{1.}

A semântica do primeiro motivo (vv. 19-23).

O primeiro motivo se articula em torno da ideia central da filiação divina de Jesus e procura mostrar que não há impedimentos doutrinais para a aceitação 
dessa afirmação ${ }^{336}$. Para desenvolver os argumentos necessários a essa finalidade, o autor trabalha com vocábulos reduzidos, porém com termos de muita relevância semântica para seus ouvintes/leitores. A alta concentração dos vocábulos pathr e ui òj no texto (vv. 19d-23e) é indício de que o autor quer trazer à reflexão a questão cristológica sobre a relação de Jesus com Deus, a quem ele chama "meu Pai” $(5,17)$. O termo pathr, ao vir sempre determinado pelo artigo o` (o` pathr), quer pôr em relevo a relação de Jesus, o Filho, com Deus, o Pai ${ }^{337}$. Segundo Ferraro, o autor mostra antes de tudo a dependência do Filho ao Pai no seu agir servindo-se da conhecida parábola do "filho aprendiz" (vv. 19-20) tomada da vida artesanal, no qual todo filho aprende o ofício, observando o próprio pai executar sua arte, na qual comunica ao próprio filho os segredos de seu ofício ${ }^{338}$.

O conceito de paternidade de Deus não foi originado no Novo Testamento, tem uma longa história pré-cristã $\tilde{a}^{339}$, cujo ponto culminante, segundo J.

\footnotetext{
${ }^{336}$ Cf. LÉON-DUFOUR, X., Leitura do Evangelho segundo João, p. 18.

${ }^{337}$ É um termo essencial da teologia Joanina e, no Novo Testamento, o termo pathr aparece 414 vezes, das quais 250 se referem a Deus e mais de 150 a homens. A maioria dos testemunhos se encontra no Evangelho de João (136 vezes; Mt 63; Mc 19; Lc 56; Paulo 40). Jesus mesmo fala de Deus como Pai três vezes em Mc; 4 vezes em trechos que Mt e Lc têm em comum, 4 vezes em trechos que se acham só em Lc, 31 vezes no restante de Mt (sem incluir o material de Q e o de Mc) e 100 vezes no Evangelho de João. Na estrutura patriarcal do mundo antigo, o pai é o protetor, o que proporciona alimento, a quem se deve respeito, tendo autoridade absoluta sobre a família. No sentido metafórico, pathr se aplica ao rei, aos mestres e, mais ainda, a Deus mesmo. O emprego religioso da figura do pai é um dos fenômenos básicos da história das religiões. Na oração, em textos sumérios já se invocava Deus como Pai. Cf. COENEN, L.; BROWN, C., DITNT, v. 2, São Paulo: Vida Nova, 2000, p. 1500 et seq.

${ }^{338}$ Cf. FERRARO, G., Il Paraclito, Cristo, Il Padre nel Quarto Vangelo, p. 143.

${ }^{339}$ Em Israel, a conexão entre Deus e Pai é feita biblicamente por meio da eleição, do pacto e da promessa de salvação feita a Israel (cf. Dt 32,6. 2; Sm 7,14; Sl 2,7; Jr 31,9). Em síntese, a relação bíblica entre pai e filho está ligada sempre a requisitos prévios que se expõem, e aos que têm que prestar conta na obediência e na fidelidade (cf. Dt 14,1). Em 1 QH 9, 35s: "Porque tu és um Pai para todos os filhos de tua verdade". A origem de sua ampliação deu-se no judaísmo rabínico antigo, provavelmente pelas liturgias (cf. Eclo 51,10; Tb 13,4; Jub 1,24. 28; 19,29). A Sinagoga helenista seguiu a tradição da LXX com forte acentuação da tradição palestinense (cf. $1 \mathrm{Cr}$ 29,16 com Josefo, Ant. VII, 380): a ideia de Pai como Criador, Origem de tudo e Protetor. É importante constatar que, na tradição judaica da diáspora, a invocação de Deus como Pai é muito empregada em doxologias (cf. 3 Esd 4,60; Sb 14,3). Os "Pais" e o "Deus dos Pais": as promessas feitas aos Pais e as bênçãos a eles indivisíveis estão como pano de fundo da mensagem do NT e o legitimam: Deus como Pai é o Criador e também o Redentor (cf. Ef 3,14). Com a fundação da Igreja cristã encontra-se uma nova forma litúrgica e didática (oração, bênção e confissão de fé). Paulo fala de "Deus, o Pai", "Deus, nosso Pai", "O Pai de nosso Senhor Jesus Cristo" (cf. Rm 1,7; 1 Cor 1,3; 2 Cor 1,2; 2 Cor 1,2; Gl 1,3 e passim). Esta forma doutrinal é bimembre, porque se amplia para incluir o senhorio de Jesus Cristo. No estilo da shemá (Dt 6,4 LXX) se acentua a unidade de Deus, o Pai, e a confissão de fé no senhorio de Jesus Cristo aparece como uma ampliação e explicação, não como uma limitação do enunciado acerca de Deus como Pai. Isto recorda a passagem de Ex 4,16, quando Moisés deve falar a Aarão, fazendo as vezes de Deus, ou quando Moisés sobe à montanha e dialoga com Deus (Ex 24,15-18). Talvez se possa ver aqui também a conexão joanina entre a relação Pai - Filho e a legitimação do mensageiro por parte de quem o envia (cf. Jo 17,13). Cf. MICHEL, O., verbete pathr In BALZ, H.; SCHNEIDER, G., DENT, v. 2, Salamanca: Sigueme, 1998 , p. 828 et seq.
} 
Jeremias $^{340}$ é a mensagem profética sobre o infalível amor paternal de Deus. Conforme O. Michel ${ }^{341}$, a invocação a Deus como aldba, remonta ao costume mesmo de orar que tinha Jesus e os cristãos de fala aramaica (cf. Rm 8,15; Gl $6,4)$. Trata-se, portanto, aqui de uma relação excepcional, mais ainda, exclusiva entre o Pai e o Filho, que não tem paralelos no judaísmo do AT, mas que pode ter suas raízes nos hassidim da Galileia, cuja experiência de Jesus ajudou a ampliá-la e aprofundá-la ${ }^{342}$.

Quando se confronta, nestes versículos 19d-23e, e no texto todo (vv. 19-47), as relações de Jesus com Deus, é algo tão surpreendente e tão tipicamente joanino que merece uma atenção especial ${ }^{343}$. Jesus tem um relacionamento único com o Pai, que se comunica aos homens através de seu Filho, dando-lhe poder e autoridade para realizar sua missão salvífica (vv. 19d-23e). O Filho ${ }^{344}$ está em uma relação tão estreita com o Pai que é objeto de seu peculiar amor (v. 20; cf. 3,$35 ; 10,17$ ), devendo merecer as mesmas honras que são devidas ao Pai (v. 23). Nesse Evangelho o Pai é o Pai de Jesus.

\footnotetext{
${ }^{340}$ Com Jesus aparece, como uma novidade, a invocação de Deus pelo termo aramaico abblo, (papai), termo este usado em casa pelos filhos ao dirigir-se ao pai, e cujo equivalente, no feminino, era o termo i Mma,(mamãe), e que não se encontra em nenhum texto de orações judaicas. Que Jesus invocava a Deus como Pai, em atitude familiar em todas suas preces, usando o termo abba, pode-se argumentar com as citações do Novo Testamento, especialmente em Mc 14,36. O aldba,neste apelo em forma de oração reflete a invocação de Deus que era comum nas orações de Jesus (cf. Mt 11,25s; 10,32; Lc 10,21). Cf. JEREMIAS, J., ABBA Jésus et son Père, Paris: Éditions Du Cerf, 1972 , p. 8.

${ }^{341}$ Conforme O. Michel, as orações sinagogais daquela época (cf. Ef 4,5-6; Mt 6,9; e também Mt 6, 5-8. 26; 7,11; 10,29ss; 18,34; Lc 11,13) deviam ser formuladas originalmente em hebraico (ba') ou aramaico (transcrito para o grego como $\backslash$ abba). Cf. MICHEL, O., verbete pathr In BALZ, H.; SCHNEIDER, G., op. cit., p. 828 et seq.

${ }^{342}$ Cf. Id., Ibid.

${ }^{343}$ GUILLET, J., Jesus Cristo no Evangelho de João, São Paulo: Paulinas, 1985, p. 53 et seq.

${ }^{344}$ Vários autores interpretam a forma impessoal do v. $19 \mathrm{~d}$ como sendo uma parábola popular, expressão de uma verdade de experiência, segundo a qual só um pai e um filho se conhecem realmente, e o filho aprende vendo o pai trabalhar porque lhe comunica o segredo de sua arte. Cf. JEREMIAS, J., op. cit., p. 53; Cf. FERRARO, G., Il Paraclito, Cristo, Il Padre nel Quarto Vangelo, p. 143; Cf. MANNS, F., L'Évangile de Jean et la Sagesse, p. 147; Segundo Dodd, os vv. 19-20a exprimem uma parábola pré-joanina. Cf. DODD, C. H., Une parabole cachée dans le quatriéme Évangile, In RHPhR 42, 1962, pp. 107-115; Brown também está de acordo com esse pensamento. Cf. BROWN, R., El Evangelio según Juan, v. 2, Madrid: Cristiandad, 1979, p. 423. Tal interpretação, entretanto é vigorosamente recusada por outros, como SCHNACKENBURG, R., El Evangelio según San Juan, v. 2, Salamanca: Herder, 1980, p. 140; LÉON-DUFOUR, X., Leitura do Evangelho segundo João, v. 2, p. 36; Carson argumenta que o caso está longe de ser universal e não responde ao sentido próprio da fórmula, a qual se apresenta, ao contrário, como um caso único. Para estes exegetas, o sentido principal do v. 19 é que qualquer que seja o sentido de "igualar-se a Deus", isso, para Jesus, não significa completa independência do Pai, nem mesmo parcial. Cf. CARSON, D. A., O comentário do Evangelho de João, p. 251.
} 
O termo uiòj aparece, também, nesse texto, sempre determinado: o ui òj ${ }^{345}$. O uso absoluto de o ui ò ${ }^{346}$ no v. 19d indica tratar-se de uma das reivindicações fundamentais que o autor atribui a Jesus. Esse propósito essencial da teologia e da cristologia joaninas se revela na autodesignação de Jesus como "O Filho". No Evangelho de João a singularidade do envio de Jesus e a relevância de suas palavras e feitos se expressam mediante a peculiaridade de suas relações com Deus, e mais concretamente através de sua relação filial ${ }^{347}$.

A relação "Pai - Filho", revelada no Prólogo, é a chave para a compreensão do Jesus joanino, o "Revelador do Pai": nonogenhj qeg o`wh ejj ton kol pon toul patroj ekė hoj enghsato (v. 1,18). "O Filho”, Jesus, é o único que revela o Pai $(1,18)$. Jesus é o unigênito gerado pelo Pai $(1,14$. 18). Somente Jesus conhece o Pai $(1,18 ; 6,46 ; 10,15)$. Jesus e o Pai são um só $(10,30 ; 14,9 b-11)$. Essa comunhão de vida, proclamada desde o Prólogo “o’ I ogoj h₹ proj ton qeon” (v. 1,1b) permeia todo o Evangelho: "Não estou só, porque o Pai que me enviou está comigo" (cf. 8,16b; 8,29). Especialmente no capítulo 14 está expressa de maneira muito clara ${ }^{348}$. Devem ser consideradas no mesmo relevo cristológico as expressões nas quais o Jesus joanino fala "do Pai",349 ou de "meu Pai" 350 . No aspecto formal, o Evangelho de João é o que mais põe em relevo a relação Pai Filho e, de fato, isso ocorre nesse texto $(5,19-47)^{351}$.

\footnotetext{
${ }^{345}$ Conforme Carson, a expressão o 'ui òj é em João uma expressão cristológica padrão. Esse termo reaparecerá nesse texto oito vezes, sem contar com o pronome aukou/ (vv. 20b, 20d, 27a, 28d), referente ao Filho, antes de ser substituído pelo egw, (Eu) de Jesus nos vv. 30a, 31a, 34a, 36a, 43a, 45b; tal concentração só aparece aqui em João. Cf. CARSON, D. A., op. cit., p. 251.

345 "O Filho" em forma absoluta se encontra 18 vezes em Jo e 4 vezes nos Sinóticos (Mc 1,11; 9,7; 12,6; 13,32; Mt 11,27 e par.). GUILLET, J., op. cit., p. 53 et seq.

${ }^{345}$ Segundo F. Manns, João emprega o termo viòj precedido do artigo ò para precisar que se trata do Filho único a quem pertence a herança. Cf. MANNS, F., op.cit., p. 147. No entanto, para J. Jeremias o artigo "o" pode também ter um sentido genérico. O Filho designaria assim um filho. Para ele, o uso do artigo é um semitismo corrente em parábolas. Cf. JEREMIAS, J., op. cit., p. 53.

346 "O Filho" em forma absoluta se encontra 18 vezes em Jo e 4 vezes nos Sinóticos (Mc 1,11; 9,7; 12,6; 13,32; Mt 11,27 e par.). GUILLET, J., op. cit., p. 53 et seq.

${ }^{347}$ Ibid., p. 53 et seq.

${ }^{348}$ Cf. Jo 14: "Quem me viu, viu o Pai" (v. 9); "Não crês que eu estou no Pai e o Pai em mim?" (v. 10a); "Mas o Pai, que permanece em mim, realiza suas obras" (v. 10c); "Crede-me: eu estou no Pai e o Pai está em mim" (v. 11); "a fim de que o Pai seja glorificado no Filho" (v. 13); e no v. 31: "Mas o mundo saberá que amo o Pai e faço como o Pai me ordenou".

${ }^{349}$ Só no primeiro motivo o termo Pai aparece seis vezes. No Evangelho de João são numerosas as citações de Jesus falando do Pai (136 vezes).

${ }^{350}$ Com o pronome possessivo "meu": 5,17; cf. 2,16; 14,2. 23; 15,8. 23. 24; 20,17.

${ }^{351}$ Não se faz necessário, para nosso propósito, apresentar o imenso material que o Evangelho oferece sobre essa relação.
} 
A enunciação que sustenta o primeiro motivo: "O Filho, por si mesmo, nada pode fazer (poi ein) ${ }^{352}$, senão aquilo que vê o Pai fazer" (poi ounta), joga com o campo semântico de poi $e N^{353}$. A forma verbal poi ėh designa a atuação criadora, a atuação histórica e a atuação escatológica futura de Deus ${ }^{354}$. O sujeito de poi ené com especial frequência o Pai ou o Filho, e está sempre na voz ativa ${ }^{355}$. O fazer de Deus é manifestado por suas obras.

No Evangelho o termo erga está relacionado à manifestação das obras de Deus $(9,3 \mathrm{~s} ; 10,25$. 32. 37s; 14,10. 12). O substantivo ergon é um termo expressivo para o evangelista e nesse texto só aparece no plural €ga (v. 20d) e em relação direta com o Pai: é o Pai quem mostra "as obras" ao Filho, quem the dá a tarefa de concluí-las e, por isso, ao "fazê-las", elas testemunham a “identidade do Filho". A obra de Jesus dá testemunho de que Jesus é o Filho. As obras que Jesus faz, são as obras que o Pai lhe deu para consumá-las e são elas que testemunham que o Pai lhe enviou (v. 36c; 10,20). É a obra confiada ao Filho pelo Pai. O Filho é enviado do Pai e age em seu nome. Como coisa dada por Deus, a obra de Jesus designa a totalidade da ação reveladora levada a cabo por Jesus (te e w\$sw v. 36c) ) $^{356}$. No versículo 36, “As obras que o Pai me encarregou

\footnotetext{
${ }^{352}$ No Evangelho, a expressão "nada fazer por si mesmo" aparece em 7,18; 11,51; 15,4; 16,13; 18,34. Essa expressão possui um passado na Bíblia e nos escritos do judaísmo. Ela aparece em Nm 16,28-31, na boca de Moisés, ao se confrontar com os revoltados Coré, Datã e Abiram. Segundo Léon-Dufour, Jesus retoma o que há de essencial na declaração de Moisés: "Não os fiz por mim mesmo". A tradição judaica conservara esta palavra como critério que permitia discernir os milagres autênticos dos prodígios operados pelos falsos profetas; ela se torna o lugar teológico para reconhecer os enviados de Deus. Jesus se situa, pois, na linha certa da tradição mosaica e dos grandes enviados de Deus; mas se ele responde assim à exigência implícita dos judeus ofendidos com a cura do enfermo em dia de sábado, sua palavra é bem mais radical: não há nada que o Filho possa realizar sem manter o olhar fixo no Pai. Cf. LÉON-DUFOUR, X., Leitura do Evangelho segundo João, p. 37. Segundo Schnackenburg, "por si mesmo" ou "por sua própria iniciativa não pode fazer nada", isto é, não agir por si mesmo, desempenha um papel importante nos discursos de revelação no Quarto Evangelho em suas respostas aos judeus como em 7,18; 8,28; 14,10. Cf. SCHNACKENBURG, R., El Evangelio según San Juan, pp. 140-141.

${ }^{353}$ Conforme Keener, afirmando que Deus é seu Pai, Jesus explica sua própria ação por meio de uma analogia de um filho que imita e obedece a seu pai. Cf. KEENER, C. S., The Gospel of John, A Commentary, v. 1, Massachussetts: Hendrickson Publishers, 2005, p. 648.

${ }^{354}$ Cf. BÍBLIA SEPTUAGINTA (Gn 1,1). A Septuaginta traduz o verbo "criar" do hebraico arB no livro do Gênesis 1,1.21. 27a. 27b. 27c por poi eN. Gn 1,16 e 25 traduz o verbo hebraico hf ['por poi eN e Gn 1,26 hf['(hfโt) por poieN. Conferir também no AT: Ex 20,11; Sl 145, 6 LXX; nos livros Sapienciais; No NT: Lc 11,50; At 4,24; 14,15; 17,26. Cf. RADL, W., verbete poi $\Theta N$ In BALZ, H.; SCHNEIDER, G., DENT, p. 1041.

${ }^{355}$ No texto aparece onze vezes, incluindo a forma composta zuppoi $\dot{\theta} /$ No Evangelho, 110 vezes. Relacionado ao fazer do Pai e/ou ao do Filho, isto é, à sua obra, esta forma verbal (poi en) aparece nos versículos 19d; 19e; 19f, 19g, 20c; 21b; 21c; 27a; 29b; 30a; 36d, e zuppoi e'/nos vv. 21b e 21c. ${ }^{356}$ Segundo Manns, para quem as "obras" que Jesus realizou são, conforme a tradição judaica sapiencial, "obras de misericórdia", Jesus teria visitado os doentes descritos na piscina em Jo 5, praticando uma obra de misericórdia, pois o nome da piscina pode ter o sentido de Casa da
} 
de consumar" (te e wş) traduz na LXX o "concluir" (hl K) do Gênesis ${ }^{357}$ (Gn 2,2). É significante que o termo obra (๔rgon) aqui possa ser aplicado aos atos de Deus na criação ${ }^{358}$. Em João, no singular, o termo ergon sublinha a unidade da obra (cf. 7,21), significando a obra de revelação e de salvação que o Cristo realiza. Ela define a ação de Jesus. A intenção de todo o Evangelho é mostrar como a obra de Cristo é evidente por si mesma; suas obras são luminosas (v. 36; 14,2). "As obras que eu faço em nome de meu Pai dão testemunho de mim" (cf. 10,20).

No texto de Jo 5,19-47, a forma verbal dunanai condiciona o ato do "fazer" à autoridade do Pai e o limita ao enviado (vv. 19d e 19e): o poder de fazer é só para quem vê o Pai fazer. A forma verbal dunanai (poder, ser capaz) tem um significado especial, no Evangelho de João, de poder divino, no qual falta o substantivo dunaninj. O evangelista o usa em relação com os sinais de Jesus (3,2; $9,2 ; 10,21)$, nos quais se revela o poder de Deus ou se o questiona. As curas praticadas por Jesus servem de argumentos de seu poder divino ${ }^{359}$. O poder de Jesus nasce de sua comunhão com Deus (vv. 19. 30; 12,49).

Associado ao mesmo campo semântico de dunanai está a forma verbal bl epw que tem o significado fundamental de ver, apreender visualmente, contemplar $^{360}$. O verbo ver em João em muitos casos tem também o sentido de aceitação, de crer, de visão que penetra a superfície (cf. Jo 6,26; 9,36ss) ${ }^{361}$. Não é fácil fazer uma distinção nítida entre os numerosos verbos que exprimem em João

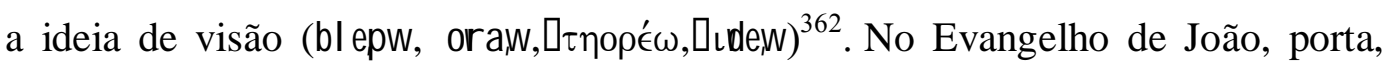
especialmente, o sentido do ato testemunhante de ver, de presenciar o poder (b epw v. 19e), e contemplar a face de Deus (araw, [v. 37d). Ver para João é uma nova experiência sensível que nasce do encontro total e existencial com a

Misericórdia. Cf. MANNS, F., L'Évangile de Jean et la Sagesse, p. 88. Para Muñoz Léon é pouco provável essa proposta de Manns, pois as obras no capítulo 5 pertencem ao campo semântico das obras de Deus na criação. Cf. MUÑOZ LÉÓN, D., Evangelio según san Juan In LEVORATTI, A. J.; TAMEZ, E.; RICHARD, P., Comentário Bíblico Latinoamericano, Nuevo Testamento, Estella (Navarra): Verbo Divino, 2003, p. 620 et seq.

${ }^{357}$ No texto grego da LXX o verbo que traduz o hebraico hl K é suntel eN.

${ }^{358}$ Para Manns, o termo ergon está associado à criação nos livros da Sabedoria $(\mathrm{Sb} 13,1)$ e no Sirácida (Sir 42,15s). Ele nota a tendência do IV Evangelho, herdada dos meios sapienciais, de reduzir as noções principais do plural ao singular. É a questão das obras, em seguida, da obra de Jesus. Pois, para este exegeta, o sentido no plural erga (vv. 20d e 36b e 36d) designa as ações de Jesus em favor da vida: as obras de misericórdia. Cf. MANNS, F., op. cit., p. 148.

${ }^{359}$ KELLNER, W., O Filho do Homem, a mensagem Político-teológica de Jesus, São Paulo: Paulinas, 1987, p. 128.

${ }^{360}$ BAILLY, A., Le Grand Bailly, Dictionnaire Grec Français, Paris: Hachette, 2000, p. 363.

${ }^{361}$ SCHNACKENBURG, R., El Evangelio según San Juan, p. 285.

${ }^{362}$ FEUILLET, A., O Prólogo do Quarto Evangelho, São Paulo: Paulinas, 1971, p. 107. 
realidade de Jesus, um novo compreeender-se a si mesmo no amor de Deus e na revelação da Palavra que se fez carne. Próprio da fé cristológica, se entende como revelação da realidade de Deus ao Filho e do Filho ao crente. A fé que faz ver. A fé que conhece ao ver os sinais, é a resposta à revelação de Deus na Glória de Jesus Cristo que é o Logos encarnado.

Estreitamente relacionado à intimidade do Filho com o Pai está a forma verbal fileN. Com ela o autor quer evidenciar o vínculo de amizade que estabelece uma relação de iguais, motivo da comunhão entre ambos. Sendo o “amor" a característica por excelência de Deus (cf. 1 Jo 4,16) a revelação de que o Filho é o objeto desse amor equivale a dizer que o Pai comunicando esse amor ao Filho com ele se identifica. O Pai ama o Filho desde antes da criação do mundo $(17,24)$ significando que ao demonstrar seu amor ao Filho, comunica-lhe a plenitude de sua glória, o esplendor do seu amor leal $(1,1.14)^{363}$. A glória-amor leal identifica-se com a verdade da experiência que está sendo comunicada aos homens pela "Palavra que se fez carne" $(1,14)$.

O uso do termo de knumn no NT geralmente significa mostrar no sentido de reclamar a atenção sobre a coisa apresentada. A enunciação "o Pai mostra tudo" sinaliza para a necessidade da comunicação da realidade divina. A forma verbal dejknumin no Evangelho tem o sentido de revelar, desvelar. Como Filho que é, Jesus recebeu do Pai a revelação de sua identidade. É o ato de pôr em evidencia o agir de Jesus por suas obras. $\mathrm{O}$ ato de mostrar é uma indicação que a ação é de Jesus. Assume o significado de revelar: "Mostra-me o Pai" $(14,8 \mathrm{~s})^{364}$.

Sendo o Pai a origem dessa iniciativa, isso requer que sua visibilidade e sua evidência sejam manifestadas, o que causará admiração. O uso que o Evangelho de João faz da forma verbal qaunaz̧W diz respeito à admiração, ao asssombro dos discípulos e dos judeus em geral, à encarnação. Aqui nos versículos 20e e 28a é precisamente um termo para descrever o impacto causado por Jesus com sua atividade $^{365}$.

A gratuidade do agir do Pai vem expressa por meio da forma verbal d dwnin. Digno de particular atenção o conceito aparece no Evangelho de João no sentido

\footnotetext{
${ }^{363}$ Cf. Verbete amor In MATEOS, J.; BARRETO, J., Vocabulário Teológico do Evangelho de São João, São Paulo: Paulinas, 1989, p. 24.

${ }^{364}$ SCHLIER, H., verbete diknunn In KITTEL, G.; FRIEDRICH, G. (Orgs.)., GLNT, v. III, Brescia: Paideia, 1966, p. 809 et seq.

${ }^{365}$ ANNEN, F., verbete qaunazW, In BALZ, H.; SCHNEIDER, G., DENT, p. 1836.
} 
de "dom do Pai ao Filho". Nesse Evangelho Jesus é o grande dom de Deus $(4,10)$. O Filho é o dom por excelência. Deus é o doador. Dar é um aspecto da atividade divina. É uma ação que procede de Deus. Dá tudo ao Filho. Dar é uma expressão joanina para falar da graça de Deus à humanidade: seu próprio Filho $(3,16)$. A ação doadora do Pai adquire força na argumentação, porque manifesta o agir de Deus no Filho como aquele que "faz viver" e "exerce o julgamento"; portanto, que é "Vida" e único "Juiz".

O Pai doa ao Filho seu próprio poder de dar vida, de levantar (egeirw) os mortos (v. 21a-b). A forma verbal egeirw tem o significado fundamental de despertar, estimular, levantar ou em sentido intransitivo de levantar-se, despertarse. Com relativa frequência o imperativo intransitivo egeire se emprega, no NT, para exortar os enfermos a que se levantem e com ele se lhes transmite a cura ou se faz ver que esta acontecerá em um futuro imediato (cf. Jo 5,8; Mc 2,9. 11; 3,3; Lc 5,23. 24; 6,8; Mt 9,5; At 3,6 ${ }^{366}$. Essa forma verbal egeirw aparece no texto (vv. 19-47) apenas uma vez e no sentido de ressuscitar, equivalente de zuppoiej/

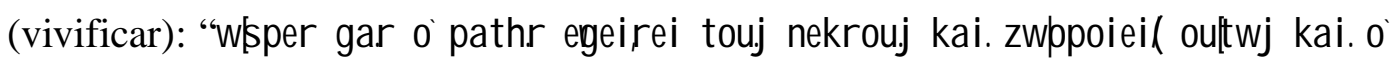
uiòj oull qel é zuppoiè» (v. 21). É significativo que seja referido ao poder do Filho no sentido de ressuscitar porque é o mesmo verbo que Jesus usa, no texto narrativo, para ordenar ao enfermo em 5,8 que se levante. No Evangelho de João, o verbo egeirw se afirma como tendo frequentemente um sentido cristológico específico $\left(2,19.20 ; 14,31\right.$; cf. 11,29; 12, 1. 9; 13,4) ${ }^{367}$.

O texto diz que "O Filho dá a vida a quem quer" (v. 21c), conferindo ao Filho a mesma propriedade divina de dar vida. O termo $\mathrm{ZWh}$,(vida) ${ }^{368}$ no Quarto Evangelho recebe uma significação especial e única. A realização das obras de

\footnotetext{
${ }^{366}$ Este termo aparece quase sempre no NT como sinônimo de axi sthnn (na LXX é comum a equivalência com o hebraico noy). No sentido especial de ressuscitar pessoas mortas o empregam 13 vezes (contra 34 vezes ani șthni) e no sentido de ressurreição escatológica se expressa 20 vezes. Em alguns casos se observa um emprego diferente dos verbos ege rw e ani sthnn. Assim, por exemplo, no NT egeirw aparece 144 vezes e ani sthni 108 vezes, e delas unicamente eger rw, 59 vezes no sentido geral. Cf. KREMER, J., verbete egeirw In BALZ, H.; SCHNEIDER, G., DENT, p. 1127 et seq.

${ }^{367}$ Os termos vivificar-ressuscitar (egèrén - zwopoi ėh) no seu significado compreendem seja a ressurreição corporal, seja aquela espiritual, como aparece no conjunto do discurso que trata de uma e de outra no entrelaçamento da escatologia já presente, a ressurreição espiritual, com a escatologia futura, a ressurreição dos mortos no sepulcro (vv. 24; 25-29). Cf. FERRARO, G., Il Paraclito, Cristo, Il Padre nel Quarto Vangelo, 1996, p. 143.

${ }^{368}$ Nesse texto o termo "vida" se repete nos vv. 24e, 24g, 26a, 26b, 29b, 40b, e no v. 39b na expressão zwhn ai wni on (vida eterna). Além da forma verbal zaw (zhsousin v. 25f) e zuppoi ė/ (vv. 21b, 21c).
} 
Jesus $(5,8)$ são sinais que patenteiam seu poder vivificante: "Eu vim para que tenham a vida e a tenham em abundância" $(10,10)$; "Eu sou a ressurreição e a vida" (11,25). Desde o Prólogo se diz que o I ogo ${ }^{369}$ é Vida (1,4; cf. 10,10; $11,25 \mathrm{~s} ; 20,31)^{370}$. O poder de dar vida, no Prólogo $(1,4)$, está ligado à criação por meio dele: "Meu Pai trabalha até agora, e eu também trabalho" (5,17; cf. vv. 1930). O evangelista fala da vida como luz, o l ogoj é doador de vida, vida que é a luz do mundo, a luz da criação, que é Jesus (cf. 1,4; 8,12). Jesus é a vida $(14,6)^{371}$.

A segunda propriedade divina, a ação de krinw (julgar), está associada ao poder de dar vida. No texto (vv. 19-47) a ação de julgar de Deus se manifesta por meio do substantivo krișij e da forma verbal krinw. Neste texto eles são recorrentes: o primeiro, nos vv. 22b. 24f, 27a, 29c, 30c, e o segundo nos vv. 22a, $30 b^{372}$. O texto aqui afirma que o juízo se realiza desde o momento em que o Pai enviou seu Filho ao mundo e confiou-lhe todo julgamento (v. 22b). O Filho, portanto, dispõe da vida e do julgamento (vv. 21c; 22b). O Pai comunica não

\footnotetext{
${ }^{369} \mathrm{O}$ termo I ogoj é usado frequentemente na LXX e quase sempre traduz o termo hebraico rbD'(ou o seu equivalente arameu hLn'n um termo cujo conteúdo semântico coincide em parte com o do I ogoj, porém que não é totalmente idêntico. Deriva da raiz rbd, que significa falar, e rbđ̄'é essencialmente a palavra falada como meio de comunicação. E este uso de l ogoj como tradução de rbJ' inevitavelmente influenciou no sentido como o l ogoj foi compreendido. No AT humyrbD se usa frequentemente para designar a comunicação de Deus com os homens, a revelação de si mesmo, especialmente por meio dos profetas, aos quais "vem a Palavra do Senhor". A totalidade da revelação de Deus se denomina hr'AT, termo que frequentemente é paralelo ou virtualmente sinônimo de hubyrblbD Não se pode atribuir, portanto, ao espírito grego, a paternidade da idéia joanina do I ogoj, no sentido de Palavra como revelação de Deus, convém buscá-la em outras formas de expressão bíblica no AT. Cf. Verbete I ogoj, In FREEDMAN, D. N., (Ed.), The Anchor Bible Dictionary, New York: Bantam Doubleday Dell Publishing Group, 1992, p. 349 et seq.

${ }^{370}$ Como em outras religiões antigas o conceito de "vida" se usa no cristianismo primitivo para designar a salvação. É comum ao AT, ao judaísmo e ao cristianismo a expressão "o Deus vivo". Esse conceito adquire diversos matizes, como por exemplo, "o que existe" em contraste com os ídolos mortos, isto é, com os outros deuses (cf. 1 Ts 1,9). No AT, especialmente nos Sapienciais, o conceito está relacionado com a Criação. Em comum com o judaísmo de pensamento apocalíptico, que espera uma ressurreição, o cristianismo tem a esperança da zwhn ai uni on (vida eterna). Conceitos como árvore da vida, água da vida, livro da vida se acham extensamente difundidos e atestados nas religiões do mundo antigo. Cf. SCHOTTROFF, L., verbete ZWh, In BALZ, H.; SCHNEIDER, G., DENT, p. 1745.

${ }^{371}$ Cf. A luz e a vida são conceitos intercambiáveis no Prólogo, no qual a vida era a luz dos homens, triunfando das trevas por sua própria intensidade, porém requerendo acolhimento por parte deles. Assim também "a vida" que o Filho revela expõe uma opção. Cf. LÉON-DUFOUR, X., Leitura do Evangelho segundo João, p. 61.

${ }^{372}$ A experiência histórica do povo de Israel proporciona aos crentes exemplos concretos desse juízo divino, ao qual estão submetidos todos os homens e todos os povos (o êxodo, o exílio etc.). Lembrar o juízo ameaçador, anunciar sua realização próxima faz parte dos temas proféticos essenciais (Is 3,13ss; Am 5,18ss; Ez 16,38; Jr 25,30-38). Nos profetas pós-exílicos, cujos modos de expressão evoluem para a apocalíptica, a evocação de um juízo final, englobando os pecadores do mundo inteiro e todas as coletividades hostis a Deus e a seu povo, constitui o prelúdio obrigatório dos oráculos de "salvação" (cf. Is 66,16; Jl 4,12; Dn 7,9-12. 26). A escatologia aí transcende o mundo e a história. O mesmo acontece no livro da Sabedoria (Sb 4,20-5,23). Cf. LÉON-DUFOUR, X., Vocabulário de Teologia Bíblica, Petrópolis: Vozes, 1977, pp. 492-493.
} 
somente a própria vida ao Filho, como as faculdades de dar vida (vv. 21. 26) e de julgar (vv. 22b; 30). A fé no julgamento de Deus é um dado fundamental que jamais se põe em dúvida ${ }^{373}$, mas aqui está acrescido do critério da dependência da fé no Filho. Quem não dá adesão a Jesus está sujeito a juízo, será chamado a julgamento (v. 24).

Com o verbo penpw o autor quer chamar a atenção para a iniciativa da missão que procede do Pai e permanece presente na obra do Filho ${ }^{374}$. O léxico penpw no sentido de enviar pode ser considerado um termo joanino ${ }^{375}$, pois das 79 ocorrências no Novo Testamento, 32 correspondem ao Evangelho de João e, em 21 delas, se fala de Jesus como "enviado". Essas 32 passagens e os enunciados, construídos em terceira pessoa, acerca do Pai ou de Deus "que o enviou" (v. 23e; 7,18), permitem reconhecer o teocentrismo cristológico da relação entre o Pai e o Filho.

No texto de 5,19-47 o ato de enviar aparece alternado em duas formas verbais: com o verbo penpw aparecendo nos versículos 23e, 24d, 30e, 37a, (sempre no particípio aoristo - ação concluída, definitiva - 4 vezes) e, na forma verbal apostel I w nos versículos 33a, 36f, 38b (só no indicativo para indicar que é uma ação que concretiza a missão - 3 vezes). É significativo que nesse texto tal vocábulo só apareça em formas verbais e nunca como substantivo. A realidade histórica do envio do Filho pelo Pai se expressa nos lábios de Jesus mediante a fórmula o’ penyaj ne (nesse texto nos vv. 24d. 30e. 37a) ${ }^{376}$.

Quando se fala da finalidade que persegue o envio de Jesus e de sua função como revelador e redentor, o autor prefere o termo apostel I e $\mathrm{n}^{377}$. O emprego dos verbos revela um liame constante entre o envio de Jesus por parte do Pai de

\footnotetext{
${ }^{373}$ No Novo Testamento, nos Evangelhos Sinóticos, a pregação de Jesus se refere frequentemente ao julgamento do último dia. Todos os homens deverão prestar contas. A motivação principal do juízo divino é a atitude tomada pelos homens frente ao Evangelho (cf. Mt 25,14-30).

${ }^{374} \mathrm{O}$ tema da mediação, por meio de um enviado, vem da tradição teológica do Livro do Êxodo, de Moisés, o enviado em "Nome de YHWH" para libertar os hebreus cativos no Egito (cf. Ex 3,47,12). Cf. RITT, H., verbete penpw In BALZ, H.; SCHNEIDER, G., DENT, p. 872 et seq.

${ }^{375} \mathrm{O}$ verbo penpw é usado concretamente para expressar uma comunicação humana, que se dá pelo envio de pessoas para comunicar mensagens quase sempre muito importantes. Cf. BAILLY, A., verbete penpw In Le Grand Bailly, p. 1510.

${ }^{376}$ E no Evangelho: 4,34; 6,38. 39. 44. 49; 7,16. 28. 33; 8, 16. 18. 26. 29; 9,4; 12,44. 45. 49; 13,20; 14,$24 ; 15,21 ; 16,5$. Mas a forma mais usada (17 vezes) é o particípio aoristo òpenyaj $\mathrm{n}$ (v. 37a)

377 Também no Evangelho o uso de aposte I w, especialmente, em 6,29; 8,42; 10,36; 17,3 (ao todo 15 vezes). Para o envio de pessoas humanas o Evangelho usa em seis casos apostel I w 1,19. 24; 5,33; 7,32; 11,3; 18,24 e uma só vez penpw em 1,22. Cf. SCHNACKENBURG, R., El Evangelio según San Juan, p. 146.
} 
um lado e a exigência para os homens crer no enviado de outra parte ${ }^{378}$. No v. 36 o Pai é o sujeito do verbo apostel I w. Ele retorna àquele que o enviou ao mundo $(7,33 ; 16,5.28)$.

O verbo ti nay $w^{379}$ expressa a síntese dos argumentos desse primeiro motivo que ocorre quatro vezes consecutivas (vv. 23a, 23b, 23c, 23d). O sentido é que se reconheça a autoridade especificamente divina do Filho, conferida pelo Pai, ao delegar-lhe a atividade de julgar: "Pois o Pai a ninguém julga, mas confiou ao Filho todo julgamento" (v. 22b). Se o Pai deve ser honrado, essa obediência se requer, também, em relação ao Filho, pois "todos devem honrar o Filho como honram o Pai", uma vez que já foi afirmada a declaração de igualdade de ação do Pai e do Filho no início do discurso (vv. 19e-f-g). Como as palavras e as obras do Filho são as palavras e as obras do Pai, então a fé colocada no Filho é colocada no Pai que o enviou ${ }^{380}$. O discurso insiste em um envio-missão do Filho por meio da forma "o enviado do Pai". É um atributo, uma qualificação essencial referida à atividade salvífica histórica de Jesus de forma que a revelação do Pai se encontra fortemente fundada no seu envio. Por esse motivo, o "enviado" revelador do Pai

\footnotetext{
${ }^{378}$ JONGE, M., Les verbes apostel I $w$ et penpw dans le vocabulaire théologique de saint Jean In JONGE, M., L'Évangile de Jean, sources, rédaction, théologie, Belgique: Leuven University Press, 1977, p. 385-388.

${ }^{379}$ Esse termo aparece seis vezes no Evangelho de João. Cf. HÜBNER, H., verbete ti naw In BALZ, H.; SCHNEIDER, G., DENT, p. 1751.

${ }^{380}$ Jesus, em sua vida terrena, se entendeu a si mesmo como tendo sido enviado por Deus para levar a cabo uma tarefa profética e uma missão específica, centrada no anúncio do Reino (cf. Mt 10,40; 15,24; Mc 2,17b; Lc10,16). Se a parábola de Mc 12,1-9 for autêntica, Jesus comparou sua missão a de um enviado de Deus. Tem, pois, certa base no Jesus histórico o desenvolvimento póspascal de uma cristologia do envio. Paulo dá o primeiro passo: Gl 4,4 apresenta traços da fórmula de envio: Deus, o sujeito; o verbo de envio; Filho como o complemento. O que no Jesus terreno é uma experiência existencial de sua relação com o Pai, se transforma nos Evangelhos da infância em uma concepção virginal por meio do Espírito. Mateus e Lucas retroagem à filiação, ao momento da concepção. Porém tenhamos em conta que não se trata de uma afirmação histórica, mas de uma confissão de fé cristológica: Jesus, o grande dom de Deus para a humanidade, em forma narrativa. Nesses relatos se indica a iniciativa divina mediante fórmulas de envio. Ver a presença do verbo "baixar ou descer" em Lc 1,35. Sem dúvida alguma, as tradições primitivas da comunidade joanina deviam ter afirmações que remontavam a Jesus e que falavam do envio como uma missão histórica e profética. Ecos dessas tradições se encontram em textos que se interpretam desde os últimos estratos da tradição joânica, embora permitam uma leitura diferente (3,16-17). A evolução dessas tradições antigas, impulsionadas pelo desdobramento da comunidade do judaísmo, vai recobrir essas afirmações de um significado no qual o funcional ou histórico passa para um segundo plano, para transformar-se em textos que nos falam da pré-existência de Jesus. L. Martin fala de um caminho mental, desde uma cristologia profético-mosaica a afirmações de alta cristologia. Cf. RITT, H., Verbete penpw In BALZ, H.; SCHNEIDER, G., DENT, p. 872 et seq.
} 
merece as mesmas honras que são dadas a Deus mesmo (vv. 23-24). Não se obtém a salvação senão acolhendo o enviado enquanto tal (v. 24; cf. 17,3) ${ }^{381}$.

\subsection{2.}

A semântica do segundo motivo (v. 24)

A memória semântica da Palavra de Deus manifestada por suas obras, especialmente na criação, e proclamada por meio de um "enviado" abrange as proposições do segundo motivo. A obra criadora de Deus se realizou por sua Palavra $(\mathrm{Gn} \mathrm{1})^{382}$. O incessante trabalho de Deus é dar e manter a vida (vv. 21a21b). O Pai dá a vida e o mesmo faz o Filho por sua Palavra. O vocábulo "I ogg " no Prólogo é o elemento revelador da pessoa do Filho (o`l ogoj sarx egeneto, cf. $1,14)^{383}$. O que o Evangelho de João afirma no Prólogo é precisamente que a "Palavra" atemporal (En arch" se fez acontecimento (sarx egeneto). No Novo Testamento o caráter e pessoa do I ogoj cristão brotou da genuína confissão cristã do Jesus, vindo historicamente como I ogoj-Cristo, e só dela pode surgir com tal claridade $^{384}$. Na realidade, se desenvolveu já no AT uma teologia da Palavra de Deus que parte do relato da criação e do fato da revelação e através de peças

${ }^{381}$ JONGE, M., Les verbes aposte I $\mathrm{w}$ \& penpw dans le vocabulaire théologique de saint Jean In JONGE, M., L'Évangile de Jean sources, rédaction, théologie, p. 389.

${ }^{382}$ Foi, sobretudo, a história da criação que sugeriu uma personificação da Palavra de Deus como potência criadora, o que no mundo helenístico, mesmo fazendo-se abstração da tradução costumeira (rhha), deixava-se combinar muito bem com as opiniões corriqueiras a respeito do I ogoj. No Prólogo Joanino isso chegou a uma aplicação cristológica. Nas traduções da Bíblia para o aramaico, "a Palavra" (memrá) representa, surpreendentemente, o próprio Deus. Mas não houve muita especulação judaica sobre "a Palavra", possivelmente porque a vontade de Deus era encontrada primeiramente na Torá; e não se insistia muito na "Palavra do Senhor", porque esta expressão aparece, sobretudo, nos textos proféticos, isto é, em textos de grau secundário de revelação, se comparados à Torá. Cf. MAIER, J., Entre os dois Testamentos, História e religião na época do Segundo Templo, São Paulo: Loyola, 2005, p. 219.

${ }^{383}$ A teologia da Palavra de Deus na criação (Gn 1), na boca dos profetas (cf. Is 40,5-8; 55, 9-11; Jr 1,4. 11; 2,1, etc.) e na Lei (cf. Sl 119, 38. 41. 105, etc.) tem múltiplas funções que facilmente se podem comparar com as afirmações sobre o I ogoj Joanino; porém não autorizam a derivar exclusivamente dela a doutrina joanina do logoj ainda que possa haver influído nesta mediatamente através da Sabedoria e da especulação sobre a Torah. Cf. Verbete I ogoj, FREEDMAN, D. N., (ed.)., The Anchor Bible Dictionary, p. 349 et seq.

${ }^{384}$ No Novo Testamento, a Palavra de Deus é com muita frequência a própria mensagem da salvação, isto é, o Evangelho, ou a boa Notícia (veja-se, por exemplo, Lc 8,11; 2 Tm 2,9; Ap 1,9; cf. especialmente 1 Jo 1,1) proclamada por Paulo (At 13,5; 1 Ts 2,13), pelos demais apóstolos (At 6,2) e pelo próprio Jesus (Lc 5,1; Mc 2,2; e outras muitas passagens). Porém, o Evangelho que Paulo proclamava era a pessoa mesma de Cristo (cf. 1 Cor 1,23; 2 Cor 4,1-6; Gl 3,1); e o mesmo se pode dizer dos demais apóstolos (cf. At 2,36; 4,12). Por outra parte, no entanto, os Evangelhos Sinóticos têm razão ao sugerir que Jesus anunciou a chegada do Reino de Deus (Mt 13,19). João representa o verdadeiro núcleo da mensagem de Jesus, centrado na própria pessoa do portador da salvação. Cf. BARRET, C. K., El Evangelio según San Juan, Madrid: Cristiandad, 2003, p. 232. 
poéticas conduz à literatura sapiencial do judaísmo tardio ${ }^{385}$. Toda a idéia de revelação no AT está determinada pela analogia da Palavra falada e escutada, enquanto distinta da idéia de revelação como visão ${ }^{386}$. Para o hebreu, a palavra, uma vez pronunciada, tem por si mesma uma espécie de existência substantiva (cf. Is 55,10-11; Sb 18,15-16) ${ }^{387}$. Do mesmo modo, no Prólogo de João se pensa na criação e na revelação; e o resto do Evangelho leva a supor que aqui se pode encontrar uma influência do AT.

Nesse texto, de modo explícito, se afirma que a "Palavra" do Enviado do Pai tem poder vivificante (vv. 24c; 24g) e se expressa por suas obras (cf. 5,8) ${ }^{388}$. O ton I ogon nou (a minha palavra), diz o Filho, é uma revelação que traz vida (v. 24b) aos que a escutam e a aceitam na fé (vv. 21; 24; 25-26; 28-29a). A Palavra, mediante a qual o enviado exprime a si mesmo, permite "ao ouvinte" o reconhecimento de sua eficácia e a entrada em relação com ele através do "dom da vida".

Por isso, o verbo aka@ adquire particular relevo no NT, significando não só a ação de ouvir, como também, em sentido mais amplo, inteirar-se, assimilar o que se ouve, prestar-lhe obediência ${ }^{389}$. Os sujeitos de akoum são, de maneira inteiramente predominante, pessoas, sobretudo porque "o ouvir" é a forma essencial de assimilação na religião bíblica: ouvir a Palavra (cf. Dt 6,4; 1 Cor 9, 16; Rm 10,14; Ap 2-3). No v. 24b esse verbo aparece em sentido absoluto, acentuando o pôr em prática a palavra do enviado: "Quem escuta a minha palavra

\footnotetext{
385 A tardia teologia judaica comparada com o AT preferiu outros conceitos para designar a "Palavra de Deus", sem, contudo, deixar de continuar falando desta Palavra, como acontece em Sb $9,1 \mathrm{~s}$, que ressalta a afinidade existente entre Palavra de Deus e Sabedoria ${ }^{385}$. Assim o conceito judeu de Sabedoria (hnkx) proporciona uma linha de interpretação muito importante do I ogoj Joanino. Já no livro dos Provérbios (cf. Pr 8,22ss) a Sabedoria possui uma existência independente com respeito a Deus uma vez que inclui uma relação com o mundo criado. Nos livros sapienciais posteriores a Sabedoria vai se convertendo progressivamente em um ser pessoal ao lado de Deus e frente ao mundo criado. Os textos de $\mathrm{Sb}$ 7,22 ("Pois a Sabedoria artífice de tudo mo ensinou!") e 7,27 (... entrando nas almas boas de cada geração, delas faz amigos de Deus e profetas) ilustram a dupla função, cosmológica e soteriológica, da Sabedoria. Cf. SCHNACKENBURG, R., El Evangelio según San Juan, p. 297-298.

${ }^{386}$ DODD, C. H., Interpretación del Cuarto Evangelio, Madrid: Cristiandad, 2004, p. 308.

${ }^{387}$ Muito embora possa ser mera figura de linguagem, deve admitir-se, sem dúvida, que a facilidade para usar tal linguagem aponta a uma tendência habitual do pensamento a atribuir à palavra falada uma existência e uma atividade por si mesma; e de fato tal tendência está profundamente impressa na língua hebraica: a palavra é enviada, vem, vai, permanece (cf. Is 40,8). Ibid., p. 308.

${ }^{388}$ O Evangelho, desde o início, assume que a Palavra de Deus se fez carne (cf. 1,14) e que a "graça e a verdade" de Deus vieram por Jesus Cristo, cuja palavra vivifica (cf. 4,50).

${ }^{389}$ Cf. SCHNEIDER, G., verbete akouw In BALZ, H.; SCHNEIDER, G., DENT, p. 155 et seq.
} 
e crê naquele que me enviou tem a vida eterna" ${ }^{390}$. No Evangelho de João deve interpretar-se no sentido de ouvir e aceitar com "fé" o que se ouve, isto é, escutar com obediência a Jesus.

Essa fé evita que se sofra o julgamento, pois quem o ouve e o aceita não vem a juízo (v. 24f), porque ouve e aceita o Pai. A palavra do enviado - que não é senão a palavra vivificante de Deus - tem em si a potência de conferir aos crentes a vida eterna (v. 24c; cf. 6,63. 68) ${ }^{391}$. A passagem da morte para a vida ocorre a partir do momento em que a Palavra de Deus é acolhida na fé, e seu efeito permanece, como o indica o tempo perfeito do verbo "nÆtabedhken" "392. A fé confiante implica numa entrega completa de si mesmo ao enviado de Deus, seu representante legítimo, cuja Palavra exala confiança no perdão divino. E isto exige boa vontade da pessoa que a escuta para fazer a opção. Por conseguinte, a aceitação resoluta equivale a passar da morte à vida (v. $24 \mathrm{~g})$.

O vocábulo pisteun (crer) é a terminologia usada pelo quarto evangelista para do ato de crer em Jesus, "o Filho". Com ela quer expressar a dinâmica da atitude do crente. Falar da "fé" tem importância capital no Evangelho ${ }^{393}$ e sempre se relaciona com a "escuta da palavra" de Jesus: "Quem escuta minha palavra e crê" (vv. 24b-24c). Com frequência pensa, não tanto na existência da fé, mas na vitalidade ou intensidade da mesma. Para o evangelista o ato de "crer" se qualifica como o ato que coloca o crente em relação imediata com a pessoa de Jesus e com o seu mistério ${ }^{394}$. "Quem crê em mim, não é em mim que crê, mas naquele que

\footnotetext{
${ }^{390}$ Porém, não em todas as passagens se faz esta distinção entre o ouvir e o aceitar com fé o que se ouve. Algumas vezes a linguagem torna-se ambígua como nos versículos 25 e 28 . Aí fala-se de ouvir a voz (com genitivo, o que é raro). A forma verbal akoûn aparece na seção 25-30 quatro vezes (vv. 25d, 25e, 28d, 30b). Cf. SCHNEIDER, G., verbete akoum In BALZ, H.; SCHNEIDER, G., op. cit. p. 155 et seq.

${ }^{391}$ Segundo Tuñi, a insistência do Jesus Joanino ser apresentado como o revelador insiste especialmente na importância de ser aplicado a ele o termo "palavra" como um termo de revelação. A palavra do enviado alcança o ápice da potência da palavra. Já no presente, pela escuta da palavra, se pode passar da morte para a vida sem vir a juízo. (cf. 3,15-18. 36; 6,40. 47; 12,46s). Cf. TUÑI VANCELS, O. J., O testemunho do Evangelho de João, pp. 88-95.

${ }^{392}$ Cf. LÉON-DUFOUR, X., Leitura do Evangelho segundo João, p. 45.

${ }^{393}$ Em João o verbo pi steên aparece 98 vezes no Evangelho e nove na primeira carta de João. Somente em 1 Jo 5,4 aparece o substantivo pistij. No sentido profano tem o sentido de dar crédito a uma mensagem ou a quem traz a mensagem; no sentido religioso pode adquirir, segundo o contexto, o significado mais de considerar verdadeiro, obedecer ou confiar. Referido à pessoa é o que é fiel, pessoa de confiança. Cf. BARTH, G., verbete pistenm In BALZ, H.; SCHNEIDER, G., DENT, p. 945 et seq.

${ }^{394}$ Ainda que não se possa supor um ponto de partida da existência de um conceito uniforme da fé que tenha havido no começo da evolução neotestamentária e que logo houvesse se desenvolvido de diversas maneiras, sem dúvida na ampla maioria dos níveis e dos escritos do NT pode observarse a existência de uma maneira de falar que se distingue claramente da do mundo do AT e do
} 
me enviou" $(12,44)$. Crer significa ver o Jesus da história (sarx), mas neste ver também entrever a "Glória" (dimensão pós-pascal). O crer joanino não é somente ter por verdadeiro um fato, mas também descobri-lo em profundidade, interpretálo e atualizá-lo.

Dentre as características da fé neotestamentária, se destaca o fato de ser só no NT que a fé chega a ser a designação central e sintetizadora da relação do indivíduo com Deus e de que especialmente a fé se encontra, agora, em relação indissolúvel com Jesus, como o Senhor - crucificado e exaltado - da comunidade. A fé joanina tem um tom de relação pessoal muito marcado ${ }^{395}$. Sem dúvida essa fé está submetida a duras críticas no Evangelho pelo contexto de tensão (Jesus escandaliza: 2,18; 5,18; provoca divisão: 7,43; 9,16; 10,19; murmuração: 6,41; ódio e perseguição $7,30.44 ; 8,20$ ), e todo o Evangelho pode ser lido, tendo como ponto de referência a reação de aceitação perante Jesus $(2,11 ; 2,23 ; 4,39 ; 4,53$; $6,69 ; 8,30.31 ; 9,38 ; 12,42 ; 20,30-31)$. A fé é, portanto, uma resposta à revelação de Jesus, exemplificada nos discípulos: 17,6-8. A Fé no Filho que o Pai enviou e que fala as palavras de Deus é a condição para se atingir a Vida Eterna (v. 24).

A categoria com a qual João indica a salvação é a vida - Vida Divina - não só por ser Dom de Deus, mas comunhão com a própria vida de Deus - zWh, ai whi on - Vida eterna, não porque fosse dada no último dia, mas porque é do mundo de Deus ${ }^{396}$. Vida Eterna deve ser entendida não como prolongamento matematicamente infinito desta vida, mas como momento novo que vem substituir este tempo desgastado, "este mundo". É um salto qualitativo que começa já na fé e na escuta da Palavra do Filho enviado. O evangelista substitui o conceito "Reino

\footnotetext{
judaísmo, e que neste ponto, precisamente, mostra certa continuidade e coincidência. Cf. BARTH, G., verbete pistem In BALZ, H. ; SCHNEIDER, G., op. cit., p. 956 et seq.

${ }^{395}$ A vinculação da fé com Jesus se expressa quase sempre com palavras que falam de crer nele: pisteuv ej auton: 2,$11 ; 3,16.18 .36 ; 4,39 ; 6,40 ; 7,5.31 .39 ; 8,30 ; 9,35 \mathrm{~s} ; 10,42 ; 11,45.48 ; 12,11$. 17. 38. 42; 12; pistuen en autou/ 3,15 ; no Filho do Homem: 9,35. 38; gai stente ah exoi : 5,46; 6,$35 ; 7,38 ; 10,38$ 11,25. 26; 12,44. 46; 14,1. 12; 16,9; 17,20; ex tw/ ononati 1,12 (em seu nome); 2,23; 3,18; pi steuv ej $\square 5,47$ (nas Escrituras). Acentua-se que a fé está ligada à palavra de Jesus ou ao testemunho acerca de Jesus $(5,24.47 ; 1,7 ; 4,39$. 41s. 50; 8,30s; 17,20; cf. 3,16. 27; 18,37). Semelhante fé se orienta até nos enunciados de que Jesus havia sido enviado pelo Pai $(5,24$. 38; 6,29; 12,44; 17,8. 21), tinha saído do Pai $(16,28)$ e está no Pai e o Pai nele $(14,10 \mathrm{~s})$. Cf. BARTH, G., verbete pi stean In BALZ, H.; SCHNEIDER, G., op. cit., p. 945 et seq.

${ }^{396}$ SASSE, H., verbete ai wn In KITTEL, G.; FRIEDRICH, G. (Orgs.), GLNT, v. III, Brescia: Paideia, 1966, p. 562.
} 
de Deus" por Vida Eterna ${ }^{397}$ : Vida que vivemos na opção de fé assumida diante da Palavra e da prática de Jesus. É o exercício da vontade de Deus, desde já - ou seja, aquilo que o reinado de Deus profundamente significa. "Quem crê em Jesus vive aquilo que condiz com Deus, o que é definitivamente válido enquanto for fiel" (v. 24).

\subsection{3.}

\section{A semântica do terceiro motivo (vv. 25-29)}

O fundamento da comunicação da chegada da wFa (hora) se radica na temática do envio. O poder de vivificar comunicado ao enviado (vv. 21 e 24) é dom para crentes, pois este poder lhes permite comunicar a vida aos que creem, dom que se estende, também, aos mortos, na chegada da wFa. A expressão kai .nuh extin (e é agora) exclui que Jesus esteja apenas anunciando o julgamento como próximo. O "nuh" tem o sentido forte de "desde já"398. A W[a (hora) de Jesus é uma concepção importante no Quarto Evangelho, que lhe atribui um significado riquíssimo. A hora é o momento em que se realiza um acontecimento determinado por Deus. A hora da manifestação da glória do Filho único do Pai, sobretudo, de sua paixão que leva a termo o desdobramento do plano salvador de Deus (Jo 2,4; 13,1). Não é tanto um momento preciso do tempo, quanto o conjunto de sua atividade que ela coroa, como sucede com a hora da mulher, cujas dores marcam o surgimento duma nova vida (Jo 16,21) ${ }^{399}$. Aqui sugere uma ligação com a sua manifestação messiânica ilustrando outro aspecto mais profundo da paixão: sua hora é o tempo de glorificação, como é chamada em João $(12,23 ; 17,1)$. Mas, é mais ainda a "hora" de Deus, fixada por ele apenas, e vivida por Jesus, segundo a vontade do Pai (v. 30e; cf. Jo 4,34-36). Tendo vindo para fazer essa vontade (v. 30e), ele aceita essa "hora", apesar da angústia que ela lhe causa (Jo 12,27): não é ela também a hora de sua glória (Jo 12,23) e de sua atividade salvífica (Jo 12,24)?

\footnotetext{
${ }^{397}$ No Novo Testamento Cristologia e Escatologia são inseparáveis, pois o Cristo/Messias deve inaugurar o tempo do fim, o reinado de Deus no mundo, tempo de paz e de plenitude - depois de vencidos os inimigos. Cf. LÉON-DUFOUR, X., Vocabulário de Teologia Bíblica, p. 366.

${ }^{398}$ Cf. KÖNINGS, J., Evangelho segundo João, Amor e fidelidade, Petrópolis: Vozes/Sinodal, 2005, p. 140.

${ }^{399}$ A hora em João também valoriza certos acontecimentos (1,39; 4,7). Cf. GIESEN, H., verbete wra In BALZ, H.; SCHNEIDER, G., DENT, p. 2199.
} 
Essa hora significa também juízo para o mundo (Jo 12,31). A hora é explicitamente a hora que Jesus parte deste mundo para o Pai (Jo 13,1 ${ }^{400}$. Porque a Morte e Ressurreição de Cristo foram a manifestação clara desta vida de Deus que, no dom da vida, supera a morte. A eternidade já está aberta, antecipada. Já agora, mas não nega o ainda não. João vê prefigurada em Cristo esta tensão: Hora - Glória, que só se manifesta na cruz $\rightarrow$ Ressurreição. Cristo Opera a Vida: a salvação. João insiste mais na salvação presente do que na consumação futura. $\mathrm{O}$ tempo do agora é rico. É hora de ouvir "a voz do Filho de Deus”. Segundo João, o próprio Jesus a chama uma vez "a minha hora" (Jo 2,4, hora de um acontecimento salvífico, que é revelação para os discípulos: um maior conhecimento do Pai), a tal ponto que ele faz sua esta vontade de Deus ${ }^{401}$. A Encarnação se prolonga e abre agora seu significado de Revelação e salvação (Tempo da Igreja).

De maneira menos espetacular, há o anúncio de outra "hora": ofi ercetai wFa - a "hora escatológica" (v. 28b), a hora que vem com Jesus. Haverá uma "hora" definitiva, a da consumação: é a "hora escatológica" (cf. Dn 8,17. 19). É num tal clima que Jesus anuncia a hora do triunfo final do "Filho do Homem". Hora plenamente desconhecida pelos humanos, é a hora do justo juízo, da colheita (v. 28b; Mt 24,36. 44. 50) ${ }^{402}$.

Essa hora é a da manifestação da exousia (autoridade) concedida pelo Pai ao Filho. O termo exousia indica antes de tudo o direito, o poder, a permissão e a liberdade em sentido jurídico e político, e, como consequência, a permissão ou direito dado por Deus ${ }^{403}$. É o Pai quem protege e apoia a atividade reveladora e salvífica de Jesus sobre a terra, já que deu ao Filho ter vida em si mesmo (v. 26a) e a exousia para julgar (v. 27a). Nos evangelhos é qualidade própria de Deus que se manifesta na capacidade de agir livre e eficazmente sobre pessoas, instituições

\footnotetext{
${ }^{400}$ MONLOUBOU, L.; DU BUIT, F. M., DBU, Petrópolis: Vozes, 2003, p. 363.

${ }^{401}$ Cf. LÉON-DUFOUR, X., VTB, p. 413.

${ }^{402} \mathrm{Na}$ Bíblia a divisão do tempo, em dia e hora, transcende muitas vezes a acepção cronológica e oferece um significado religioso. Assim, como o tempo da "visita de YHWH", ou o "dia da salvação", também a "hora" assinala etapas decisivas do "plano de Deus". A apocalíptica judaica, convencida da proximidade dos últimos tempos, "os da plenitude", divide o tempo previsto em dias e em horas; todos os instantes contam quando chega o fim: "Pois o tempo corre pelas horas" (Dn 11,35).

Cf. GIESEN, H., verbete wra In BALZ, H.; SCHNEIDER, G., DENT, p. 2199.

${ }^{403}$ Quando denota a potência divina ou o poder divino, expressa a absoluta soberania de Deus, cuja palavra é potência, poder; nos escritos mais antigos, esta noção era formulada como estar nas mãos de alguém (cf. 2 Sm 24,14; 1 Cr 29,12s). Cf. MATEOS, J.; CAMACHO, F., Evangelho Figuras \& símbolos, São Paulo: Paulinas, 1992, p. 134.
} 
ou objetos: "liberdade para" fazer ou dispor de algo; é, portanto, autoridade conferida pelo soberano.

O tempo presente obriga a fazer uma krișij: juízo não como fato futuro e externo, mas que se realiza no presente da história, pelo Filho do Homem (v. 27b). Sublinha o presente da escatologia sem negar o futuro. Ressurreição de vida ou de julgamento-condenação (v. 29; 3,18). A eternidade é, pois, antecipada no seu aspecto de prêmio ou condenação (vv. 25-29). Julgar, fazer um juízo, significa discernir ou fazer justiça: "justo julgamento" (v. 30; 9,39) ${ }^{404}$. Cada opção pró ou contra Cristo é um juízo de vida ou de morte. Julgar ou salvar (v. 34c; 3,17; 12,47). O julgamento ( $\mathrm{krissij})^{405}$ já é um fato, constantemente presente, do qual já não se espera, senão, a consumação final. O Evangelho de João desenvolve essa teologia, insistindo na efetivação atual do juízo em plena história, desde os tempos de Jesus.

Porém, não ignora que Jesus, como “ui òj anqrupou’ (v. 27b), foi, pelo Pai, constituído juiz para uma ressurreição de julgamento escatológico (vv. 28-29; do último dia, cf. 6,40). A função judicial escatológica do Filho, divinamente delegada, é manifestada pela expressão "ui òj anqrupou” (Filho do Homem) ${ }^{406}$. O ambiente semântico da escatologia judaica de cunho apocalíptico professava a fé na ressurreição do último dia (Dn 12,2; 2 Mc 7,14). Nos Evangelhos se emprega sempre como uma designação com a qual Jesus se apresenta a si mesmo, e tem o sentido de um título cristológico, portador de uma revelação. Marcos (2,1-13) apresenta o "Filho do Homem" como aquele que exerce a função própria de Deus, ocupando seu lugar na terra. Isso é efeito da posse da "exousia”, que é, portanto, autoridade divina ${ }^{407}$.

\footnotetext{
${ }^{404}$ MATEOS, J.; BARRETO, J., Vocabulário Teológico do Evangelho de São João, verbete Amor, p. 156.

${ }^{405}$ Ibid., p. 157 et seq.

${ }^{406}$ É como "Filho do Homem" que o "Filho de Deus" exercerá o poder de julgar (5,27a e 27b). Em João a expressão Filho do Homem está associada à glorificação, pois a cruz se confunde com a volta ao céu do Filho do Homem, para constituir a sua elevação: "É preciso que seja elevado o Filho do Homem" (3,14s; 12,34); aí está paradoxalmente a sua glorificação $(12,23 ; 13,31)$, e é por ela que se faz a revelação completa de seu mistério: "Então sabereis que Eu Sou" $(8,28)$. Compreende-se que, por antecipação dessa glória final, o Filho do Homem exerce desde já certos poderes seus: notadamente julgar e vivificar os homens $(5,21 \mathrm{~s}$. $25 \mathrm{ss})$. Cf. LÉON-DUFOUR, X., $V T B$, p. 366.

${ }^{407}$ Cf. MATEOS, J.; CAMACHO, F., Evangelho. Figuras \& símbolos, 1992, p. 134.
} 
No Evangelho de João quase todas as passagens que trazem a expressão "Filho do Homem" se referem à atividade terrena de Jesus ${ }^{408}$. As sentenças acentuam a pretensão de Jesus possuir plena autoridade e majestade. É a única vez que uiòj anqrupou aparece ao lado de tw/ ui ẁ/(v. 26b). No v. 27b existe uma óbvia alusão a Dn 7,13. É a única vez em todo Novo Testamento que não aparece o artigo $^{409}$ diante de nenhum dos dois substantivos; assim também no texto grego de Dn 7,13 que não tem artigo ${ }^{410}$. A forma e o conteúdo do lógion joanino que estabelece essa ligação, também apresenta uma diferença para além da dúvida: A exousia que vem explicitamente conferida por Deus ao Filho (v. 27a), não está claro em Dn 7,13, nem tão pouco ao Filho do Homem de Daniel é concedida a função de salvar. É decisiva em João a conexão da expressão ui òj anqrupou com a pré-existência e a encarnação, assim como o retorno ao mundo celestial, porém de tal maneira, que tudo se concentre no Jesus terreno $(3,13)$, o crucificado e ressuscitado, que é o exaltado e glorificado. Em sua vida e em sua morte acontece a revelação escatológica de Deus: a plena realização da salvação ${ }^{411}$.

Logo no início do Evangelho João combina, ao mesmo tempo, no texto de 1,34-51 as tradições messiânicas $(1,41)$, e a concepção do Filho de Deus (Jo 1,34) com a ideia acerca do Filho do Homem $(1,51)^{412}$. O título ui ò toul qeod não tem, nos primeiros estratos cristológicos, nenhuma significação ontológica, à maneira da dogmática posterior (Cf. Rm 1,4 denota um ofício ou função). Pode-se, pois, afirmar que nesta etapa primitiva da cristologia, o título de Filho de Deus é outra maneira de falar do Senhor ressuscitado como Messias (Mc 14,61; Mt 16,16) ${ }^{413}$.

\footnotetext{
${ }^{408}$ No Evangelho, a expressão Filho do Homem aparece em 1,51; 3,13; 3,14-15; 3,16-21. 31-36; 6,27. 53. 62;8,28; 9,35;12,23. 34c. 34d; 13,31; 19,37. João não traz, como os Sinóticos, a segunda vinda; ele não se apresenta em dependência direta da tradição sinótica (cf. a aproximação da hora escatológica 12,23; Mt 24,30). É interessante notar que se trata de uma tradição ulteriormente modificada e desenvolvida, que se aproxima, em algumas sentenças, dos enunciados apocalípticos (cf. 1,$51 ; 12,23)$ e da tradição sapiencial $(3,13 ; 6,62)$. Cf. HAHN, F., verbete ui ò anqrupou In BALZ, H. ; SCHNEIDER, G., op. cit., p. 1842 et seq.

${ }^{409} \mathrm{Na}$ tradição siríaca se mantém o modo original de referir-se a "o Filho do homem" com o artigo, à diferença, no grego do NT, onde de modo único, nenhum dos dois termos levam o artigo. Cf. LUZARRACA, J., El Evangelio de Juan en las versiones siríacas, Subsidia Biblica n. 33, 2008, p. 94.

${ }^{410}$ Cf. ASHTON, J., Comprendere il Quarto Vangelo, Città del Vaticano: Ed. Vaticana, 2000, p. 337 , nota 62.

${ }^{411}$ Em Dn 7,13 foi explicitamente dado ao Filho do Homem pelo Ancião o poder (o domínio) e a honra; mas o poder de julgar não está explícito, como nesse texto (vv. 22b e 27a). Cf. HAHN, F., verbete ui òj amqr wpou In BALZ, H.; SCHNEIDER, G., DENT, p. 1842 et seq.

${ }^{412}$ Cf. LÉON-DUFOUR, X., Leitura do Evangelho segundo João, p. 46 et seq.

${ }^{413}$ Para expressar essa profunda intimidade entre o Pai e Jesus, João se encontra ante uma dificuldade linguística. A expressão que podia parecer mais adequada para expressá-la, "Filho de
} 
Na teologia da filiação divina do Evangelho de João Jesus fala em termos claros das relações entre o Filho e o Pai, portanto, a expressão ui òj tou/ qeoł (v. 25d) tem o sentido da doutrina da Encarnação: Deus enviou seu Filho que fala suas palavras, quem o ouve escuta a voz do Filho único de Deus, que é o revelador de Deus $(1,18)$, comunicando aos homens, inclusive aos nekroj (mortos), a vida eterna que vem de Deus.

No v. 26 o termo nekroj não se usa somente em sentido próprio, mas também em sentido figurado. No NT se emprega quase sempre no plural quando se relaciona com a ressurreição (86 vezes). Aqui a linguagem é metafórica, pois se refere a ação de Deus de vivificar os mortos conferida ao Filho pela exousia de poder fazer julgamento (cf. também v. 21a) ${ }^{414}$. Acentua a prioridade temporal de Jesus porque corresponde a esta posição de poder dar vida a todos os seres humanos (v. 27) ${ }^{415}$.

O dom da ressurreição aos mortos já sepultados (vv. 28-29) se identifica com aquilo que na linguagem apocalíptica é representado pelo "dia do juízo". A alusão a Daniel 12,1-3s num contexto escatológico de julgamento é clara, e esses versículos introduzem um anúncio que, superando o tempo, atinge o último dia. O papel do Filho é apresentado não somente no decurso do devir do mundo, mas também por ocasião do seu fim (cf. 6,34). Porém, não se diz em Daniel que ao ouvir a voz do Filho os sepultados sairão.

\subsection{4.}

\section{A semântica do quarto motivo (v. 30)}

O Filho, cuja vinculação com o Pai, a partir da mesma obra, é afirmada desde os versículos $19 \mathrm{f}$ e 19g, agora se automanifesta com um egw,absoluto no v. 30a, retomando a mesma ideia de unidade com o Pai: Oudunanai egw. poi ėh apV

Deus", não se adaptava a seu propósito. No AT conforme Dt 32,8; Sl 29,1; 89,7 Jó 1,6; 2 Sm 7,14, havia servido para designar anjos, membros da corte celeste, criaturas de Deus superiores aos homens. Para solucionar esse problema, João vai de maneira paradoxal suprimir o determinativo "de Deus", para poder assim destacar o título de Filho que justapõe ao de Pai. A tradição sinótica não ignorava a expressão o 'u òj porém João a sistematiza (Mt 11,27 || Lc 10,22). Cf. HAHN, F., verbete ui òj In BALZ, H.; SCHNEIDER, G., op. cit., p. 1850 et seq.

${ }^{414}$ Pelo ângulo cristológico o envio do Filho de Deus se explica por suas relações com o Pai. A cristologia das relações Pai - Filho se emprega de modo analógico, e de cara, a vivificação e o juízo ocultam no fundo as concepções apocalípticas do judaísmo de então, concepções que aqui passam propriamente do futuro escatológico ao presente do Filho. Cf. SCHNACKENBURG, R., El Evangelio según San Juan, pp. 136-137.

${ }^{415}$ Cf. DABELSTEIN, R., verbete nekroj In BALZ, H.; SCHNEIDER, G., DENT, p. 384. 


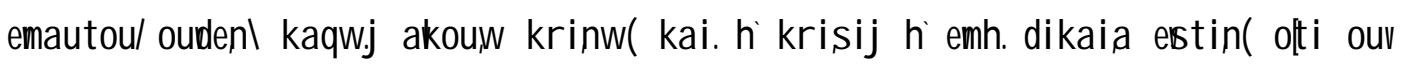
zhtw/ to. qel hma to. exon all a. to. qel hna toul penyantog n®ÅNesta passagem o egw, absoluto vem acompanhado por termos que indicam sua característica reveladora: krinw, akoun, qel hna, penpw ${ }^{416}$. O “egw. krinw' expressa o agir divino. O mistério da identidade de Jesus é o de sua origem, está em ser Filho, isto é, em proceder do Pai: "nonogenhj geoj o`wh ejj ton kol pon tou/ patroj eké hoj enghsato", coisa que os homens desconhecem (cf. 6,42) ${ }^{417}$. A teologia do envio (v. 30), da Palavra reveladora que se fez carne $(1,14)$, que estava voltada para Deus e era Deus $(1,1)$ está sujacente a esse egw, que assume sua existência histórica.

O pronome pessoal de primeira pessoa egw, substitui o "o ui òj” do v. 19d: "ouvdunatai o' uiòj poièn aff eàutoul ouden @n nh, ti bl ephl ton patera poi ounta”. Como declaração da identidade de Jesus é próprio do Evangelho de João ${ }^{418}$. Por conseguinte, o autor ao solicitar a fé "Naquele" que o enviou "tw"| penyanti, ne ecè", está solicitando a fé na encarnação do Filho de Deus (cf. 16,28: "sair do Pai").

\footnotetext{
${ }^{416} \mathrm{O}$ Cristo Joanino desceu do céu para fazer a vontade do Pai que o enviou $(6,38)$. As fórmulas de envio se transformam, assim, em fórmulas que expressam uma "cristologia da Encarnação". A chave de interpretação desse tema é o Prólogo. A Palavra se faz carne, assumindo a identidade de Jesus. Revelação pela Palavra, revelação por uma pessoa: Jesus. O Cristo joanino possui duas dimensões: Divina e eterna - humana e terrena. O evangelho tem cuidado para não deixar aflorar nenhuma separação ou ruptura, que divida Jesus Cristo (Jo 1,14: carne e glória). Cf. MANNS, F., L'Évangile de Jean et la Sagesse, p. 75.

${ }^{417}$ Cf. TUÑI VANCELS, O. J., O testemunho do Evangelho de João, p. 47.

${ }^{418}$ O pronome egw, seguido pelo verbo è wn formando a expressão - egw, è das expressões chave da cristologia joanina. O uso frequente dessa expressão por Jesus evidencia sua importância teológica para o Evangelho de João. O egw, è xñ não é simples declaração de identidade. Assume valor epifânico - Onde eu estou, ali está Deus (A mais ousada afirmação de Jesus sobre si mesmo). Jesus reivindica a participação na própria eternidade de Deus $(8,58)$. Participação no ser divino - Cristo se apresenta como porta voz de quem o enviou: 8,26. 29. O egw, e exin expressa a transcendência salvífica do Revelador para os que escutam sua voz. Eu Sou autoproclamação de Jesus em linguagem simbólica, como a realização daquilo que os grandes símbolos do povo bíblico e mesmo da humanidade apontam. Em quatro textos nos quais o uso do EU SOU é absoluto, sem predicado, a expressão assume a fórmula de um título $(8,24$. 28. 58; 13,19). No Antigo Testamento a revelação do nome de Deus se encontra em Ex 3,13-14. Semelhante revelação leva a pensar na sarça ardente (3,14; Is 41,4; 43,11. 15. 25; 45,18-22). Porém é, sobretudo, no Dêutero-Isaías (44-55) que se transforma em um nome divino (Is 43,25; $51,12 ; 52,6)$. Jesus fala da mesma forma que fala Javé no Deutero-Isaías (cf. 8,28). João chama a atenção para as implicações de divindade que levam consigo o uso do egw, e min por parte de Jesus: 8,24. 28. 58; 18,5. O mesmo é a revelação de Deus. O egw, ė mn, acompanhado de um predicado explícito onde se descreve a Jesus mediante uma metáfora, aparece sete vezes: Eu Sou o pão da vida; Eu Sou a luz do mundo; Eu Sou a porta das ovelhas; Eu Sou o bom pastor; Eu Sou a ressurreição e a vida; Eu Sou o caminho, a verdade e a vida; Eu Sou a verdadeira vide. Cf. SCHNACKENBURG, R., op. cit., pp. 73-84.
} 
O termo qel hna também é carregado do sentido revelador do agir de Deus $^{419}$. Pode significar o que se quer objetivamente e a ação de querer. $\mathrm{Na}$ grande maioria dos casos se refere à vontade de Deus. Na oração do Pai-Nosso, no Evangelho de Mateus, se pede que seja feita a "vontade do Pai" (Mt 6,10). O sentido da vontade de Deus sem dúvida é que a verdadeira vida do homem se alimenta da obediência aos mandamentos de Deus (Dt 8,3). A vontade de Deus se identifica com a Torá (Mt 7,21-23). Nos Sinóticos significa a submissão de Jesus à vontade de Deus (Mt 26,42; Lc 22,42) ${ }^{420}$. No Evangelho de João, Jesus designa, precisamente, "a vontade Daquele que me enviou" como a razão e o conteúdo de toda sua vida (v. 30e; 4,34; 6,38). Essa vontade se cumpre no Filho, posto que a vontade do Pai constitui o eixo de tudo o que o Filho diz e faz, é completamente dependente da palavra e da vontade de seu Pai. Jesus não só revela, mas também realiza a vontade de quem o enviou ao julgar segundo o que ele ouve (v. 30b; cf. 6,39-40; 12,24). É seu firme compromisso de não agradar a si mesmo, mas àquele que o enviou, que garante que ele está completamente de acordo com seu Pai. Por conseguinte os leitores do Evangelho podem estar certos de que o julgamento que Jesus exercerá é perfeitamente justo $(\mathrm{v} .30 \mathrm{~b})^{421}$. Portanto, ao realizar um “julgamento justo" Jesus se alimenta da prática da vontade de Deus (v. 30c).

\subsection{5.}

\section{A semântica do quinto motivo (vv. 31-39)}

O substantivo marturia (testemunho) pode ser considerado um termo joanino, pela frequência com que aparece no Evangelho e nos escritos do mesmo grupo (Cartas e Apocalipse) ${ }^{422}$ e sempre no singular. No texto do discurso (vv. 19-47) o termo narturia aparece nos versículos: 31b, 32c, 34a, 36a. Por ser

\footnotetext{
${ }^{419}$ Cf. LIMBECK, M., verbete qel hna In BALZ, H.; SCHNEIDER, G., DENT, p. 1842.

${ }^{420}$ DODD, C. H., La Tradición Histórica en el Cuarto Evangelio, Madrid: Cristiandad, 1978, p. 326.

${ }^{421}$ CARSON, D., O comentário de João, p. 260.

${ }^{422} \mathrm{O}$ termo marturia no sentido de declaração de um testemunho, no NT aparece 37 vezes: Em Mc três (14, 55. 56. 59 e no v. 63 marturwh testemunhas no plural.); em Lc (22,71 marturiaj) e At $(22,18)$ uma vez cada um e nas pastorais duas vezes $(1 \mathrm{Tt} 1,13 ; 1 \mathrm{Tm} 3,7)$. As outras ocorrências se encontram nos escritos joaninos: No Evangelho 14 vezes, em 1 Jo 6, na 3 Jo uma vez e no Ap 9 vezes. Cf. BEUTLER, J., verbete marturia In BALZ, H.; SCHNEIDER, G., DENT, p. 175 .
} 
derivado $^{423}$ do verbo narturen (testemunhar) ${ }^{424}$, a ideia que ele porta tem uma forte presença no texto (vv. 31a, 32a, 33b, 36e, 37b, 39d). Pode-se distinguir entre um uso ativo do termo (a ação de dar testemunho, cf. 1,7) e um uso passivo: a deposição de um testemunho; isto é, um testemunho dado ou em sentido figurado (cf. Mc 14, 55. 56. 59; Lc 22,71). No NT é a atestação de um fato por parte do homem. Indica antes de tudo declarar ou confirmar um fato na base de um conhecimento direto. Tem o sentido de atestar uma boa reputação. O testemunho tem por objeto uma verdade revelada e crida. Porém nos escritos Joaninos tem um uso particular ${ }^{425}$.

O evangelista conhece um duplo uso característico da ideia do testemunho: segundo João, Jesus é testemunha de coisas celestiais (cf. 3,11. 32). Esse modo de falar pode ter como pano de fundo as ideias apocalípticas do judaísmo. Porém em João 5,31-40 e 8,12-20 trata-se da ação de testemunhar que, à maneira de uma confrontação judicial com “os judeus", deve legitimar a pretensão de Jesus de ser o revelador divino ${ }^{426}$.

O objeto do testemunho é a relação indissolúvel entre Jesus e o Pai. Ora, esta realidade não foi compreendida à margem de Jesus, à margem de sua realidade histórica, de sua sarx A grande questão é que não se pode dar testemunho da glória, da verdade, da luz, sem falar do homem Jesus. A figura histórica de Jesus é o ponto de referência essencial. O objeto do testemunho é, portanto, a glória percebida em Jesus. Nem a mera história de Jesus sem sua glória, nem a glória à margem de Jesus. Os verbos de experiência que marcam o objeto do testemunho evangélico da obra joanina: bl epw (ver), akaum (escutar),

\footnotetext{
${ }^{423}$ Cegalla afirma que um substantivo deverbal está na dependência do verbo. Assim o termo marturia está na dependência do verbo nartureN por ser um deverbal. Cf. CEGALLA, D. P., Novíssima Gramática da Língua Portuguesa, São Paulo: Editora Nacional, 1989, p. 82.

${ }^{424} \mathrm{O}$ verbo martur $\Theta \mathrm{N}$ aparece com maior frequência no Ev. de João (33 vezes das 76 no NT afora 10 vezes nas cartas dele). Usado em sentido absoluto martureN significa dar testemunho (1 Jo $5,6 \mathrm{~s}$ ) ou também afirmar solenemente (Jo 12,17; 13,21). Com acusativo de coisa significa atestar, e o mesmo sentido tem com ofi $(4,44)$. Com dativo de pessoa e ofi, o verbo narturen significa confirmar/ testificar alguma coisa a alguém (Jo 3,28s). Se se fala de dativo de coisa, então significa "dar testemunho em favor de algo" (unicamente no Evangelho de João, 3 Jo, At 14,3). A construção marturen peri.ting que aparece 19 vezes em João e que fora deste evangelho não se encontra no NT, a não ser na 1 Jo por certo refere-se sempre a Jesus. Em todo o Evangelho a "Fé" joanina está sempre referida a testemunhos. Cf. BEUTLER, J., verbete narture In BALZ, H.; SCHNEIDER, G., DENT, p. 168 et seq..

${ }^{425}$ Cf. STRATHMANN, H., verbete marturia In KITTEL, G.; FRIEDRICH, G., GLNT, p. 1334, et seq.

${ }^{426}$ Sobre o testemunho a favor de si mesmo: no tratado judaico mishnaico Kethuboth, 2,9 se estabelece também o princípio de que ninguém pode testemunhar a favor de si mesmo. Cf. BROWN, R., El Evangelio según Juan, p. 434.
} 
f il eN (amar) qd w(querer), acentuam indiretamente essa experiência sensível que está na base da fé e do seguimento ${ }^{427}$.

No v. 31 se reconhece o princípio jurídico de que o testemunho do interessado não tem valor num processo e Jo 8,17 admite o princípio que é preciso dois ou três testemunhos. Nos versículos 35-39 Jesus apela para alguns testemunhos. Jesus reconhece que João Batista lhe deu testemunho, mas o testemunho deste era insuficiente para justificar sua filiação divina ${ }^{428}$. Ele reconhece a João Batista o título de profeta, mas para justificar sua filiação divina ele apela aos testemunhos mais autorizados. O testemunho de João Batista se situa no contexto da polêmica na qual os judeus acusam Jesus de pretender ser Filho de Deus $^{429}$. No processo que lhe movem, Jesus tem necessidade de testemunhos. Apesar disso, Jesus insiste em que seu testemunho é verdadeiro ${ }^{430}$ porque ele não está só.

O uso do adjetivo akhqhi no Evangelho de João reúne todos os matizes do espectro de significados de alhqeia: verdadeiro, fiável, veraz, crível, fiel. Deus é verdadeiro porque Deus, no Filho, se revela como a Verdade (cf. 3,33; 7,28; 8,26; 17,3). Especialmente aqui alhohi (v. 31) aparece junto a testemunho, no sentido de que tudo quanto o Filho diz e faz é verdadeiro ${ }^{431}$. Jesus afirma que sua missão se completou, porque ele levou a termo suas obras (v. 36b-c) ${ }^{432}$. O que lhe enviou está com ele (v. 36f; 37a-b) ${ }^{433}$.

\footnotetext{
${ }^{427}$ TUÑI VANCELS, O. J., O testemunho do Evangelho de João, p. 168.

${ }^{428}$ Cf. MANNS, F., L'Évangile de Jean et la Sagesse, p. 315.

${ }^{429}$ Não há dúvida de que o texto reflita uma situação missionária na qual havia de se justificar todas as pretensões atribuídas a Jesus, como as que estão nas seções precedentes. Porém, é claro o interesse do autor de aquilatar os diversos testemunhos (João Batista, AT, as Obras) que qualquer missionário cristão não estaria em condições de colocar. O tema do testemunho é central no Evangelho, sublinhando a oposição e o clima judicial em que se dá o testemunho a favor de Jesus (cf. v. 31b; 8,14). Cf. TUÑI VANCELS, O. J., op. cit., pp. 161-164.

${ }^{430}$ Cf. HÜBNER, H., verbete alhahi In BALZ, H.; SCHNEIDER, G., DENT, p. 171 et seq.

${ }^{431}$ O termo "obra" como objeto do verbo designa, sobretudo, a obra de Deus, realizada pelo Pai em Jesus. Cf. FERRARO, G., Il Paraclito, Cristo, Il Padre nel Quarto Vangelo, p. 30.

${ }^{432}$ Cf. TUÑI VANCELS, O. J., op. cit., 1989, p. 59.

${ }^{433}$ No contexto da grecidade clássica a-létheia - com a letra a- privativa e a raiz lanthanō (esconder) - tem o sentido de desvelar, abrir, sublinhando o revelar-se da realidade na sua essência, e, portanto, o aspecto ontológico do ente. O termo hebraico 'emet, ao contrário, está em relação com a raiz 'aman e põe em evidência a estabilidade, a credibilidade. No seu significado é muito próximo a justiça, entendida como «retidão». Na LXX, de fato, 'emet vem traduzido também com pistis dikaiōsynē. No binômio hesed we'emet (fidelidade e veracidade) (cf. Ex 34,6), os dois termos se iluminam reciprocamente, deixando entender que o termo «verdade», na linguagem religiosa hebraica, não se tem o que fazer simplesmente com o aspecto lógico. A verdade vem compreendida melhor como expressão do agir, tanto é verdade que - na Bíblia hebraica - a verdade de Deus se identifica com a sua fidelidade às promessas (S1 31,6; Is 38,18-19). Cf. GRILLI, M.,
} 
O termo "€rgon" (obra) como objeto do verbo designa, sobretudo, a obra de Deus, realizada pelo Pai em Jesus. O objeto do dom divino são as obras de Jesus: v. 36. A estrutura das obras ( $₫$ ga) é exatamente a mesma das palavras. Jesus fala, e as palavras que diz não são propriamente suas, mas daquele que o enviou ao mundo (cf. 7,16; 14,24). Jesus diz apenas o que ouviu junto do Pai (v. 30b; 8,26; cf. 8,$40 ; 12,49)$. Jesus recebeu do Pai as palavras que deve pronunciar $(17,8)$. Por isso Jesus guarda a palavra que recebeu $(8,55)$, e a dá aos homens $(17,14)$. E os homens devem escutá-la (v. 24b; 7,40; 14, 24), devem guardá-la $(8,31 ; 15,7$; 17,6), devem recebê-la (12,48). Esta palavra os leva à fé (v. 38a-b-c; cf. 8,37), creem mediante a palavra (v. 24c; cf. 4,41).

No v. $34 \mathrm{c}$ o que Jesus fala tem por objeto a salvação ${ }^{434}$. O termo swłw quer indicar a ação salvadora de Deus no mundo por meio de sua Palavra que se fez carne, Jesus, seu Filho. Esta ação que Jesus realiza não tem como consequência só a saúde do corpo, mas também a salvação no sentido mais amplo da palavra. $\mathrm{O}$ enviado ao mundo veio para reverter a condição da criatura diante do Criador $(3,16)$. A salvação no sentido de acolhimento ao dom de Deus. Tal é a meta que Jesus propõe aos seus ouvintes no v. 34c. A verdade dos ensinamentos do Filho se revela naquele que se entrega igualmente ao cumprimento da vontade de Deus (v. $30 b ;$ cf. 7,17. 28).

Os versículos 37c-37d, fazem clara referência à idéia da intimidade de Moisés com Deus que é um dos temas centrais que percorre todo o capítulo 33 do Livro do Êxodo: "YHWH falava face a face com Moisés, como um homem fala com seu amigo" (Ex 33,11). O mais profundo desejo do homem é ver a Deus "face a face". No AT a visão de Deus está relacionada a uma experiência privilegiada $^{435}$. O desejo de ver a Deus só rara e parcialmente é satisfeito, pois Deus é um Deus escondido (cf. Is 45,15 ) que se revela à fé ${ }^{436}$. Os ouvintes conheciam perfeitamente a súplica pessoal de Moisés: "Mostra-me, por favor, tua glória" sem similar no AT (Ex 33,18ss). A afirmação joanina retoma a temática na intenção de apropriar-se de seu significado, conforme já declarado no Prólogo (Jo 1,18). Indicando que somente o Filho viu a Deus exclui que alguém o tenha visto

Pragmatica e analisi del texto. Disponível em: http://www.evangeliumetcultura.org/ IT/Pragmatica\%20e\%20analisi\%20del\%2Otesto.php Acessado em 14 de maio de 2012.

${ }^{434}$ Cf. RADL, W. A., verbete SUkw In BALZ, H.; SCHNEIDER, G., DENT, p. 1635 et seq.

${ }^{435}$ Cf. Moisés (Ex 33), Elias (1 Rs 19,13) Isaías (6,1ss).

${ }^{436}$ Cf. LÉON-DUFOUR, X., Verbete ver In LÉON-DUFOUR, X,. Vocabulário de Teologia Bíblica, p. 1054. 
antes (vv. 37c). Portanto, o que a voz do Filho de Deus revela é superior a qualquer outra revelação, embora não negue os meios de revelação na história do povo de Israel e na criação (v. 39a). O texto de João destaca que a filiação de Jesus é superior a qualquer outro relacionamento com Deus. Isto traz uma mudança notável na mediação: a mediação de Moisés (cf. Ex 33,11) que como amigo íntimo intercedeu para que YHWH não abandonasse o seu povo (Ex 31,18; cf. 34,27-28) garantiu sua presença (Ex 33,14ss), mas não um justo julgamento: a reconciliação do povo com seu Deus e a ressurreição de vida (v. 29. 30b).

A única voz que faz ecoar a Palavra de Deus de modo que ela permaneça é a do Filho de Deus (v. 38a). Portanto, permancer (nenw) ${ }^{437}$ aqui tem o sentido de manter-se firme na fé no acontecimento salvífico da presença de Deus em Jesus. Esta forma verbal nenw tem especial relevância teológica nos escritos joaninos na citações sobre a imanência: Jesus exige dos seus ouvintes que pemaneçam nele; isto é, que o aceitem como a Palavra de Deus que se fez carne (v. 38a).

Essa Palavra realiza e plenifica as das Escrituras (graf ai) porque é portadora de vida Eterna (v. 39b). Portanto, somente as Escrituras (graf ai ) não são suficientes para dar à condição humana a vida da eternidade (v. 45a-b-c). graf $h,{ }^{438}$ é o substantivo deverbal de graf $\mathrm{w}$ no sentido de expressar o conteúdo das Sagradas Escrituras em geral (v. 47a).

\subsection{6.}

\section{A semântica do sexto motivo (vv. 40-47)}

No ambiente semântico da revelação e interpretação das Escrituras o verbo I anbannw é um termo para expressar a recepção da revelação pela Palavra de Deus. Ele comparece neste texto nos vv. 41, 43b, 43d, 44b e pertence ao campo léxico de receber, aceitar, acolher, tomar, pegar com a mão ${ }^{439}$. O significado receptivo é o mais realçado no Evangelho de João, e se amplia por meio de expressões fixas: "quem recebe aquele que eu enviar recebe a mim e quem me recebe, recebe aquele que me enviou" $(13,20)$, "receber glória" (v. 41), "receber o testemunho" (v. 34a) "receber graças" $(1,16)$, "poder receber" $(14,17)$. A expressão aceitar um

\footnotetext{
${ }^{437}$ Esta forma verbal é predominantemente joanina. Em seus escritos aparece 67 vezes, sendo que 40 vezes no Evangelho, 24 na 1 Jo e 3 na 3 Jo.

${ }^{438}$ Cf. HÜBNER, H., verbete graf h,In BALZ, H.; SCHNEIDER, G., DENT, p. 786 et seq.

${ }^{439}$ Cf. KRETZER, A., verbete I anbanw In BALZ, H.; SCHNEIDER, G., DENT, p. 5.
} 
testemunho - ou não aceitá-lo - é um elemento importante na teologia joanina, tanto com respeito à soberania de Cristo (v. 34) quanto à decisão que o homem deve adotar: aceitar ou rechaçar (v. 43). I anbanw ${ }^{40} \mathrm{O}$ sentido etmológico originário do vocábulo é tomar, aceitar mas pode ser usado no sentido ativo e no passivo. No sentido ativo tem o sentido de receber uma sentença, tomar uma iniciativa pessoal na própria esfera da ação: tomar consigo, tomar uma esposa; apanhar, no sentido passivo, receber, obter e no tempo médio o uso tem valor ativo: aderir a alguém ou alguma coisa. No NT em João tem o sentido de acolher na fé o testemunho de Jesus (Jo 3,11. 32s; 12,48; 17,8 e de seus enviados 13,20. Em 5,43, acolher o próprio Jesus como o $\operatorname{Logos}(1,12)$.

Em correspondência com a aceitação está o termo doxa (glória) ${ }^{441}$ que é, também, uma expressão chave no Evangelho de João e se refere à manifestação do poder de Deus em Jesus ${ }^{442}$, isto é, ao reconhecimento da presença divina nele. No texto de Jo 5,19-47 o termo "Glória" (doxa) aparece no contexto em que Jesus fala do testemunho das Escrituras (vv. 41. 44b. 44c), estando seu sentido carregado da ambiguidade da linguagem joanina (cf. v. 44b). Nos vv. 41 e 44b porta o sentido do termo grego doxa, que no grego clássico e no helenista significa normalmente "opinião", "reputação", valor, honra ${ }^{443}$; e no v. 44c no sentido bíblico judaico de "Glória de Deus", esplendor do poder divino, e se entende como sendo a revelação do poder de Deus, ou como sendo uma intervenção na história, feita pelo poder de Deus e por iniciativa dele ${ }^{444}$. O tema da glória ${ }^{445}$ não

\footnotetext{
${ }^{440}$ Cf. DELLING, G., verbete I anbanwIn KITTEL, G., GLNT, p. 22 et seq.

${ }^{441}$ É um termo muito importante para o evangelista. A glória é uma associação teológica que está na dependência do sentido Bíblico-judaico e pertence ao campo semântico teofânico. Na LXX, doxa traduz, em geral, o termo hebraico dok"e denota, especialmente, a manifestação visível (com frequiência, da luz) que acompanha a uma teofania. BARRET, C. K., El Evangelio según San Juan, p. 249.

${ }^{442}$ A "Glória de Deus" é um conceito teológico complexo. Cf. SCHNACKENBURG. R., $E l$ Evangelio según San Juan, p. 285.

${ }^{443}$ No v. 23 o termo para honra é ti nowsi, ti nh,no sentido de prestígio.

${ }^{444}$ AALEN, S., Verbete doxa In COENEN, L.; BROWN, C., DITNT, v. 2, São Paulo: Vida Nova, 2000, pp. 900-902.

${ }^{445}$ Nas tradições do Êxodo a glória de YHWH é descrita em termos que sugerem a coluna de nuvem e a coluna de fogo. Essas eram manifestações visíveis da presença e proteção de YHWH (cf. Ex 16,7. 10; Lv 9,6. 23; Nm 14,22; 16,19; 17,7; 20,6). O Antigo Testamento fala com frequêencia da dok Glória ou da Honra de Deus. O termo hebraico dok empregado em tal sentido, significa originalmente "pesadume, peso" e, conseqüentemente, a consistência, a importância de alguém, o que significa respeito, riqueza, poder ou êxito, o valor real do que existe: das coisas e das pessoas. Mas a mentalidade semítica não concebe uma realidade consistente, importante, "que pesa", que não seja ao mesmo tempo "radiante". Não consegue admitir que o que "pesa" não faça sentir seu peso, seu poder. A glória simboliza a riqueza essencial que se reflete nas coisas. É o brilho da magnificência e do poder divinos, cintilando sobre alguma realidade criada, ou sobre
} 
mostra apenas o reflexo da presença eficaz de Deus sobre alguma realidade da criação ou da história, mas expressa também esta presença. A glória de Deus se manifesta em sua ação, fiel a seu próprio caráter, e este caráter se manifesta como "graça", portando, também, o sentido de "salvação" (cf. Jo 1,14) ${ }^{446}$.

No Evangelho a "glória" se manifesta nas ações e palavras de Jesus, portanto, em sua carne, e aí pode ser contemplada: "nós vimos sua glória" $(1,14)$ e "manifestou sua glória" $(2,11)$. Nesse sentido, a expressão "ver a glória"447 é usada no caso da revelação de Deus, sendo considerada uma forma autônoma de manifestação de Deus em função de sua revelação e podendo apresentar-se quase independente dele.

A aceitação da manifestação da presença de Deus em Jesus, portanto, de sua glória, acarreta inúmeras dificuldades para os ouvintes. Por isso o texto remete a Moisés. Também o contexto no qual Moisés suplica para ver a glória de Deus é da incerteza de sua presença no meio do povo de Israel $^{448}$. O contexto do Evangelho de João também era de insegurança para a nova comunidade de fé que buscava consolidar sua identidade cristã exigida pelas circunstâncias ${ }^{449}$. A proclamação do I ogo encarnado em Jesus Cristo exigiu a necessidade de testemunhos (v. 39d) e provas das Escrituras (vv. 39. 47), pois se recusavam a aceitar Jesus como Filho de Deus. Portanto, o tema da natureza da presença de Deus é retomado por João para apresentar Jesus como o Filho único, aquele que faz Deus presente no meio dos homens.

algum evento da história (cf. Ex 14,18; 16,7; 24,17). Cf. Verbete ddk JENNI, E.; WESTERMANN, C., DTMAT, v. 2, Madrid: Cristiandad, 1985, pp. 1090-1113.

${ }^{446}$ Cf. GARCIA-MORENO, A., Temas Teológicos del Evangelio de San Juan, v. 1, Madrid: Ediciones Rialp, 2007, p. 35.

${ }^{447}$ A expressão "ver a glória" no AT é usada como termo técnico para a aparição de Deus em um lugar que foi por ele santificado. A glória de Deus reside no Templo (cf. Ex 29,43) e significa a presença de Deus ali (cf. Ex 29,42-46; 40,34-35). Cf. Verbete har JENNI, E.; WESTERMANN, C., op. cit., p. 881.

${ }_{448}$ A consciência de haver perdido o contato imediato e familiar com Deus provocou no povo o temor permanente de que em sua ira poderia abandoná-los (Ex 32,30-35). Daí, a esperança infatigável de buscar a reconciliação por meio da mediação de Moisés. A intercessão de Moisés (Ex 33,12-23) garantiu a presença de Deus e a renovação da Aliança com novas "Tábuas da Lei" (Ex 34,1-9), mas não ficou claro de que modo ele se faria presente $(33,12-17)^{448}$. Cf. Ex 32-33 e também os textos e salmos ligados ao período do pós-exílio: Is 41,14; 60,1-22; 62,4-5; 66,5; Sls $42 ; 63 ; 67 ; 77$; etc.

${ }^{449}$ A guerra romana que destruiu o Templo e Jerusalém (68-70 d.C.), a reorganização do judaísmo farisaico (+ ou -90 d.C.), as inúmeras filosofias com substrato religioso (gnose, mandeísmo, hermetismo), que pululavam na região da bacia do Mediterrâneo, além da perseguição de Domiciano (81-96 d.C.). Porém, a separação do judaísmo foi a circunstância que mais exigiu uma nova reflexão do dado da fé. Os judeus depois da guerra dos anos 70 se fecharam em sua própria ortodoxia. Cf. FABRIS, R.; MAGGIONI, B., Os Evangelhos, 2 v, São Paulo: Loyola, 2006, p. 265. 
Assim, uma profunda mudança ocorre no modo da revelação do AT: agora, no NT, ela acontece na carne de Jesus Cristo, a Palavra eterna do Pai, e não mais escrita nas tábuas de pedra (cf. Ex 34,1-9). João afirma que a Glória de Deus se manifestou em Jesus $(1,14)$ e especialmente em suas obras, pela percepção dos "sinais" mediante a fé (cf. 2,$11 ; 11,40)$. Para o evangelista esta manifestação corporal da glória em Jesus atinge o mais alto grau através de sua exaltação e morte na cruz, "sua glorificação" (glorificação/exaltação: Jo 12,23. 28; 13,31; $17,1 \mathrm{ss})$.

Essa realidade é considerada. Jesus a conhece (gi nw\$kw). Para ele a questão é de fé, de aceitação no novo modo de presença de Deus entre os homens. O verbo gi nuskw ${ }^{450}$ é usado em João no sentido de chegar à fé no revelador, e significa também, principalmente, a certeza da fé, o fato de perseverar na fé. É paralelo ao de crer ou de amar a Deus ou de ver a Deus.

A locução prepositiva en tw/ ononati ("em nome de" v. 43a), "em seu próprio nome" (eq tw/ anonati $t w / i d w / v .43 c$ ) tem especial destaque na teologia joanina do "envio" (vv. 23e, 24d, 30e, 36f, 37a, 38b). A pessoa do enviado age conforme quem o enviou. "Em seu nome" equivale "em sua pessoa", por meio dela. Se a pessoa é enviada por Deus o nome vem a ser o próprio Deus. Agir em seu nome significa ter o poder de quem o enviou. Na tradição judaica, Deus de tal modo se identifica com o seu nome, que, dele falando, ele se designa a si próprio $^{451}$. No Novo Testamento “o nome do Pai”, a revelação pela qual Jesus deu a conhecer a seus discípulos o nome de seu "Pai" (v. 43; cf. 17,6. 26; Mt 11,25ss), corresponde à revelação que Deus fez de seu nome no Antigo Testamento. Jesus pede ao Pai que glorifique seu nome (Jo 12,28). Deus fará isso manifestando sua "glória e seu poder" e glorificando seu Filho (Jo 17,1. 5. 23ss). O objetivo próprio da fé cristã joanina é crer no "nome" do Filho único de Deus $(3,18 \mathrm{~s}$; cf. 1,12; $2,23 ; 20,30)$ isto é, aderir à pessoa de Jesus, reconhecendo que ele é o Filho de Deus, que "Filho de Deus" é o nome que exprime seu verdadeiro ser (cf. Jo 5,25d). Jesus, como o Filho de Deus, é seu mais qualificado intérprete, consequentemente, é o representante legítimo do novo Israel.

\footnotetext{
${ }^{450}$ Cf. SCHMITHALS, W., verbete gi nuskw In BALZ, H.; SCHNEIDER, G., DENT, p. 755.

${ }^{451}$ A fim de melhor marcar a transcendência do Deus inacessível e misterioso o "Nome" basta para designar a Deus em Israel. Em um texto do Levítico (Lv 24,11-16) o "Nome" designa Javé sem maior precisão, como fará mais tarde o linguajar rabínico. Cf. LÉON-DUFOUR, X., VTB, p. 649.
} 
A forma verbal kathgor $\mathrm{N}^{452}$ (acusar) aqui está usada no particípio presente na função de nome, isto é, de sujeito; sendo Moisés o predicativo do sujeito. Portanto, tem o sentido de "o ouvinte" ser acusado diante de Deus pela própria decisão de não acolher a revelação de Deus, no seu enviado, e não pelo que Moisés escreveu, pois o que ele escreveu já anunciava o "dom" que está sendo oferecido. A Palavra de Deus que se fez carne, habitando no meio de nós $(1,14)$, é a única forma de manter a esperança em Sua presença no meio dos homens.

\section{3.}

\section{A sequência estratégica dos motivos}

Compreender a estratégia sequencial dada aos motivos em um processo de comunicação é importante para avaliar a função hierárquica das ideias que compõem o tema.

\subsection{1. \\ 19 Momento (vv. 19-23)}

Se a intenção do autor é apresentar os fundamentos teológicos da relação filial de Jesus, o Filho, com Deus, o Pai, estrategicamente ele procura mostrar que Deus, o Pai, é e continua sendo a origem e a causa de todo o agir do Filho. O v. 19d que o inicia o discurso "ouvdunatai o uiò poi èh aff èutoul ouden é por demais revelador dessa intenção. Em primeiro lugar há o cuidado para situar os polos dessa relação: Quem é e o que faz o Pai, e quem é e o que faz o Filho.

A impossibilidade de "o Filho" agir independentemente do Pai, expressa logo no início em duas formas: negativa (o Filho nada pode fazer, exceto o que vê o Pai fazendo, vv. 19d-f) e positiva (o que o Pai faz o Filho o faz igualmente, v. 19g), domina o discurso. Assim como o Pai trabalha no sábado e em todos os dias, o Filho pode fazer o mesmo $(5,17)$. O v. 20 está em correspondência à afirmação do v. 19, segundo a qual o Filho vê o Pai trabalhar e lhe mostra tudo o que faz ${ }^{453}$. O trabalho do Pai aparecerá em seguida como o trabalho de dar vida aos

\footnotetext{
${ }^{452}$ Cf. ThWNT III, 368, verbete kathgoren In BALZ, H.; SCHNEIDER, G., DENT, p. 2263.

${ }^{453}$ Para Wengst esta passagem recorre ao modelo de santuário que Deus havia mostrado a Moisés (Ex 25,8-9) e que constitui o modelo do santuário celeste, base na qual a ação de Jesus se orienta. Cf. WENGST, K., Il Vangelo di Giovanni, p. 213.
} 
homens ${ }^{454}$ e de julgá-los (vv. 21a-22b) que é confiado ao Filho. Se o Filho vive na dependência total do Pai ele deve ser honrado igualmente como o Pai já que é seu enviado (v. 23e).

Essa reivindicação para o autor quer expressar a defesa do monoteísmo baseada sobre a fé de que nas obras de Jesus se revelam as obras de Deus de dar vida e fazer julgamento ${ }^{455}$. Ambos faziam parte constante da atividade de Deus. Em dia de sábado só Deus age ${ }^{456}$. De fato, a atuação de Jesus no sábado, era no pensamento do evangelista, uma forma de manifestar a divindade de Jesus (cf. 5,9. 16), e é isto que ele quer acentuar com a afirmação do versículo 5,17 ao fazer uso da forma verbal ergazhtai para falar do "fazer" do Pai e do "fazer" de Jesus. O sábado põe à luz a essência da ação de Jesus: sua obra é divina. Para o autor, Jesus se encontra diante de uma missão muito difícil: manter a verdade da afirmação da própria igualdade com o Pai e ao mesmo tempo fazer compreender que tal verdade não se contradiz com aquela da unicidade de Deus; nascendo, dessa maneira, o presente discurso, no qual o modo de trazer juntos os dois aspectos - a própria igualdade e o monoteísmo - consiste em alternar e entrelaçar enunciações de dependência do Filho em relação ao Pai. Essa sequência (vv. 19d23e) é a primeira, não só em ordem de colocação no texto, como também, em prioridade teológica da qual emana toda a substanciação argumentativa, sem a qual o discurso não se sustentaria.

\subsection{2. \\ 2o Momento (v. 24)}

A segunda seção continua a aprofundar a linguagem da filiação, enquadrada agora, em um marco de compreensão da pré-existência: o Filho está em função de um "envio" com a missão de expressar não só a relação íntima entre ele e Deus, o Pai, como também, e isto é muito importante para a teologia do texto, a verdade da revelação que Jesus faz de Deus (v. 24): É sua Palavra ${ }^{457}$.

Para o autor, pela categoria da "Palavra do enviado do Pai" pode-se superar a dificuldade para explicar a afirmação do Filho em 5,17: “Meu Pai trabalha até

\footnotetext{
${ }^{454} \mathrm{Em} 5,11$ e 5,15 as expressões o’ poi hsaj ne ug̀i $W$ e o’ poi hsaj auton ug̀i $W$ surpreendem porque são usadas em lugar de qer apeun de 5,10.

${ }^{455}$ Cf. MANNS, F., L'Évangile de Jean et la Sagesse, p. 143.

${ }^{456}$ Cf. BARRET, C. K., El Evangelio según San Juan, p. 386.

${ }^{457}$ Cf. MANNS, F., op. cit., pp. 148 e 141.
} 
agora, e eu também trabalho" ${ }^{\text {458 }}$. A ideia joanina de envio está marcada pelo direito judeu do enviado com seu axioma de que "o enviado de um homem é como este mesmo". Já na teologia do Êxodo firmou-se a fé na mediação de Moisés como porta voz do Deus libertador. A fé em YHWH se expressa como aceitação do enviado (cf. Ex 3,10; 4,12). Tema que toda a literatura profética torna a repisá-lo.

Os seguidores de Jesus leram a missão do Filho como "enviado" para realizar a obra de Deus, à luz desses textos, o que lhes permitiu dar continuidade à reflexão sapiencial com ênfase na preexistência e na mediação criadora do Filho ${ }^{459}$. O Evangelho, desde o início, proclama que "a Palavra estava em Deus e era Deus" $(1,1)$. A fé na "Palavra que se fez carne" é o meio pelo qual os homens poderão contemplar a "doxan wy nonogenai" para. patroj" ("glória do Unigêntio do Pai"; 1,14), isto é, a realidade da unicidade de Deus e da divindade de Jesus Cristo numa só presença.

A possibilidade de acesso do crente à vida de Deus depende, pois, da filiação de Jesus. A relação Pai - Filho abraça sempre de uma maneira implícita ou explícita aos homens. É, pois, uma relação produtiva para a humanidade, relação que faz os homens passarem da morte para a vida sem vir a julgamento (v. 24f). Esta relação é a que transmite a vida eterna (v. $24 \mathrm{e})^{460}$. Tudo o que recebe do Pai, o Filho dá aos que nele creem (v. 24). Portando a dimensão de apresentar o Filho, a Palavra reveladora do Pai, como o elo indissolúvel entre Deus-Pai e os homens, no qual "a Palavra dele" (v. 24b) convoca a todos para a vida, esta seção pode ser classificada como o segundo grande momento no desenvolvimento do discurso.

\subsection{3.}

3을 Momento (vv. 25-29)

A terceira seção demonstra como realmente o Filho pode dar vida e fazer julgamento. Os versículos 21a-b-c haviam declarado que como o Pai "levanta os

\footnotetext{
${ }^{458}$ Cf. MEEKS, W., Cristo é a questão, São Paulo: Paulus, 2007, p. 67.

${ }^{459}$ Cf. GILBERT, M.; ALETTI, J-N., A Sabedoria e Jesus Cristo, São Paulo: Paulinas, 1985, pp. 89-98.

${ }^{460}$ No Evangelho de João, em 17,3, o conceito de vida eterna está na dependência do conhecimento tanto de Deus quanto de Jesus Cristo. Esta citação está em estreita relação com o Prólogo, uma vez que somente aqui e em 1,17 o Filho enviado pelo Pai é chamado de "Jesus Cristo".
} 
mortos e os faz viver", assim também o Filho dá a vida a quem quer. E, a seguir, nos vv. 22a-b, a atividade de julgar do Pai foi confiada totalmente ao Filho. Por conseguinte, a retomada desse motivo, neste estágio do discurso é estratégica. Esta seção caracteriza-se por apresentar o "fazer" do Pai (vv. 21a-b-c) realizandose no "fazer" do Filho, que é o "Filho do Homem" (vv. 25-29), implicando, sobretudo, uma relação com os interlocutores. Nesses versículos percebe-se o eco de questionamentos sobre o alcance da atividade criadora e da atividade escatológica do Filho (vv. 26a-26b).

A resposta às perguntas pelo tempo e o momento do acontecimento salvífico, quem poderia ser por ele alcançado, como e por quem este se realizaria e suas consequências é o conteúdo desta terceira seção cujos aspectos escatológicos, novos e tradicionais, em novas configurações, criam espaço, por meio da inferência da expressão "ui òj anqor wpou' para salientar a pessoa histórica do "Filho" que será apresentada no seguimento do desenvolvimento do discurso.

\subsection{4. \\ 4을 Momento (v. 30)}

A manifestação pessoal (v. 30a) daquele que recebeu a exousia de poder fazer o julgamento (v. 27a) e que é "Filho do Homem" por meio do pronome pessoal de primeira pessoa - egw,- ocupa, estrategicamente, o centro do discurso. O Filho do Homem é, portanto, o Filho - o revelador - e essa revelação se deu na carne.

A pessoa do "Filho enviado" que assume sua identidade histórica em Jesus é a grande questão desse discurso. A inclusão entre os vv. 19d-30a sublinha a intenção cristológica do texto: o autor se situa no nível da revelação da história da salvação que culmina na revelação da pessoa de Jesus. A revelação de Jesus faz referência à sua origem: O Pai que o enviou. A encarnação do Verbo é uma ideia mestre do Evangelho. Ao retomar a temática da "vontade de Deus" (vv. 30d-30e) ele lança um olhar de fé sobre a ação de Deus na história. Esta ação reveladora será designada a seguir pela palavra "Testemunho" (v. 31a). 


\subsection{5. \\ 5 Momento (vv. 31-39)}

A realidade humana de Jesus é evidenciada como meio escolhido por Deus para realizar sua revelação. A ação testemunhal está, portanto, encaminhada a mostrar que Jesus é a "Palavra reveladora do Pai" 461 . Toda a atividade de Jesus é um testemunho, uma revelação, para indicar a relação que há entre Jesus e o Pai que o enviou. O texto, nos versículos 19d-30e, com detalhes, apresentou o "fazer do Filho" conforme a vontade de quem o enviou; agora, procura mostrar a identidade entre o "homem Jesus" $(5,12)$ que fala (v. 34b) e realiza suas obras (36d), com o Filho enviado (v. 38b) que ouve a voz do Pai (v. 37c) e contempla sua face (v. 37d).

Esta seção tem a função de levar o leitor a refletir sobre a palavra (l egw v. 34b) de Jesus. O que exatamente Jesus "viu" (v. 19e) e "ouviu" (v. 30b) 462 $^{46}$ o que tem a dizer sobre "Aquele" que ele chama de Pai. O tempo que chegou "agora" é o da "Palavra" portadora da profundidade do mistério de Deus, testemunhada por Jesus, o Filho, em suas "obras"; mas porque os ouvintes não creem, a vida que se lhes é oferecida por esta "Palavra" (v. 24b) não é acolhida (vv. 38b-c e 39a-b-c).

\subsection{6. \\ 60 Momento (vv. 40-47)}

Tal "Palavra" é o sim para a vida (vv. 40a-b). O testemunho da Palavra e das obras não foi suficiente para que Jesus recebesse a glória devida (v. 41) e fosse acolhido como enviado do Deus único (v. 44c). A questão, agora (vv. 4047), depende totalmente da aceitação daqueles que ouviram/leram tudo o que foi dito sobre Jesus, o Filho, enviado para revelar o Pai por sua Palavra (v. 45-47). A estratégia do autor por concluir seu discurso pondo em relação Jesus e Moisés, visa acentuar o aspecto revelador que caracteriza a Palavra do Filho. Portanto, quer afirmar ser ele não só o legítimo intérprete das Escrituras, mas seu próprio conteúdo, pois mesmo antes da encarnação a "Palavra" dele era a vida (v. 24; cf.

\footnotetext{
${ }^{461}$ TUÑI VANCELS, O. J., O testemunho do Evangelho de João, pp. 91-95.

${ }^{462}$ Novamente é reativada nos ouvintes a riqueza da tradição dos textos de revelação do Êxodo. Moisés, profeta e intérprete da Torá, havia pedido para ver a glória e YHWH concedeu-lhe ver apenas as costas (Ex 33,23). No texto joanino é afirmado que o Filho é amado pelo Pai (v. 20a) e que ele lhe mostra tudo que faz (v. 20b), inclusive o modo de julgar (v. 30a); não apenas experimenta seu amor, mas é objeto dele.
} 
1,1-4. 14) ${ }^{463}$. "E se não crerdes no que ele escreveu como ireis crer em minhas Palavras"? (v. 47).

\section{4 .}

\section{Síntese dos motivos}

Os motivos que são utilizados na composição do discurso e o desenvolvimento progressivo que cada um recebe em função desse enunciado, fazem parte do conjunto de estratégias de construção de sentido, necessárias para esclarecer aspectos particulares relacionados com a compreensão do motivo central. Este vai sendo demonstrado a partir do v. 19d, versículo a versículo, do ponto de vista da eternidade do Pai, até atingir a concretude da encarnação (v. 30a). Nesse ponto, o mesmo enunciado que introduziu a pessoa do Filho (v. 19d) é retomado do ponto de vista histórico (v. 30a), para mostrar "o rosto" deste Filho - egw, - que assumindo sua condição humana atua na história trazendo a vida eterna por sua Palavra (vv. 31-39; cf. v. 24) e, consequentemente, espera ser acolhido como o legítimo intérprete da revelação do Pai (vv. 40-47).

$\mathrm{Na}$ análise dos motivos ficou evidente também o modo como o autor projetou a organização do texto, em torno do plano do enunciado do v. 19d: “ouvdunatai o’ ui òj poi ei h aff eàutoul ouden”, tomando por objeto o próprio texto, "o ato de Jesus dizer-se Filho". A Palavra pronunciada por Jesus no ato inicial de sua fala sustenta todo o discurso, que se desenvolve, por meio dos seis motivos, segundo os quais o assunto é aprofundado em todas as dimensões, e se chega a comprendê-lo em sua totalidade. A organicidade que viabiliza essa “centração" está vinculada à interdependência semântica das funções que cada um dos motivos apresenta em relação ao todo. A centralidade refere-se à dimensão do conteúdo em pauta, caracterizando-se pelo foco na relação Pai - Filho, revelada por sua Palavra que se fez carne, cuja relevância eleva-a à categoria de assunto central.

A sequenciação dos motivos demonstrou que não há deslizamento de sentidos e que o autor tem um amplo domínio não só de habilidades

\footnotetext{
${ }^{463}$ Cf. A temática de que Moisés escreveu sobre Jesus na Lei já aparece no início do Evangelho em 1,45, em forma de título dado a Jesus, embora, aí se acrescente que "os profetas" também escreveram sobre "Ele".
} 
linguísticas, mas também de uma série de estratégias de ordem sócio-cognitiva, cultural, religiosa e teológica que atuam no âmbito da própria atividade discursiva de modo unitário. 


\section{6 \\ O tema unificador do discurso de Jo $5,19-47$ e sua relevância no contexto do Evangelho.}

\section{1. A função pragmática do texto}

A disposição da matéria temática do discurso em um número limitado de motivos sublinha a relevância e interdependência de ambas as categorias - motivo e tema - no modo de tratar o discurso. A demonstração da unidade e unicidade de ação entre o Filho e o Pai que é estrategicamente desenvolvida, com argumentos teologicamente construídos, tem a finalidade de fundamentar a revelação da atuação "da Palavra de Deus" (Jo 1,1) "que era Deus" (cf. 1,1c), e que continua "até agora" $(5,17)$ sua ação criadora e salvadora $(5,8 ; 1,14)$.

A lógica da organização dos motivos - com sua estratégia de articular na primeira metade do discurso (vv. 19-30) os argumentos que esclarecem a verdade da "relação Pai-Filho" ${ }^{464}$, e na segunda metade, a realidade histórica do "Filho" na pessoa de Jesus (vv. 31-47) que realiza as obras do Pai (v. 36) - contribui para delinear a arquitetura unitária do discurso como em um espelho: uma face revelando a outra: o Filho enviado pelo Pai para agir em favor da humanidade (vv. 19-30; cf. 3,16) é o homem Jesus (vv. 31-47; cf. 5,12), a Palavra preexistente que se fez carne $(1,14)$.

Além da estratégica coordenação das ideias construtoras de sentido do discurso, que torna mais clara e orgânica a exposição do argumento central, a hierarquização dos motivos contribui, sobremaneira, para aumentar a expectativa do leitor e criar melhor condição de receptividade apontando, assim, para a influência do ouvinte na gênese do texto. $\mathrm{O}$ autor deixa claro que pretende exercer sobre seus leitores (o implícito e o do texto), uma série de ações, visando intervir na recepção do seu discurso. Marcas dessas ações se manifestam no texto, por meio de atos linguísticos expressos na relação entre locutor e interlocutores evidenciando, assim, o sentido pragmático do texto.

${ }^{464}$ Conforme já foi analisado, com exceção dos vv. 24 e 30. 
Constatada a relevância do leitor para o qual o texto foi escrito, deve-se procurar não apenas identificá-lo, mas também perguntar pela relação que se estabelece entre os parceiros textuais, a situação comunicativa que suscitou esse discurso e os leitores reais.

\subsection{1.}

\section{A relação locutor/interlocutores}

Enquanto o locutor, durante todo o discurso, realiza seus atos de fala com muita propriedade e autonomia, demonstrando pleno domínio da situação, os interlocutores desse texto (vv. 19-47) nunca falam e nem tampouco estão nomeados. No entanto, eles são constantemente convidados a interagir por meio da "escuta da palavra" que lhes é dirigida (e lhe mostra tudo... v. 20b; para que vos admireis... v. 20e; vós enviastes..., v. 33a) e com a qual eles partilham um conhecimento comum (vós perscrutais...39a; vós julgais... 39b; não penseis v. 45c).

O desnível no tratamento dispensado às duas partes - locutor e interlocutores - que interagem no discurso é estratégico. Não deixando que haja espaço para controvérsias ou para polêmicas, o autor quer destacar a superioridade do locutor e a excelência de sua comunicação que porta uma especial revelação.

O locutor é identificado pelo próprio texto com Jesus (cf. v. 19a), mas quem são seus interlocutores?

\section{a. A identidade dos interlocutores}

O texto antecedente ao discurso (5,1-18), apresenta uma situação comunicativa na qual "oi 'Voudai $\not d "$ " (os judeus) fazem "acusações" a Jesus $(5,18)$ e às quais ele responde no texto seguinte (vv. 19-47), permitindo, assim, que os interlocutores do discurso possam ser identificados com esses acusadores, a quem o narrador de 5,1-18 chama de "os judeus". Quem são esses identificados como “os judeus”? Indivíduos, ou grupos, ou nação? Qual sua identidade real e sua função (papel) no texto?

O uso do termo "judeu" no Novo Testamento é genérico. Pode se referir à raça judaica, às pessoas de Jerusalém, às autoridades judaicas (governadores, sumo sacerdotes, fariseus, saduceus etc), aos judeus da Judeia (e não galileus e 
samaritanos) e aos judeus da diáspora palestinense e da diáspora helenista ${ }^{465}$. O certo é que é um vocábulo muito significativo no processo da construção da identidade cristã para acentuar a continuidade entre a teologia judaica e a cristã.

No Evangelho de João, o termo "judeu" também não tem um sentido unívoco, tornando-se difícil identificar implicações exclusivamente de caráter positivo ou negativo. Impressiona a frequência com a qual este termo aparece nesse Evangelho ${ }^{466}$ e sempre determinado pelo artigo "os", constituindo-se na expressão "os judeus" 467 .

Para o evangelista, existem os judeus crentes. Muitos textos o afirmam explicitamente (cf. 8,$31 ; 10,42 ; 11,45 ; 12,11$ ), e é o único Evangelho a afirmar que "a salvação vem dos judeus" (cf. 4,22) 468 e que Jesus é "judeu” (cf. 4,9), bem como, também, é o único a chamar os adversários de Jesus de "os judeus" (cf. $5,18)^{469}$. O refrão "os judeus o queriam matar" $(5,18.7,1$. 19. 25; 8,37. 40; 11,53)

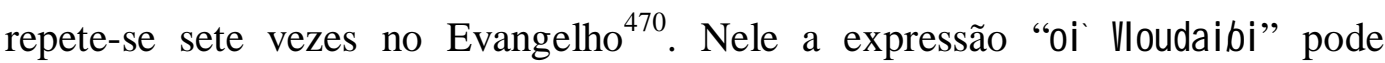
considerá-los como pertencentes aos diversos grupos judaicos: ora são identificados como sacerdotes e levitas $(1,19)$, fariseus $(1,24 ;)$; ora faz distinção entre judeus e fariseus (2,18. 20 os judeus; 4,1 os fariseus; 7,32 os fariseus; fariseus e os sumos sacerdotes 18,3), ora os considera juntos ${ }^{471}$, além de identificá-los também com as autoridades religiosas ${ }^{472}$ e em 18,3 "os judeus" proprietários dos criados são os sumos sacerdotes e os fariseus, que são nomeados com a mesma expressão.

\footnotetext{
${ }^{465}$ MANNS, F., L'Évangile de Jean à la Lumière du Judaïsme, Studium Biblicum Franciscanum, Analecta 33, 1991, p. 177.

${ }^{466}$ Examinando-se a presença da expressão no Evangelho, pode-se contar cerca de setenta ocorrências.

${ }^{467}$ Como foi constatado na análise dos aspectos sintáticos, o autor dá muita relevância aos termos que veem determinados pelo artigo.

${ }^{468}$ Em "a salvação vem dos judeus" $(4,22)$, judeu tem sentido religioso de povo da aliança, povo do qual vem o Messias, cuja tradição se encontra no Gn 28,16: "Na verdade Deus está neste lugar e eu não sabia". À luz da referência a Jacó-Israel, a alusão a Gênesis não é inesperada. Os judeus estão dentro do curso da revelação salvadora de Deus; eles conhecem aqueles que adoram, "pois a salvação vem dos judeus". Eles são o veículo daquela revelação, a matriz histórica da qual aquela revelação emerge. A salvação messiânica que Jesus traz não se compreende senão a partir da tradição de Israel. Jesus é o ponto de chegada da esperança de Israel e o ponto de partida dos tempos escatológicos. Cf. CARSON, D. A., O comentário de João, São Paulo: Shedd Publicações, 2007, p. 224.

${ }^{469}$ ASHTON, J., Comprendere Il Quarto Vangelo, Città del Vaticano: Ed. Vaticana, 2000, p. 140. Cf. nota 22.

${ }^{470}$ MANNS, F., op. cit., p. 172.

${ }^{471}$ Conferir as citações: 5,1. 10. 15. 16. 18; 6,41. 52; 7,1. 11. 13. 15; 7,35; 8,13//8,22; 8,48. 57; 9,13. $16 / / 9,18 ; 9,22 / / 9,40 ; 10,19$. 24. 31. 33; 11,31. 36. 46. 47. $54 / / 47.57 ; 18,20$.

${ }^{472}$ Conferir: 12,$42 ; 18,14 ; 18,31 ; 18,38 ; 19,6 / / 19,7 ; 19,14 ; 19,38$.
} 
Porém, em grande parte do Evangelho a expressão “os judeus" adquire uma perspectiva particular. Por exemplo, em 7,1, refere-se ao povo da Judeia; no entanto, ela, geralmente, quer identificar os líderes judeus, especialmente os de Jerusalém e da Judeia (cf. 1,19). Nem todos os líderes judeus são identificados negativamente, entre os quais Nicodemos e José de Arimateia (cf. 3,1ss; 7,50; 19,38-42 $)^{473}$. As afirmações consideradas neutras como "a Páscoa dos judeus"; "a festa dos judeus"; "as purificações dos judeus", apesar de não terem um explícito conteúdo polêmico, elas supõem, através do genitivo "dos judeus" uma conotação muito importante de diferenciação das práticas que chegam a marcar uma separação (cf. Jo 2,6. 13). Como se vê, a expressão "os judeus" do Evangelho de João constitue um amálgama, compreendendo as autoridades, os sumos sacerdotes e os fariseus. A própria diversidade de usos do termo "os judeus" exclui interpretações que jogam o evangelista contra todos os judeus de seus dias; porque, nesse caso, as ocorrências que são positivas ou ditadas pela geografia da Palestina pouco fariam sentido.

Ashton $^{474}$, diz que Bultmann considera os judeus como representantes dos descrentes, não se referindo, portanto, ao povo da Judeia, nem às hostilidades entre os galileus e ou samaritanos e judeus, pois são referidos do ponto de vista da fé. Este ponto de vista é assumido, também, por Perkins Pheme, no seu comentário ao Evangelho de $\mathrm{João}^{475}$. Porém, essas afirmações, encontram opositores.

Para Ashton ${ }^{476}$, o Evangelho apresenta uma profunda ambivalência, uma estranha relação de amor e ódio, que inclusive levou C. K. Barret a notar que o Evangelho de João é mais judeu que antijudeu. Na afirmação de Barret o termo “judeus” refere-se aos costumes e cerimônias, modo de expressar-se e de pensar. Essa distinção, naturalmente, não resolve o enigma: agudiza-o. Carson ${ }^{477}$ sugere ser a expressão um rótulo que com frequência significa gente da Judeia ou líderes judeus (cf. 7,1-3) na Judeia, e ele é de opinião que o único contexto em que a

\footnotetext{
${ }^{473}$ CARSON, D. A., op. cit., p. 142.

${ }^{474}$ Conforme Ashton a função dos judeus no Evangelho, segundo Bultmann, era de representantes dos descrentes; do ponto de vista da fé; não fala do estado empírico do povo hebraico, mas de sua própria natureza: representante da dureza do coração em crer. Muitos estudiosos discordam. Cf. ASHTON, J., op. cit., pp. 137-138.

${ }^{475}$ PHEME, P., Il Vangelo secondo Giovanni In BROWN, R.; FITZMYER, R. A.; MURPHY, R. F., Nuovo Grande Commentario Biblico, [S.I.]: Queriniana, 2002, p. 1242.

${ }_{476}^{476}$ ASHTON, J., op. cit., p. 134.

${ }^{477}$ CARSON, D. A., op. cit., p. 141.
} 
diversidade de usos faz sentido é o contexto do Jesus histórico. No entanto, Ashton $^{478}$ pensa que essa problemática da identificação dos judeus não se soluciona sem que se tente situar a história do Quarto Evangelho no pensamento judaico. Também para Manns ${ }^{479}$, a importância dos judeus nesse Evangelho se explica, em parte, pelo contexto histórico do Quarto Evangelho e reflete a tradição desenvolvida pelo judaísmo do século primeiro.

Isso não significa que a escolha da terminologia pelo evangelista não tenha sido influenciada por seu próprio contexto no tempo da escrita. A designação parece referir-se a um particular grupo religioso que não pode ser identificado, de modo geral, com os fariseus; no entanto, quer indicar uma diferença religiosa ${ }^{480}$. $\mathrm{Na}$ opinião de Carson $^{481}$ o evangelista está interessado em evitar que os judeus da diáspora cometam os mesmos erros que os judeus palestinenses, e, portanto, não é de surpreender que ele usasse uma linguagem forte para denunciar "os judeus". Ele bem poderia ter interesse em diferenciar os judeus comuns de (pelo menos) alguns de seus líderes.

\section{b. Os judeus-interlocutores do Evangelho}

O Evangelho não oferece nenhuma resposta à questão da fonte de hostilidade entre o evangelista e os judeus ${ }^{482}$. Há indícios, conforme Manns ${ }^{483} \mathrm{e}$ Ashton $^{484}$, de que a expressão "os judeus" esteja em função das estratégias

\footnotetext{
${ }_{478}^{478}$ ASHTON, J., op. cit., p. 133.

${ }^{479}$ No judaísmo do fim do primeiro século, não mais existiam os sumos sacerdotes, os dirigentes eram os fariseus. Cf. MANNS, F., L'Évangile de Jean à la Lumière du Judaïsme, p. 166.

${ }^{480}$ As acusações, conforme 5,18, são de caráter religioso. Segundo Manns é no interior de um grupo judeu que "os judeus" podem designar simbolicamente "o inimigo". Nos profetas se encontra eco de oráculos contra Jerusalém na própria comunidade judaica de Jerusalém (cf. Is 8,6ss; Jr 26,4-6; Ez 2,3-5; Jl 2,2 etc). Em Qumran, nos escritos 6QD, a expressão "os judeus" designam aqueles que se encontram em Jerusalém como os adversários obstinados dos essênios (QCD 4,3.11 e 7,10-21; 14,1; Judá simboliza o sacerdote oficial de Jerusalém hostil aos essênios). Um texto de Qumran que polemiza claramente contra os fariseus é o Pesher de Nahum (4QpNah). Aí, eles acusam os fariseus de serem exegetas que seguem o caminho da facilidade. Os convertidos de Israel saíram do país de Judá. A casa de Judá é destituída dos membros da Aliança. A apresentação esquemática dos fatos não é sem ligação com o que os textos de Qumran afirmam dos fariseus. Cf. MANNS, F., op. cit., p. 182 et seq.

${ }^{481}$ Cf. CARSON, D. A., O comentário de João, p. 92.

${ }^{482} \mathrm{~A}$ denúncia dos judeus frequente e veemente no Evangelho não encontra sua mais profunda motivação nem nos preconceitos raciais nem em sectarismo patológico, mas na firme convicção de que a salvação, para judeus e gentios igualmente, encontra-se no Messias anunciado pelas Escrituras judaicas, um Messias cujas declarações não podem ser ignoradas sem perigo. Cf. Ibid., p. 225.

${ }^{483}$ MANNS, F., op. cit., p. 182.

${ }^{484}$ Para Ashton na narrativa de 5,1-18, os judeus seriam uma figura literária. ASHTON, J., Comprendere Il Quarto Vangelo, p. 133 et seq.
} 
literárias do autor. Por exemplo, no Evangelho de João, a "Galileia" é o símbolo do acolhimento favorável reservado ao Messias e da revelação do Messias (cf. 4,45). É em Caná da Galileia que Jesus revela sua glória $(2,11)$, cura o filho do funcionário real $(4,46-50)$ e se revela pela terceira vez após a ressurreição $(21,1$ 2). O verdadeiro israelita, Natanael $(1,47)$, é de Caná. A Samaria também está aberta à mensagem de Jesus $(4,42)$.

No texto de Jo 5,1-18, a expressão aparece cinco vezes $(5,1.10 .15 .16 .18)$. Em 5,1, está no genitivo, referindo-se ao contexto cronológico-religioso do calendário das festas judaicas: “eòrth. twh Voudai un”" (festa dos judeus); porém

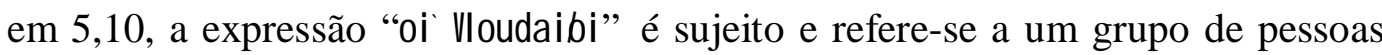
que se encontravam nas cercanias do Templo ou dentro dele e que interpelam o homem curado $(5,15)$. O motivo de tal interpelação é o agir de Jesus em dia de sábado (cf. 5,16. 18).

Os Evangelhos Sinóticos trazem controvérsias a propósito do sábado entre Jesus e os fariseus (cf. Mt 12,2), porém as cinco controvérsias que o Evangelho de Marcos traz (cf. Mc 2,1-3,6), na qual os opositores de Jesus são identificados com os escribas e os fariseus, e que terminam com a decisão de prender Jesus, apresentam muitas afinidades literárias com o relato de Jo 5,1-18, especialmente Mc 2,9 (cf. Jo 5,8// Mc 2,9; Jo 5,9// Mc 2,9). A maior diferença trazida por João consiste no motivo da ruptura do repouso sabático e da justificação que Jesus dá de sua maneira de agir. Para Manns, esse relato de 5,1-18 seria a síntese dessas controvérsias na qual o evangelista substitui "os fariseus" pelo termo genérico "os judeus" 485 .

A questão em Jo 5 não se situa mais, como na tradição sinótica, em discussão de natureza jurídica, no "modo" como Jesus observa o sábado, mas na "origem" de seu agir no sábado: como Deus, a quem ele chama "meu Pai". Tal afirmação implica a explicitação de sua filiação divina, comprometendo, assim, o princípio de um único Deus. A especial relação de Jesus com Deus se explica

\footnotetext{
${ }^{485}$ Uma lista de comparações das tradições comuns, entre os Evangelhos de João e os Sinóticos permite dizer que os judeus de João correspondem aos fariseus e aos sumos sacerdotes dos Sinóticos. Nos contatos entre o Evangelho de João e a tradição sinótica se identifica os fariseus dos Evangelhos sinóticos com os judeus de João. Enquanto em Jo 6,41. 52 são os judeus que murmuram em Mc 8,11 são os fariseus. Em Mt 16,1 são os fariseus e os saduceus. Em Jo 10,24-25 são os judeus que perguntam: "Se tu és o Messias, dize-nos abertamente". Os sinóticos situam essa questão no diálogo do processo contra Jesus (cf. Lc 22,67; Mt 26,63; Mc 14,61) e são os sumos sacerdotes e os representantes do sinédrio que o interrogam. Cf. MANNS, F., L'Évangile de Jean à la Lumière du Judaïsme, p. 175.
} 
melhor sob um transfundo judaico. A afirmação de Jesus como a "Palavra divina" ativa na criação (cf. 1,3) reflete a descrição da Sabedoria de Deus que participa da criação e desce para estar com os seus que não a receberam $(1,10-11)^{486}$.

Um olhar sobre o discurso, especialmente, nos vv. 23a-b-c-d-e, mostra que o autor estava preocupado com o efeito da avaliação negativa que a Sinagoga fazia de Jesus e daqueles que o seguiam (vv. 40a-b). Talvez ele tenha compreendido os judeus não-cristãos, no mínimo, como uma voz potencialmente significativa para seus ouvintes - uma voz cuja influência ele não negaria. A desconfiança, ou mesmo o temor de que as sinagogas locais estivessem se tornando mais rigorosas em suas tentativas de reconduzir os membros desviados de sua raça para o reto caminho da observância da Torá, abandonando as "aberrantes crenças

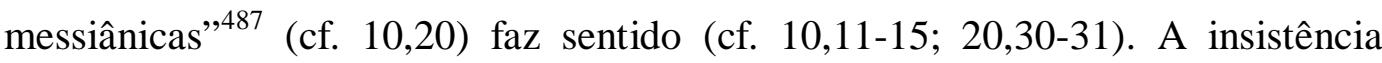
sobre receber glória no v. 41: "Glória, não a recebo dos homens" pode dar a entender que os cristãos careciam de uma imunidade especial com relação à opinião dos judeus não cristãos, e ainda, mais especificamente, quanto ao problema de ter de optar entre honrar Jesus e ser honrado, ou aclamado na sinagoga (cf. 12,10b. 42).

Brown $^{488}$ pressupõe que esses judeus (as autoridades religiosas de Jerusalém hostis a Jesus) eram os ancestrais espirituais dos "judeus de seu próprio tempo", que estavam pressionando os judeus-cristãos tanto a esconder quanto a renunciar a suas convicções acerca de Jesus, como o Messias, sob o risco de excomunhão da Sinagoga (cf. 12,42s).

Já desde as cartas de Paulo ${ }^{489}$ se testemunha essa realidade. Ele chama os membros cristãos judaicos que se opõem ao seu "evangelho" de "os judeus" como, por exemplo, em Gl 2,13. Também o Livro do Apocalípse manifesta a mesma problemática (cf. Ap 2,9-10; 3,9). O termo pode mesmo designar círculos cristãos judaicos hostis, não à comunidade enquanto tal, mas à cristologia da

\footnotetext{
${ }^{486}$ PHEME, P., Il Vangelo secondo Giovanni In BROWN, R.; FITZMYER, R. A.; MURPHY, R. F., Nuovo Grande Commentario Biblico, p. 1241.

${ }^{487}$ DESILVA, A. D., A esperança da glória, Reflexões sobre a honra e a interpretação do Novo Testamento, São Paulo: Paulinas, 2005, p. 130.

${ }^{488}$ BROWN, R., El Evangelio según Juan, v. 2, Madrid: Cristiandad, 1979, p. 70.

${ }^{489}$ As cartas de Paulo, especialmente a Epístola aos Gálatas fazem referência a um grupo de cristãos judeus "circuncisos" (Gl 2,12) que "está querendo corromper o evangelho de Cristo" (Gl 1,7) a quem ele chama de "intrusos, esses falsos irmãos que se infiltraram para espiar a liberdade que temos em Cristo Jesus, a fim de nos reduzir à escravidão...” (cf. Gl 2,4).
} 
filiação divina ${ }^{490}$. O fato é que a caracterização do rótulo “os judeus" está relacionada com o tempo em que o Evangelho foi escrito, e envolve questões peculiares da comunidade Joanina, como a ausência de fé na identidade de Jesus, como a Palavra de Deus que se fez carne, em cuja incredulidade o evangelista via ainda a possibilidade de conversão ${ }^{491}$.

\section{c. A relação locutor/interlocutores em sua situação comunicativa}

Diferente do rabino fariseu, mestre das Escrituras ${ }^{492}$, que precedia sua fala com a introdução: "O Santo - bendito seja ele", Jesus se apresenta como aquele que fala em primeira pessoa: "eu vos digo"493. Fala como homem que reivindica a própria autoridade de Deus. Fala como homem, como se estivesse ao lado de Deus, para além da função de mestre ${ }^{494}$. Essa sua atitude soberana, na qual se coloca acima da Torá ${ }^{495}$, é entendida como uma autoexaltação independente, uma rebelião da criatura contra o Criador e Senhor do mundo ${ }^{496}$. A consequência principal tirada pelos interlocutores, não é a transgressão do repouso sabático, à

\footnotetext{
${ }^{490}$ Ashton sugere que a controvérsia com os judeus sejam de um período no qual os grupos judeus e cristãos mantinham ainda diálogo ativo um com o outro. A rejeição seria dirigida a Jesus mesmo, sempre em relação a sua especial revelação. Cf. ASHTON, J., Comprendere Il Quarto Vangelo, p. 138.

${ }^{491}$ PHEME, P., op. cit., p. 1242.

${ }^{492}$ Os mestres fariseus eram os doutores da Lei e desempenhavam a função de mediadores no estudo da Torá. A Torá representava Deus e sua soberana vontade. Cabia à transmissão dos conhecimentos um papel relevante e eles eram chamados de mestres.

${ }^{493} \mathrm{O}$ autor quer fazer compreender que as palavras de Jesus, sua interpretação das Escrituras, sejam reconhecidas, também e com evidência como Palavra de Deus. O que ele diz é o que o Pai fala. Afinal, a Torá oral precede à escrita. Da mesma maneira o Evangelho. Antes de ser consignado por escrito foi anunciado e pregado (1 Cor 15,1-2). Esse Evangelho oral foi recebido pelos crentes como Palavra de Deus. Foi essa visão da Torá que tornou possível o anúncio do evangelho. É importante valorizar o elo entre o Evangelho e a Torá oral dos fariseus. Cf. COLLIN, M.; LENHART, P., Evangelho e tradição de Israel, São Paulo: Paulus, 1994, pp. 34; 7.

${ }^{494}$ Há um ponto fundamental da teologia farisaica cuja importância positiva supera a controvérsia com os sadudeus ou qualquer outro grupo: é a existência da tradição de Israel, recebida e transmitida como Palavra de Deus, que os fariseus chamam de Torá oral. Os fariseus pretendem que a tradição, quando recebida e transmitida em certas ocasiões, é Torá. Palavra de Deus igual a das Escrituras. Mishná: conjunto da Torá oral, o que é ensinado através da tradição oral. A publicação da Mishná mais antiga não é anterior ao ano de 219 d. C. Fez-se a partir do testemunho oral (deve-se, pois, confiar na oralidade das tradições recebidas através da relação mestrediscípulo). O Talmud da Babilônia, a redação final, data do século V. A oralidade culmina na prática dos mandamentos que manifesta a vontade de Deus. Cf. Ibid., pp. 7; 14.

${ }^{495}$ A Torá era discutida entre grupos, razão por que a argumentação e a crítica ética tiveram uma função polêmica, agravada em consequência da interpretação da história, igualmente discutida, e da ética da situação, baseada nela. Um problema constantemente crescente dessa devoção à Torá foi, de um modo geral, a necessidade de um estudo geral da Torá. E no cristianismo primitivo, por causa de sua mensagem, houve naturalmente também novos pontos de vista em relação à ética. Cf. MAIER, J., Entre os dois Testamentos, história e religião na época do Segundo Templo, São Paulo: Loyola, 2005, p. 228.

${ }^{496}$ Cf. Ibid., p. 230.
} 
qual não há nenhuma referência no discurso ${ }^{497}$, mas a pretensão inaudita de ser o "Filho de Deus"; pois Jesus não argumenta a partir da necessidade do enfermo, mas a partir de sua relação com Deus, a quem chama "meu Pai".

Consoante Schnackenburg ${ }^{498}$, a afirmação de 5,17 tem como pano de fundo o ponto de vista rabínico, do mesmo modo que em 7,22s, que, retomando uma tese judaica a desenvolve com uma argumentação rabínica ${ }^{499}$. A disputa supõe a compreensão da comunidade cristã joanina mais evoluída que a da exposição sinótica, pois a formulação da acusação $(5,18)$ com el uen (dissolvia o sábado) delata o ponto de vista posterior, segundo o qual Jesus não só deixava de lado o preceito do sábado em alguns casos, mas eliminava em sua raiz o sábado judeu com suas prescrições ${ }^{500}$. A imagem de continuidade do trabalho criativo de Deus no sábado implicaria fortemente a divindade de Jesus. Do ponto de vista de 7,22s, onde Jesus descreve este acontecimento como uma cura total da pessoa no sábado, em uma alusão à criação, provavelmente implica especificamente a criação da humanidade em Gn $1,26^{501}$.

Em grande parte as discussões intrajudaicas se davam em torno da reta compreensão e da praxe certa da vontade de Deus. Os debates de Jesus com os fariseus são debates internos de uma mesma escola, e são tanto mais sérios por todos saberem que se trata de responsabilidade comum da exata interpretação das

\footnotetext{
${ }^{497}$ Neste discurso não aparecem, nenhuma vez, as palavras: Lei, Torá, Messias, sábado.

${ }^{498}$ No NT se referem a uma ética especificada a partir do anúncio do Reino de Deus, cujas declarações já são cristológicas, no sentido de transferirem para o Cristo crucificado e ressuscitado o simbolismo da Torá e sua função de "caminho de salvação", bem como as funções de diversos papeis e figuras. Paulo designa o Cristo, consequentemente como o fim da Lei (como caminho de salvação). Essa designação devia ser interpretada não tanto à luz de funções "messiânicas", mas, sobretudo, com relação a essa função de suplantar a lei como caminho de salvação; nela está a diferença entre cristianismo e judaísmo. Cf. Ibid., p. 226; 230.

${ }^{499}$ Conforme Manns no estudo das raízes judaicas do Evangelho faz-se necessário discernir o que ele deve ao seu meio - em nível de sua formação e de seu conteúdo, para melhor pôr em evidencia a novidade da mensagem de Jesus. Os Pais da Igreja que aceitaram os princípios de exegese cristológica do AT têm recorrido frequentemente à exegese rabínica. Ele cita G. Vermes que reconhece que a literatura rabínica permanece a fonte principal da reconstituição do pano de fundo dos Evangelhos e tem-se que explorá-la corretamente. Cf. MANNS, F., L'Évangile de Jean à la Lumière du Judaïsme, p. 188.

${ }^{500}$ Cf. SCHNACKENBURG, R., El Evangelio según San Juan, v. 2, Salamanca: Herder, 1980, pp. 138-139.

${ }^{501}$ Segundo Keener, se então o pano de fundo é o Pai e o Filho trabalhando juntos na criação aqui pode ser dito "Façamos... à nossa imagem" (Gn 1,26). O "dar a vida" (v. 21c) então pressuporia a ressurreição (5,24-25), uma idéia para a qual o discurso frequentemente retorna (cf. v. 24; 26b; 40a-b). A ressurrreição viria no último dia (cf. vv. 29b-29c; 6,39. 40. 44. 54; 11,24; 12,48), uma idéia que pode invocar o sentido escatológico do sábado que aparece em algumas fontes judaicas, embora último dia possa também ser perfeitamente inteligível sem tal alusão. Cf. KEENER, C. S., The Gospel of John, A Commentary, v. 1, Massachussetts: Hendrickson Publishers, 2005, p. 649.
} 
Escrituras e que está em jogo a Torá ${ }^{502}$. A Torá era considerada a vontade de Deus incondicionalmente obrigatória, de cujo cumprimento ou violação se acreditava que dependia o destino do povo de Deus e, afinal, de toda a humanidade e de toda a criação. A Torá é, portanto, tarefa imposta aos eleitos, como vontade obrigatória; ela é "Lei", mas de um alcance que não compete a nenhuma outra lei; portanto, ela não é de natureza apenas jurídica e moral. Ela é a "Torá da vida"; quem a recusa escolhe a morte (assim já em Dt 30,15ss).

Conforme J. Maier ${ }^{503}$ a trama essencial e primitiva dos debates de Jesus no Evangelho de João não se encontra nos conflitos. Aquém e além das violentas polêmicas sobre a "Vontade de Deus", o "Filho do Homem e sua função de juiz"; "o Filho de Deus"; "o agir divino"; o "Profeta escatológico"504, as consonâncias dos ensinamentos evangélicos com a tradição farisaica são numerosas e profundas. A mais radical é precisamente uma compreensão comum da Torá como tradição transmitida de mestre a discípulo, antes mesmo de sua referência à Escritura $^{505}$.

Para os cristãos é necessário saber como Jesus recebeu e transmitiu a Torá. Jesus nasceu, viveu, rezou como judeu - seja qual for a profundeza insondável de seu próprio acesso ao Pai -, frequentou o Templo, participou dos sacrifícios, celebrou as festas judaicas, era assíduo ao serviço da Sinagoga ${ }^{506}$. É significativo

\footnotetext{
${ }^{502}$ A Torá é a realidade que domina e dirige a vida do povo judeu no tempo de Jesus e das primeiras comunidades cristãs. É o ensinamento que vem de Deus, que faz conhecer Deus e que conduz a Deus. MAIER, J., Entre os dois Testamentos, p. 226.

${ }_{503}$ Ibid., pp. 220-223.

${ }^{504} \mathrm{Na}$ época do NT o profetismo já não existia no judaísmo como profissão regular e organizada. Foi precisamente partindo do AT (Dt 18,15-18), que nasceu a esperança de um profeta escatológico. Seria um novo Moisés ou um Elias redivivo (ecos dessa profecia se encontra em Qumran, Ml 3,1-4 referindo-se a 2 Rs1-12). A tradição de Elias não está presente em João e sim a de um profeta escatológico de caráter mosaico (Cf. 1,45; 6,14; 7,40). As autoridades se recusam a reconhecer Jesus como profeta porque vem da Galiléia $(7,52)$, mas para a comunidade ele é o profeta: Como Moisés é encarregado de revelar o nome inefável de Deus aos homens $(17,6)$; porém ele pode fazê-lo muito melhor que Moisés, posto que leva, nele, esse nome. Em 1,14. 16-18 Jesus é descrito como a nova aliança em referência a Ex 33-34; porém sua superioridade sobre Moisés $(1,17)$ provém de que ele permanece no seio do Pai e que só ele pode revelar aos homens os segredos do Pai $(1,18)$. Também o Maná em 6,31-58 e a serpente que ele elevou no deserto em 3,14 são suplantados por Jesus. Nestes dois casos, João insiste em que o Dom de Jesus é finalmente idêntico à sua pessoa. Por isso sua crucifixão proporciona a vida eterna, que é, qualitativamente superior a um elemento perecedouro (o maná) e a uma cura temporal (a serpente do deserto). Por tudo isso o crente joanino tem ante si a alternativa de ser discípulo de Moisés ou de Jesus $(9,28)$. Essa era ao menos a alternativa que os judeus punham ante os cristãos joaninos. Pior é que estavam equivocados ao crer que aceitar a Jesus era automaticamente rechaçar Moisés. Não se davam conta de que Moisés era na realidade uma testemunha de Jesus $(5,45-47)$. Cf. SCHNACKENBURG, R., op. cit., pp. 135-140.

${ }_{505}$ Cf. COLLIN, M.; LENHART, P., Evangelho e tradição de Israel, pp. 7; 14.

${ }^{506}$ Cf. Ibid., p. 10.
} 
que Jesus não tenha sofrido da parte dos chefes do povo nenhuma crítica a respeito desses pontos. Jesus se inscreve em seu domínio teológico e ensina a novidade de seu Evangelho na plena continuidade da tradição que tanto prezavam. A singularidade de sua prática e ensinamento, da unicidade de sua pessoa de Messias e, especialmente, de "Filho" que vem cumprir as Escrituras e revelar a face do Deus de Israel, nosso Deus, constitui o centro da novidade trazida por Jesus. A Torá oral de Israel e o Evangelho são, do ponto de vista cristão, uma mesma Palavra de Deus: raiz e fruto que não têm existência, a não ser em sua continuidade fundamental querida por um Deus cujas promessas e desígnios são irreversíveis $^{507}$.

Os cristãos creem que a Torá é o Cristo ${ }^{508}$. Os fundamentos mais importantes para essa compreensão foram fornecidos pelas tradições sapienciais, cuja concepção de uma ordem imanente ao mundo era equiparada à Torá, até que essa finalmente, em forma personificada, foi totalmente identificada com a Sabedoria (Sir 24,23). Como vontade de Deus, como Sabedoria do Criador, a Torá é Lei divina mundial e universal ${ }^{509}$. A Sabedoria fora identificada mais e mais com a Torá, a vontade de Deus revelada.

O cume do desenvolvimento da cristologia da filiação vem a João por obra da cristologia sapiencial. As expressões sapienciais do AT (cf. Pr 8,22s; Sir 24,1ss; Sb 7-9) chegam a ser expressões da Palavra feita carne e o homem Jesus se identifica com a "Palavra" que desceu do céu $(1,14)$. O Cristo Joanino desceu do céu para fazer a vontade do Pai que o enviou (v. 30a; 6,38) e como "Logos encarnado" sabe que vem de Deus e volta para Deus (13,3). Apresentar Jesus como o Filho, o "enviado", que fala a Palavra definitiva do Pai, o único que revela Deus, era solapar o conteúdo, por excelência, da doutrina judaica ${ }^{510}$.

\footnotetext{
${ }^{507}$ A Torá é mais do que uma ordem para a vida e a sociedade, sua realização significa o Reino de Deus, ela leva à consumação da história de Deus com seu povo; ela é, quando devidamente interpretada e aplicada, o caminho da salvação simplesmente. A Torá e a história: O cumprimento da Torá e a consumação da história formavam no judaísmo, uma unidade indivisível, constituindo, nesta conexão, o ponto mais focalizado das controvérsias intrajudaicas a respeito da verdadeira aplicação da Torá. Cf. MAIER, J., Entre os dois Testamentos, p. 227.

${ }^{508}$ Joseph Ratzinger em sua obra "Jesus de Nazaré" a esse respeito diz: "Na transfiguração os apóstolos experimentam que Jesus mesmo é a Torá viva. Toda a Palavra de Deus" (Mc 9,7). Cf. RATZINGER, J., Jesus de Nazaré, São Paulo: Planeta, 2011, p. 20.

${ }^{509}$ MAIER, J., op. cit., p. 228.

${ }^{510}$ Cf. O eco do último discurso de Moisés em Dt 32,1-47 está ressoando no discurso de 5,19-47: a palavra que Moisés proclama é "a minha doutrina"; "minha palavra" (Dt 32,1-2); Em 32,4 fala sobre o julgamento de Deus: "Deus é justo em seu agir"; em 32,6: "Não é ele teu Pai, teu Criador?"; v. 32,39: "Sou eu que mato e que faço viver"; E acrescenta no v. 47: "A palavra da Lei
} 
O Quarto Evangelho, como é de amplo conhecimento, vem largamente influenciado pela experiência traumática da expulsão da Sinagoga (cf. 16,2) ${ }^{511}$. Ele foi testemunha da cisão dolorosa que se produziu no seio da Sinagoga e também da rejeição por parte das autoridades judaicas de Jabne daqueles que tinham acreditado em Jesus. Porém, João não cessa de dialogar com a Sinagoga ${ }^{512}$. Ele quer convencer aos judeus, seus ouvintes/leitores, que Jesus veio realizar a esperança de Israel. O reenvio constante às Escrituras e à tradição oral é uma maneira de continuar este diálogo, apesar de muitos pontos terem sido fechados pelos judeus de Jabne. O cumprimento da Revelação em Jesus Cristo não suprime o papel que Israel conserva de portador da Revelação. A Torá de Moisés é cumprida pela Torá viva que é Jesus Cristo ${ }^{513}$ (v. 46c). Portanto, Jesus dirige-se a certos grupos fariseus ou cristãos-fariseus, em particular ${ }^{514}$.

\subsection{2. A relação autor/leitor}

A relação do autor com seu ouvinte/leitor caracteriza-se por uma persistência na sua comunicação. De acordo com as circunstâncias, seu trabalho de persuasão quer atingir os seus ouvintes/leitores, para a receptividade da nova concepção que ele se sente impelido a expor e que visa enfatizar a fé em Jesus como "o Filho enviado pelo Pai, para dar vida e fazer o julgamento" (vv. 21c; 22b; 27a-27b), sem comprometer a fé no Deus único.

$\mathrm{O}$ autor tem certeza de dois fatos: a divindade de Jesus e a unicidade de Deus - o que é difícil de conciliar ${ }^{515}$, sem comprometer o princípio de um único Deus. Admitir a divindade de Jesus é pôr em questão o monoteísmo herdado do judaísmo. Pretendendo, pois, agir para modificar a situação, oferece elementos que visem restabelecer a verdade de sua comunicação. Para alcançar esse intento,

\footnotetext{
é a vossa vida, e é por esta palavra que prolongareis vossos dias sobre o solo do qual ides tomar posse".

${ }_{511}$ Cf. ASHTON, J., Comprendere Il Quarto Vangelo, p. 220.

${ }^{512} \mathrm{O}$ mesmo acontecia em grande parte com os discípulos de Jesus. A ruptura de cristãos e fariseus, nos anos 80-90, é um dos dramas religiosos mais incompreensíveis e misteriosos do desígnio de Deus (cf. Rm 9-11). Cf. COLLIN, M.; LENHART, P., op. cit., pp. 12-13.

${ }^{513}$ Cf. Ibid., p. 89.

${ }^{514}$ MAIER, J., Entre os dois Testamentos, p. 215.

${ }^{515}$ Todo o Evangelho é um jogo permanente de perguntas dos homens $(6,42 ; 7,27 ; 8,14 ; 9,29$; 19,9) e a resposta de Jesus: venho de Deus... Meu Pai é quem me enviou..., etc.
} 
o autor adota a onisciência como seu ponto de vista psicológico ${ }^{516}$ e decide dar a palavra ao próprio Jesus. Jesus, o falante, ao dirigir-se a seus interlocutores por atos proposicionais e ilocucionários ligados ao tipo de expressão "amém, amém, eu vos digo" (v. 19c) quer distinguir a realidade singular a que se refere de outras realidades.

O primeiro ato que o autor requer do seu ouvinte/leitor é a sua atenção para a novidade da comunicação que está sendo revelada por Jesus. Faz isso chamando a atenção para a implicação da força ilocuciónaria de sua linguagem ao ativar neles os diversos níveis de implícito de sua fala, como por exemplo: - quem é esse que mesmo ameaçado e perseguido, fala com tal autoridade e não em atitude de desculpa ou súplica? Quem teria tamanha ousadia de dizer-se "Filho de Deus"? Será conveniente ouvi-lo para saber até onde ele poderá sustentar a veracidade de sua declaração? Quem pode assemelhar-se a Deus (cf. Is 40,25)?

Consciente que terá de responder a questões que problematizam as próprias validades pressupostas e que exigem apresentação de razões, que só podem ser fornecidas por uma ação comunicativa, o autor mostra-se em total disponibilidade para alcançar um nível de compreensão que favoreça essa possibilidade. A grande incidência de enunciações por meio de frases negativas ${ }^{517}$ é indicativa de que o autor tem a intenção de fazer uma lítotes ao introduzir afirmações cristológicas que ele pretende que sejam acolhidas por seus leitores como verdadeiras. Esse procedimento denota a força persuasiva dos atos linguísticos ilocutórios emitidos em sua função conotativa ${ }^{518}$. Essa caracterização do aspecto ilocutório dos atos linguísticos em seus diversos graus mostra a dificuldade na qual o autor se encontrava para fazer-se compreendido e aceito (vv. 38b; 40a-40b; 43a-43d). Daí que as proposições portadoras da novidade cristã venham afirmadas por meio da negação em contrário, a fim de que o respeito à condição teológica do leitor seja preservado, tornando-se mais fácil conduzi-lo a uma abertura e aceitação daquilo que está sendo comunicado.

\footnotetext{
${ }^{516} \mathrm{Na}$ crítica literária, isso não significa que o autor/narrador seja literalmente onisciente, como Deus, mas que ele adota uma postura ou posição que lhe permita acesso a informações e imagens relativas ao que os personagens pensam, sentem, pretendem, acreditam e assim por diante. Ele está presente como um observador oculto que escreve em retrospectiva.

${ }^{517}$ Cf. vv. 19d; 23c; 23d; 24f; 28a; 30a; 30d, 31b; 34a; 37c; 37d; 38a; 38c; 40a; 41; 42b; 43b; 44c; 45a; 47a. Este aspecto foi detectado na análise dos elementos sintáticos do discurso. Cf. 4.2.2.

${ }^{518}$ Cf. vv. 19d-19e; 22a-22b; 23c-23d; 24f-24g; 28a-28b; 30a; 30d-30e; 37c-37d; 38a-38b-38c; 40a-40b; 42a-42b; 43a-43b; 47a-47b.
} 
O segundo tipo de ato requerido ao ouvinte/leitor diz respeito a uma atitude de abertura na fé, à escuta da "Palavra" do Filho, o enviado do Pai: Quem escuta minha Palavra... e crê (vv. 24b-c-d-e-f-g), os que a ouvirem... (v. 25e). A ação esperada pelo autor, após apresentar uma série de testemunhos (vv. 31-39) é que o leitor creia. A meta, em relação à recepção de sua comunicação, pelas reações de ânimo que o texto apresenta, parece difícil de ser atingida: "não tendes sua palavra permanecendo em vós" (38a); "vós não credes..." (38c); "não tendes em vós..." (42b); "não me acolheis..." (43b); "vós o acolheríeis..." (43d); “como podereis crer..." (44a); "recebeis glória..." (44b); "e não procurais..." (44c). A frase condicional "se vós crêsseis..." (46a) mostra a evidência de que os judeus crentes estavam tentados a abandonar a fé, exatamente como os discípulos em 6,66. A insistência sobre o possessivo "minha palavra" nos versículos v. 24b e 47b (cf. também 8,31) permite identificar que a tentação de retornar à palavra dos Pais não era irreal ${ }^{519}$.

Porém, a resistência e a regularidade com as quais o autor persiste, mostra que ele tem pleno domínio da situação comunicativa: "vós enviastes..." (33a); “para que sejais salvos...” (34c); "vós quisestes..." (35c); “não quereis...” (40a); “não penseis..." (v. 45a) "se crêsseis em Moisés..." (v. 46a). O acentuado uso da segunda pessoa do plural para os interlocutores e a destacada referência a Moisés (vv. 45c; 46a) são indícios de que há um conflito de autoridades ${ }^{520}$.

Esses atos de fala contextualizados mostram a capacidade do autor de distinguir entre as possibilidades de modificar o contexto e a de permanecer incompreendido. Estrategicamente, de modo sutil, faz uma exigência a seus leitores a investigar as Escrituras, não apenas na esteira da interpretação tradicional, mas a descobrirem seu verdadeiro e originário sentido. $\mathrm{O}$ autor deseja que seus leitores, tanto o leitor implícito quanto os leitores reais, venham a crer que "homem Jesus" $(5,12)$, que curou o enfermo por sua "palavra" $(5,8)$, é o Filho de Deus. O pronome "vós" se dirige, portanto, a todos os receptores de sua mensagem.

\footnotetext{
${ }^{519}$ Cf. MANNS, F., L'Évangile de Jean à la Lumière du Judaïsme, p. 181.

${ }^{520}$ SEYNAEVE, J., Attitudes to Judaism in the Fourth Gospel, In JONGE, M., L'Évangile de Jean sources, rédaction, théologie, Belgique: Leuven, University Press, p. 352.
} 


\section{2. \\ O tema do discurso de Jo 5,19-47: "A Palavra de Jesus testemunha a unidade do Filho com o Pai".}

As análises linguísticas efetuadas nos aspectos formais do texto, neste trabalho (capítulo quarto), foram unânimes em constatar a coesão e a coerência textual do discurso de Jo 5,19-47, portanto sua unidade literária. Igualmente, o capítulo quinto, ao tratar dos motivos que fundamentam a argumentação do discurso, sublinhou a existência de uma unidade temática subjacente a todo o texto. Nele um fio condutor, um pensamento de fundo une toda a comunicação na relação Pai-Filho, com especial destaque à "unidade de ação" existente entre eles, expressa desde a enunciação que inicia o discurso: "O Filho, por si mesmo, nada pode fazer, senão só aquilo que vê o Pai fazer" (vv. 19d-e). Todos os motivos contêm elementos doutrinais que substanciam, de forma solene e categórica, esta afirmação da identidade de Jesus, como "o Filho" que age em consonância com o Pai que o enviou ao mundo (vv. 23e; 24d; 25d; 30e; 36f; 37a; 38b; 43a), para que ele concluísse "suas obras"(vv. 36b-c).

Demonstrando essa unidade de ação do Pai com o Filho, o autor procura fazer por meio de termos que evocam a criação ${ }^{521}$ - manifestação, por excelência, do poder divino para o povo de Israel - "Deus concluiu no sétimo dia a obra que fizera" (Gn 2,2). O fazer do Pai na criação - o qual realiza sua "obra" por meio de sua "Palavra" -, caracteriza a "Palavra" como reveladora do poder de Deus. Deus age falando. Esta Palavra da criação se define por sua eficácia: é uma Palavraacontecimento (cf. Gn 1,1-26). É a este trabalho do Pai (evgazonai) que se refere Jesus quando justifica seu agir, como "uno e constante" com o do Pai, na declaração que favoreceu o contexto para este discurso: $\Theta$ pathr nou ekv arti evgazetai kagw. evgazonai $(5,17) \AA$

Do ponto de vista do autor, as ações de Jesus são uma expressão do poder criador de Deus que continua a operar - suas obras - porém num outro nível; elas não se autoexplicam, mas servem antes como sinais que aquele que sabe discernir corretamente pode identificar como manifestações da glória divina ${ }^{522}$. São elas

\footnotetext{
${ }^{521} \mathrm{O}$ verbo poi eNé o termo pelo qual o Gênesis interpreta a atividade criadora de Deus. No texto a recorrência à forma verbal poien tem função retórica para exprimir a operatividade do Filho. Conferir nota 353.

${ }_{522}$ FREINE, S., Deus como experiência e mistério: a compreensão cristã primitiva In Concilium 289, 2001/1, p. 87.
} 
que vão ser sinais da potência que levará o homem a glorificar a Jesus como se glorifica o Pai (v. 23), ou a rechaçá-lo e, em consequência, rejeitar a vida (vv. $40 \mathrm{a}-\mathrm{b})^{523}$. A união nas obras manifesta a mais completa união das pessoas, preservando, desse modo, a unicidade de Deus. No Filho enviado, o Pai trabalha "até agora" (Elj arti), realizando sua grande obra de amor pelo mundo (5,17; cf. 3,16). Nesse capítulo 5 o que "Jesus faz" não recebe o nome de "sen® a" (sinais) mas de "बrga" (obras) ${ }^{524}$. Obras e Palavras no Evangelho de João exprimem a mesma realidade: equivalem ao agir do Pai. As palavras que Jesus fala não são propriamente suas, mas daquele que o enviou ao mundo (v. 24b-c; cf. 7,16; 14,24); as obras que Jesus realiza são as que o Pai o encarregou de concluir (vv. 36c-d). Está claro que "palavras e obras" são a mesma coisa, porque se fala de umas e das outras a partir da mesma ótica: a da origem, a da realidade mais profunda. Vistas a partir do Pai que enviou Jesus, palavras e obras são a tarefa que Jesus recebeu e que deve realizar. E neste sentido palavras e obras são primordialmente uma revelação de quem enviou Jesus, porque são suas palavras e suas obras ${ }^{525}$. Estas obras exclusivamente divinas, o Pai concede ao Filho realizálas: "Levantar os mortos - fazê-los viver -, e exercer o julgamento" (vv. 21b-c; 22b; v. 27c; 30a).

O cerne da questão que o discurso se dispõe a responder é o da identidade de Jesus, o Filho de Deus. E o contexto do texto é o da tensão suscitada pelo paradoxo do Evangelho de João ${ }^{526}$, que consiste em apresentar a realidade divina de Jesus como a glória do Filho encarnado, e sublinhar, ao mesmo tempo, sua humanidade $^{527}$. A tensão entre a transcendência de Deus e a imanência do ser

\footnotetext{
${ }^{523}$ O fato da rejeição histórica de Jesus é incontestável. O que o Evangelho procura é apresentar a rejeição em profundidade, quer dizer, esclarecer por que Jesus foi rechaçado. Neste texto tem-se um ponto de apoio para refletir sobre a incredulidade do tempo do leitor, que é a que mais interessa. Cf. TUÑI VANCELS, O. J., O Testemunho do Evangelho de João, Petrópolis: Vozes, 1989, p. 151.

${ }^{524}$ O Evangelho de João fala quase sempre dos sinais que Jesus "faz" (2,11. 23; 3,2; 4,54; 6,14. 30; 7,$31 ; 11,47 ; 12,18.37 ; 20,30$ ), mas quando fala da vontade de Deus que Jesus "faz", das obras do Pai que Jesus "faz", o termo usado é ergon

${ }^{525}$ Cf. TUÑI VANCELS, O. J., op. cit., p. 59.

${ }^{526}$ Se por um lado o texto narrativo (vv. 1-18), que oferece o contexto para o discurso, enfatiza "Quem foi o homem que disse...?" (5,12), por outro lado, apresenta a pessoa de Jesus com um conhecimento que ultrapassa os limites de sua condição humana, como onisciente: "Sabendo que estava assim há muito tempo..." $(5,6)$ e no v. 14 Jesus faz uma recomendação para o curado não pecar mais, além da declaração de Jesus que é uma afirmação de sua realidade divina: "Meu Pai trabalha até agora, e eu também trabalho" (v. 5,17). E o Evangelho repetirá diversas vezes: "Um homem que se chama Jesus" (9,11), "esse homem não vem..." (9,16); "eis aí um homem" $(19,5)$.

${ }^{527}$ BROWN, R., El Evangelio según Juan, p. 203.
} 
humano Jesus está na base de todo conflito, de toda incompreensão. O autor sabe que a chave de interpretação desse mistério é a "encarnação". Os temas anunciados no Prólogo encontram, aqui, sua fundamentação teológica e funcional.

A contundente afirmação do Prólogo, em forma de confissão de fé comunitária dos crentes joaninos, em 1,14, a qual afirma que a "Palavra se fez carne" assumindo a identidade de Jesus $(1,17)$, contém a substância da reflexão joanina dedicada ao mistério do Filho. E com o versículo 1,18 o evangelista tenta esclarecer a relação entre o I ogg preexistente $(1,1 \mathrm{a})$ que estava junto de Deus $(1,1 b)$ e era Deus $(1,1 \mathrm{c})$ com o aparecimento do Filho único, que estava no seio do Pai $(1,18)$, entre os homens. A tensão entre a transcendência de Deus e a imanência do ser humano desaparece no texto do Prólogo pela encarnação da Palavra de Deus: o`l ogoj sarx egeneto $(1,14)^{528}$. Assumindo a condição humana, tomou a decisão mais assombrosa (v. 14): revelando-se, atingiu o ápice da história da salvação ${ }^{529}$.

Consequentemente, a escolha da palavra Iogoj para designar o Cristo preexistente prende-se à idéia de "Revelação pela Palavra", comprovação da presença e da ação do Deus vivo desvendando seu próprio mistério ${ }^{530}$. Esta Palavra tem justamente por caráter essencial possuir uma existência pessoal ${ }^{531}$. Pela ação de fazer-se carne, o I ogoj se revela como Filho Único (v. 1,14. 18) ${ }^{532} \mathrm{e}$ revela o Pai $(1,18)$. A novidade cristã é que essa Palavra preexistente $(1,1)$ tenha para sempre assumido "a carne". ODI ogoj se encarnou para manifestar o que já existia. O I ogoj que estava em comunhão com o Pai $(1,1 b)$ faz comunhão com os homens (1,14-16). É por isso que o discurso pede a fé (v. 24c). Ver a Jesus já é

${ }^{528}$ GUILLET, J., Jesus Cristo no Evangelho de João, São Paulo: Paulinas, 1985, p. 14.

${ }^{529}$ Somente a encarnação do Filho de Deus realizou, em sua plenitude, a inserção de Deus na história humana. Sar xafirma a plena humanidade. BARRET, C. K., El Evangelio Según San Juan, Madrid: Cristiandad, 2003, p. 249.

${ }^{530}$ Por conseguinte deve-se procurar a pré-história do título de I ogoj no campo do judaísmo

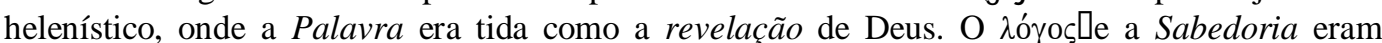
manifestações de Deus, pelas quais ele intervinha no mundo, instrumentos de sua ação. A Palavra de Deus comunicava a maior das sabedorias e é por isso que a lei dada por Moisés superava todas as sabedorias humanas (cf. Dt 4,5-8). O livro de Baruc celebrava a Sabedoria, cujos caminhos eram inacessíveis aos homens, mas que Deus dera a Israel sob a figura da lei (cf. Br 4,1-2). GUILLET, J., op. cit,. p. 14.

${ }^{531}$ Ibid., p. 14.

${ }^{532}$ A realidade pessoal de Jesus Cristo faz que sejam superadas as instâncias mediadoras. Agora há um Mediador, o $\lambda$ oyos de Deus que se fez carne. Ele é a própria Sabedoria, a própria Palavra de Deus, portanto, seu verdadeiro intérprete. Cf. Ibid., p. 28. 
ver o I ogoj "a vida que estava junto do Pai e que nos apareceu" (Jo 1,1; Jo 14,9 s; 12,45 ; cf. 1 Jo 1,1-3).

O poder de Deus na criação, revelação e salvação através de sua "palavra" foi personificado pelo evangelista ao se referir ao Verbo, Jesus Cristo, a revelação definitiva de Deus $(1,14-18)$. Aplicando-o a Jesus é numa perspectiva totalmente nova que ele vai condensar a história do mundo, de Israel e da vinda do Filho ${ }^{533}$. Essa é uma revelação histórica (v. 30a) que, aos poucos, vai desvendando o seu sentido, e pede testemunhos (vv. 31b-c; 32d; 33b; 34a; 36a-e; 37b; 39d). Portanto, a não ser na fé (v. 24c), o desejo do homem de ver a Deus tal qual ele é não pode ser satisfeito por completo. Por isso a visão da glória de Deus em Jesus está condicionada à fé (vv. 40a-b) ${ }^{534}$. Produziu-se assim uma grande mudança na revelação de Deus ao assumir uma existência na carne de Jesus e, consequentemente, no sentido de glória $^{535}$. A glória é ver Deus na carne $(1,14$; $2,11)^{536}$. E isto é difícil de ser acolhido.

O acontecimento do envio do Filho comporta um duplo aspecto: O Filho enviado assumindo a carne humana foi crucificado e por sua morte foi nela glorificado, transformando radicalmente a situação dos homens, de todos os tempos; quer dos vivos (vv. 25-26), quer dos mortos (v. 27-29). O processo da construção da identidade do Filho de Deus está intrinsecamente conectado à sua morte. A identidade de Jesus surgiu do processo de interação com seus seguidores e da interpretação das Escrituras ${ }^{537}$. E a "autoridade" para essa interpretação das Escrituras está sendo disputada.

\footnotetext{
${ }^{533}$ JAUBERT, A., Leitura do Evangelho segundo João, São Paulo: Paulinas, 1982, p. 28.

${ }^{534}$ No Evangelho de João a fé é uma forma de visão: "Não te disse que, se creres, verás a glória de Deus?" (12,40; cf. 6,40;).

${ }^{535} \mathrm{O}$ povo de Israel aprendeu o Temor de Deus ao associar a santidade do Transcendente à sua condição humana frágil e pecadora. Daí que a glória de Deus se tornou motivo de temor e era reservada a pessoas escolhidas. Não era medo psicológico, mas reverência perante Deus, que se revela. Em Jo a glória não mais amedronta ninguém, ela é causa do crer dos discípulos (cf. 2,11) e é para ser contemplada (cf. 17,24). JAUBERT, A., op. cit., p. 32.

${ }^{536}$ No texto do Êxodo 33,18-23 há limites para a visão de Deus. No texto joanino do NT o I ogoj feito carne permite que todos possam contemplá-lo. Deus se faz ver na pessoa de Jesus. Este é o único modo do ser humano ver a face de Deus. A face de Jesus é a face de Deus (cf. 14, 9). E assim, em Jesus, está superada a impossibilidade do homem de ver a Deus (cf. Jo 14,9 ss). No NT Deus se faz visível na pessoa de seu Filho, Jesus Cristo. Se há uma visão que antecede a fé, a própria fé desemboca num conhecimento e numa visão (cf. Jo 1,51; 3,21. 36). Contudo, a transcendência de Deus não permite que Jesus revele toda a glória que lhe cabe (Jo 17,5), porque também ele pertence ao mundo invisível, das realidades que não se veem e, que são a fonte das que vemos (cf. Hb 11,1). Portanto, a não ser na fé o desejo do homem de ver a Deus tal qual ele é não pode ser satisfeito por completo. Somente "Jesus Cristo, o autor e realizador da fé" pode possibilitar ao homem a visão de Deus (cf. Hb 12,2).

${ }^{537}$ Cf. MEEKS, W., Cristo é a questão, São Paulo: Paulus, 2007, pp. 65-67.
} 
A tensão interativa da figura humana-divina de Jesus torna-se, então, o elemento estruturador do discurso. $\mathrm{O}$ autor sabe que a primeira resposta sobre Jesus-homem, o Filho, é identificá-lo com Jesus de Nazaré (v. 30a) que se dá a conhecer por suas obras (vv. 36d-e) que são as que o Pai lhe encarregou de executá-las. É ele quem realiza a vontade de Deus (vv. 30c-d), e é quem morre (vv. 25b-c; 12,23). Este é o testemunho da verdade que Jesus dá (v. 36a) ${ }^{538}$. O limite da experiência humana é o testemunho. Ele é o conteúdo das Escrituras. Foi sobre este que Moisés escreveu (v. 46c). O autor do texto queria não só que os ensinamentos de Jesus fossem acolhidos, mas também que lhes atribuíssem o caráter de "Escrituras", como mostra o fato de que suas obras continuam e imitam a ação do Pai, e o do lugar que o Filho enviado ocupa na história da salvação.

Nesse discurso Jesus é o homem da "Palavra"; somente ele fala, é a "Palavra" que traz vida eterna (v. 24c). Por conseguinte, a unidade temática do discurso de Jo 5,19-47 pode ser expressa no seguinte tema: “A Palavra de Jesus, o Filho, testemunha sua unidade com o Pai”.

\section{3. \\ Relação do discurso com o texto narrativo $(5,1-18)$}

\subsection{1.} O discurso e o texto narrativo

O contexto do texto discursivo $(5,19-47)$ está na dependência da narrativa que o antecede, porque ela oferece o espaço-temporal da troca dialógica, que é, em parte, o mesmo para os dois. O discurso tem por finalidade a fundamentação das pretensões de validade do dito de 5,17: "Meu Pai trabalha até agora, e eu também trabalho". O relato desta declaração exofórica de Jesus está longe de ser casual; ele constitui a base do discurso. A ênfase, portanto, está no "dito" e não no "evento" "539. É um contexto de informações e de crenças partilhadas, um contexto traduzido em termos de mundos possíveis.

O texto literário narrativo é particularmente inteligente, porque faz do versículo 17 um sumário antecipativo do argumento do discurso a seguir: uma

\footnotetext{
${ }^{538}$ TUÑI, VANCELS O. J., O Testemunho do Evangelho de João, p. 88.

${ }^{539} \mathrm{O}$ fato de as respostas de Jesus no Evangelho de João, muitas vezes parecer ter uma relação bem oblíqua com a ocasião que as ensejou deve-se à presença da ênfase no dito, e não no evento. Cf. GABEL, J. B.; WHEELER, C. B., A Bíblia como literatura, São Paulo: Loyola, 1993, p. 181.
} 
justificação completa e detalhada da pretensão de Jesus ${ }^{540}$. Assim, abre a possibilidade de se aprofundar, no texto discursivo, como essa realidade pode acontecer. O ouvinte/leitor do discurso pode concluir que a declaração de Jesus é uma afirmação de sua filiação divina, especialmente, se fizer uma remissão à obra realizada por Jesus, na cura do enfermo $(5,8)$ por meio de sua "palavra".

Essa cura $(5,8)$ é o primeiro sinal do Evangelho que não é numerado e nem chamado de sinal, e em que a iniciativa é de Jesus. O enfermo dá uma desculpa evasiva $(5,7)$, o doente não suplica nada a Jesus, não tem mediadores; Jesus dá uma ordem $(5,8)$ e a cura se realiza pela obediência à palavra $(5,9)$. A verificação da cura é feita destacando o dia de sábado $(5,9)$, porém a resposta de fé sobre o milagre está ausente. O homem que é curado vai denunciar Jesus aos judeus e isto traz sérias consequências (vv. 16. 18).

Por essas peculiaridades o autor mantém o leitor ligado o tempo todo em um só personagem: Jesus, que ao subir a Jerusalém, para uma festa dos judeus, se depara com uma multidão, que lota o pátio de uma piscina pública, no qual se encontram em condições extremas de vida humana vários tipos de doentes, entre eles alguns que há dezenas de anos vivem à espera de "um momento" que possa lhes trazer uma mudança de vida. Todo o desenvolver da primeira cena (v. 5,1-9a) converge para um desfecho no qual "Jesus" (v. 15), provoca por sua "palavra" uma mudança repentina na vida de um dos doentes que recebe dele a ordem de "se levantar e andar" $(5,8)$. A Palavra cheia de autoridade está no centro do relato e é obedecida pelo interlocutor.

O discurso faz a releitura do texto narrativo e convida o leitor a acompanhálo nesse percurso. Constata um imenso salto qualitativo no deslocamento das condições de vida dos doentes, que se inverte, quando o "homem" que ordenou ao doente, ao ser identificado, faz uma declaração que culminará com uma ameaça de morte. Essa inversão exige a participação do leitor para preencher os vazios do relato: a cidade de Jerusalém, o caos onde deveria haver a alegria da festa - a festa dos judeus - na qual, todos ao mesmo tempo: cegos, coxos e paralíticos viviam sua condição humana impossibilitada de mover-se. A condição é que ele viva em situações que lhe possibilitem pôr-se em pé. Desde a criação os homens foram

\footnotetext{
${ }^{540}$ Ele afirma que, como Filho de Deus, Jesus age como o próprio Deus: Assim como o Pai segue trabalhando, o Filho, também, trabalha $(5,17)$.
} 
feitos para ficar eretos, para andar. "Levanta e anda" $(5,8)$, eis a ordem da nova criação.

As referências ao sábado 5,9b-10. 16 e 18, sobretudo o v. 18, põem a questão da autoridade de Jesus, cuja origem constitui um dos argumentos para a justificativa do discurso: "E por esta causa os judeus perseguiram a Jesus, e procuravam matá-lo, porque fazia estas coisas no sábado”. Para os dirigentes judeus o sábado era meio de controle sobre o povo e prova da sua submissão; ao observá-lo, o povo reconhecia a autoridade divina que reclamava o ensino oficial $^{541}$. Porém, o que está em causa é a declaração de Jesus $(5,17)$ pela qual é acusado de ser blasfemador $(5,18)$, e não a cura em dia de sábado ${ }^{542}$.

Quando se escreveu o Evangelho segundo João, a exegese mais estendida ${ }^{543}$ do descanso sabático de Deus oferecia argumentos suficientes para apoiar a postura do evangelista da incessante atividade de Deus. Deus é essencial e imutavelmente o criador (evgazetai); e o que Deus faz, também faz Jesus (v. 19), de modo que também Jesus cria (ergazetai $)^{544}$. Porque o Pai trabalha no presente é justo que também o Filho o acompanhe nessa atividade, mesmo em dia de sábado (tBV). A questão é novamente abordada em João 7,23. Pela prática do Shabbat, Israel, ainda hoje, testemunha o Deus criador e colabora para a sua criação. Essa revelação é concebida em vista da redenção que o Shabbat prefigura e antecipa. Pelo Shabbat, vivido na intimidade de Deus, Israel conhece a Deus e o faz conhecer (cf. Ex 31,14). Realização inaugurada pelo Shabbat judaico e por seu cumprimento em Jesus Cristo. Portanto, o trabalho de Jesus no sábado é a demonstração de que a atividade do Filho é concomitante à ação criadora do Pai (vv. 19d-e).

\footnotetext{
${ }^{541}$ MATEOS, J.; BARRETO, J., O Evangelho de São João, São Paulo: Paulinas, 1989, p. 261. ${ }^{542}$ É significante que neste texto não apareça a palavra "Lei".

${ }^{543}$ Barret diz que esta exegese pode ser encontrada na literatura rabínica de Rab Gamaliel II, Rabi Joshua, Rabi Eleazar ben Azarias e Rabi Aquiba. Cf. ExR. 30,6; GenR. 11,10. A literatura rabínica é um vasto conjunto de compilações nas quais se encontra, a partir do século I, o essencial da Torá oral dos fariseus. Esta literatura compreende: a) As compilações organizadas, em Israel, pelos Tanain (mestres dos dois primeiros séculos); a Mishná e a Tosefta, que são paralelas. Os midraxes haláquicos que se interessam especialmente pela parte prática da Torá (halaká): assim sendo, não há compilação do Gênesis, mas duas baseadas no Êxodo: Mekilta de rabi Ismael e Mekilta de rabi Simeon ben Yohai, uma sobre o Levítico, uma sobre os Números: Sifré Bamidbar e outra sobre o Deuteronômio: Sifré Debarim. - B) As coleções organizadas pelos Amoraim (mestres de Israel e de Babilônia dos séculos III ao VI): em Israel, o Talmud dito de Jerusalém e os midraxes hagádicos antigos, em particular Gênesis Rabah, Lamentações Raba, Levítico Rabah e a Pesiqta de Rab Kahana. Em Babilônia o Talmud da Babilônia. Cf. COLLIN, M.; LENHART, P., Evangelho e tradição de Israel, p. 15.

${ }^{544}$ Cf. também BARRET, C. K., El Evangelio según san Juan, p. 386.
} 
Ao recolher dados do texto narrativo para construir o texto discursivo o autor deixa claro que não pretende somente narrar o acontecido, ele já entrevê aí a possibilidade de ampliar a visão do fato por meio do discurso, no qual as explicações das hostilidades de 5,16 e 18 são transformadas em temas doutrinais que convergem para a pessoa de Jesus, o Filho, que é quem lhes dá sentido e os ilumina $^{545}$ (vv. 19-23). Em todo o discurso se acentua a singularidade da relação de intimidade do Filho com o Pai expressa em 5,17: "meu Pai e eu".

Em 5,14 a advertência, no Templo, sobre as consequências resultantes do pecado, ao homem curado, pode fazer referência ao v. 25: se Jesus libertou-o de sua enfermidade foi para fazê-lo compreender que com maior razão ele poderia ser libertado do poder do pecado (vv. 25-27). O autor vislumbra o futuro da humanidade no "homem Jesus" $(5,15)$. A cura indica o poder do Filho de dar a vida eterna por sua palavra (v. 24). Aí começa outra história, a do Filho de Deus que faz a festa da "Nova criação", onde não há mais necessidade de se esperar por "alguém" que movimente a água, pois chegou "a hora e é agora" (vv. 25b-c) em que "do seio dos crentes" jorrarão rios de água viva, no último dia da festa, que é o mais solene (cf. 7,37ss). O alcance cristológico do sinal é posto à luz. Desse modo, 5,1-18, prepara e, além disso, fornece os fundamentos para a fé na Palavra de Jesus, o Filho, proclamada em 5,19-47. Na atividade da ação comunicativa do discurso escrito, o critério do contexto é uma das características do processo ${ }^{546}$.

\subsection{2. O discurso e as questões do texto narrativo}

A parte narrativa do capítulo quinto (5,1-18), como acontece, geralmente, com a estrutura do pensamento do evangelista no "Livro dos Sinais" (1,19$12,50)^{547}$, dá mais espaço aos elementos externos da experiência; a parte discursiva (5,19-47), mais didática, aprofunda o mistério visibilizado pela experiência. Portanto, não são textos independentes, mas se complementam.

\footnotetext{
${ }^{545}$ Cf. TUÑI VANCELS, O. J., O testemunho do Evangelho de João, p. 161.

546 Cf. GRILLI, M., artigo Pragmatica $e$ analisi del texto. Disponível em: http://www.evangeliumetcultura.org/IT/Pragmatica\%20e\%20analisi\%20del\%2Otesto.php Aces sado em 14 de maio de 2012.

${ }^{547} \mathrm{O}$ evangelista apresenta seu Evangelho, na seção do livro dos sinais, dentro de uma estrutura de pensamento que se expressa por perícopes narrativas e discursivas, ou seja, por "obras e Palavras".
} 
No texto narrativo os sinais para a interpretação de $5,1-47^{548}$ se fazem presentes por meio do comentário do evangelista, dado ao simbolismo da cena (5,1-5), pela palavra de Jesus $(5,6.8)$ que está contextualizada $(5,9-10)$ e também pelo conteúdo dos diálogos (10-18). A narração de cada cena é muito sucinta; apesar disso, o narrador dirige o leitor quando enquadrou o relato, dando indicações de tempo, de lugar, da ocasião e da situação na qual atuam os personagens que falam na história. Em um só versículo $(5,1)$ : Mđa. taứa h èrth. twh Voudai un kai . anedh Vhsouj eij terosol una, pode-se ver três marcas literárias que estão associadas: Mđa. taứa (a indicação de sequência usada pelo autor: cf. 2,$12 ; 3,22 ; 5,1.14 ; 6,1 ; 7,1)$; a referência a uma festa dos judeus: h₹ èrth. twh Voudai wn; e a mudança de lugar de Jesus que acontece quando sobe a Jerusalém ${ }^{549}$ : kai . anaegh Vhsoi' ejj ter osol unaÁÉ exatamente este versículo que tem atraído a atenção de estudiosos da obra joanina e do qual são extraídas as questões da identificação da festa e do deslocamento do capítulo.

\section{a) A identificação da festa}

As festas dos judeus eram o modo como eles sempre tinham celebrado a aproximação de IHWH. A celebração de uma festa hebraica é chamada zikkaron (!AkД) - substantivo derivado do verbo zakar ( $\mathrm{rk} \not$ ) que tem o sentido de recordar. Uma lembrança que recorda a presença ativa de Deus junto ao povo hebreu no passado, agora presente na celebração litúrgica da festa. $\mathrm{O}$ dia por excelência para essa recordação era o Shabbat ${ }^{550}$.

O texto salienta que a cura se deu no sábado $(5,9 b)$. Em alguns círculos judeus, o sábado presente prefigurava o sábado da era escatológica. O Shabbat é a maior de todas as festas, o início de todas as santas convocações" (cf. Lv 23,3) ${ }^{551}$. O Shabbat é, realmente, primícia do mundo por vir, desse "dia que será inteiramente Shabbat" ${ }^{352}$. Se o autor intenta uma ligação entre o sábado $(5,9)$ e o trabalho escatológico de Jesus (vv. 25-29) ele considera que "a realidade do Shabbat é o Cristo".

\footnotetext{
${ }^{548}$ Geralmente se reconhece em Jo 5,3b-4 uma glosa tardia porque essa passagem não figura nos $\mathrm{P}^{66}$, no $\mathrm{P}^{75}$ e no B.

${ }^{549}$ CULPEPPER, A. R., Anatomy of the Fourth Gospel: A Study in Literary Design, Filadelfia: Fortress Press, 1987, pp. 135-140.

${ }^{550}$ Cf. COLLIN, M.; LENHARDT, P., Evangelho e tradição de Israel, p. 89.

${ }^{551}$ Cf. Ibid., pp. 15-16.

${ }^{552}$ Cf. Ibid., p. 15.
} 
A importância que o Evangelho concede às festas (cf. 2,13. 23; 5,1; 6,4; 7,2; $10,22 ; 12,1 ; 13,1)$, mostra sua importância na divulgação dos ensinamentos de Jesus, porque é através das festas que ele entra em contato com os judeus de Jerusalém $^{553}$. Por outro lado, é preciso ter presente que as festas judias são o "locus theologicus" por excelência da teologia judaica ${ }^{554}$. Por isso o quadro da festa é também o quadro teológico que se presta para discutir e questionar a teologia judaica ${ }^{555}$.

O culto, que desde sempre fora considerado como um lugar teológico importante, exige agora ser repensado. Depois da destruição do Templo, no ano 70 (sec. I), a sobrevivência dos fariseus havia imposto uma deslocação, uma transferência do culto do Templo para a Sinagoga ${ }^{556}$. O judaísmo pós-guerra judaica era ainda um repensamento da própria celebração. A festa litúrgica do Templo e a piedade popular viviam em um estado de transição e de adaptação ${ }^{557}$.

O Evangelho ao falar das festas judaicas deixa entrever aspectos que apresentam uma tensão entre a comunidade joanina e a Sinagoga farisaica: "uma festa dos judeus". Os cristãos joaninos estão agora separados dos seus amigos daquele tempo e da vida que levavam na Sinagoga (cf. 9,22;12,42;16,2). Mas essas não eram as únicas causas da necessidade de repensar as celebrações deles da presença de Deus. Agora, neste momento, separados igualmente das celebrações tradicionais, mostra o esforço do Evangelho em criar uma experiência religiosa diversa e autônoma daquela judaica com ritos de admissão, em substituição do tempo da festa ${ }^{558}$. Era um momento propício para aprofundar

\footnotetext{
${ }^{553} \mathrm{E}$ mais concretamente, com os fariseus e os oficiais do templo que levaram a termo a perseguição, conseguindo a condenação de Jesus.

554 Dentro dessa perspectiva a "festa dos judeus" no v. 1 talvez já oriente para o evento da salvação, antes mesmo que se concentre no sábado escatológico. Cf. GRASSO, S., Il Vangelo di Giovanni, 2008, p. 234.

${ }^{555}$ Particularmente, as festas da Páscoa e das Tendas têm um lugar especialmente importante neste sentido. De um ponto de vista doutrinal talvez a festas das Tendas seja ainda mais importante que a da Páscoa. De fato, a festa dos Tabernáculos era a festa messiânica por excelência, era a festa mais carregada de sentido escatológico, a festa judia da esperança. A páscoa podia ser o centro, mas as Tendas era o lugar doutrinal mais profundo. As discussões dos cap. 7-8-9 estão no contexto das festas das Tendas; de fato a festa da dedicação era chamada também de a festa das Tendas do inverno. No fundo, do ponto de vista teológico, no Quarto Evangelho, há uma forte concentração das discussões de Jesus com os judeus no contexto da festa das Tendas. Será conveniente ver seu sentido. Cf. TUÑI VANCELS, O. J., O testemunho do Evangelho de João, p. 48 et seq.

${ }_{556}^{556}$ Cf. Ibid., p. 175.

${ }^{557}$ BARREIRA TREBOLE, J., "Antiguo" e "Nuevo" Testamento. Las identidades judía y cristiana: líneas de continuidad y de divergencia In Rivista Biblica, anno LX, ABI, 2012, EDB, p. 161-188. (p. 184).

${ }^{558}$ Cf. GRASSO, S., Il Vangelo di Giovanni, p. 234, nota 5.
} 
questões fundamentais que afetavam a identidade de judeus e cristãos como as que são relativas ao discurso.

Relacionando-se à pesquisa pode-se concluir a favor da hipótese que não identifica nenhuma das festas do calendário litúrgico. A menção de "uma festa dos judeus" nesse caso tornar-se-ia pouco mais que um marcador histórico para explicar a presença de Jesus em Jerusalém $(5,1)$. Se a solenidade não está indicada, seria porque para o leitor o importante não é saber qual o motivo que fez Jesus ir a Jerusalém, mas que a ação, realizada por Jesus em seguida, deve ser interpretada dentro de um contexto festivo. $\mathrm{O}$ autor não estaria fazendo referência a uma festa anual, ligada ao calendário litúrgico do Templo, mas ao sábado, ocasião que favorecia a Jesus afirmar sua autoridade divina, como enviado de Deus, para apresentar sua interpretação das Escrituras, um dos motivos do discurso, em torno da qual havia muitas discussões ${ }^{559}$. "Esse dia era um sábado" (v. 5,9). É memorial da criação e também da obra de salvação agora revelada: Aquele "sábado" que era o grande dia! $(19,31)^{560}$.

\section{b) A questão do deslocamento do capítulo 5}

Conforme demonstrado na pesquisa realizada (capítulo II), o capítulo 5,1-47 foi considerado deslocado do contexto do Evangelho, isto é, fora da ordem pretendida pelo autor do Evangelho ${ }^{561}$. Porém, para provar tal deslocamento, as hipóteses, em sua maioria, constataram-se insuficientes. No entanto, deve-se considerar também a posição dos exegetas que não concordaram com esse

\footnotetext{
${ }^{559}$ Cf. KEENER, C., The Gospel of John, p. 635.

${ }^{560}$ Esta hipótese foi defendida por Brown, Mlakuzhyil e Keener, conforme pesquisa. Cf. BROWN, R., El Evangelio según Juan, p. 414; KEENER, C., op. cit., p. 635; Cf. MLAKUZHYIL, G., The Christocentric Literary Structure of the Fourth Gospel, 1987, p. 103.

${ }^{561}$ Conforme a pesquisa do capítulo II as hipóteses mais defendidas: a) A hipótese literária mais explícita se baseia nas indicações topográficas que iniciam os capítulos 4; 5; 6; em 4,6 Jesus havia deixado a Judeia, dirigindo-se para Galileia; e já em 5,1 ele está novamente em Jerusalém. Logo a seguir em 6,1 está de volta à Galileia. b) Outras duas hipóteses se fundamentam em indicações cronológicas: uma baseada na omissão $(5,1)$ da indicação do nome da "festa dos judeus". (Esta ausência se justificaria se ao capítulo 5 seguissem imediatamente os capítulos 7-8-9ss). E a outra na sucessão das festas do calendário do Templo. Este argumento deriva da hipótese de que o evangelista contextualizou as ações de Jesus em Jerusalém a partir do calendário das festas judaicas (cf. 2,13. 23; 7,2. 14; 10,22; 12,1. 12). c) Há ainda outra hipótese que supõe que o capítulo 6 não fazia parte do evangelho original, mas teria sido acrescentado posteriormente, de modo que a sequência ficou distorcida. A inserção do capítulo 6 entre os capítulos 5 e 7 - e não a transposição do capítulo 5 - teria originado o problema. Assim também pensam exegetas mais modernos. d) por fim a que é fundamentada em critérios literários e nas tensões temáticas do próprio texto provocadas, inclusive, pela suposição de que o autor, de idade avançada, teria morrido antes da conclusão de sua obra.
} 
deslocamento, e que atribuíram a ordem atual do Evangelho ao próprio autor ${ }^{562}$. A diversidade de hipóteses atribuídas a esse possível deslocamento do capítulo 5 é um indício de que a análise de sua estrutura literária estaria na dependência da análise do texto em sua situação comunicativa, uma vez que a intencionalidade do autor é o critério prioritário para definir a organização textual: segundo Barret, "quem publicou o Evangelho sabia o que fazia" 563.

Se o texto narrativo põe em destaque literário o deslocamento de Jesus subindo para Jerusalém $(5,1)$, entre uma recém-vinda da Judeia $(4,3)$ e logo em seguida uma passagem pelo Mar da Galileia (6,1s), e novamente voltando para a Judeia $(7,10)$, tem-se que concordar que a topografia do Evangelho de João assume uma carga teológica que é difícil de se negar ${ }^{564}$. A ela estariam associadas as festas do calendário religioso do Templo. Nesse Evangelho as questões relacionadas às afirmações cristológicas que geram discussões são concentradas em Jerusalém, por ocasião das festas judaicas ${ }^{565}$. O fato de aludir às festas é para dar razão ao tom de oposição radical que Jesus encontrou e que com toda a certeza o levou à morte.

A cidade de Jerusalém servia de cenário para abordar, ou mesmo aprofundar, determinados temas doutrinários que tinham repercussão entre os que se achavam com autoridade para reconhecê-los legítimos ou contestá-los, e entre os peregrinos que vinham a essa cidade para as festas. Entre estes temas se incluíam aqueles que questionavam a identidade da fé cristã, especialmente quando esta começou a tomar caminhos próprios ${ }^{566}$. A separação de caminhos entre os judeus e os cristãos vem marcada, sobretudo, por pontos fixados estrategicamente, em forma de polarização, do início ao fim do Evangelho. A ruptura com o Templo, significada pela expulsão dos mercadores $(2,13)$ e a crença na morte e ressurreição de Jesus (18,1-20-31), constituem os dois pontos de distância, apresentados pelo evangelista, no início $(2,13 \mathrm{ss})$ e no fim do Evangelho $(18,1-20,31)$.

\footnotetext{
${ }^{562}$ Conferir pesquisa (2.1).

563 BARRET, C. K., El Evangelio según san Juan, p. 55.

${ }^{564}$ Cf. MANNS, F., L'Évangile de Jean à la Lumière du Judaïsme, p. 182.

${ }^{565}$ Em 2,13-3,36 e 5,1-47 estava em Jerusalém e a partir do capítulo 7 o seu ministério público $(1,19-12,50)$ foi na Judeia, especialmente, na cidade de Jerusalém $(2,13 ; 3,11-21$. 31-36; 5,1-47; 7,16-19. 21-24. 28-29. 33-36. 37b-38. 8,12. 14-19. 21. 23-24. 25b-26).

566 BARREIRA TREBOLE, J., "Antiguo" e "Nuevo" Testamento. Las identidades judía y cristiana: líneas de continuidad y de divergência In Rivista Biblica, 2012, EDB, pp. 161-188.
} 
Para o ministério de Jesus fora de Jerusalém, o Evangelho reserva temas sobre a abertura e o acolhimento para a fé, quer dos discípulos (1,19-51; 2,1-12;), quer de outros que desejem acolher (4,29. 39-42. 45 e 4,46-54), ou para questões de continuidade com a tradição judaica que entrem em contradição com as experiências cristológicas intracomunitárias $(6,60)$, como as do discurso na Sinagoga de Cafarnaum (6,26-71). Pois, para o autor, no aprofundamento da reflexão cristológica desenvolvida na comunidade, é essencial não perder de vista sua matriz judaica ${ }^{567}$.

O que caracteriza os discursos joaninos contextualizados em Jerusalém é, antes, a disposição de rejeitar a revelação ${ }^{568}$, cujo conteúdo se concentra em temas doutrinais de importância para o judaísmo, especialmente os que apresentam questões de descontinuidade relativas à interpretação das Escrituras e à que põe em questão a base do monoteísmo com um culto ao "Lógos-arché-Sabedoria" preexistente encarnado em Jesus $(1,1)$, o Cristo-Palavra $(1,14)^{569}$, que proclama a mais absoluta novidade do Novo Testamento. Esse texto do Prólogo não está situado geograficamente, mas o aprofundamento de suas afirmações que constituem a substância do "corpo do Evangelho" está contextualizado sempre em Jerusalém $^{570}$. Por conseguinte, o destaque dado à subida de Jesus para Jerusalém $(5,1)$, está relacionado com a temática do discurso dos versículos 19-47 e não com a racionalidade geográfica do Evangelho ${ }^{571}$, significando, com isso, que a posição do capítulo 5 no Evangelho não está na dependência do motivo topográfico ${ }^{572}$.

\section{4.}

\section{Relação do capítulo 5 com o contexto próximo do Evangelho}

O capítulo 5 se encontra inserido entre a narrativa do encontro de Jesus com a Samaritana, a da cura do filho do funcionário real $(4,46-54)$, ao qual the é concedido, pela Palavra de Jesus, o "dom da vida" e a da multiplicação dos pães (6,1-15), da qual decorre um longo discurso sobre o dom da vida eterna dada pelo

\footnotetext{
${ }^{567}$ As raízes judaicas dos títulos cristológicos: o Enviado, o Filho do homem, o Messias, o Pão do céu, etc Cf. MANNS, F., op. cit., pp. 193 e 195.

${ }_{568}$ Cf. TUÑI VANCELS, O. J., O testemunho do Evangelho de João, pp. 148-151.

${ }^{569}$ BARREIRA TREBOLE, J., op. cit., p. 161-188.

${ }^{570}$ KEENER, C. S., The Gospel of John, p. 113.

${ }^{571}$ Cf. CARSON, A. D., O comentário de João, p. 101.

${ }^{572}$ Esta teoria foi defendida por renomados exegetas como Barret, Kümmel, Brown e Carson (cf. item 2.1).
} 
"pão vivo descido do céu" (6,26-71). Em ambos os capítulos a revelação de Jesus vai se desenvolvendo por palavras e por sinais $(4,50 ; 6,48)$. Como no capítulo 5 , a narrativa do milagre, no caso da "multiplicação dos pães" (6,1-15), precede ao discurso. Em ambos a iniciativa e a palavra de Jesus conservam o lugar central na narrativa, oferecendo, assim, a base para o que vai ser dito.

O Capítulo 5, em suas duas partes - narrativa e discursiva - é rico em simbolismos joaninos, que apontam para a direção de vários temas que estão desenvolvidos nos dois capítulos que lhe são limítrofes (4 e 6): o tema da água $(4,7 \text {. 10. 11. 13. 14-15) })^{573}$, da travessia do mar $(6,1 \cdot 16-21)$, da hora $(4,21$; vem a hora e é agora 4,23), da vontade daquele que me enviou (v. 4,34a; 6,38. 40 40); obras de Deus $(4,34 b ; 6,28-29$. 30) do conhecimento de Deus $(4,22)$, crer na palavra $(4,41.47 .53)$, do testemunho (v. 4,39. 44), do julgamento $(4,35.36)$, da ressurreição $(6,39.40)$, da vida eterna $(4,14$. 36; 6,27), o Pai-Filho $(6,27.40 .46)$, meu Pai (6,32), ver o Pai (6,46a.b ) Filho do Homem (6,27. 53. 62), o Pai que me enviou $(6,38.45 .44)$ etc.

O capítulo 4 serve de aporte cristológico ao capítulo 5. O texto se situa no nível da revelação da história da salvação que culmina com a confissão de fé provocada pela escuta da palavra - na pessoa de Jesus como "Salvador do mundo" $(4,42)$. Jesus, o Messias revelador, é o ponto de chegada da esperança de Israel e o ponto de partida dos tempos escatológicos (4,21-26). Ele, que conhece o Pai, inaugura o culto dos últimos tempos, em "espírito e verdade" $(4,23)^{574}$ e diz da impossibilidade de vê-lo "face a face" porque "Deus é espírito" (4,24). Prepara assim para a aceitação da face humana de Deus, no seu Filho, no capítulo 5. O evangelista traz a afirmação da identificação do próprio Jesus como "Messias" à samaritana, no capítulo 4: "Sou eu que falo contigo" $(4,26)^{575}$, e no capítulo 5 , como "o Filho", também feita pelo próprio Jesus: "Meu Pai e eu = o Pai e o Filho" $(5,17$. 19), reunindo, assim, nos dois referidos capítulos, os elementos essenciais de seu projeto teológico, que é provocar o leitor a confessar a fé em Jesus, como “o Messias, o Filho de Deus” (20,31).

\footnotetext{
${ }^{573}$ A unidade dos capítulos 2-4 prepara o cap. 5 pelo papel variado da água nestas seções. Em Caná a água da purificação (2,1-12), e Nicodemos tem que nascer da água e do Espírito (3,5. 8); o batismo com água administrado por João Batista é objeto de discussão $(3,22-23.25$; 4,2) Jesus oferece água viva à Samaritana $(4,10-15)$ e em 5,1-18 mostra que o poder de cura não vem da água, mas de Jesus. Somente por sua palavra o homem enfermo há 38 anos é curado.

${ }_{574}$ Cf. MANNS, F., L'Évangile de Jean à la Lumière du Judaïsme, p. 180.

${ }^{575} \mathrm{O}$ texto do capítulo 5,1-47 não menciona o termo Messias.
} 
A confissão de fé de 4,46-50, após uma estusiasta recepção pelos galileus (4,43-45), põe em relevo a eficácia da "Palavra" pronunciada por Jesus "Vai, teu filho vive!". Essa narrativa tem por finalidade destacar a ação da palavra de Jesus e a reação de aceitação incondicional dos que a testemunharam, servindo de condução para o leitor ficar atento ao que vai ser revelado depois disso (5,1: Mđa. tauta).

No capítulo 4 a "Palavra do Messias" $(4,26)$ inaugurou uma nova era nos relacionamentos com os samaritanos e pagãos; neta. tauła, no capítulo 5, a "Palavra do Filho", dirigindo-se aos judeus, quer prosseguir a revelação do mistério de sua pessoa, como enviado do Pai, na condição de Filho. Novamente, no início do capítulo 6, a ligação com o tema antecedente acontece por meio da mesma marca literária nđa. tauka. Pode-se ver nesse procedimento um indício de que o autor queira sublinhar não a continuidade literária, mas temática.

A revelação da Palavra que vem sendo apresentada continua no capítulo 6 com o seu poder vivificador, através do discurso do "Pão da vida" que se inicia pela exortação a trabalhar nas obras de Deus $(6,28)$, a qual consiste em acreditar naquele que ele enviou $(6,29)$, o pão que desce do céu e dá vida ao mundo $(6,33)$. Esse discurso de Jesus em Cafarnaum com a profissão de fé dos Doze representa o ponto alto da manifestação de Jesus e a adesão mais firme de seus discípulos na Galileia: "Senhor, a quem iremos? Só tu tens palavra de vida eterna" (v. 68). A referência contínua à fé que vivifica (vv. 35. 40. 47) faz com que se interprete o alimento do "Pão da vida" (vv. 34. 41. 48) precisamente com o dar a vida aos que creem nele $(5,24 ; 6,35.40 .47)$, incluindo os versículos que fazem referência à ressurreição do último dia (vv. 40. 44).

Admite-se, no capítulo 6, um substrato sapiencial ao apresentar Jesus como o "Pão da vida". A identificação do pão com a Palavra de Deus como alimento está associada ao maná (cf. Dt 8,3) e, consequentemente ao êxodo, cuja "palavra que sai da boca de Deus" sacia o homem e mata a sede, mas é do domínio da linguagem sapiencial (cf. Sir 24,19-22; Is 49,10; 55,1s; Sb 16,20) ${ }^{576}$. Aqui a identificação da palavra-alimento transcende a teologia sapiencial quando faz referência à "Palavra que se fez carne" $(1,14)$ : "O Pão que eu darei é a minha carne para a vida do mundo" (v. 51; cf. também vv. 53-58). A narração situa o

${ }^{576}$ CABA, J., Cristo, Pan de Vida, Madrid: BAC, 1993, p. 207. 
episódio na proximidade da Páscoa $(6,4)$, que comemorava justamente a libertação efetuada por Moisés no Egito. O leitor está ciente de a que Páscoa o autor está se referindo: à Páscoa da morte de Jesus, na qual se realizou a libertação da humanidade, com a consumação da obra que o Pai o encarregou de realizar (v. 36b-c). A oposição entre o pão Maná, dado por Moisés (6,32), e o pão que dá a vida, dado por Jesus $(6,33)$, é indicadora do contexto de tensão existente nas discussões da Sinagoga sobre a interpretação das Escrituras. Jesus afirma em Jerusalém que a vida é encontrada nele $(5,40 \mathrm{~b})$ e que Moisés havia escrito sobre ele (Jo 5,46).

Por conseguinte, tanto o capítulo anterior (Jo 4), quanto o posterior (Jo 6) são partes integrantes da revelação da "Palavra de Deus que se fez carne" no homem Jesus, já proclamada no Prólogo. Assim sendo, a posição do capítulo 5 está no centro dessa seção, portanto, em seu devido contexto.

\section{5 . Relação do tema com o contexto do Livro dos Sinais}

O tema da revelação de Deus por meio da Palavra do Filho, conforme foi amplamente constatado no percurso deste trabalho, é central neste discurso. O Evangelho de João é o único que apresenta a revelação histórica da salvação em Jesus como a Palavra pré-existente que estava em Deus $(1,1)$ e se fez carne em Jesus Cristo, como Filho único $(1,14$. 18) - em forma de confissão comunitária e respaldada por testemunho $(1,15)$. À atuação missionária dessa Palavra no mundo, o evangelista dedica toda a parte do Evangelho chamada de "Livro dos Sinais",577. No discurso de 5,19-47 está explicitamente revelado, no homem Jesus, o mistério do agir dessa "Palavra do Filho", portadora da vida, como "obra de Deus" (vv. 24. 32. 36).

Criando um ambiente para iniciar a exposição do que foi proclamado no Prólogo, por meio do testemunho de João Batista ${ }^{578}$, testemunho esse acolhido por alguns de seus discípulos (1,35-51), o evangelista faz o anúncio de que os que

\footnotetext{
${ }^{577}$ Excetuando o Prólogo, o conteúdo da primeira parte do Evangelho $(1,19-12,50)$ é chamado, desde Bultmann, de "o Livro dos Sinais" e a segunda parte de "Livro da Glória".

${ }^{578}$ A primeira apresentação histórica pública de Jesus acontece por meio do testemunho de João Batista, após a constatação de sua identidade e como sendo apenas "uma voz" $(1,23)$ e não o Messias $(1,20)$. Declarando-se como não sendo digno de "desatar-lhe as correias da sandália" $(1,27)$, João Batista abre espaço para que se inicie o processo da construção da identidade de Jesus como mestre $(1,38)$ e o "Messias" esperado $(1,41)$.
} 
acolheram o testemunho "verão coisas maiores" $(1,50)$. E inicia essa "mostra" com a abundância do vinho no banquete messsiânico (cf. Am 9,13; Is 25,6-9;) das Bodas de Caná, no qual manifestou a sua glória. A relação do vinho com a palavra pertencia ao campo semântico da Palavra de Deus (cf. Jr 23,9; Pr 9,5) e a mudança da água em vinho no NT era a revelação da nova Lei trazida por Jesus (cf. 1,17 a graça e a Lei), que muda a regra do vinho (2,9; 19,26; cf. Mc 2,22; 14,24). Imediatamente antes da perícope das Bodas de Caná Jesus diz aos discípulos que eles "verão coisas maiores" $(1,50)$ e isso faz referência literal à unidade de ação entre o Filho e o Pai, quando diz no discurso que o "Pai the mostrará obras maiores" (v. 20d //1,50) e à "glória" (v. 44c//2,11) que nessa ocasião foi manifestada. O texto remete à Aliança do Sinai, quando Moisés comunica ao Senhor, no Monte, a resposta dos israelitas a sua Palavra: "Tudo o que YHWH disser nós o faremos" (Ex 19,6), que em 2,5 está posta na boca da mãe de Jesus: "Fazei tudo o que ele disser". Nesse mesmo capítulo 2, quando da cena da expulsão dos vendedores do Templo, ele apresenta Jesus agindo declaradamente como Filho que fala com autoridade: "Não façam da casa de meu Pai uma casa de comércio" $(2,16)$.

O capítulo 3 põe o acento na "Palavra" de Jesus como mestre que vem da parte de Deus $(3,2)$, cujo ouvinte e interlocutor é Nicodemos, fariseu e mestre em Israel. Esse capítulo apresenta dois pequenos textos discursivos (3,16-21 e 31-36), que muito se relacionam com o Discurso de 5,19-47. No primeiro, iniciado com a expressão “Amém, amém, digo-vos", se destaca a qualidade dessa fala: Jesus não fala como os mestres de Israel, fala como Filho, o enviado de Deus. A relação Filho único - Deus $(3,16)$; Deus - Filho $(3,17)$ é, aqui, ampliada pelos motivos decorrentes dessa relação, quais sejam: o motivo do envio do Filho único, por "Deus", para salvar o mundo; a necessidade de crer nele, porque esse crer assegura ao crente a vida eterna; o do julgamento, e das obras. No segundo (vv. 31-36), a relação Pai - Filho substitui Deus - Filho, com ênfase na intimidade dessa relação: "o Pai ama o Filho e tudo entregou em suas mãos"; além disso, trata dos temas do testemunho e do enviado que fala as palavras de Deus, concluindo com a repetição do v. 18 do primeiro texto em forma de inclusão: "Quem crer no Filho tem a vida eterna e quem se recusa crer no Filho não verá a vida" (3,36 a-b). Todos esses temas tratados nesses dois discursos do capítulo 3 
são colocados pela primeira vez no Evangelho e serão retomados no discurso de 5,19-47, onde são expostos com mais argumentação e profundidade teológica ${ }^{579}$.

A relação com o capítulo 7 é mais pontual. Alguns exegetas consideraram o trecho de 7,15-24 como continuação do capítulo 5 (cf. item 2.3). O contexto da festa das Tendas $(7,2$ s) e a menção às obras realizadas no sábado $(7,23)$, serviram de argumentos para tal compreensão ${ }^{580}$. Mas aqui (7,23-23) o motivo da perseguição e a justificativa de Jesus agir no sábado são diferentes; e o foco teológico central desse capítulo é a identidade de Jesus como Messias (7,25-27. 31. 40-42), não mostrando a relação Pai - Filho.

Já o capítulo 8 (exceto 8,1-11) tem estreita relação temática com o discurso estudado. Os temas da relação Pai - Filho, do testemunho, do julgamento, do Filho do Homem, do enviado, das obras, da glória, da verdade e da "palavra" se repetem em todo o capítulo, como para confirmar na prática o que fora anunciado em 5,19-47. A ênfase na minha palavra (vv. 31. 37. 43. 51. 52), em guardar a palavra (vv. 37. 47. 55), e os termos conhecer, ensinar e verdadeiro são indícios de que o contexto é de discussão entre os intérpretes das Escrituras. O egw, ė min proclamado de forma absoluta por Jesus, apenas nesse capítulo (vv. 24. 28. 58), é característico dos textos de revelação que expressam a identidade divina de quem fala. Os interlocutores de Jesus nesse diálogo são identificados com os fariseus (v. 13) e com os judeus (vv. 22. 31. 48. 52. 57). A forma dialógica manifesta o contexto polêmico no qual se travaram os debates sobre a aceitação da identidade de Jesus.

Com o capítulo 9, o capítulo 5 tem semelhanças consideráveis na narrativa da cura, mas não traz nenhuma referência à relação Pai - Filho, e nele a questão da identidade de Jesus como Messias $(9,22)$ é central. Alguns motivos do discurso $(5,19-47)$ aparecem sutilmente quando fazem referência ao enviado $(9,7)$, ao Filho do Homem $(9,35)$ e a Moisés $(9,28)$. É evidente que os episódios dos capítulos 5 e 9 devem ser interpretados a partir de um único contexto histórico semelhante. Em ambos se reflete a relação do cristianismo primitivo com o mundo circundante em primeiro lugar, do mundo judeu, carregado de hostilidade em relação às pretensões de Jesus ${ }^{581}$; em segundo lugar, esta perícope põe de manifesto, de

\footnotetext{
${ }^{579}$ A relação com os capítulos 4 e 6 foi apresentada no item 6.4.

${ }^{580}$ Este assunto já foi bastante elucidado no capítulo segundo deste trabalho.

${ }^{581}$ BARRET, C. K., El Evangelio según san Juan, pp. 377-378.
} 
maneira muito peculiar, os métodos dos adversários, que dirigem seus ataques contra indivíduos ainda não pertencentes à comunidade cristã, mas que haviam entrado em contato com ela e experimentado o poder das forças milagrosas que atuavam em seu seio. Interrogando a estes homens, os adversários tratavam de obter provas para combater a fé cristã. O sentido da cegueira $(9,41)$ é figura da obcecação da mente ou da resistência à mensagem ${ }^{582}$.

O mesmo contexto de rejeição está presente no capítulo 10, inclusive com a mesma acusação de blasfêmia de 5,18 (cf. 10,31. 33. 39). Esse capítulo 10 apresenta muita afinidade teológica com o discurso de 5,19-47. Especialmente na relação Pai - Filho (vv. 17-18. 25-30), porém aqui a ênfase é dada na unidade de pessoa existente entre eles: "Eu e o Pai somos um" (10,30); "O Pai está em mim e eu no Pai" (10,38). A declaração expressa em 10,10 sintetiza toda a missão do Filho dada pelo Pai: "Eu vim para que todos tenham vida e a tenham em plenitude". Também o poder de Jesus de dar e de retomar a vida está bem salientado em 10,17-18: "Por isso o Pai me ama, porque dou minha vida para retomá-la. Ninguém a tira de mim, mas eu a dou livremente. Tenho o poder de entregá-la e poder de retomá-la”. Nesse capítulo, os versículos 32-38 parecem ser um desenvolvimento da temática do testemunho, apresentada no discurso de 5,1947, no qual se evoca o testemunho das obras, das Escrituras e do Pai (vv. 31-39). Enquanto que no discurso $(5,19-47)$ a temática está a serviço somente da identidade de Jesus como o Filho, não aparecendo a questão do Messias, aqui a identidade de Jesus como Messias $(10,24)$ é também apresentada.

Com o capítulo 11 a relação acontece no nível da experiência que a comunidade faz do poder da Palavra de Jesus de dar vida aos sepultados que "ouvirão a voz do Filho do Homem e sairão" (5,28cd-29a). Aqui Jesus se autoapresenta como "a ressurreição e a vida" $(11,25)$, que remete ao discurso de 5,19-47 quando afirma que este poder o Filho recebeu do Pai (v. 21). Chama atenção a confissão de fé de Marta, quando proclama sua fé em Jesus como Messias, o Filho de Deus (11,27), unindo, ao mesmo tempo, os dois temas que serão fundidos no objetivo que o evangelista quer alcançar de todo leitor (20,31). O fim do ministério público de Jesus se encerra com sua entrada em Jerusalém, para a festa da Páscoa, onde pronuncia o último discurso-diálogo dirigido aos

${ }^{582}$ Cf. TUÑI VANCELS, O. J., O testemunho do Evangelho de João, p. 161. 
ouvintes não discípulos $(11,23-28.31-32.35 .36 .44-50)$. Aqui temas como o da hora que é chegada $(11,23 / / 5,25 b-c)$, da honra $(11,26 / / 5,23)$, do Filho do Homem $(11,23$. 34a-b) e da vida eterna $(11,25 / / 5,24 c)$ remetem ao discurso de 5,19-47.

A questão do reconhecimento da identidade de Jesus como "Filho de Deus" já está presente nos capítulos 2 e 3; portanto, não se pode atribuir ao capítulo 5 o início da polêmica de Jesus com os judeus, como é comum acontecer. Desde o início do Evangelho (Jo 2) o autor entra deliberadamente na problemática do monoteísmo judaico coexistente com a confissão de fé em Jesus como "Filho de Deus" ${ }^{, 583}$. E a identificação como Messias vem desde 1,41, sendo reafirmado pelo próprio Jesus em 4,26. Portanto, a causa das polêmicas é a afirmação da identidade de Jesus, como "Messias, o Filho de Deus", que percorre todo o Evangelho. Esses são temas judeus que entram em contraposição com Jesus ${ }^{584}$. Aliás, sobre a polêmica pode-se retroceder ao Prólogo: "Veio para o que era seu e os seus não o receberam" $(1,11)$.

O quadro no qual o evangelista desenvolve sua ideia é o da fé judaica em Deus que se revela como Pai, cuja vontade de amar dá origem a toda criação e do qual provém um plano de salvação para a humanidade $(3,16)$, agora revelado e realizado por meio de Jesus-Messias, seu Filho. A Cristologia Joanina está orientada essencialmente à soteriologia. Tudo o que diz e faz o Jesus joanino, tudo o que revela e opera por "obras e sinais", tem lugar com vistas ao alcance da salvação dos homens, à aquisição da "vida divina" ${ }^{585}$. É essa atribuição da filiação divina ao homem Jesus que é evidenciada no Livro dos Sinais ${ }^{586}$, de modo que esses episódios proporcionavam ao evangelista um ponto de partida externo, porquanto serviam para ilustrar o dilema do mundo o qual enfrenta a revelação, com sua hostilidade ${ }^{587}$.

\footnotetext{
${ }^{583}$ Todos esses textos estão situados em Jerusalém.

${ }^{584}$ Cf. TUÑI VANCELS, O. J., op. cit., p. 176.

${ }^{585}$ Cf. GILBERT, M.; ALETTI, J-N., A Sabedoria e Jesus Cristo, 1985, pp. 89-98.

${ }^{586}$ Cf. MUÑOZ LÉON, D., Evangelho de João In LEVORATTI, A.J. (Dir.)., Comentário Bíblico Latino Americano, Nuevo Testamento, 2007, p. 620 et seq.

${ }^{587}$ BARRET, C. K., El Evangelio según san Juan, pp. 377-378.
} 


\section{6.}

\section{A função do discurso no contexto global do Evangelho}

O autor do Evangelho de João, ao concluir sua obra (20,31), quis deixar claro sua finalidade: "Estes (sinais) foram escritos para que continueis a acreditar que Jesus é o Cristo, o Filho de Deus, e para que, crendo, tenhais vida em seu nome" ${ }^{588} \AA$ E com esse objetivo de confirmar ou provocar a fé nos leitores/ouvintes estruturou seu Evangelho, a partir de uma seleção de material da tradição recebida $(20,30)$, que foi estrategicamente organizado e narrado, de modo a revelar, progressivamente, Jesus como o Messias, Filho de Deus. É à luz desse objetivo que será avaliada a função do discurso de Jo 5,19-47.

\section{a) A que se propõe o texto?}

A dinâmica literária impressa pelo evangelista a todo o evangelho dá ao leitor o ponto de vista a partir do qual ele deve ser lido. Não se pode procurar pelo sentido do texto, sem falar, ao mesmo tempo de seu objetivo. E isso é confirmado pela finalidade de seu escrito $(20,30)$. A localização do texto 5,19-47 constitui-se um elemento fundamental nessa dinâmica. O texto tem grande ressonância nas duas grandes partes do Evangelho: no "Livro dos Sinais" e no "Livro da Glória".

A revelação que Jesus apresenta sobre o Pai e que o Pai apresenta sobre o seu Filho no discurso de 5,19-47 tem a função de substanciar teologicamente a dimensão reveladora da filiação divina que perpassa todo o Evangelho ${ }^{589}$, no qual a identidade de Jesus é repetidamente demonstrada e confirmada, e cujo tom é dado pelos sinais e pelos discursos devidamente selecionados pelo evangelista. É o único texto discursivo do Evangelho que apresenta de modo compacto, em forma de sumário, a doutrina da filiação divina em suas duas formas: desde a intimidade do Filho em Deus $(5,19-23 / / 1,1 ; 1,18)$ até a concretude de sua existência histórica $(5,30 / / 1,14)$.

588 Os manuscritos trazem, neste versículo 31, duas formas de grafia do verbo pisten. pi stahte (no presente do subjuntivo) e pi steushte (no aoristo subjuntivo): tauka de gegraptai i ha pisteilsĐite ofi Vhsou' etin o' cristoj o' uiòj tou qeoul kai. i ha pi steuphtej zwhn echte en tW/ ononati autoul A tradução no presente seria no sentido de confirmar, manter a fé, dirigindose assim aos que tinham abraçado a fé e estavam em crise: "para que continueis a acreditar". No aoristo subjuntivo o sentido seria de proclamar a fé para iniciantes: "para que creiais". Essa tradução optou pelo verbo no presente do subjuntivo, não só porque a oração introduzida por i hạ (para que) no Evangelho de João está sempre no tempo presente, mas também, por coerência com o que vem sendo apresentado neste trabalho.

${ }^{589}$ CARREIRA DAS NEVES, J., Escritos de são João, Lisboa: UCE, 2004, p. 80. 
O discurso (vv. 19-47) apresenta a unidade do Pai e do Filho a partir da unidade na obra da criação (v. 36) e da obra da salvação (vv. 21-22). Retoma o Prólogo, que apresenta o "Logos" como agente divino pelo qual Deus tudo criou $(1,3)$, e o capítulo 3, que anuncia o envio do Filho, como emissário do Pai, com a missão de realizar a obra de salvação do mundo $(3,16 \mathrm{~s})$. O capítulo 5 , assim, demonstra minuciosamente como esses atos divinos são cumpridos pelo Filho, oferecendo-lhes o devido amparo teológico, uma vez que esses dois textos $(1,3$; 3,16) não aprofundam essas afirmações. Assumindo a figura do enviado, esse capítulo desenvolve uma teologia da filiação divina com todas as prerrogativas de Deus, o Pai.

Os poderes divinos de dar vida a quem quer $(5,21 \mathrm{c})$ com o poder de ressuscitar os mortos $(5,21$ e 5,25-26; 28-29) e de exercer o julgamento divino $(5,22)$, até então, conhecidos como atos exclusivos de Deus são agora revelados pelo discurso, como atribuições do Filho concedidas pelo Pai. Nas constantes referências à atuação de Jesus - que age como o próprio Deus - está implícita a pretensão do autor de que o texto se propõe a revelar a história da salvação pela Palavra encarnada $(1,14)$, com todas suas potencialidades, existentes desde o princípio $(1,1)$, mas que até então continuava velada e agora manifestada na pessoa de Jesus, o Filho. Portanto, a chave para ler o Evangelho de João é o Prólogo.

O Prólogo não só introduz Jesus como o Logos divino, mas também dá as pistas para a grande questão que vai permear o Evangelho: a da recepção da identidade de Jesus. Os versículos 11-12 do Prólogo são um sumário do que vai ser apresentado no Evangelho: "Veio para os que eram seus e os seus não o receberam". É no cerne da teologia joanina, que põe a acentuação sobre a encarnação do Logos e sua rejeição da parte dos seus $(1,11)$, que se coloca a necessidade de abordar a problemática da recepção da proclamação da fé da comunidade joanina no "Logos que se fez carne!" $(1,14)$. O discurso de 5,19-47 é um texto muito próximo ao Prólogo, mas com função diferente. Responde a uma elaboração no estilo discursivo, da confissão de fé expressa no material poético (1-18), em função de perguntas e problemas da comunidade e de seu entorno. 
No livro dos Sinais a posição privilegiada que o discurso $(5,19-47)$ ocupa após a declaração de Jesus à Samaritana de que ele é o Messias $(4,26)^{590}$ - que vem anunciar tudo (aragged $\dot{e} /$ hình apanta) - com termos que pertencem ao

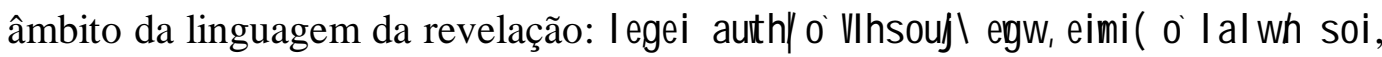
é um indicador de sua importância. Tanto o tema de "Jesus Messias" quanto o de "Filho de Deus" recebem um tratamento conceitual nestes dois capítulos (4 e 5). Daí em diante a questão da fé no Messias e Filho do Homem (7, 7,26. 27. 31; 9,35) vai unificando-se à fé no Filho (caps. $8 ; 10 ; 11 ; 12$ ), até tornar-se uma só realidade na confissão de fé de Marta: "Eu creio que és o Messias, o Filho de Deus, aquele que devia vir ao mundo" $(11,27)$. A fé messiânica é a fé no enviado de Deus, seu Filho: O Messias é o Filho.

A concentração na relação Pai - Filho, demonstrada durante a análise dos motivos, induz a considerar, em primeiro plano, a importância da função do texto de Jo 5,19-47, também no livro da Glória ou Paixão (13-20), no desenvolvimento da cristologia da encarnação, especialmente pelo acento no motivo da chegada da "hora" (cf. 5,25) que abre essa seção: Antes da festa da Páscoa, sabendo Jesus que tinha chegado a "hora" de passar deste mundo ao Pai, tendo amado os que eram seus, amou-os até o fim $(13,1 ; 3,13)$. A teologia do envio responde a uma necessidade da fé cristã, não só para fundamentar a identidade de Jesus como "aquele" que desceu do céu, mas também para fundamentar sua morte - como "aquele" que vai voltar para onde estava antes da encarnação - quando chegar a "hora": "sabendo que tinha saído de Deus e a Deus voltava" (cf. 16,28) ${ }^{591}$.

A volta ao Pai torna-se o centro dos discursos que pertencem à seção dos capítulos 13-17 e que precedem à narrativa da paixão, que em João adquire o sentido de "glorificação" (cf. 13,31-32; 3,14). Esses discursos caracterizam-se por apresentar a pessoa de Jesus como onisciente e, ao mesmo tempo, já ressuscitado e ainda no mundo $(13,33 ; 14,3$. 25. 29). A relação de intimidade e de confiança existente entre o Pai e o Filho do discurso de 5,19-47 é, sobremaneira, acentuada nestes capítulos, com especial destaque para o envio do Espírito Santo "Paráclito", que é declaradamente obra conjunta dos dois, do Pai e do Filho (cf. 14,26; 15,26;

\footnotetext{
${ }^{590}$ No capítulo 4,25 a mulher samaritana diz: oi ed ofi Messiaj ercetai o' l egonenoj cristoj। ofan el ahl eke hoj ( aragged è/hǹnh apantaÂ

${ }^{591}$ A teologia do envio foi muito útil até mesmo para justificar a absurda história de um Messias crucificado com a qual o povo judeu estava espantado. Cf. CARSON, A. D., $O$ comentário de João, p. 107.
} 
16,15). O reforço da ação conjunta do Pai e do Filho enviando o Paráclito à comunidade - trazida por estes capítulos - preparava a narrativa da Paixão e fortificava a afirmação da identidade do Filho de modo mais eclesial, pela vivência da Paz trazida pelo Espírito, que agora se tornava o novo Enviado $(20,19)$ e os ajudaria no processo de conhecimento da verdade sobre Cristo, Filho de Deus $(16,13)$.

Também o capítulo 16 retoma o motivo da perseguição $(5,18)$ como sendo uma advertência de Jesus aos discípulos da ameaça à missão do Evangelho, que era clara e poderia desencadear temor ou mesmo desistências. A realidade não é algo à parte do conhecimento. A presente situação da igreja vivida pela comunidade marca o irreconciliável antagonismo entre e igreja e a sinagoga, realidade da qual o evangelista foi contemporâneo. Os pontos discutidos não são aspectos acidentais ou periféricos: as convicções judias mais centrais é que são questionadas. Portanto, o discurso se propõe a agrupar os elementos essenciais da doutrina da filiação divina, a fim de oferecer aos discípulos e missionários fundamentos teológicos para a elucidação dos pontos controversos e para a evangelização.

\section{b) Que contribuições esse discurso traz à finalidade explícita do evangelista?}

O Evangelho destaca os pontos nevrálgicos nos quais há ruptura ou continuidade. Os textos em que há afirmações relacionadas à identidade de Jesus como Filho são mais marcados por dissensões ou controvérsias do que os que afirmam sua identidade messiânica. Para o evangelista uma não pode ser confessada sem se aceitar a outra. Este discurso é um momento particularmente dedicado às explanações teológicas sobre a filiação divina de Jesus que iluminará a sua identidade messiânica.

Da perspectiva do evangelista houve um notável desenvolvimento do entendimento quanto à compreensão dos discípulos sobre quem Jesus era, especialmente após a ressurreição e exaltação de seu Senhor. Mas se tratava do desenvolvimento do entendimento, não de uma nova invenção teológica $(16,13)$. Compreende-se, pois, o esforço do autor, para que se reconheça a declaração de 5,17 como verdadeira revelação da identidade de Jesus. Em 5,18 são mencionados dois motivos teológicos que certamente se consolidavam em meio a questões disputadas por contemporâneos do tempo em que o Evangelho foi escrito: "dizia 
ser Deus seu próprio Pai, fazendo-se, assim, igual a Deus”. A gravidade desta afirmação só pode ser compreendida à luz do tempo do evangelista (cf. cap. 16), caracterizado pela hostilidade teologicamente condicionada entre o seu grupo de judeus-cristãos e a maioria judaica circundante, que se opunha a aceitar a filiação divina de Jesus ${ }^{592}$.

A questão fundamental que dominava os cristãos do fim do século I era a da identidade do "Verbo que se fez carne" $(1,14)$. Para o Evangelho de João, a encarnação é a ideia matriz ${ }^{593}$. A verdade da encarnação foi muito difícil de ser aceita $^{594}$. A história da aceitação da divindade de Jesus implica mudanças, traz descontinuidade $^{595}$. A novidade cristã frente ao judaísmo produziu graves tensões que se expressam nas discussões de Jesus com os judeus e que podem ser concentradas numa pergunta fundamental: que fica do judaísmo depois de Jesus? $\mathrm{Ou}$, formulando de outra maneira: que representa a vinda de Jesus frente às pretensões judaicas? ${ }^{596}$

A função do discurso é demarcar a fronteira da fé cristã que se caracteriza pela profissão de fé em Jesus como o Filho de Deus que foi enviado ao mundo, rompendo, assim, também, a fronteira da fé judaica. $\mathrm{O}$ discurso se impõe pela autoridade da própria comunicação. Não há nenhum outro texto no Quarto Evangelho que apresente, em uma só concentração literária, nem com tal profundidade teológica, a cristologia da filiação divina de Jesus. Especialmente no texto de Jo 5,19-47, o mistério de Jesus remete a uma única e inusitada relação entre o Pai e o Filho, que se baseia em um "ver e ouvir" (vv. 19c e 30b), em "ser enviado e realizar sua vontade" (vv. 23e; $24 \mathrm{~d} ; 30 \mathrm{e})^{597}$, que destaca claramente a

\footnotetext{
${ }^{592}$ Cf. WENGST, K.. Il Vangelo di Giovanni, Brescia: Queriniana, 2005, p. 211.

${ }^{593}$ Cf. Ibid., p. 214.

${ }^{594}$ Em primeiro lugar porque ela só poderia acontecer em Israel onde a revelação de Deus se fazia por sua Palavra; em segundo lugar, porque, paradoxalmente, em Israel, a fé no Deus único e transcendente não permitia tal realidade. A sua Palavra é a Torá.

${ }^{595}$ Os discípulos de Jesus anunciaram que o Templo (já destruído) como lugar da presença de Deus era o corpo de Jesus (Jo 2,21), as leis de pureza - ritos de purificações (2,1-12); a ruptura do repouso sabático (Jo 5,9), etc.

${ }_{596}^{596}$ Cf. Ibid., p. 215.

${ }^{597}$ A derivação do mistério de Jesus remonta a uma visão e a uma voz celestial (Mc 1,11; 9,7). A identificação que se faz de Jesus mediante a visão e a voz tem significado fundamental para Jesus. Sua oração, sua obediência, seu dom de fazer as obras e, também seu modo peculiar de ser diante dos seguidores e dos opositores se baseiam nesse acontecimento originário, que o converte no 'eleito' e no 'amado', no 'servo de Deus' e no 'Filho de Deus'. A combinação do Espírito e da voz é de índole jurídica (dos testemunhos); as palavras recordam o S1 2,7 e também Is 42,1. O Evangelho de João converte esse acontecimento originário em um testemunho dado pelo Batista, análogo à compreensão do testemunho messiânico: ele é assumido no processo do "ver" e do "ouvir" que tem por objeto a Jesus de Nazaré (Jo 1,32s). A acentuação da unidade de Deus e do
} 
superioridade das verdades cristãs. $\mathrm{O}$ discurso de 5,19-47 com sua afirmação da unidade de ação do Pai e do Filho, testemunhada por sua Palavra de vida eterna (v. 24), é de máxima importância para toda a teologia do Evangelho, não só por constituir-se numa unidade temática bem determinada, que oferece o substrato teológico que sustentará o desenvolvimento progressivo da doutrina da teologia da encarnação, mas também porque é o texto que, em larga escala, oferece ao leitor a chave da compreensão do mistério da filiação divina para sua confissão de fé em Jesus como "Messias e Filho de Deus" (20,31).

único mediador entre Deus e os homens, o homem Cristo (Messias) Jesus, mostra traços judeus cristãos herdados da tradição do Antigo Testamento (cf. Ex 4,16) que foram complementadas e ampliadas. Cf. MICHEL, O., verbete pathr In BALZ, H.; SCHNEIDER, G., DENT, p. 828 et seq. 


\section{Considerações conclusivas}

O discurso de Jo 5,19-47 é, entre os estudiosos do IV Evangelho, um dos mais difíceis de chegar a um consenso temático. A pesquisa bibliográfica (cap. II) demonstra que as três questões do capítulo 5 mais discutidas levantadas, seja a do próprio discurso, seja no contexto anterior (como a da identificação da festa e do deslocamento do capítulo 5) foram consideradas, como casos pontuais. A consideração do discurso de Jo 5,19-47 em chave literário-discursiva, no entanto, mostrou haver entre elas uma interrelação, na qual o discurso era o elemento catalisador porque jogava luz sobre as outras duas. A importância dessa constatação reside no fato de que se tornou evidente a exigência de se compreender este texto em sua totalidade e em sua função no capítulo 5, já que um texto não é um agrupamento temático, mas uma comunicação, com vistas a uma finalidade. Abordar assim o texto foi preponderante para certas conclusões.

Tratar o discurso pela via de sua dinâmica comunicativa exigiu a pergunta pela intenção pragmática do texto. Nessa ótica, compreender o texto de Jo 5,19-47 significou compreender a estratégia literária que o autor utilizou em seu discurso para atingir sua finalidade. No capítulo III, foi apresentado o percurso metodológico da análise pragmalinguística, que deveria dar sustentação teórica ao estudo do texto na abordagem comunicativa. A análise exegético-teológica realizada, neste estudo, no texto discursivo (vv. 19-47), sob o prisma da pragmalinguística, veio confirmar essa necessidade de se investigar o texto bíblico a partir do texto em si, isto é, como um discurso, já que um enunciado nunca está completamente isolado; ele sempre faz parte, de maneira efetiva e observável, ou de maneira potencial e conjeturável, de um texto maior.

O itinerário para esse procedimento foi pautado em três etapas. A primeira etapa, no capítulo IV, se ocupou do conhecimento dos aspectos formais do texto de 5,19-47, os quais incluíram os aspectos sintáticos, a linguagem, o vocabulário, a coesão e, por fim, as coerências textual e pragmática. Na abordagem comunicativa, grande importância teve a coerência pragmática. Ela manifestou 
não só o procedimento estratégico do autor, mas especialmente a situação da qual ele se serviu para construir seu leitor ideal, por meio dos atos linguísticos locutórios, ilocutórios e perlocutórios. Este momento foi indispensável para contribuir a uma nova leitura do texto em estudo, uma vez que a metodologia adotada reorientou os olhares do leitor na direção dos interlocutores, deixando claro que toda obra não só prevê, mas também, constrói o seu leitor ideal, que é aquele no qual a intenção do texto alcança sua realização. Daí em diante ficou evidente que a abordagem comunicativa parte da interação entre o locutor e o alocutário, uma vez que a finalidade do ato ilocutório é fazer com que o alocutário faça algo. O leitor real cuidadoso, conforme ficou demonstrado nessa etapa, pôde encontrar as pistas liberalmente espalhadas.

A abordagem do sentido do texto por meio da análise dos motivos (cap. V) permitiu perceber no discurso seis categorias de motivos apresentadas, em sequência, no texto e depois analisadas em ordem hierárquica; em cada um deles, a centralidade do evento comunicativo da revelação da identidade de Jesus, a Palavra que se fez carne, foi identificada como fator de unidade temática do discurso. A sequência dos motivos, também, evidenciou os esforços do autor para comunicar, de forma unitária, aos seus leitores a verdade da identidade de Jesus, o Filho de Deus, enviado ao mundo, para revelar o Pai. Essa atribuição da filiação divina de Jesus levou em conta o ambiente do cristianismo judeu no qual se firmava a ideia da revelação de Deus e de suas obras na criação pela "Palavra préexistente", que vindo ao mundo desvendava seu próprio mistério. Essa PalavraSabedoria era o apanágio de Israel (cf. Sir 24,1-23; Pr 8,22-31; Sb 7-9). Agora ao "fazer-se carne" e vindo morar entre os homens, manifestou sua glória, dando à comunidade cristã a razão de sua fé (cf. Jo 1,14).

Não menos importante é a forma como o evangelista repetidamente escreve; é produto não apenas da teologia, mas da experiência da fé cristã que passa pelo "testemunho". O recurso às várias possibilidades de abordagem levou-o a cercar o leitor por todos os lados. E isso o levou a adotar a categoria do testemunho e a recorrer a inúmeros ensinamentos carregados de simbolismo, a fim de torná-los mais compreensíveis aos leitores que estava conduzindo.

A consideração do status do parceiro foi o elemento não linguístico a ser considerado (cap. VI). Por esse motivo, antes de se definir a temática do discurso, foi preciso identificar os interlocutores desse texto, o que tornou, cada vez mais 
evidente, a relação do texto narrativo com o discursivo. A importância da consideração do contexto literário mostrou que o sentido não está no texto, mas no que se constrói a partir dele, no curso de uma interação. O texto narrativo ofereceu ao discurso um preciso contexto espaço-temporal, permitindo prever seus leitores, o contexto situacional e, além disso, a necessidade de se fundamentar a origem da "Palavra" cheia de autoridade de Jesus que ordenara ao enfermo "levantar-se". A cura narrada em 5,8, em Jerusalém, no dia sábado, revelou a obra conjunta do trabalho do Pai e do Filho $(5,17)$, constituindo-se no foco da temática que deu unidade ao discurso de 5,19-47: "A Palavra de Jesus testemunha a unidade do Filho com o Pai”. Esta etapa contribuiu significativamente para que fosse organizada estrategicamente a comunicação que o autor queria fazer sobre a filiação divina de Jesus, por meio da linguagem da revelação pela Palavra préexistente. Essa função de contexto do discurso de 5,19-47, exercida pelo texto narrativo (5,1-18) é a chave para as relacionadas questões da presença de Jesus em Jerusalém e para a identificação da festa.

O discurso revelou um bom conhecimento da teologia e das normas dos escribas em torno do sábado, assim como das regras acerca dos testemunhos e dos escritos mosaicos. Esses motivos estão entremeados no discurso e seria muito difícil entendê-lo, se não se levasse em conta o pano de fundo rabínico, o que foi feito nessa fase. E mais ainda, no corpo do discurso há sentenças que têm que ser consideradas genuínas e pertencentes à tradição das palavras pronunciadas por Jesus. Em consequência, não é impossível que algumas partes desse discurso estejam solidamente fundadas nas controvérsias com os fariseus que formaram parte do ministério de Jesus, sem que a isso se oponha a possibilidade de que o evangelista dera a seu produto final uma ordenação e uma profundidade teológica que reflita uma visão posterior e mais madura. No discurso se detectam as três dimensões que fazem parte de toda a leitura do Evangelho de João: a referência à situação histórica, as referências às Escrituras e a referência à cristologia plenamente constituída e vivida na comunidade cristã.

Levando-se em conta que os Evangelhos não eram obras destinadas à leitura privada (entre outras razões, pela escassez e pelo custo dos livros manuscritos), mas principalmente à explicação e à reflexão comunitária, as alusões a textos do Antigo Testamento e certos sentidos figurados presentes na tradição semítica facilitavam a compreensão das perícopes. As declarações do discurso (e de todo o 
Novo Testamento) se referem ainda, em parte, às discussões intrajudaicas em torno da reta compreensão e da praxe certa da vontade de Deus. Em grande parte, porém essas declarações já são cristológicas, no sentido de transferirem para o Cristo, crucificado e ressuscitado, o simbolismo da Torá e sua função de caminho de salvação, bem como as funções de diversos papéis e figuras. Nela está a diferença decisiva entre o judaísmo e o cristianismo.

$\mathrm{Na}$ história foi-nos dado contemplar a glória, a manifestação do Deus distante em Jesus (cf. Jo 1,14). Manifestando-se como Filho, Jesus revelou uma relação especial e única com Deus (cf. 5,19-47). Essa relação continha a possibilidade de dar vida e de fazer julgamento (cf. 5,21-22). É aqui que essa relação adquire seu verdadeiro sentido histórico, pois as obras efetuadas por Jesus (cf. 5,$8 ; 11,43)$ não só levaram à sua identificação (cf. 5,17), como também, à ameaça de morte (cf. 5,18): sem o acento na realidade histórica de Jesus não se explicaria a rejeição histórica nem tampouco a interpretação teológica do Quarto Evangelho.

No centro da preocupação do autor está seu trabalho de dar à luz uma comunidade que estará em conformidade com aquela interpretação sobre Jesus, o I ogoj-Filho, que estava no seio do Pai, e, ao "fazer-se carne" $(1,14)$, veio revelar o mistério de Deus (cf. 1,18). Essa comunidade é portadora do testemunho e da confissão de fé na "encarnação do logg" (cf. 1,14), que se apresenta como a definitiva revelação de Deus na história. Os primeiros seguidores de Jesus esforçaram-se para encontrar imagens apropriadas para dizer quem era Jesus para eles mesmos e para os outros. O esforço deles foi um processo de autoenvolvimento, por ser, ao mesmo tempo, uma luta pela identidade de um movimento novo. O problema, no seu âmago, era um processo interpretativo: tanto no sentido amplo, de que o trabalho de formar uma identidade sempre envolve o mundo e o próprio ser dentro dele, quanto no sentido específico de que os textos sagrados e as tradições sobre seu significado estavam envolvidos. O padrão pelo qual tantos pontos na antiga religião judaica encontram seu cumprimento em Jesus está presente em várias referências que o autor faz às Escrituras (cf. 5,39. 47). A interpretação das Escrituras foi também um processo por meio do qual os seguidores de Jesus estavam tentando interpretar seu mundo, suas experiências, sua própria identidade. 
O Jesus-I ogoj põe o desafio de um contínuo processo interpretativo que não tem fim enquanto a Igreja e o mundo existirem. O círculo hermenêutico não consiste somente em olhar para trás, a escrutar a pré-história do texto. Ele obriga igualmente a olhar adiante, a seguir a vida do texto. Escrutar as raízes judaicas no Novo Testamento não é, com efeito, pôr vinho novo em odres velhos, mas é afirmar o realismo da encarnação (cf. Paulo em $\mathrm{Rm}$ 11,18: "é a raiz que te sustenta"). Evidentemente, nem sempre um cristão da primeira Igreja podia captar todas as alusões aos textos da Sagrada Escritura judaica, ou penetrar com facilidade os simbolismos; no entanto, familiarizados como se achavam com o modo de expressão próprio da época, poderiam compreendê-los e aceitá-los sem dificuldade, uma vez explicados. O leitor foi essencial ao processo interpretativo cristão.

A função da hermenêutica no processo de comunicação com um texto antigo é, particularmente, ter presente que os leitores reais de um texto antigo como os da Bíblia se diferenciam, de vez em quando, e que existe uma distância bem marcada entre os leitores originais para quem a obra foi escrita e aqueles, por exemplo, de nossa época. Não se trata só de distância temporal ou existencial, mas também cultural. Esta distância induz a exigir como os leitores de hoje possam instaurar um processo comunicativo com um autor que já está tão distante.

O estudo do texto de Jo 5,19-47 mostrou a importância do leitor para a compreensão do texto, conforme o autor quis que fosse entendido. O Evangelho de João tem um leitor implícito, pelo simples fato de ser um escrito narrativo, cujo objetivo foi guiar o leitor à confissão de fé que Jesus é o Cristo, o Filho de Deus (cf. 20,31). Ao final deste trabalho emerge a pergunta: Qual a relação que se estabelece entre o leitor implícito do texto e os leitores reais? Quem é o leitormodelo que o texto bíblico visa?

Toda a análise pragmalinguística indicou que a função do leitor-modelo, em nível literário, consiste em encarnar a "verdade" sedimentada no texto. Assim, o leitor real terá de traduzir na modalidade concreta de sua existência essa "verdade". Os leitores de todos os tempos - de diversas culturas, classes sociais e sensibilidade - são chamados constantemente a interagir com o leitor implícito delineado no texto e a configurar-se segundo os modelos que lhe são dados; não simplesmente copiando-os, mas repensando-os. É de todo evidente que, deste modo, a verdade representada do leitor-modelo não se esgotará em uma única 
atuação, mas assumirá modalidades diversas, segundo as circunstâncias: modalidade contida, todavia, na verdade do leitor-modelo representado na estratégia textual. O confronto entre o leitor-modelo e o leitor real deve levar à combinação em si das qualidades ideais de um leitor. Nesse caso o leitor empírico é obrigado a uma relação constante e verdadeira com aquele, participando das emoções provocadas pelo texto e, sobretudo, aprendendo a acolher o sistema de valores nele contido.

Diante de uma página bíblica, os leitores empíricos do século XXI entram em relação com a verdade do texto, comunicando-se com a figura do leitormodelo que encarna aquela "verdade". A verdade de uma mensagem bíblica repousa na veracidade da existência. O processo hermenêutico deve, portanto, evidenciar esta instância pragmática da palavra bíblica.

Segundo Massimo Grilli,

Se transportarmos tudo isto no campo hermenêutico, então, torna-se evidente que a verdade de um texto bíblico não vem plenamente percebida quando é traduzida simplesmente em esquemas "explicativos", mas quando se percebe a densidade "experiencial" e vem reportado ao âmbito da práxis. Um método deve sempre ser proporcional ao objeto; uma reta interpretação deve encontrar o ponto privilegiado a partir do qual a obra olha e interpreta a realidade. Ora, em relação ao que se refere ao texto bíblico, este ponto de vista não consiste em uma pura dimensão conceitual, e uma correta hermenêutica não pode ser fechada no freezer da pura exatidão teórica, porque a Bíblia não procura somente compreensão, mas obediência. Assim, a exegese bíblica recupera a sua dimensão hermenêutica e torna-se fonte de vida para o agir específico da comunidade ${ }^{598}$.

A abordagem comunicativa, visando analisar a força persuasiva do texto a partir de sua comunicação textual, ofereceu os meios para sua realização por considerar que é o texto em sua totalidade que oferece a cada elemento individualmente o horizonte em que deve ser compreendido. A partir da pragmalinguística a análise da rede de sequências do texto de Jo 5,19-47 se deteve nos estudos dos elementos da comunicação pertencentes à esfera do discurso, tendo como ponto central a análise do conteúdo do texto, o que permitiu constatar sua unidade literária e temática. A leitura do texto sob a ótica da pragamalinguística levou à conclusão da necessidade de se considerar, sobretudo, a figura do leitor como parte integrante do processo interpretativo.

598 Cf. GRILLI, M., artigo Pragmatica e analisi del texto. Disponível em: http:// www.evangeliumetcultura.org/IT/Pragmatica\%20e\%20analisi\%20del\%2Otesto.php Acessado em 14 de maio de 2012. 
O IV Evangelho é uma fonte aberta às possibilidades futuras de se aprofundar a construção da identidade cristã em sua relação de continuidade e descontinuidade com a fé judaica. A atenção ao judaísmo contemporâneo e ao Evangelho de João não permite que se veja esse Evangelho a partir de conflitos e polêmicas entre cristãos e judeus, mas como um diálogo com o judaísmo de sua época, do qual procediam os judeus cristãos da Sinagoga, e para resolver as dificuldades internas da própria comunidade cristã. Não se pode negar o caráter polêmico que se manifesta no Evangelho, mas se deve considerar que isso se explica, em parte, pelas diferentes tendências dentro da comunidade (expressas, posteriormente, nas três Cartas de João), e em parte, pelo caráter intransigente da cristologia da encarnação da Palavra de Deus $(1,14)$, no homem Jesus de Nazaré, o Filho de Deus (1,17-18). 


\section{8 \\ Referências bibliográficas}

8.1.

Bíblias e Documentos

A BÍBLIA. TEB. São Paulo: Paulinas/Loyola. 1995.

BÍBLIA DE JERUSALÉM. São Paulo: Paulus. 2002.

BÍBLIA HEBRAICA. $2^{a}$ Editio. Stuttgart: Deutsche Bibelgesellschaft. 1984.

BÍBLIA SACRA UTRIUSQUE TESTAMENTI. Editio Hebraica et Grega.

Stuttgart: Deutsche Bibelgesellschaft, 1994.

BÍBLIA SEPTUAGINTA. Id est Vetus Testamentum graece iuxta LXX interpretes Alfred Rahlfs. Stuttgart: Deutsche Bibelgesellschaft, 2004.

LA BIBLE. Paris: Desclée de Brouwer. 1985.

LA BIBBIA DI GERUSALEMME. Bologna: EDB. 2010.

NOVUM TESTAMENTUM GRAECE. 27 $7^{\mathrm{a}}$ Ed. Stuttgart: Deutsche Bibelge. 2001.

NUEVA BIBLIA ESPAÑOLA. Madrid: Ediciones Cristiandad. 1977.

O NOVO TESTAMENTO GREGO. $4^{\mathrm{a}}$ ed. Stutgart: Deutsche

Bibelgesellschaft; São Paulo: Sociedade Bíblica do Brasil. 2009.

PONTIFÍCIA COMISSÃO BÍBLICA. A Interpretação da Bíblia na Igreja. São Paulo: Paulinas. 1994.

\section{2.}

Dicionários, Comentários e Gramáticas

BAILLY, A. Le Grand Bailly. Dictionnaire Grec Français. Paris: Hachette. 2000.

BALZ, H.; SCHNEIDER, G. Diccionario Exegético del Nuevo Testamento.

Biblioteca de Estudos Biblicos 90. Salamanca: Sigueme. 1998. 2 v.

BAUER, J. B. Dicionário de Teologia Bíblica. São Paulo: Loyola. 1983. 2 v.

BEASLEY-MURRAY, G. R. Word Biblical Commentary. v. 36. $2^{\mathrm{a}}$ ed. Columbia: Thomas Nelson, Inc. 1999.

BERGANT, D.; KARRIS, R. Comentário Bíblico. São Paulo: Loyola. 1999. 3 v. 
BERLEJUNG, A.; FREVEL, C. (Orgs.). Dicionário de termos fundamentais do Antigo e do Novo Testamento. São Paulo: Loyola/Paulus. 2011.

BROWN, E. R.; FITZMYER, J. A.; MURPHY, R. E. Nuovo Grande Commentario Biblico. [S.I.]: Queriniana. 2002.

CEGAllA, D. P. Novíssima gramática da Língua Portuguesa. São Paulo: Editora Nacional. 1989.

CHARAUDEAU, P.; MAINGUENEAU, D. Dicionário de análise do discurso. São Paulo: Contexto. 2004.

CHEVAlIER, J.; GHEERBRANT, A. Dicionário de Símbolos. Rio de Janeiro: José Olympio. 2006.

CEREJA, W. R.; MAGALHÃES, T. C. Gramática, texto, reflexão e uso. São Paulo: Atual. 2012.

COENEN, L.; BROWN, C. Dicionário Internacional de Teologia do Novo Testamento. São Paulo: Vida Nova. 2000. 2 v.

CRAGHAN, J. Comentário Bíblico Internacional. Estella (Navarra): Verbo Divino. 2000.

DE VECCHI, P.; F. SACCHI. Verbi Greci. Milano: Edizione Bignami. 2002.

DUBOIS, J. (Org.). Dicionário de Linguística. São Paulo: Cultrix. 1993.

FREEDMAN, D. N. (Ed.). The Anchor Bible Dictionary. New York: Bantam Doubleday Dell Publishing Group. 1922.

FREIRE, A. Gramática grega. São Paulo: Livraria Amaral. 1982.

FRIBERG, B.; TIMOTHY. O Novo Testamento Grego Analítico. São Paulo: Vida Nova. 1987.

HARRIS, L. et al. Dicionário Internacional de Teologia do Antigo Testamento. São Paulo: Vida Nova, 1998.

JASTROW, M. Dictionary of the Targumim, Talmud Bavli, Talmud Yerushalmi and Midrashic Literature. USA: Treasury: Judaica. 2004.

JENNI, E.; WESTERMANN, C. Diccionário Teologico Manual del Antiguo Testamento. Madrid: Cristiandad. 1978. 2 v.

JOÜON, P. Grammaire de l'Hébreu Biblique. Rome: Editrice Pontificio Istituto Biblico. 1996.

KITTEL, G.; FRIEDRICH, G. (Orgs.). Grande Lessico del Nuovo Testamento.. Brescia: Paideia. 1966.

LÉON DUFOUR, X. Vocabulário de Teologia Bíblica. Petrópolis: Vozes. 1977. 
LEVORATTI, A. (Dir.). Comentário Bíblico LatinoAmericano. Nuevo Testamento. Estella (Navarra): Verbo Divino. 2003.

MONLOUBOU, L.; DU BUIT, F. M. Dicionário Bíblico Universal. Petrópolis: Vozes. 2003.

PEREIRA, I. Dicionário Grego-Português e Português-Grego. $6^{\mathrm{a}}$ Edição. Porto: Livraria Apostolado da Imprensa. 1984.

RIENECKER, F.; ROGERS, C. Chaves Linguísticas do Novo Testamento Grego. São Paulo: Vida Nova. 1995.

RUSCONI, C. Dicionário do Grego do Novo Testamento. São Paulo: Paulus, 2003.

SCHÖKEL, A. Dicionário Bíblico Hebraico-Português. $2^{\mathrm{a}}$ Ed. São Paulo: Paulus. 1997.

TARMON, A.; UVAL, E. Hebrew Verb Tables. Jerusalém: Tamir Publishers. 1998.

VAN DEN BORN (Org.). Dicionário Enciclopédico da Bíblia. Petrópolis: Vozes. 1977.

ZERWICK, M. Biblical Greek. Roma: Editrice Pontificio Istituto Biblico. 2005.

\section{3.}

Livros

ADAM, J.-M. Le Texte narratif: traité d'analyse textuelle des récits. Paris: PUF. 1994.

ALTER, R. The art of biblical narrative. New York: Pedermann. 1981. .; KERMODE, F. Guia literário da Bíblia. São Paulo: UNESP. 1997. ARISTÓTELES; HORÁCIO; LONGINO. A Poética clássica. Tradução direta do grego e do latim de Jaime Bruna. São Paulo: Cultrix. 2005.

ARMENGAUD, F. A pragmática. São Paulo: Parábola. 2006.

ARTOLA, M.; CARO SANCHEZ. Bíblia e Palavra de Deus. São Paulo: Ave Maria. 1996.

ASHTON, J. F. Compreendere il Quarto Vangelo. Città del Vaticano: Ed. Vaticana. 2000.

BARRET, C. K. El Evangelio según san Juan. Madrid: Cristiandad. 2003.

BARTHES, R. Elementos da semiologia. São Paulo: Cultrix. 2003. 
. et al. Análise estrutural da narrativa. Petrópolis: Vozes. 2011.

BAUCKHAM, R.; MOSSER, C. The Gospel of John and Christian theology.

Cambridge: Eerdmans Publishing. 2008.

BERGER, K. Hermenêutica do Novo Testamento. São Leopoldo: Sinodal. 1999.

BIDERMEN, M.-T. C. Teoria linguística: Leitura e crítica. São Paulo: Martins Fontes. 2001.

BLANCHARD, Y. São João. São Paulo: Paulinas. 2004.

BLANK, J. O Evangelho segundo João. v. 4/1b. Comentário e Mensagem. Petrópolis: Vozes. 1991.

BLINZLER J. Giovanni i Sinottici. Itália, Brescia: Paidéia. 1969.

BOISMARD, M. E.; LAMOUILLE. L'Évangile de Jean. Paris: Éditions du Cerf. 1978. $3 \mathrm{v}$.

BROWN, R. A Comunidade do Discípulo Amado. São Paulo: Paulinas. 1984. El Evangelio según san Juan. Madrid: Cristiandad. 1979. 2 v.

BULTMANN, R. The Gospel of John. A commentary. Oxford: [s.n.]. 1971.

CABA, J. Cristo, Pan de Vida. Teología Eucarística del IV Evangelio. Madrid: BAC. 1993.

CARREIRA NEVES, J. Escritos de São João. Lisboa: UCE. 2004.

CARSON, D. O Comentário de João. São Paulo: Shedd Publicações. 2007.

CASALEGNO, A. Para que contemplem a minha glória. Introdução à teologia do Evangelho de João. São Paulo: Loyol. 2009.

COLLIN, M.; LENHART, P. Evangelho e tradição de Israel. São Paulo: Paulus. 1994.

COTHENET, E. et al. Os Escritos de São João e a Epístola aos Hebreus. São Paulo: Paulinas. 1988.

CROATTO, S. Hermenêutica Bíblica. Para uma teoria da leitura como produção de significado. São Paulo: Paulinas/Sinodal. 1986.

CULPEPPER, A. R. Anatomy of the Fourth Gospel: A Study in Literary Design. Filadelfia: Fortress Press. 1987.

DESILVA, D. A. A Esperança da Glória. Reflexões sobre a honra e a interpretação do Novo Testamento. São Paulo: Paulinas, 2005.

DODD, C. H. Interpretación del Cuarto Evangelio. Madrid: Cristiandad, 2004. 
La Tradicion Histórica en el Cuarto Evangelio. Madrid: Cristiandad. 1978.

DUPREZ, A. Jésus et les dieux guérisseurs. A propós de Jean V. Paris: Gabalda. 1970 .

ECO, U. Lector in fabula. Coleção Estudos. São Paulo: Perspectiva. 2011.

EGGER, W. Lecturas del Nuevo Testamento. España (Navarra): Verbo Divino. 1990.

ÉPHREM DE NISIBE. Commentaire de L'Évangile Concordant ou Diatessaron. Tradução de Syriaque et de LArménian. Sources Chrétiennes 121. Paris: Les Éditions Du Cerf. 1966.

FABRIS, R.; MAGGIONE, B. Os Evangelhos. São Paulo: Loyola, 2006. 2 v.

FAUSTI, S. Una Comunità legge il Vangelo di Giovanni. Bologna-Milano: EDB-Ancora. 2008.

FERraro, G. Il Paraclito, Cristo, Il Padre nel Quarto Vangelo. Città del Vaticano: Editrice Vaticana. 1996.

O Espírito Santo no IV Evangelho. São Paulo: Loyola. 1982.

FEUILleT, A. O Prólogo do Quarto Evangelho. São Paulo: Paulinas. 1971.

FIORIN, J. L. Elementos da análise do discurso. São Paulo: Contexto. 2011.

FREY, J. Die Eschatologische Verkündigung in den Johanneischen Texten.

Die johanneische Eschatologie. III. Tübingen: Mohr/Siebeck. 2000.

GABEL, J. B.; WHEELER, C. B. A Bíblia como literatura. São Paulo: Loyola. 1993.

GANCHO, V. C. Como analizar narrativas. São Paulo: Ática. 2003.

GARCÍA-MORENO, A. Temas teológicos del Evangelio de San Juan. I. La Creación. Madrid: RIALP. 2007.

GARCIA-VIANA, L. F. El Quarto Evangelio: Historia, Teología y Relato. Madrid: San Pablo. 1997.

GHEZZI, E. Come abbiamo ascoltato Giovanni. Studio Esegetico-pastorale sul Quarto Vangelo. Bolonha: Digigraf. 2006.

GHIBERTI, G. Opera Giovannea. Torino: Elledici. 2003.

GILBERT, M.; ALETTI, J-N. A Sabedoria e Jesus Cristo. São Paulo: Paulinas. 1985.

GIROUD, J.-C.; PANIER, L. Semiótica, una prática de lectura y de análisis de los textos bíblicos. Estella: Verbo Divino. 1988. 
GOODMAN, P. The Structure of Literature. Chicago: University of Chicago Press. 1954.

GOPPELT, L. Teologia do Novo Testamento. Petrópolis: Sinodal/Vozes. 1983. 2 v.

GRASSO, S. Il Vangelo di Giovanni. Commento exegético e teológico. Roma: Città Nuova. 2008.

GUILDING, A. The Fourth Gospel and Jewish Worship. Oxford: The Clarendon Press. 1960.

GUILlET, J. Jesus Cristo no Evangelho de São João. São Paulo: Paulinas. 1985.

HAIGHT, R. Jesus, símbolo de Deus. São Paulo: Paulinas. 2003.

HARL, M. et al. A Bíblia Grega dos Setenta. S. Paulo: Loyola. 2007.

HEJELMSLEV, L. Prolegômenos a uma teoria da linguagem. São Paulo: Perspectiva. 2009.

HENGEL, M. La questione Giovannea. Brescia: Paideia. 1998.

HERMANS, M.; SAUVAGE, P. (Org.). Bíblia e História: Escritura, interpretação e ação no tempo. São Paulo: Loyola. 2006.

INFANTI, R. Le feste di Israele: nel Vangelo secondo Giovanni. Milano: San Paolo. 2010.

ISER, W. O Ato de leitura. Uma teoria do efeito estético. São Paulo: Ed. 34, 1996. 1999. $2 \mathrm{v}$.

JAUBERT, A. Leitura do Evangelho segundo João. São Paulo: Paulinas. 1982.

JEREMIAS, J. A Mensagem central do Novo Testamento. São Paulo: Paulinas. 1977.

Abba Jésus et son Père. Paris: Du Cerf. 1972.

JOÃO CRISÓSTOMO. Le Omelie su S. Giovanni Evangeliste. Torino: 1947.

JONGE, M. L'Évangile de Jean sources, rédaction, théologie. Belgique:

Leuven University Press. 1977.

KEENER, C. S. The Gospel of John. A Commentary. Massachussetts: Hendrickson Publishers. 2005. 2 v.

KELLNER, W. O Filho do Homem. A mensagem Político-teológica de Jesus. São Paulo: Paulinas. 1987.

KOCH, I. V. O texto e a construção de sentidos. São Paulo: Contexto. 2011. Desvendando os segredos do texto. São Paulo: Cortez. 2011. A coesão textual. São Paulo: Contexto. 2010. 
Introdução à linguística textual. São Paulo: Martins Fontes. 2009.

.; TRAVAGLIA, L. C. A coerência textual. São Paulo: Contexto. 2011.

KÖNINGS, J. Evangelho segundo João. Amor e fidelidade. Petrópolis:

Vozes/Sinodal. 2005.

KÜMMEL, G. Introdução ao Novo Testamento. São Paulo: Paulinas. 2009.

LAGRANGE, M.-J. Évangile selon Saint Jean. Paris: Lecoffre. 1966.

LÉON-DUFOUR, X. Leitura do Evangelho segundo João. São Paulo: Loyola. 1998. $4 \mathrm{v}$.

LIMA, C. L. (Org.). A literatura e o leitor. Textos de Estética da recepção. Rio de Janeiro: Paz e Terra. 2011.

LINDARS, B. The Gospel of John. London: Marshall, Morgan \& Scott. 1981.

LINGAD, C. G. JR. The Problems of Jewish Christians in the Joannine

Community. Roma: Editrice Pontificia Universitá Gregoriana. Série Teológica

73. 2001.

LOSADA F. A Literary Reading of John 5. Text as construction, Peter Lang. New York - Washington. 2000.

LUZARRAGA, J. El Evangelio de Juan en las Versiones Siríacas. Subsídia Bíblica, n. 33. Roma. 2008.

MAC DOWELL, J. A.; YAMAMOTO, M. Linguagem e linguagens. São Paulo: Loyola. 2005.

MACGREGOR, A. A estrutura do Quarto Evangelho. Londres: [s.i.]. 1961.

MACLEISH, K. Aristóteles. A poética de Aristóteles. São Paulo: UNESP. 2000.

MAIER, J. Entre os dois Testamentos. História e religião na época do Segundo Templo. São Paulo: Loyola. 2005.

MAINVILlE, O. (Org.). Escritos e ambiente do Novo Testamento. Petrópolis: Vozes. 2002.

A Bíblia à Luz da História. São Paulo: Paulinas. 1999.

MANNS, F. L'Évangile de Jean et la Sagesse. Studium Biblicum Franciscanum, 2003.

L'Évangile de Jean à la Lumière du Judaïsme. Studium Biblicum Franciscanum, 1991.

MARCHADOUR, A. L'Évangile de Jean. Commentaire pastoral. [s.n.]: Centurion. 1992. 
MARGUERAT, D. (Org.). Novo Testamento. História, Escritura e Teologia. São Paulo: Loyola. 2009.

. (Org). Primeira história do cristianismo - Os Atos dos Apóstolos.

São Paulo: Loyola. 2003.

.; BOURQUIN, Y. Para ler as narrativas bíblicas. São Paulo: Loyola. 2009.

MARTINI, C. O Evangelho segundo São João. São Paulo: Loyola. 1984.

MATEOS, J.; BARRETO, J. O Evangelho de São João. São Paulo: Paulinas. 1989.

; _ _ Vocabulário Teológico do Evangelho de João. São Paulo:

Paulinas. 1989.

.; CAMACHO, F. Evangelho. Figuras \& símbolos. São Paulo: Paulinas. 1992.

MAZIÈRE, F. A análise do Discurso. História e práticas. São Paulo: Parábola editorial. 2007.

MEEKS, W. Cristo é a questão. São Paulo: Paulus. 2007.

MEYNET, R. Chiamati Alla Libertà. Bologna: Centro Editoriale Dehoniano. 2010.

L'Analyse rhétorique. Une nouvelle métode pour comprendre la Bible. Paris: Du Cerf. 1989.

Retórica Bíblica e Semítica 1. Bologna: Centro Editoriale Dehoniano. 2008.

Tratado di Retórica Bíblica. Bologna: Centro Editoriale Dehoniano, 2008 .

MLAKUZHYL, G. The Christocentric Literary Structure of the Fourth Gospel. Roma: Pontificio Istituto Biblico. 1987.

MILITZ DA COSTA, L. A poética de Aristóteles. São Paulo: Ática. 2006.

MOLLONEY, J. F. Il Vangelo di Giovanni. Sacra Pagina. Torino: Elledici. 2007. Belief in the Word. Reading John 1-4. Minneapolis: Fortress Press. 1993.

MORA PAZ, C. et al. Lectura Pragmalingüística de la Bíblia. Teoría y aplicación. Estella (Navarra): Verbo Divino. 1999.

MORGEN, M. As Epístolas de João. São Paulo: Paulinas. 1979.

MOULE, C. F. D. As origens do Novo Testamento. São Paulo: Paulinas. 1979. 
NAY, R. Jahweh im Dialog. Kommunukationsanalytische Untersuchung von Ez 14,1-11 unter erücksichtigung des dialogischen Rahmens in Ez 8-11 und Ez 20. Roma: Pontificio Istituto Biblico. 1999.

OBARA, M. E. Le strategie di Dio. Dinamiche Comunicative nei Discorse Divini del Trito-Isaia. Roma: Pontificio Istituto Biblico. 2010.

OLIVEIRA, M. A. Reviravolta linguístico-pragmática na Filosofia contemporânea. São Paulo: Loyola. 1996.

PANIMOLLE, A. S. L'evangelista Giovanni. Pensiero e opera letteraria del Quarto Vangelo. Roma: Borla. 1985.

PELLETIER, A-M. Bíblia e hermenêutica hoje. São Paulo: Loyola. 2006.

PETIT, M. A arte de Ler ou como resistir à adversidade. São Paulo: Editora 34. 2010.

PROENÇA F. D. A linguagem literária. São Paulo: Ática. 2007.

PROPP, V. I. Morfologia do conto maravilhoso. Rio de Janeiro: Forense Universitária. 2010.

RATZINGER, J. Jesus de Nazaré. São Paulo: Planeta. 2011.

REUTER, Y. A análise da narrativa: O texto, a ficção e a narração. Rio de Janeiro: DIFEL. 2011.

REYES, G., La pragmática linguística. El estúdio del Uso del Lenguage Barcelona: Monte sinos. 1990.

RICOEUR, P. A hermenêutica bíblica. São Paulo: Loyola. 2006. A metáfora viva. São Paulo: Loyola. 2000.

RIGATO, M. L. Giovanni: L'enigma, Il Presbitero, Il culto, Il tempio, La Cristologia. Bolonha: EDB. 2007.

RIVA, F. L'Esegesi narrativa: Dimensioni Ermeneutiche. In Rivista Biblica. XXXVII. 1989. pp. 129-162.

ROLLAND, P., Présentation du Nouveau Testament selon l'ordre chronologique et la structure littéraire des écrits apostoliques. Paris: Ode Paris, 1995.

ROMANO DE SANT'ANNA, A. Paródia, paráfrase \& Cia. São Paulo: Ática, 2007.

SCHELKLE, H. Teologia do Novo Testamento. São Paulo: Loyola. 1977. 4 v. SCHNACKENBURG, R. El Evangelio según San Juan. Salamanca: Herder. 1980. $4 \mathrm{v}$. 
SCHÖKEL, A. A Palavra inspirada. São Paulo: Loyola. 1992. .; ASURMENDI, J. et al. A Bíblia em seu contexto. São Paulo: Ave Maria. 1994.

SCHREINER, J. Palavra e mensagem. São Paulo: Paulinas. 1978.

SCHREINER; DAUTZENGER. Forma e exigências do Novo Testamento. São Paulo: Paulinas. 1977.

SIMOENS, Y. Selon Jean: Une Traduction, Une Interpretation. Bruxelles: Institut d'Études Théologiques. 1997. 3 v.

SIMIAN-YOFRE, H. (Org.). Metodologia do Antigo Testamento. São Paulo: Loyola, 2000.

DA SILVA, C. M. et al. Metodologia da Exegese Bíblica. São Paulo: Paulinas. 2000 .

SKA, J. L. Our Fathers Have Told Us. Introducion to the Analysis of Hebrew Narratives. Subsidia biblica, n. 13. Roma. 2000.

SLOYAN, G. Giovanni. Torino: Claudiana. 2008.

SOARES, A. Gêneros literários. São Paulo: Ática, 2007.

STTIBE, M. W. G. John as Storyteller. Cambridge: Cambridge University Press. 1992.

TOSAUS, A. A Bíblia como literatura. Petrópolis: Vozes. 2000.

TREBOLlE, B. J. Bíblia Judaica e Bíblia Cristã. Petrópolis: Vozes. 1996.

TUÑI VANCELS O. J. Escritos Joanicos Y Cartas Católicas. Navarra: Verbo Divino. 1998.

O Testemunho do Evangelho de São João. Petrópolis: Vozes. 1989.

VANHOYE, A. Le don du Christ. Lecture Spirituelle. Paris: Les Compagnons Philosophiques. 2005.

VARGHESE, J. The Imagery of Love in the Gospel of John. Roma: Pontificio Istituto Biblico. 2009.

VERMES, G. A religião de Jesus, o Judeu. Rio de Janeiro: Imago. 1995.

VIDAL, S. Los escritos originales de la Comunidad del Discípulo Amigo de Jesus. Salamanca: Sigueme. 1997.

WEGNER, U. Exegese do Novo Testamento: Manual de Metodologia. São Paulo: Paulus/Sinodal. 2005.

WENGST, K. Il Vangelo di Giovanni. Brescia: Queriniana. 2005. 
ZABATIERO, J-P. T.; LEONEL, J. Bíblia, literatura e linguagem. São Paulo: Paulus. 2011.

ZIMMERMANN, H. Los Metodos Historicos-Críticos en El Nuevo Testamento. Madrid: B.A.C. 1969.

8.4.

Artigos

AMPHOUX, C-B. A propos de l'histoire du texte de Jean avant 300. Quelques lieux variants siginificatifs, In Lectio Divina n. 143. Paris: Cerf. 1990.

BORING, M. E. John 5:19-24 In Expository Articles. Interpretation n. 45. Texas: Texas Christian University. 1991. pp. 176-181.

BOWMAN, J. The Identity and date of the Unnamed Feast of John 5,1 In GOEDICKE, H.; ALBRIGHT W. I. Near Eastern Studies W. F. Albright. Baltimore. 1971. pp. 43-56.

CULPEPPER, A. R. Un exemple de commentaire fondé sur la critique narrative: Jean 5,1-18 In KAESTLI, J.-D.; POFFET, J.-M. ZUMSTEIN, J. (Eds.). La communauté johanique et son histoire. La trajectoire de l'évangile de Jean aux deux premiers siècles. Labor et Fides. Geneve. 1990. pp. 135-151.

DETTWILER, A. Fragile Compréhension. L'herméneutique de l'usage Johannique du malentendu In Revue de Théologie et de Philosofie n.131. 1999. pp. 367-384.

DODD, C. H. Une parabole cachée dans le quatriéme Évangile In Revue d'histoire et de philosophie religieuses 42. 1962. pp. 107-115.

DUPREZ, A. Probatique (piscine) In Supplément au Dictionaire de la Bible. v. 8. Paris: Letouzey. 1972. pp. 606-621.

GESCHÉ, A. Pour une identité narrative de Jésus In Revue Théologique de Louvain n. 30. 1999. pp. 153-179. pp. 336-356.

GROB. F. Mon Père travaille toujours. Jo 5,17 et la tradicion des logia de Jésus In RevSR n. 57. 1983. pp.19-27.

HAIGHT, R. Jesus como Cristo: O que está em jogo na Cristologia? In Concilium. n. $326-2008 / 3$. 
KAMMLER, H.-CHR. Christologie und Eschatologie. Joh 5,17-30 als Schlüsseltext johanneischer Theologie (WUNT 126), Tübingen: Mohr - Siebeck 2000 .

KÖNINGS, J. A Teologia como ciência e a Universidade Brasileira. In Perspectiva teológica, n. 108. 2007. pp. 243-250.

A Tradição do Discípulo Amado In Revista de Interpretação Bíblica Latino-Americana n. 17. 1994/1. p. 96.

LIEU, J. Narrative Analysis and Scripture in John. In MOYISE, S. (Ed.). The Old

Testement in the New Testement. Essays in Honour of J. L. North (Journal for the study of the New Testement. Supplement Series 189). Sheffield: Sheffield Academic Press. 2000. pp. 144-163.

MANNS, F. The historical character of the Fourth Gospel. In Liber Annuus n. 61. 2011. pp. 127-210.

MARGUERAT, D. L'Exégèse biblique: Éclatement ou Renouveau? In Foi et Vie. v. 93. n. 3. 1994. pp. 7-24.

L'Évangile de Jean et son lecteur. In CADIR. Le temps de la lecture: Exegese biblique et sémiotique. Paris: Cerf. 1993. pp. 305-324.

MEALAND D. L. John 5 and the Limits of Rhetorical Criticism In GRAEME, A. A. (Ed.). Understanding Poets and Prophets. Sheffield: JSOT Press. 1993. pp. 258-272.

MINETTE de TILLESSE. Os Quatro Evangelhos In Revista Bíblica Brasileira. Número especial 1-2-3. 2005.

MORETON, M. J. Feast, Sign and Discourse in John 5 In TU. n. 102. 1968. pp. 209-213.

NISSEN J., PEDERSON, S. (ed.). New Readings in John. Literary and Theological Perspectives: Essays from the Scandinavian Conference on the Fourth Gospel Arthus 1997. Sheffield: Sheffield Academic Press. 1999.

SIMIAN-YOFRE, H. Anacronia e sincronia: hermenêutica e pragmática. In SIMIAN-YOFRE, H. (Org.). Metodologia do Antigo Testamento. São Paulo: Loyola, 2000.

THACHER, T. The Sabbth Trick: Unstable Irony in the Fourth Gospel. In JSNT n. 76,1999 . pp. $53-77$.

THOMAS, J-C. Stop sinning lest something worse come upon you, The man at the pool in John 5. In JSNT n. 59. 1995. pp. 3-20. 
TREBOLE BARREIRA, J. “Antiguo” y "Nuevo" Testamento. Las identidades judía y cristiana: líneas de continuidad y de divergência. In Rivista Biblica n. 2. 2012. pp. 161-188.

URICCHIO, N. La teoria delle transposizioni nel Vangelo di S. Giovanni. In Biblica, n. 31, 1950, pp. 129-163.

VAN DEN BUSSCHE, H. Guérison d'un paralytique à Jérusalém. Le jour du sabbat. Jean 5,1-18 In BVC. n. 61. 1965. pp.18-28.

VANHOYE A. La composicion de Jn 5,19-30 In DESCHAMPS, A.; HALLEUX, A. (Ed.). Mélanges Bibliques. En hommage au R. Béda Riguax. Gembloux: Duculot. 1970. pp. 250-274.

VON WAHLDE U. C. He Has Given to the Son to have life in himself (John 5,26). In Bib. n. 85. 2004. pp.409-412.

. The Witnesses to Jesus in John 5,31-40 and Belief in the Fourth Gospel In CBQ. n. 43. 1981. pp. 385-404.

ZUMSTEIN, J. Lecture narratologique du cycle pascal du Quatrième Evangile. In Études Théologiques et Religieuses. Tomo 76. 2001/1. pp. 1-15.

ZUMSTEIN, J. L'apprentissage de la foi. À la découverte de l'Évangile de Jean et de ses lecteurs. Aubonne: Éd. du Moulin. 1993.

- (Ed.). La Communauté Johanique et son Histoire. La trajectoire de l'évangile de Jean aux deux premiers siècles. In Labor et Fides. Geneve. 1990. pp. $135-151$.

\section{5.}

\section{Artigos Web}

GRILLI, M. Comunicação e pragmatica. Disponível em: http://www.evangeliumetcultura.org/IT/Comunicazione\%20e\%2Pragmatica. php. Acessado em 14 de maio de 2012.

GRILli, M. Pragmatica e analisi del testo. Disponível em: http://www.evangeliumetcultura.org/ IT/Pragmatica\%20e\%20analisi\%20del\%2Otesto.php Acessado em 14 de maio de 2012. 


\section{ANEXO}

\section{1.}

Tabela sobre a estrutura literária do discurso

\begin{tabular}{|l|l|l|}
\hline $\begin{array}{l}\text { 9.1.1. } \\
\text { Exegetas que consideram o discurso de Jo 5,1-47 dividido em duas } \\
\text { partes, embora, às vezes, os versículos iniciais não coincidam: }\end{array}$ \\
\hline a) R. Brown (1979, p. 421 e 433) & $5,16-30 ; 31-47$. & $\begin{array}{l}\text { Jesus e o sábado: A } \\
\text { atuação de Jesus no } \\
\text { sábado. }\end{array}$ \\
\hline b) D. Carson (2007, p. 248 e 260) & $5,16-30 ; 31-47$. & $\begin{array}{l}\text { O relacionamento de } \\
\text { Jesus com seu Pai; Os } \\
\text { testemunhos a respeito } \\
\text { de Jesus. }\end{array}$ \\
\hline $\begin{array}{l}\text { c) J. Mateus; J. Barreto, (1989, p. 243 } \\
\text { e 267) }\end{array}$ & $5,16-30 ; 5,31-47$. & $\begin{array}{l}\text { A obra de Jesus, obra } \\
\text { do Pai; Testemunhas } \\
\text { em favor de Jesus. }\end{array}$ \\
\hline d) A. Marchadour (1992, p. 93) & $5,17-30 ; 31-47$. & $\begin{array}{l}\text { Controvérsias com os } \\
\text { judeus: A apologia de } \\
\text { Jesus; justificação de } \\
\text { pelo testemunho. }\end{array}$ \\
\hline e) C. Keener (2005, p. 645-655) & $5,17-47 ; 17-30 ;$ & $\begin{array}{l}\text { O Pai autoriza o Filho; } \\
\text { fazendo a vontade do } \\
\text { Pai; Testemunhos em } \\
\text { favor de Jesus. }\end{array}$ \\
\hline f) S. Fausti (v. I, 2002, p. 114-123) & $5,19-30$ e 31-47. & $\begin{array}{l}\text { O Pai ama o Filho; Não } \\
\text { tendes em vós o amor } \\
\text { de Deus. }\end{array}$ \\
\hline g) A. Ghezzi (2006, p. 346 e 373) & $5,19-30 ; 31-47$. & $\begin{array}{l}\text { A obra do Filho; O } \\
\text { testemunho do Pai dá } \\
\text { credibilidade a Jesus. }\end{array}$ \\
\hline h) F. Molloney, (2007, p. 153-161) & $5,19-30 ; 31-47$. & $\begin{array}{l}\text { Vida e julgamento; } \\
\text { Testemunho e } \\
\text { acusação. }\end{array}$ \\
\hline i) G. Sloyan (2008, p. 109-112) & $5,19-29 ; 30-47$. & $\begin{array}{l}\text { O Filho vê a obra do } \\
\text { Pai; Testemunho. }\end{array}$ \\
\hline 165 e 171) & $5,19-30 ; 31-40$. & $\begin{array}{l}\text { O Filho recebe poder } \\
\text { de julgar; Os } \\
\text { testemunhos da missão } \\
\text { de Cristo. }\end{array}$ \\
\hline $\begin{array}{l}\text { comunidade diante das } \\
\text { acusações. }\end{array}$ \\
\hline
\end{tabular}




\begin{tabular}{|c|c|c|}
\hline $\begin{array}{l}\text { 1) Beasley-Murray (WBC, 1999, p. } \\
75-77 \text { ) }\end{array}$ & $5,19-30 ; 31-47$. & $\begin{array}{l}\text { Jesus doador da vida e } \\
\text { juíz; Testemunhos a } \\
\text { favor de Jesus em face } \\
\text { do judaísmo incrédulo. }\end{array}$ \\
\hline m) C. Dodd (1977, p. 424; 434) & $5,19-30 ; 31-47$ & $\begin{array}{l}\text { O Filho dá a vida a } \\
\text { quem quer; A perpétua } \\
\text { atividade de Deus. }\end{array}$ \\
\hline n) Garcia-Viana (1997, p. 129-131) & $5,19-30 ; 31-47$ & $\begin{array}{l}\text { As obras e o poder do } \\
\text { Filho; Os testemunhos } \\
\text { em favor de Jesus. }\end{array}$ \\
\hline o) Carreira das Neves (2004, p. 159) & $5,19-30 ; 5,31-47$ & $\begin{array}{l}\text { Jesus, Filho de Deus } \\
\text { como doador da vida; A } \\
\text { obra do Pai e do Filho. }\end{array}$ \\
\hline p) J. Könings3 (2005, p. 139-148) & $5,19-30 ; 31-47$. & $\begin{array}{l}\text { Missão e poder de } \\
\text { Jesus; Testemunho a } \\
\text { favor de Jesus. }\end{array}$ \\
\hline q) F. Manns, (2003, p. 144) & $5,19-30 ; 5,31-47$ & $\begin{array}{l}\text { O Filho na } \\
\text { dependência do Pai; O } \\
\text { testemunho. }\end{array}$ \\
\hline r) Léon Dufour (1996, p. 19; 33) & $5,19-47$ & $\begin{array}{l}\text { O mistério do Filho. } \\
\text { duas partes bem } \\
\text { articuladas } 19-30 \text { e } 31- \\
47 \text {, com um único tema }\end{array}$ \\
\hline $\begin{array}{l}\text { s) Zimmermann (p. 441) divide em } \\
\text { dois }\end{array}$ & $5,19-30$ e $31-47$ & \\
\hline t) J. Blank, (1991, p. 17 e 44) & $5,17-30 ; 31-47$ & $\begin{array}{l}\text { O dia do sábado } \\
\text { escatológico; } \\
\text { Testemunhas e } \\
\text { testemunho em favor de } \\
\text { Jesus. }\end{array}$ \\
\hline
\end{tabular}

\subsection{2. \\ Exegetas que consideram o discurso dividido em três partes}

\begin{tabular}{|c|c|c|}
\hline a) K. Wengst (2005, p. 207-221) & $\begin{array}{l}\text { 5,17-20; 5,21-30; } \\
31-47 .\end{array}$ & $\begin{array}{l}\text { A ação de Deus se } \\
\text { realiza na ação de } \\
\text { Jesus; O evento } \\
\text { escatológico do dom } \\
\text { da vida e do juízo; A } \\
\text { reivindicação de Jesus } \\
\text { possui legitimidade } \\
\text { nele próprio. }\end{array}$ \\
\hline b) S. Grasso (2008, p. 232)5 & $\begin{array}{l}5,19-30 ; 31-40 \\
41-47 .\end{array}$ & $\begin{array}{l}\text { A obra conjunta do } \\
\text { Filho e do Pai; Os } \\
\text { testemunhos; A } \\
\text { rejeição de seus } \\
\text { interlocutores. }\end{array}$ \\
\hline c) S. Panimolle, $(1985$, p. $53 ; 164)$ & $\begin{array}{l}5,19-30 ; 31-40 \\
41-47 .\end{array}$ & $\begin{array}{l}\text { O Filho de Deus igual } \\
\text { ao Pai; O apelo a } \\
\text { autorrevelação; } \\
\text { testemunha e prova de } \\
\text { sua divindade; Jesus } \\
\text { contesta e condena a }\end{array}$ \\
\hline
\end{tabular}




\begin{tabular}{|c|c|c|}
\hline & & $\begin{array}{l}\text { incredulidade dos } \\
\text { judeus. }\end{array}$ \\
\hline d) Y. Simoens ${ }^{1}(1997$, p. 245) & $\begin{array}{l}\text { 5,19-30; 31-40; } \\
41-47 \text {. }\end{array}$ & $\begin{array}{l}\text { O discurso do Filho; } \mathrm{O} \\
\text { veredito; } \mathrm{O} \text { testemunho } \\
\text { requisitório. }\end{array}$ \\
\hline
\end{tabular}

\begin{tabular}{|c|c|c|}
\hline \multicolumn{3}{|c|}{$\begin{array}{l}\text { 9.1.3. } \\
\text { Exegetas que consideram o discurso de } 5,1-47 \text { inconcluso, e sua } \\
\text { continuação lógica o texto de } 7,15-24 \text {, com variação quanto à sua } \\
\text { estrutura e temática }\end{array}$} \\
\hline $\begin{array}{l}\text { a) R. Schnackenburg (1980, p. 127- } \\
\text { 194) }\end{array}$ & $\begin{array}{l}5,16-30 ; 31-47 \\
7,15-24\end{array}$ & $\begin{array}{l}\text { A perseguição de } \\
\text { Jesus por parte dos } \\
\text { judeus e o discurso } \\
\text { sobre a plena faculdade } \\
\text { do Filho para vivificar } \\
\text { e julgar; Credibilidade } \\
\text { referendada pelo } \\
\text { testemunho de Deus; } \\
\text { Condenação incrédula } \\
\text { de Jesus pelos judeus. } \\
\end{array}$ \\
\hline b) J. Caba (1993, p. 36) & $5,17-30$ e $31-47$ & \\
\hline c) J. Zumstein (2009, p. 437-468) & $\begin{array}{l}\text { 5,19-30; 31-47; } \\
7,15-24\end{array}$ & \\
\hline d) S. Vidal (1997, p. 498) & $5,19-47 ; 7,15-24$ & $\begin{array}{l}\text { A autoridade do } \\
\text { emissário celeste. }\end{array}$ \\
\hline e) B. Lindars (1981, p. 218-233) & $\begin{array}{c}5,19-24 ; 25-29 \\
30-47+7,15-24\end{array}$ & $\begin{array}{l}\text { A autoridade de Jesus: } \\
\text { O Filho apresenta o } \\
\text { trabalho do Pai; a } \\
\text { vinda do julgamento; } \\
\text { A igualdade do } \\
\text { testemunho de Jesus } \\
\text { com Deus. }\end{array}$ \\
\hline
\end{tabular}

\footnotetext{
${ }^{1}$ A divisão constitui três grandes elementos de um processo, um rib.
} 


\begin{tabular}{|c|c|c|}
\hline \multicolumn{3}{|c|}{$\begin{array}{l}\text { 9.1.4. } \\
\text { Exegetas que consideram o discurso de } 5,1-47 \text {, uma unidade, mas } \\
\text { com alguma divergência quanto aos versículos iniciais e à temática } \\
\text { do discurso }\end{array}$} \\
\hline a) G. Mlakuzhyil (1987, p. 217) & $5,14-47$ & $\begin{array}{l}\text { A autoridade do Filho } \\
\text { e seu testemunho. }\end{array}$ \\
\hline b) C. Barret (2003, p. 389) & $5,19-47$ & Jesus e o Pai. \\
\hline c) Y-M. Blanchard (2004, p. 48) & $5,19-47$ & $\begin{array}{l}\text { Discurso explicativo } \\
\text { sobre a cura. }\end{array}$ \\
\hline d) G. Ghiberti (2003, p. 35) & $5,19-47$ & $\begin{array}{l}\text { Discurso apologético } \\
\text { com os judeus. }\end{array}$ \\
\hline e) A. Guilding (1960, p. 70) & & Do testemunho. \\
\hline f) G. Kümmel², (2009, p. 275-276) & $5,19-47$ & $\begin{array}{l}\text { A obra do Filho. O } \\
\text { poder do Filho de Deus } \\
(19-30) \text { e a } \\
\text { legitimidade do } \\
\text { Revelador }(5,31-47)\end{array}$ \\
\hline
\end{tabular}

\footnotetext{
${ }^{2}$ Ele diz que o discurso interrompe o tema sem aludir à reação dos ouvintes. Não comenta qual seja o tema e quanto ao texto de 5,19-47 apresenta duas temáticas, p. 441.
} 